\title{
Assessment of Metal Transport Into and Out of Terrace Reservoir, Conejos County, Colorado, April 1994 Through March 1995
}

by Sheryl Ferguson and Patrick Edelmann

U.S. GEOLOGICAL SURVEY

Water-Resources Investigations Report 96-4151

Prepared in cooperation with the

U.S. ENVIRONMENTAL PROTECTION AGENCY

Denver, Colorado

1996

Supersedes Interim Report Published in June 1996 


\section{U.S. DEPARTMENT OF THE INTERIOR \\ BRUCE BABBITT, Secretary}

U.S. GEOLOGICAL SURVEY

Gordon P. Eaton, Director

The use of firm, trade, and brand names in this report is for identification purposes only and does not constitute endorsement by the U.S. Geological Survey.

For additional information write to:

Copies of this report can be purchased from:

District Chief

U.S. Geological Survey

Box 25046, Mail Stop 415

Denver Federal Center

Denver, CO 80225-0046
U.S. Geological Survey

Branch of Information Services

Box 25286

Denver, CO 80225-0286 


\section{CONTENTS}

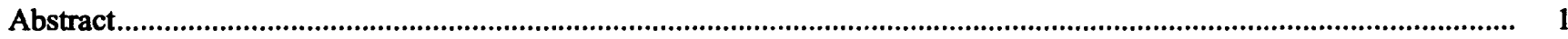

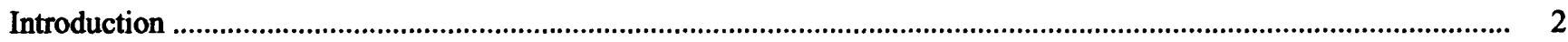

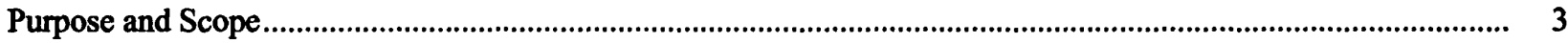

Water Quality of the Upper Alamosa River Basin ......................................................................................... 3

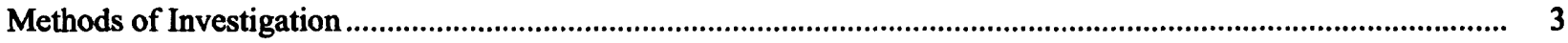

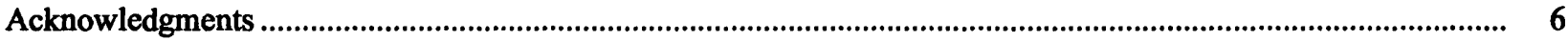

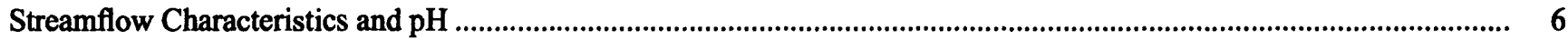

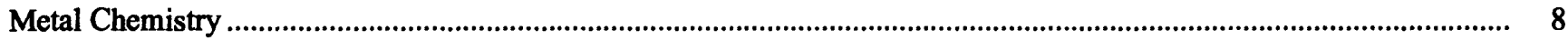

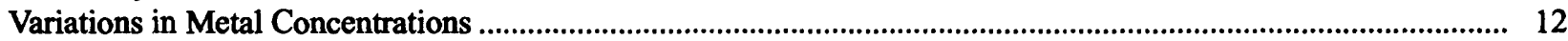

Percentage of Metals in the Dissolved and Suspended Fraction ......................................................................... 12

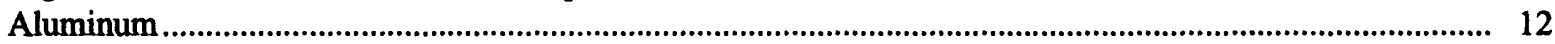

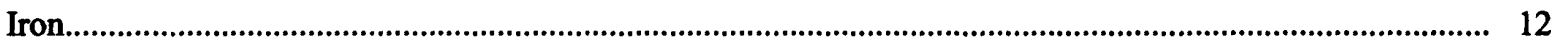

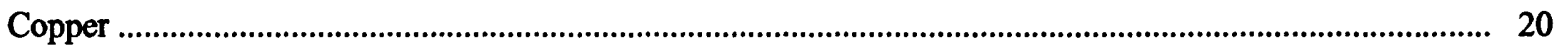

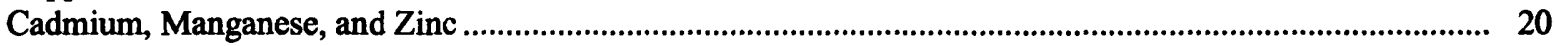

Correlations of Metal Concentrations, Streamflow, Specific Conductance, and pH........................................... 20

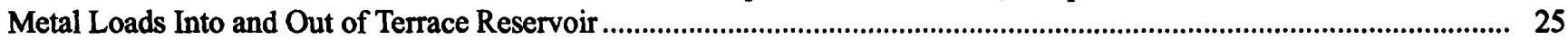

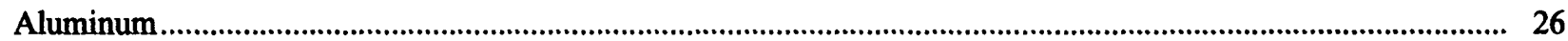

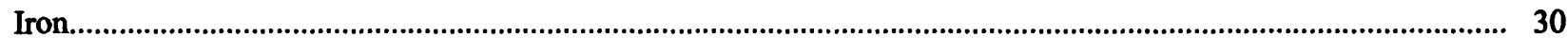

Copper

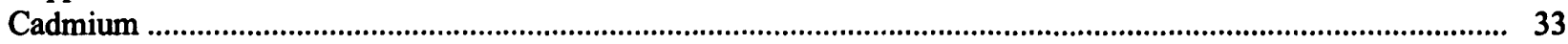

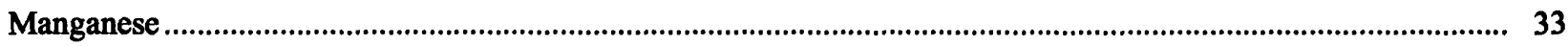

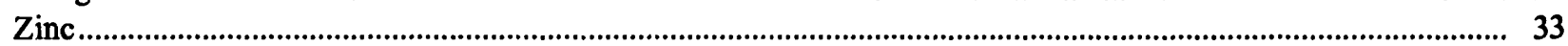

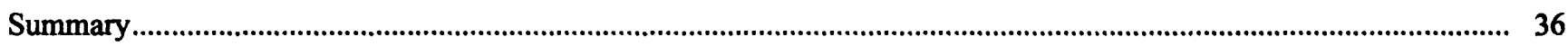

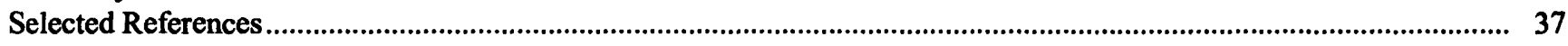

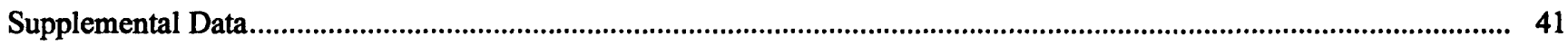

\section{FIGURES}

1. Map showing location of Terrace Reservoir and location of sampling sites upstream and downstream

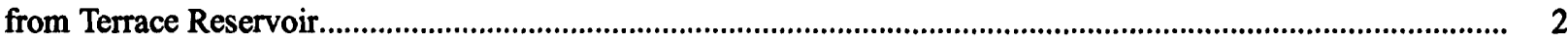

2. Streamflow hydrographs for sites AR34.5 and AR31.0, April 1994 through March 1995 ................................... 7

3. Graph showing instantaneous $\mathrm{pH}$ for sites AR34.5 and AR31.0, April 1994 through March 1995....................... 9

4-15. Graphs showing:

4. Dissolved- and total-aluminum concentrations for sites AR34.5 and AR31.0, April 1994 through March 1995.

5. Dissolved- and total-iron concentrations for sites AR34.5 and AR31.0, April 1994 through March 1995.

6. Dissolved- and total-copper concentrations for sites AR34.5 and AR31.0, April 1994 through March 1995.

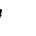
(1) 
11. Annual (A) and daily (B) total-aluminum loads into (site AR34.5) and out of (site AR31.0)

Terrace Reservoir, April 1994 through March 1995.

12. Annual (A) and daily (B) total-iron loads into (site AR34.5) and out of (site AR31.0)

Terrace Reservoir, April 1994 through March 1995.

13. Annual (A) and daily (B) total-copper loads into (site AR34.5) and out of (site AR31.0)

Terrace Reservoir, April 1994 through March 1995.

14. Annual (A) and daily (B) total-manganese loads into (site AR34.5) and out of (site AR31.0)

Terrace Reservoir, April 1994 through March 1995.

15. Annual (A) and daily (B) total-zinc loads into (site AR34.5) and out of (site AR31.0)

Terrace Reservoir, April 1994 through March 1995.

\section{TABLES}

1. Sample dates and analyses for sites AR34.5 and AR31.0, April 1994 through March 1995

2. Statistical summary of water-quality data for sites AR34.5 and AR31.0, April 1994 through

March 1995

3. Correlations of metal concentrations to streamflow, specific conductance, and $\mathrm{pH}$ for site AR34.5,

April 1994 through March 1995

4. Correlations of metal concentrations to streamflow, specific conductance, and $\mathrm{pH}$ for site AR31.0, April 1994 through March1995

5. Estimates of dissolved- and total-metal loads for sites AR34.5 and AR31.0, April 1994 through March 1995

6. Estimated daily dissolved-metal loads and standard errors for sites AR34.5 and AR31.0, April 1994 through March 1995

7. Estimated daily total-metal loads and standard errors for sites AR34.5 and AR31.0, April 1994

through March 1995.

\section{CONVERSION FACTORS AND VERTICAL DATUM}

\begin{tabular}{rll}
\hline Multiply & \multicolumn{1}{c}{ By } & To obtain \\
\hline cubic foot per second $\left(\mathrm{ft}^{3} / \mathrm{s}\right)$ & 0.02832 & cubic meter per second \\
foot $(\mathrm{ft})$ & 0.3048 & meter \\
mile $(\mathrm{mi})$ & 1.609 & kilometer \\
pound $(\mathrm{lb})$ & 0.4536 & kilogram \\
ton, short & 0.9072 & megagram \\
& & \\
\hline
\end{tabular}

The following terms and abbreviations also are used in this report:

milligram per liter $(\mathrm{mg} / \mathrm{L})$

micrometer $(\mu \mathrm{m})$

Sea level: In this report, "sea level" refers to the National Geodetic Vertical Datum of 1929 (NGVD of 1929)-a geodetic datum derived from a general adjustment of the first-order level nets of both the United States and Canada, formerly called Sea Level Datum of 1929. 


\title{
Assessment of Metal Transport Into and Out of Terrace Reservoir, Conejos County, Colorado, April 1994 Through March 1995
}

\author{
By Sheryl Ferguson and Patrick Edelmann
}

\begin{abstract}
Terrace Reservoir is the primary source of water for crops and livestock in the southwestern part of the San Luis Valley in southern Colorado. Mining activities have occurred in the basin for more than 100 years, and substantial mining of gold has occurred intermittently at the Summitville Mine. Historically, the Summitville Mine site has produced highly acidic, metalenriched water that drained from the mine site into Wightman Fork and flowed to the Alamosa River and Terrace Reservoir. In 1994, a study was begun as part of risk-assessment and remediation efforts and to evaluate metal transport into and out of Terrace Reservoir.

During the study period, the $\mathrm{pH}$ immediately upstream from Terrace Reservoir ranged from 4.3 to 7.8. The highest $\mathrm{pH}$ occurred during the pre-peak snowmelt period; the lowest $\mathrm{pH}$ occurred during storm runoff during summer. Downstream from Terrace Reservoir, the $\mathrm{pH}$ ranged from 4.6 to 7.6. The highest $\mathrm{pH}$ occurred during the pre-peak snowmelt period, and the lowest $\mathrm{pH}$ occurred during summer in mid-July. A comparison of the streamflow hydrographs upstream and downstream from Terrace Reservoir indicated that there was only a small difference between the annual volume of water that entered the reservoir and the annual volume of water that was released from the reservoir.

Large spatial and temporal variations in concentrations of the metals of concern occurred during the study. The median and maximum concentrations of dissolved and total aluminum, iron, copper, cadmium, manganese, and zinc were larger upstream from the reservoir than
\end{abstract}

downstream from the reservoir. The largest concentrations of dissolved aluminum, iron, copper, cadmium, manganese, and zinc generally occurred between mid-June and November.

Throughout the study, aluminum was transported into the reservoir predominantly in the particulate or suspended form. Downstream from the reservoir, the suspended-aluminum fraction was predominant only during the pre-peak snowmelt and peak snowmelt periods. The temporal variations in the percentage of dissolved and suspended fraction of iron and copper downstream from Terrace Reservoir were similar to the temporal variations that occurred upstream from the reservoir. During the study period, cadmium, manganese, and zinc generally were transported into and out of the reservoir predominantly in the dissolved form.

Metal loads varied considerably as a result of changes in streamflow or changes in metal concentrations, or both. The largest daily loads of aluminum, iron, and manganese were transported into and out of Terrace Reservoir during the peak snowmelt period. The reservoir was a sink for an estimated 294 tons of aluminum and 596 tons of iron. However, about 68.5 tons of total aluminum and about 194 tons of total iron were transported out of the reservoir during the study period. During the study period, about 22 tons of total copper remained in the reservoir, and 39 tons was transported downstream from the reservoir. About 47 tons of total manganese and 18 tons of total-zinc loads were transported out of the reservoir; the reservoir was a sink for only a small fraction of total-manganese and -zinc loads. 


\section{INTRODUCTION}

Terrace Reservoir is a small irrigation reservoir located on the Alamosa River at an elevation of about 8,550 ft above sea level in the San Juan Mountains in Conejos County, Colorado (fig. 1). The Alamosa River and Terrace Reservoir are the primary sources of water for crops and livestock in the southwestern part of the San Luis Valley. Irrigation ponds filled with Alamosa River water are stocked with fish for private use. The Alamosa River is important to the local economy and is a substantial component of the agricultural community (Posey and others, 1995).

Much of the drainage basin upstream from Terrace Reservoir contains extensive areas of mineralized rocks that in some places have been mined and that contribute a substantial metal load to the Alamosa River and Terrace Reservoir. Gold, silver, copper, and lead have been mined in the basin for more than 100 years, and extensive goldmining activities have occurred intermittently at the Summitville Mine (fig. 1) from 1873 to 1894, from 1926 to 1942, and from 1986 to 1992

(U.S. Environmental Protection Agency, 1993).

In December 1992, the operator of the Summitville Mine declared bankruptcy. The U.S. Environmental Protection Agency immediately took over the Summitville Mine site under the U.S. Environmental Protection Agency Superfund Emergency Response authority. Preliminary ecological and human-health risk assessments indicated that concentrations of dissolved and total aluminum, cadmium, copper, iron, manganese, and zinc were large enough to be of environmental concern, and copper was determined to be the primary constituent of concern (Morrison and Knudsen Corporation and ICF Keiser Engineers, 1994).

As part of risk-assessment and remediation efforts, the U.S. Geological Survey began a study on Terrace Reservoir in 1994, in cooperation with the U.S. Environmental Protection Agency, to: (1) Evaluate metal transport into and out of the reservoir; (2) assess the physical and chemical characteristics of the reservoir, including an evaluation of the spatial and temporal distribution of metals in the

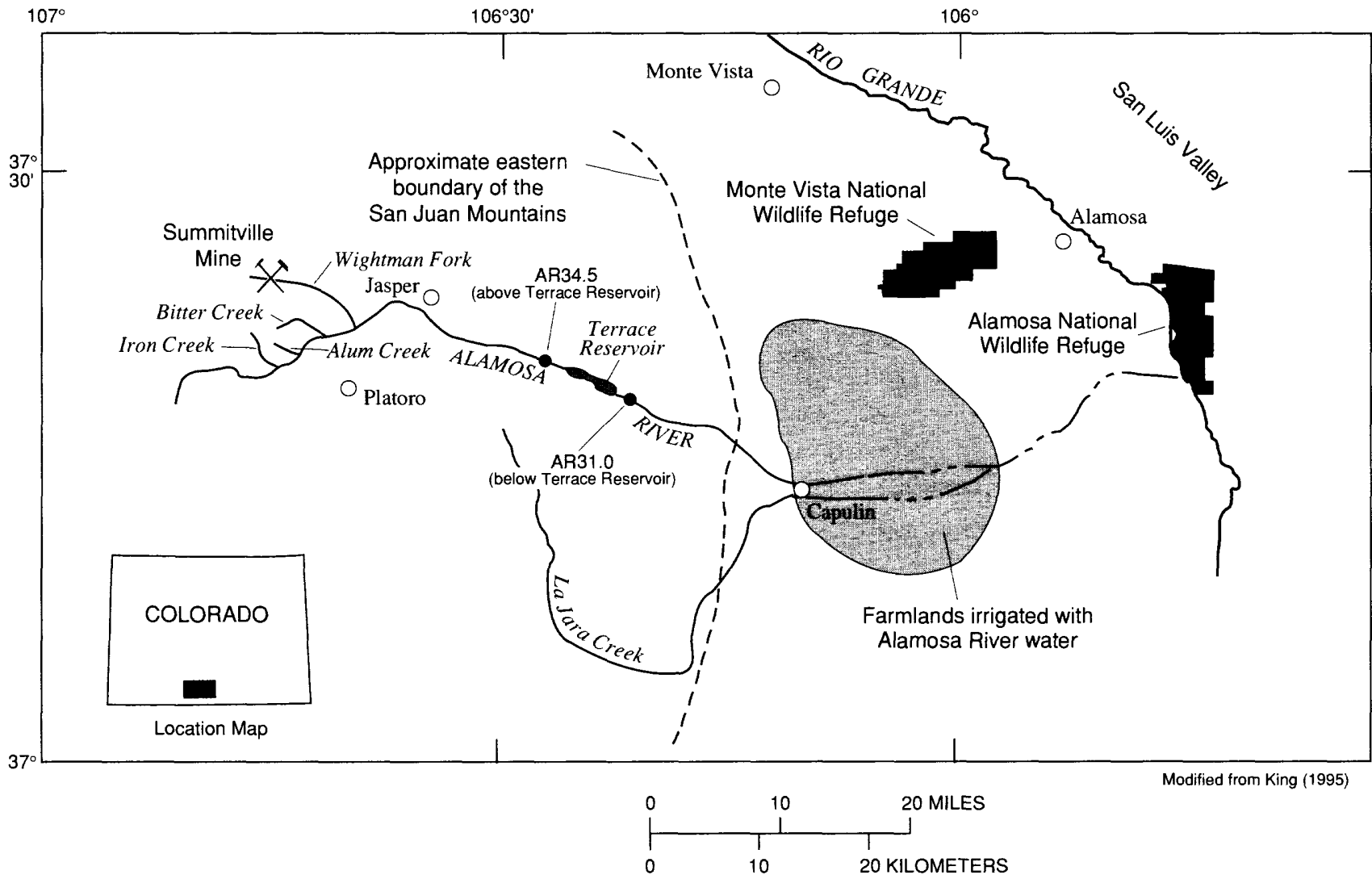

Figure 1. Location of Terrace Reservoir and location of sampling sites upstream and downstream from Terrace Reservoir. 
reservoir; (3) determine the mass of metals in the surficial reservoir sediments and the depth of metalenriched sediments; (4) evaluate the potential for remobilization of metals from the sediments; and (5) assess the exchange of metals between the sediments and the overlying water column.

\section{Purpose and Scope}

This report describes the metals transported into and out of Terrace Reservoir between April 1994 and March 1995. Specifically, it describes the spatial and temporal variations in metal concentrations in the Alamosa River immediately upstream and downstream from Terrace Reservoir and provides estimates of loads into and out of Terrace Reservoir during the study period. A summary of the percentage of dissolved-metal concentrations relative to totalmetal concentrations is presented; correlations of concentrations of the metals of concern, streamflow, specific conductance, and $\mathrm{pH}$ also are presented. The primary metals of concern in the Alamosa River were identified as aluminum, cadmium, copper, iron, manganese, and zinc (Morrison and Knudsen Corporation and ICF Keiser Engineers, 1994). Therefore, this report is limited to extensive discussion of these metals, but additionally provides a summary of concentrations for total arsenic, dissolved and total barium, dissolved and total cobalt, total lead, dissolved and total nickel, and total vanadium.

\section{Water Quallty of the Upper Alamosa River Basin}

From 1985 through 1992, the Summitville Mine site produced highly acidic, metal-enriched water that drained from the mine site into Wightman Fork and flowed to the Alamosa River and Terrace Reservoir (King, 1995). Acid drainage forms during chemical weathering when sulfide minerals react with water and oxygen to generate large amounts of sulfuric acid. Metals are released into solution when the sulfuric acid comes in contact with rocks, and heavy metals are leached out, resulting in water high in metal content and low in $\mathrm{pH}$. The Summitville Mine drainage water has been among the most acidic and metal-bearing water in Colorado; the drainage water has had a $\mathrm{pH}$ generally less than 3 and has contained high concentrations of aluminum, copper, iron, zinc, and other metals (King, 1995).
In addition to mining as a source of contamination, natural degradation of the water quality of the Alamosa River has occurred from tributaries and springs with low pH (Moran and Wentz, 1974; Hamilton, 1989; Miller and McHugh, 1994; Kirkham and others, 1995; Walton-Day and others, 1995). Previous studies of water quality indicated that Wightman Fork has been the predominant source of aluminum, copper, iron, manganese, and zinc during peak snowmelt and the post-peak snowmelt periods and has been the source of most of the copper, manganese, and zinc discharged annually into the Alamosa River (Walton-Day and others, 1995). Other metal-enriched sources downstream from Wightman Fork might include tributaries, material stored in the streambed, and ground water. The Alamosa River upstream from Iron Creek contains only moderate concentrations of iron and aluminum and very minor amounts of copper, zinc, and manganese (Walton-Day and others, 1995).

Water quality in the Alamosa River Basin is variable. The $\mathrm{pH}$ has varied from about 3.5 to greater than 7, hardness has varied from about 40 to almost $200 \mathrm{mg} / \mathrm{L}$, and the alkalinity generally has ranged from 2 to about $40 \mathrm{mg} / \mathrm{L}$ (Mueller and Mueller, 1995). During 1994, pH in Wightman Fork ranged from about 5 to 7.5 during the early spring snowmelt period, subsequently decreased to between 3.5 and 5 during the peak snowmelt period, and remained low throughout the summer and winter (Mueller and Mueller, 1995). During 1994, $\mathrm{pH}$ in the Alamosa River upstream from Wightman Fork ranged from 3.8 during the early spring snowmelt period to 7.5 during summer (Mueller and Mueller, 1995).

\section{Methods of Investlgation}

Two water-quality sampling sites, AR34.5 (station 08236000, Alamosa River above Terrace Reservoir) and AR31.0 (station 08236500, Alamosa River below Terrace Reservoir) were selected to describe the metal chemistry and to evaluate metal transport into and out of Terrace Reservoir (fig. 1). These sites were selected because of their proximity to the reservoir and because continuous streamflow data, which are required for load computations, are available for these sites. Both sites currently are operated as streamflow-gaging stations by the Colorado Division of Water Resources. The streamflow data used in this report were collected by the Colorado Division of Water Resources. 
Prior to collection of water-quality samples, all sampling equipment was thoroughly cleaned with a laboratory-grade detergent, rinsed sequentially with tap water, a dilute hydrochloric acid solution, and deionized water. The cleaned sampling equipment was placed into two clean, clear plastic bags between sampling events to avoid environmental contamination. Sampling equipment was thoroughly rinsed with river water prior to sampling. All personnel involved in sampling-equipment preparation and sample collection and processing wore latex gloves to minimize sample contamination.

Water-quality samples generally were collected using the equal-width increment method (Edwards and Glysson, 1988). The equal-width increment method provides a sample that is discharge weighted both vertically and laterally and whose volume is proportional to the discharge in the sampled zone. The equal-width increment method results in a representative constituent concentration for the entire river cross section. A US-DH-81 water-quality sampler was used when the river was wadable, and a US $-D-77$ water-quality sampler was used from the cableway when the river was not wadable (Edwards and Glysson, 1988). Both of these samplers use plastic components in their design; therefore, the potential of trace-element contamination resulting from sample contact with metal surfaces is minimized. After the samples were collected, aliquots of raw water for total or total-recoverable (whole-water) analyses were collected into a clean plastic bottle and acidified, using nitric acid, to a $\mathrm{pH}$ less than 2; additional aliquots were collected for dissolved-constituent analyses. These aliquots were filtered through a $0.45-\mu \mathrm{m}$ filter into a clean plastic bottle and acidified using nitric acid to a pH less than 2. After the samples were collected, preserved, and processed, the samples were sent using chain-of-custody procedures to a U.S. Environmental Protection Agency contract laboratory. The samples were analyzed for dissolved (filterable through $0.45-\mu \mathrm{m}$ filter) and total aluminum, antimony, arsenic, barium, beryllium, boron, cadmium, calcium, chromium, cobalt, copper, iron, lead, magnesium, manganese, mercury, molybdenum, nickel, potassium, selenium, silver, sodium, titanium, vanadium, and zinc by using either inductively coupled plasma (ICP) or graphite furnace atomic absorption (GFAA) methods.
Quality-control/quality-assurance samples represented about 10 percent of the total samples. These included replicate samples and equipment blanks. Quality-control/quality-assurance samples were analyzed for concentrations of dissolved and total metals. Results from quality-control sample analyses indicated that cleaning procedures were acceptable and that cross contamination was not a problem.

Transport of metals entering Terrace Reservoir was evaluated using data collected at site AR34.5, Alamosa River above Terrace Reservoir (fig. 1; table 1). From late April 1994 through March 1995, 52 water samples were collected at site AR34.5 for total-metal analyses, and 34 water samples were collected for dissolved-metal analyses. Because previous investigations (Ortiz and others, 1995) indicated that substantial metal transport occurred in the Alamosa River Basin during rainfall runoff, samples were collected using an automatic sampler at a single point within the river cross section at site AR34.5 during a few rainfall-runoff events (table 1). These samples were analyzed for total or total-recoverable (whole-water) concentration of trace elements. In general, discrete samples collected during a runoff event were flow weighted the following day into a single composite sample by using guidelines described by the U.S. Environmental Protection Agency (1991) so an event-mean concentration could be determined. Additionally, selected discrete samples collected during a few runoff events were analyzed separately to provide information on the variability of metal concentrations that occurs during a rainfall-runoff event. To relate the metal concentration of point samples to a concentration that is representative of the entire cross section, an additional 22 point samples were collected concurrently with equal-width increment samples collected at various streamflows.

Transport of metals out of Terrace Reservoir was evaluated using data collected at site AR31.0, Alamosa River below Terrace Reservoir (fig. 1; table 1). From late April 1994 through March 1995, 25 water samples were collected at site AR31.0 for dissolved- and total-metal analyses. Four samples collected from November 1994 through March 1995 were collected at this site during the period when the reservoir outlet was closed. 
Table 1. Sample dates and analyses for sites AR34.5 and AR31.0. April 1994 through March 1995

[X, sample collected and analyzed; --, no specific sample time because sample was composited from several discrete samples collected during a storm; NS, sample not analyzed for dissolved metals]

\begin{tabular}{|c|c|c|c|c|c|c|c|}
\hline $\begin{array}{c}\text { Sample } \\
\text { date }\end{array}$ & $\begin{array}{c}\text { Sample } \\
\text { time }\end{array}$ & $\begin{array}{c}\text { Total- } \\
\text { metal } \\
\text { analyses }\end{array}$ & $\begin{array}{c}\text { Dlssolved- } \\
\text { metal } \\
\text { analyses }\end{array}$ & $\begin{array}{l}\text { Sample } \\
\text { date }\end{array}$ & $\begin{array}{c}\text { Sample } \\
\text { time }\end{array}$ & $\begin{array}{c}\text { Total- } \\
\text { metal } \\
\text { analyses }\end{array}$ & $\begin{array}{c}\text { Dissolved- } \\
\text { metal } \\
\text { analyses }\end{array}$ \\
\hline \multicolumn{8}{|c|}{ SITE AR34.5 } \\
\hline \multicolumn{8}{|c|}{ Pre-peak snowmelt runoff: } \\
\hline $04 / 28 / 94$ & 1250 & $\mathbf{X}$ & $\mathbf{x}$ & $05 / 12 / 94$ & 1245 & $\mathrm{X}$ & $\mathbf{X}$ \\
\hline $05 / 05 / 94$ & 1320 & $\mathbf{X}$ & $\mathbf{x}$ & & & & \\
\hline \multicolumn{8}{|c|}{ Peak snowmelt runoff: } \\
\hline $05 / 17 / 94$ & 1255 & $\mathbf{X}$ & $\mathbf{X}$ & $05 / 26 / 94$ & 1030 & $\mathrm{X}$ & $\mathbf{X}$ \\
\hline $05 / 20 / 94$ & 0740 & $\mathbf{X}$ & $\mathbf{X}$ & $06 / 01 / 94$ & 1035 & $\mathbf{X}$ & $\mathbf{X}$ \\
\hline $05 / 24 / 94$ & 0835 & $\mathbf{X}$ & $\mathrm{X}$ & $06 / 02 / 94$ & 2345 & $\mathbf{X}$ & $\mathbf{X}$ \\
\hline \multicolumn{8}{|c|}{ Post-peak snowmelt runoff: } \\
\hline $06 / 09 / 94$ & 1340 & $\mathbf{X}$ & $\mathbf{X}$ & $06 / 27 / 94$ & 1320 & $\mathbf{X}$ & $\mathrm{X}$ \\
\hline $06 / 14 / 94$ & 1030 & $\mathrm{X}$ & $\mathrm{X}$ & $07 / 08 / 94$ & 1415 & $\mathrm{X}$ & $\mathrm{X}$ \\
\hline $06 / 22 / 94$ & 1355 & $\mathbf{x}$ & $\mathrm{X}$ & & & & \\
\hline \multicolumn{8}{|c|}{ Summer flow: } \\
\hline $07 / 20 / 94$ & 0825 & $\mathbf{X}$ & $\mathrm{X}$ & $08 / 26 / 94$ & 1000 & $\mathrm{X}$ & $\mathrm{X}$ \\
\hline $07 / 27 / 94$ & 1015 & $\mathbf{X}$ & $\mathrm{X}$ & $08 / 31 / 94$ & 1400 & $\mathrm{X}$ & $\mathbf{X}$ \\
\hline $08 / 02 / 94$ & 1105 & $\mathrm{X}$ & $\mathrm{X}$ & $09 / 09 / 94$ & 1240 & $\mathrm{X}$ & $\mathrm{X}$ \\
\hline $08 / 10 / 94$ & 1220 & $\mathbf{X}$ & $\mathbf{X}$ & $09 / 14 / 94$ & 1200 & $\mathrm{X}$ & $\mathrm{x}$ \\
\hline $08 / 15 / 94$ & 0930 & $\mathrm{X}$ & $\mathrm{X}$ & $09 / 26 / 94$ & 1415 & $\mathbf{X}$ & $\mathrm{x}$ \\
\hline \multicolumn{8}{|c|}{ Storm runoff: } \\
\hline $07 / 31 / 94$ & - & $\mathbf{X}$ & NS & $09 / 14 / 94$ & 0230 & $\mathbf{X}$ & NS \\
\hline $08 / 01 / 94$ & - & $\mathbf{x}$ & NS & $09 / 14 / 94$ & 0500 & $\mathbf{x}$ & NS \\
\hline $08 / 01 / 94$ & 1930 & $\mathbf{x}$ & NS & $09 / 14 / 94$ & 0800 & 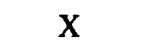 & NS \\
\hline $08 / 01 / 94$ & 2330 & $\mathbf{x}$ & NS & $09 / 14 / 94$ & 1301 & $\mathrm{X}$ & NS \\
\hline $08 / 02 / 94$ & 0530 & $\mathrm{x}$ & NS & $09 / 14 / 94$ & 1500 & $\mathrm{X}$ & NS \\
\hline $08 / 11 / 94$ & -- & $\mathrm{X}$ & NS & $09 / 14 / 94$ & 2100 & $\mathrm{X}$ & NS \\
\hline $08 / 14 / 94$ & -- & $\mathbf{x}$ & NS & $09 / 15 / 94$ & 0500 & $\mathrm{X}$ & NS \\
\hline $08 / 14 / 94$ & 2400 & $\mathrm{X}$ & NS & $09 / 15 / 94$ & - & $\mathrm{X}$ & NS \\
\hline $08 / 15 / 94$ & 2000 & $\mathrm{X}$ & NS & & & & \\
\hline $09 / 14 / 94$ & -- & $\mathrm{X}$ & NS & & & & \\
\hline \multicolumn{8}{|c|}{ Base flow: } \\
\hline $10 / 04 / 94$ & 1710 & $\mathbf{X}$ & $\mathbf{X}$ & $11 / 21 / 94$ & 1235 & $\mathrm{X}$ & $\mathrm{X}$ \\
\hline $10 / 12 / 94$ & 0945 & $\mathbf{X}$ & $\mathbf{x}$ & $11 / 21 / 94$ & 1330 & $\mathrm{X}$ & $\mathrm{X}$ \\
\hline $10 / 21 / 94$ & 1020 & $\mathrm{X}$ & $\mathbf{X}$ & $01 / 24 / 95$ & 1310 & $\mathrm{X}$ & $\mathrm{X}$ \\
\hline $10 / 26 / 94$ & 0855 & $\mathrm{X}$ & $\mathrm{X}$ & $02 / 22 / 95$ & 1630 & $\mathrm{X}$ & $\mathbf{X}$ \\
\hline $10 / 26 / 94$ & 0910 & $\mathrm{X}$ & $\mathbf{X}$ & $03 / 16 / 95$ & 0930 & $\mathrm{x}$ & $\mathrm{X}$ \\
\hline \multicolumn{8}{|c|}{ SITE AR31.0 } \\
\hline \multicolumn{8}{|c|}{ Pre-peak snowmelt runoff: } \\
\hline $04 / 28 / 94$ & 1440 & $\mathrm{X}$ & $\mathbf{x}$ & $05 / 12 / 94$ & 1220 & $\mathbf{x}$ & $\mathrm{X}$ \\
\hline $05 / 05 / 94$ & 1130 & $\mathbf{X}$ & $\mathbf{X}$ & & & & \\
\hline \multicolumn{8}{|c|}{ Peak snowmelt runoff: } \\
\hline $05 / 17 / 94$ & 1045 & $\mathbf{x}$ & $\mathbf{x}$ & $05 / 26 / 94$ & 1300 & $\mathbf{X}$ & $\mathbf{X}$ \\
\hline $05 / 20 / 94$ & 1025 & $\mathrm{X}$ & $\mathbf{X}$ & $06 / 01 / 94$ & 1330 & $\mathbf{X}$ & $\mathbf{X}$ \\
\hline $05 / 24 / 94$ & 1130 & $\mathrm{x}$ & $\mathbf{x}$ & & & & \\
\hline
\end{tabular}


Table 1. Sample dates and analyses for sites AR34.5 and AR31.0, April 1994 through March 1995-Continued

[X, sample collected and analyzed; --, no specific sample time because sample was composited from several discrete samples collected during a storm; NS, sample not analyzed for dissolved metals]

\begin{tabular}{|c|c|c|c|c|c|c|c|}
\hline $\begin{array}{c}\text { Sample } \\
\text { date }\end{array}$ & $\begin{array}{c}\text { Sample } \\
\text { tlme }\end{array}$ & $\begin{array}{c}\text { Total- } \\
\text { metal } \\
\text { analyses }\end{array}$ & $\begin{array}{l}\text { Dlssolved- } \\
\text { metal } \\
\text { analyses }\end{array}$ & $\begin{array}{l}\text { Sample } \\
\text { date }\end{array}$ & $\begin{array}{c}\text { Sample } \\
\text { tlme }\end{array}$ & $\begin{array}{c}\text { Total- } \\
\text { metal } \\
\text { analyses }\end{array}$ & $\begin{array}{l}\text { Dlssolved- } \\
\text { metal } \\
\text { analyses }\end{array}$ \\
\hline \multicolumn{8}{|c|}{ SITE AR31.0-Continued } \\
\hline \multicolumn{8}{|c|}{ Post-peak snowmelt runoff: } \\
\hline $06 / 09 / 94$ & 1020 & $\mathrm{X}$ & $\mathbf{X}$ & $06 / 22 / 94$ & 1005 & $X$ & $\mathrm{X}$ \\
\hline $06 / 16 / 94$ & 0710 & $\mathrm{X}$ & $\mathrm{X}$ & $06 / 27 / 94$ & 1440 & $\mathbf{X}$ & $\mathrm{X}$ \\
\hline \multicolumn{8}{|c|}{ Summer flow: } \\
\hline $07 / 21 / 94$ & 0915 & $\mathrm{X}$ & $\mathbf{X}$ & $08 / 26 / 94$ & 1200 & $\mathbf{X}$ & $\mathrm{X}$ \\
\hline 07/27/94 & 1425 & $\mathbf{X}$ & $\mathrm{X}$ & 09/09/94 & 0845 & $\mathbf{X}$ & $\mathrm{X}$ \\
\hline $08 / 10 / 94$ & 1005 & $\mathbf{X}$ & $\mathbf{X}$ & $09 / 26 / 94$ & 1600 & $\mathbf{x}$ & $\mathrm{X}$ \\
\hline $08 / 16 / 94$ & 0915 & $\mathrm{X}$ & $\mathbf{X}$ & & & & \\
\hline \multicolumn{8}{|c|}{ Base flow: } \\
\hline $10 / 12 / 94$ & 1120 & $\mathrm{x}$ & $\mathrm{x}$ & $01 / 24 / 95$ & 0930 & $\mathrm{X}$ & $\mathbf{X}$ \\
\hline $10 / 26 / 94$ & 1030 & $\mathrm{x}$ & $\mathrm{X}$ & $02 / 22 / 95$ & 1420 & $X$ & $\mathbf{X}$ \\
\hline $11 / 21 / 94$ & 1430 & $\mathbf{X}$ & $\mathbf{X}$ & $03 / 14 / 95$ & 1030 & $\mathbf{X}$ & $\mathrm{X}$ \\
\hline
\end{tabular}

Instantaneous streamflow, water-temperature, $\mathrm{pH}$, dissolved-oxygen, and specific-conductance data collected during the study are available from the U.S. Geological Survey; results of analyses of the metal and trace-element data collected during the study are available from the U.S. Environmental Protection Agency. The mean daily streamflow data used in this report are available from the Colorado Division of Water Resources.

\section{Acknowledgments}

The authors would like to express special thanks for the cooperation, interest, and support provided by James Hanley, U.S. Environmental Protection Agency, and by Harry H. Posey and James A. Pendleton, Colorado Department of Natural Resources, Division of Minerals and Geology. Thanks are extended to the following persons without whom the successful completion of this project would not have been possible: Craig Cotton, Colorado Division of Water Resources in Alamosa, Colorado, for providing streamflow data; and Roderick F. Ortiz, Charles M. Moore, Nicole Nelson, and Melinda Wright, U.S. Geological Survey, for data collection and processing.

\section{STREAMFLOW CHARACTERISTICS AND pH}

Streamflow in the upper Alamosa River Basin predominantly is derived from melting of snow that accumulates in the mountains between October and May. The largest streamflows occur between April and July during snowmelt runoff. Frequent summer rainstorms contribute substantially to summer flows. Downstream from Terrace Reservoir, streamflow is largely controlled by the quantity of water released from the reservoir to meet downstream irrigation demands. The streamflow hydrographs for the study period for sites AR34.5 and AR31.0 are shown in figure 2 . The annual streamflow hydrographs were divided into discrete flow periods. The flow periods were defined as follows: April 1, 1994, through April 14, 1994, was defined as the early spring snowmelt period; April 15, 1994, through May 14, 1994, was defined as the pre-peak snowmelt period; May 15, 1994, through June 8, 1994, was defined as the peak snowmelt period; June 9, 1994, through July 14, 1994, was defined as the post-peak snowmelt period; July 15, 1994, through September 30, 1994, was defined as the summer-flow and storm-runoff periods; and, upstream from the reservoir, October 1, 1994, through January 31 , 1995, was defined as the base-flow period. 


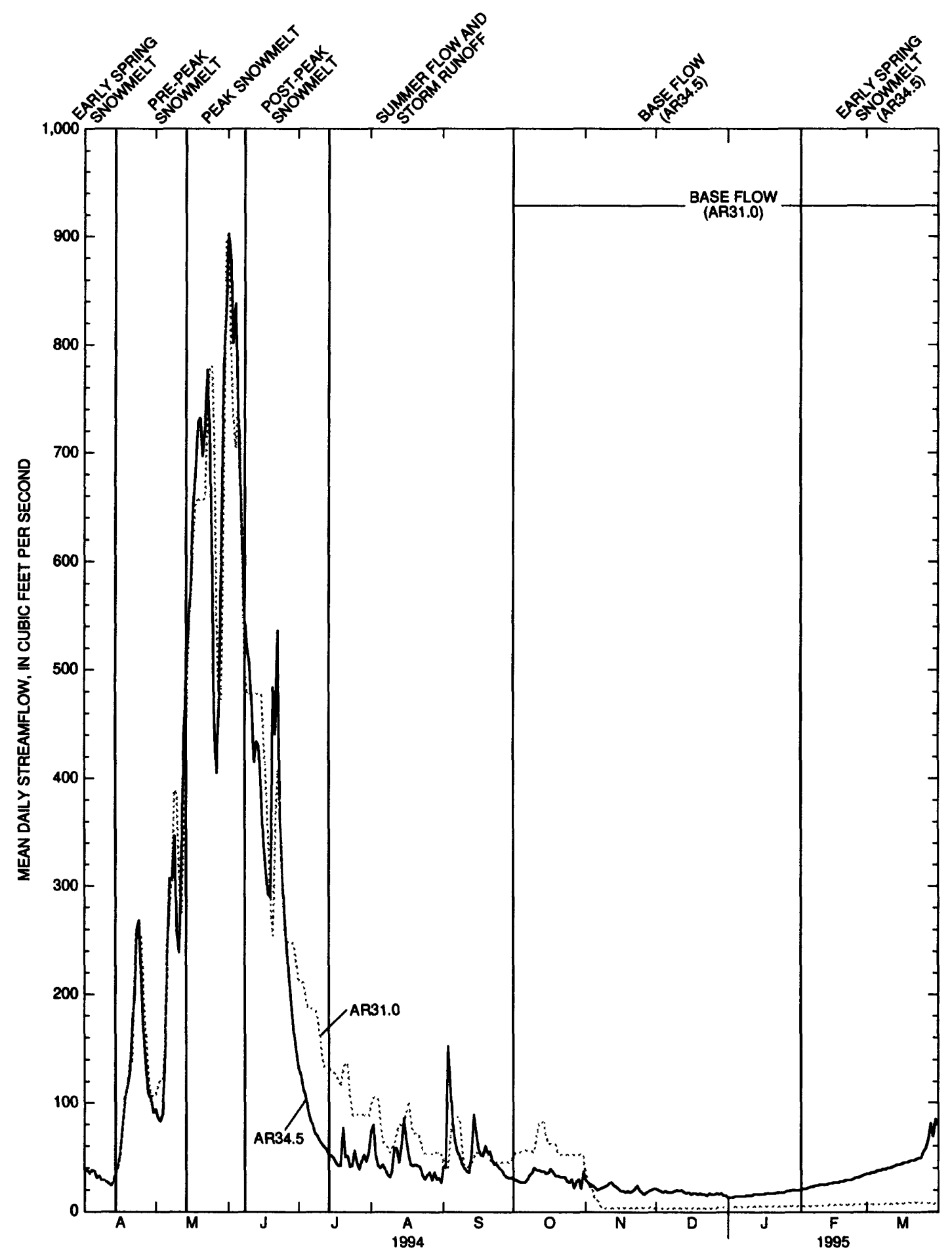

Figure 2. Streamflow hydrographs for sites AR34.5 and AR31.0, April 1994 through March 1995. 
Because the hydrograph at site AR34.5 showed a slight increase above the base flow from February 1, 1995, through March 31, 1995, this period was defined as the early spring snowmelt period upstream from the reservoir. Downstream from Terrace Reservoir, the entire period from October 1, 1994, through March 31, 1995, was defined as the base-flow period. These flow periods are used in describing the temporal variations in metal chemistry and metal loads.

A comparison of the streamflow hydrographs indicates that, from April 1 through June 8, 1994 (the early spring snowmelt, pre-peak snowmelt, and peak snowmelt periods), the volume of water released from Terrace Reservoir was within 5 percent of the volume of water that entered the reservoir. During the post-peak snowmelt period from June 9 through July 14, 1994, 14 percent more water was released from the reservoir than entered the reservoir due to downstream irrigation demand. During the summer period from July 15 through September 30, 1994, 31 percent more water was released from the reservoir than entered the reservoir due to downstream irrigation demand. As irrigation demand for water decreased and the reservoir outlet was closed in early November, water was stored in the reservoir during fall and winter. During the base-flow and early spring snowmelt periods from October 1, 1994, through March 31, 1995, 46 percent more water entered the reservoir than was released from the reservoir. Over the entire study period, there was only a minor difference between the volume of water that entered the reservoir and the volume of water that was released from the reservoir. Streamflow varies from year to year, depending on precipitation and temperature conditions in the upper basin. However, historical discharge data indicate that peak flow during the study period was consistent with amount and timing of streamflow in previous years.

Stogner and Edelmann (1996) indicated that reservoir residence times during periods of stratification generally were shortened by 40 to 75 percent of the theoretical (well-mixed) residence time. The shortest estimated residence times of 3 to 5 days occurred during late May to early June, a period corresponding to peak snowmelt runoff and strong thermal stratification. The short residence times during late May to early June are important in that they decrease the amount of time for physical or chemical processes to occur that might decrease concentrations of metals before water is released from the reservoir.

During the study period (April 1994 through March 1995), pH was measured concurrently with the collection of water-quality samples. The instantaneous $\mathrm{pH}$ measured at site AR34.5 (upstream from Terrace Reservoir) (fig. 1) ranged from 4.3 to 7.8 (fig. 3). The highest $\mathrm{pH}$ occurred during the pre-peak snowmelt period; the lowest $\mathrm{pH}$ occurred during storm runoff during the summer. At site AR31.0 (downstream from Terrace Reservoir) (fig. 1), $\mathrm{pH}$ ranged from 4.6 to 7.6. The highest pH occurred during the pre-peak snowmelt period, and the lowest $\mathrm{pH}$ occurred during summer in mid-July (fig. 3).

\section{METAL CHEMISTRY}

Preliminary ecological and human-health risk assessments indicated that concentrations of dissolved and total aluminum, cadmium, copper, iron, manganese, and zinc were large enough to be of environmental concern (Morrison and Knudsen Corporation and ICF Keiser Engineers, 1994). Therefore, the discussion of metal chemistry in this report is directed toward describing the variations that were measured at sites AR34.5 and AR31.0 for these metals. Water samples also were analyzed for dissolved and total arsenic, barium, chromium, cobalt, lead, mercury, nickel, selenium, silver, and vanadium. More than 90 percent of the samples analyzed for dissolved arsenic, lead, and vanadium and dissolved and total chromium, selenium, and silver had concentrations less than the analytical reporting level. Concentrations of total arsenic, dissolved and total barium, dissolved and total cobalt, total lead, dissolved and total nickel, and total vanadium measured in water samples collected at site AR34.5 generally were greater than the analytical reporting level (table 2), but were not considered to be of environmental concern. Therefore, only limited discussion of these data are included in this report. Samples collected for analysis of dissolved metals and trace elements were filtered through a $0.45-\mu \mathrm{m}$ filter. 


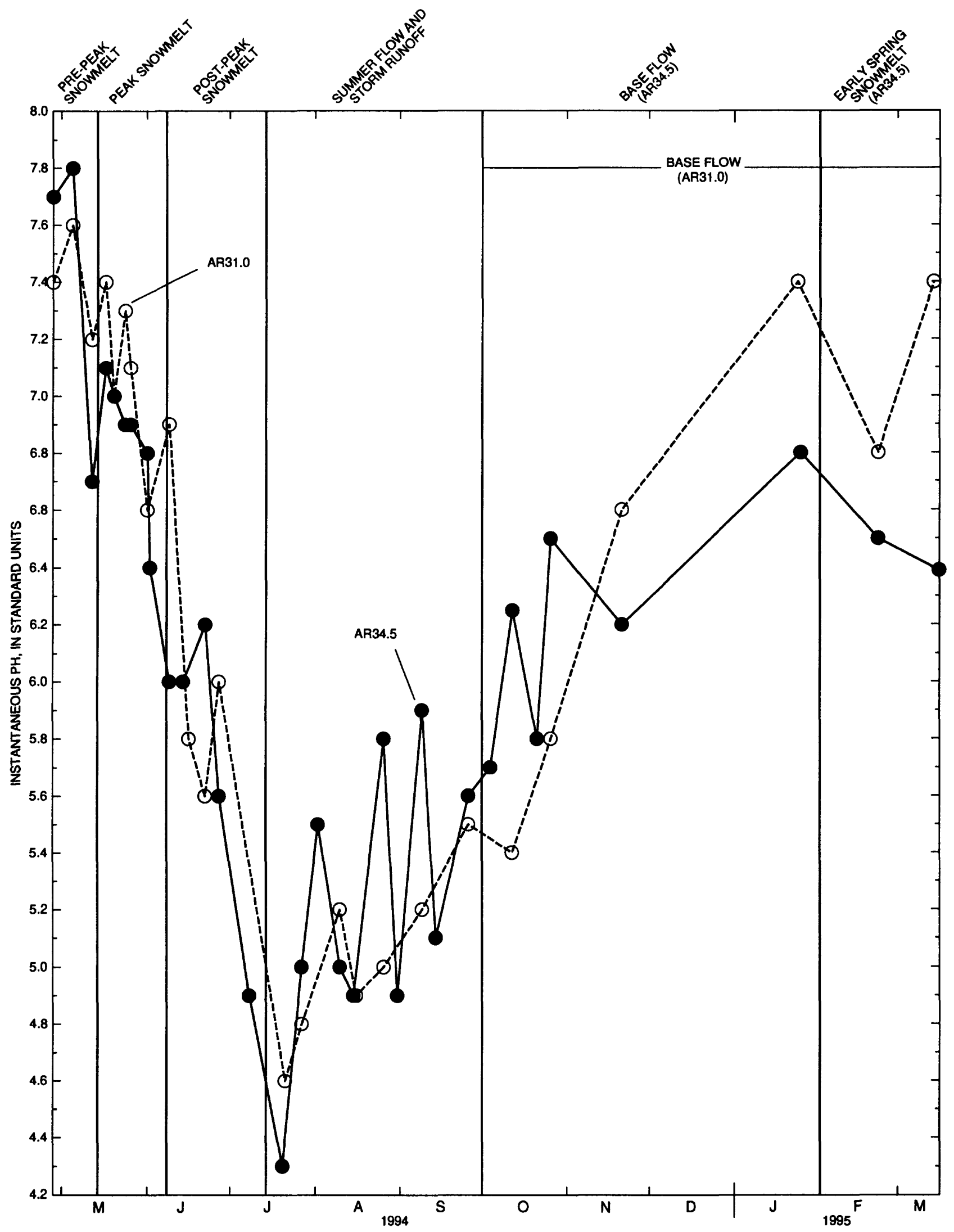

Flgure 3. Instantaneous pH for sites AR34.5 and AR31.0, April 1994 through March 1995. 
Table 2. Statistical summary of water-quality data for sites AR34.5 and AR31.0, April 1994 through March 1995

[Concentrations in micrograms per liter; <, less than; see fig. 1 for location of sites]

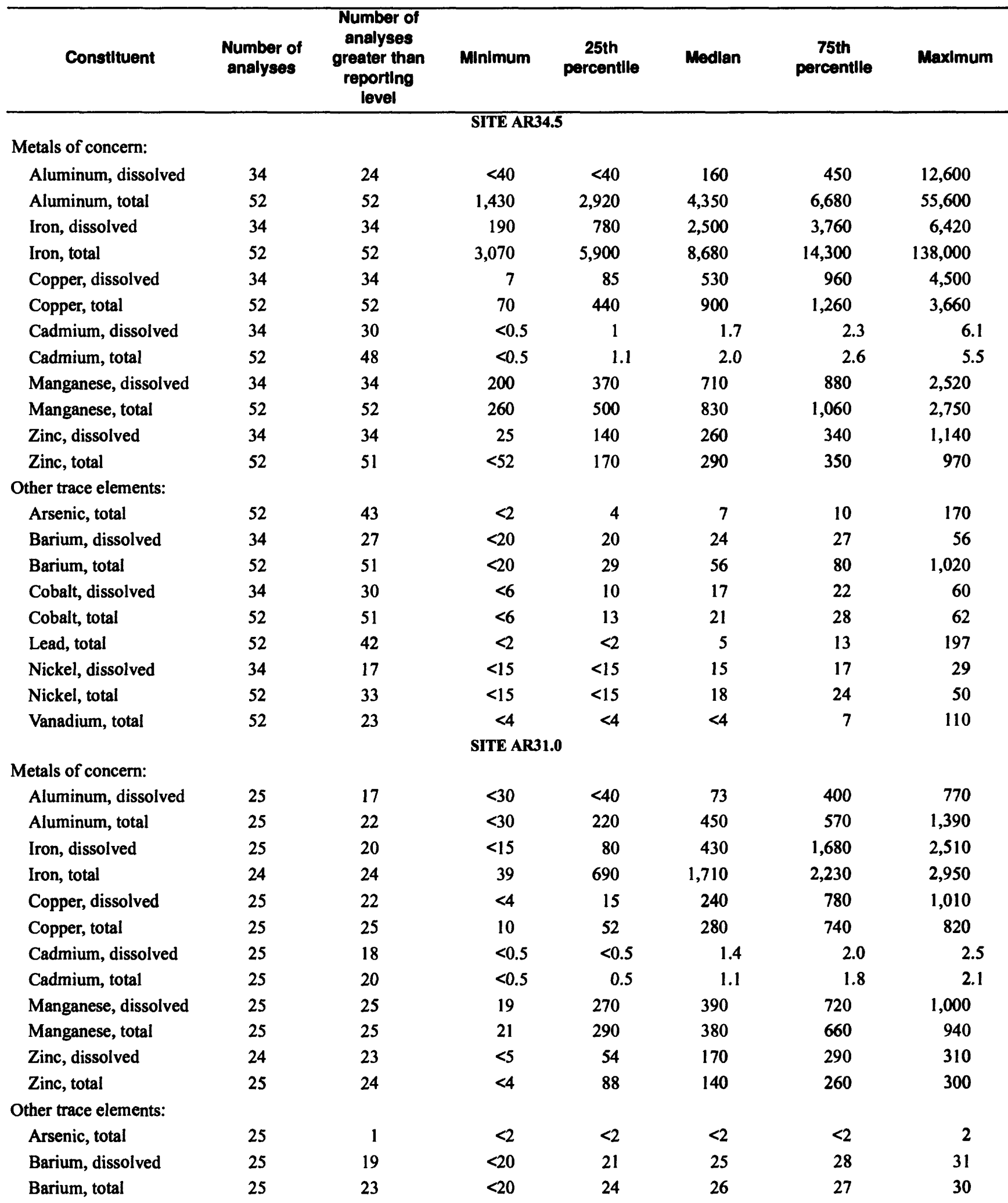


Table 2. Statistical summary of water-quality data for sites AR34.5 and AR31.0, April 1994 through March 1995-Continued [Concentrations in micrograms per liter; <, less than; see fig. 1 for location of sites]

\begin{tabular}{|c|c|c|c|c|c|c|c|}
\hline Constituent & $\begin{array}{c}\text { Number of } \\
\text { analyses }\end{array}$ & $\begin{array}{c}\text { Number of } \\
\text { analyses } \\
\text { greater than } \\
\text { reporting } \\
\text { level }\end{array}$ & Minimum & $\begin{array}{c}\text { 25th } \\
\text { percentlle }\end{array}$ & Medlan & $\begin{array}{c}\text { 75th } \\
\text { percentlle }\end{array}$ & Maximum \\
\hline \multicolumn{8}{|c|}{ SITE AR31.0-Continued } \\
\hline \multicolumn{8}{|c|}{ Other trace elements-Continued: } \\
\hline Cobalt, dissolved & 25 & 18 & $<5$ & $<6$ & 10 & 18 & 23 \\
\hline Cobalt, total & 25 & 18 & $<5$ & $<6$ & 11 & 16 & 21 \\
\hline Lead, total & 25 & 9 & $<2$ & $<2$ & $<2$ & $<2$ & 8 \\
\hline Nickel, dissolved & 25 & 8 & $<15$ & $<15$ & $<15$ & $<15$ & 19 \\
\hline Nickel, total & 25 & 6 & $<15$ & $<15$ & $<15$ & $<15$ & 23 \\
\hline Vanadium, total & 25 & 1 & $<3$ & $<4$ & $<4$ & $<4$ & 4 \\
\hline
\end{tabular}

This definition of "dissolved" is an operational one-only substances that pass through the filter are considered to be dissolved. However, numerous investigations of trace-element chemistry have indicated that water filtered through a $0.45-\mu \mathrm{m}$ filter can contain substantial amounts of colloidal trace elements (Kimball and others, 1995; Horowitz and others, 1996). Because colloids can pass through a $0.45-\mu \mathrm{m}$ filter, trace-metal concentrations reported as dissolved might include a substantial percentage of colloidal-size particles.

Comparisons of reported dissolved to reported total concentrations of aluminum, iron, copper, cadmium, manganese, and zinc indicated that reported dissolved-cadmium, -manganese, and -zinc concentrations frequently were greater than the reported total concentrations in samples collected from sites AR34.5 and AR31.0. Reported dissolved concentrations of aluminum were greater than reported total concentrations for samples collected from site AR31.0 during the summer-flow and storm-runoff period (July 15-September 30 ); reported dissolved concentrations of copper were greater than the reported total concentrations for samples collected from sites AR34.5 and AR31.0 during the summer-flow and storm-runoff period. Because dissolved-metal concentrations cannot be larger than total-metal concentrations, measurements of dissolved-metal concentrations that exceeded the total-metal concentrations resulted from either sampling and processing errors or laboratory uncertainties, or both. Laboratory personnel indicated that laboratory precision and accuracy of laboratory quality-control and quality-assurance samples were within 10 percent (Barbara Dabou, oral commun., 1996). In addition, field quality-control and qualityassurance samples indicated that no substantial contamination of environmental samples occurred during sample collection and processing, and analyses of replicate samples generally were within 10 percent. Further review of the data was unable to resolve the anomalies and resulted in some uncertainty in the reported metal concentrations. In general, the dissolved concentration was greater than the total concentration by less than 20 percent; the dissolvedand the total-metal concentration data were used to describe the metal chemistry and compute metal loads. However, the reader needs to be aware that uncertainty exists in the data and that the true error or uncertainty is unknown.

The metal chemistry section of this report describes the spatial and temporal variations in metal concentrations; the spatial and temporal variations in the percentage of metals that are in the dissolved and suspended fraction; and correlations of concentrations of metals of concern, streamflow, specific conductance, and $\mathrm{pH}$. 


\section{Variations in Metai Concentrations}

Large spatial and temporal variations in concentrations of the metals of concern occurred during the study. A statistical summary of metal concentrations upstream (at site AR34.5) and downstream (at site AR31.0) from Terrace Reservoir is listed in table 2. The statistics in this summary can be used to compare differences between dissolved and total metals at the same site and differences in metal concentrations upstream and downstream from Terrace Reservoir. The median and maximum concentrations of the metals of concern were larger upstream from the reservoir than downstream from the reservoir. Upstream and downstream from Terrace Reservoir, the largest concentrations of dissolved aluminum, iron, copper, cadmium, manganese, and zinc generally occurred between mid-June and November (figs. 4-9). Upstream from the reservoir (site AR34.5), the largest concentrations of total aluminum, iron, copper, cadmium, manganese, and zinc generally occurred between July and September during storm runoff. After November, dissolvedand total-metal concentrations generally decreased downstream from the reservoir after the closure of the reservoir outlet. Small increases in total-metals concentrations that occurred upstream from the reservoir in February and March may have been related to early spring snowmelt runoff.

\section{Percentage of Metals in the Dissoived and Suspended Fraction}

The percentage of the dissolved metal was computed by dividing the dissolved-metal concentration by the total-metal concentration and multiplying by 100 . The remainder is computed to be the suspended portion. The percentages are used to provide an indication of the dominant mode of metal transport into and out of Terrace Reservoir. Temporal variations were evaluated by dividing the annual streamflow hydrograph into the discrete flow periods as previously defined (fig. 2). The percentage of dissolved metals computed for samples collected during storm runoff at site AR34.5 are presented separately from other water-quality samples collected between July 15, 1994, through September 30, 1994, because the largest concentrations of total aluminum, iron, copper, cadmium, manganese, and zinc that occurred upstream from the reservoir generally occurred between July and September during storm runoff.

\section{Aluminum}

Throughout the study, aluminum was transported into the reservoir predominantly in the particulate or suspended form (fig. 10). More than 90 percent of the aluminum was in the suspended fraction during the pre-peak snowmelt, peak snowmelt, base-flow, and the early spring snowmelt periods. During the post-peak snowmelt, the summer-flow, and the storm-runoff periods, the percentage of dissolved aluminum increased slightly; however, the suspended-aluminum fraction still predominated.

Downstream from the reservoir, the suspended-aluminum fraction was predominant only during the pre-peak snowmelt and peak snowmelt periods. During the peak snowmelt period, when estimated reservoir residence times were between 3 and 5 days (Stogner and Edelmann, 1996), a large percentage of aluminum was transported out of Terrace Reservoir in the suspended fraction. After June 8 (the end of the peak snowmelt period), most of the aluminum that was transported out of Terrace Reservoir was in the dissolved fraction.

\section{Iron}

The temporal variations in the percentage of dissolved and suspended fraction of iron were similar upstream and downstream from Terrace Reservoir. During the pre-peak snowmelt and peak snowmelt periods, more than 90 percent of the iron was transported into and out of the reservoir in the suspended fraction (fig. 10). However, the percent dissolved-iron fraction generally was greater than 50 percent during the post-peak snowmelt and the summer-flow periods. The percentage of dissolved-iron fraction upstream from the reservoir decreased to about 25 percent during storm runoff, indicating that most of the iron transported into the reservoir during storm runoff was in the suspended fraction. During the baseflow and early spring snowmelt periods, most of the iron generally entered the reservoir in the suspended fraction. 

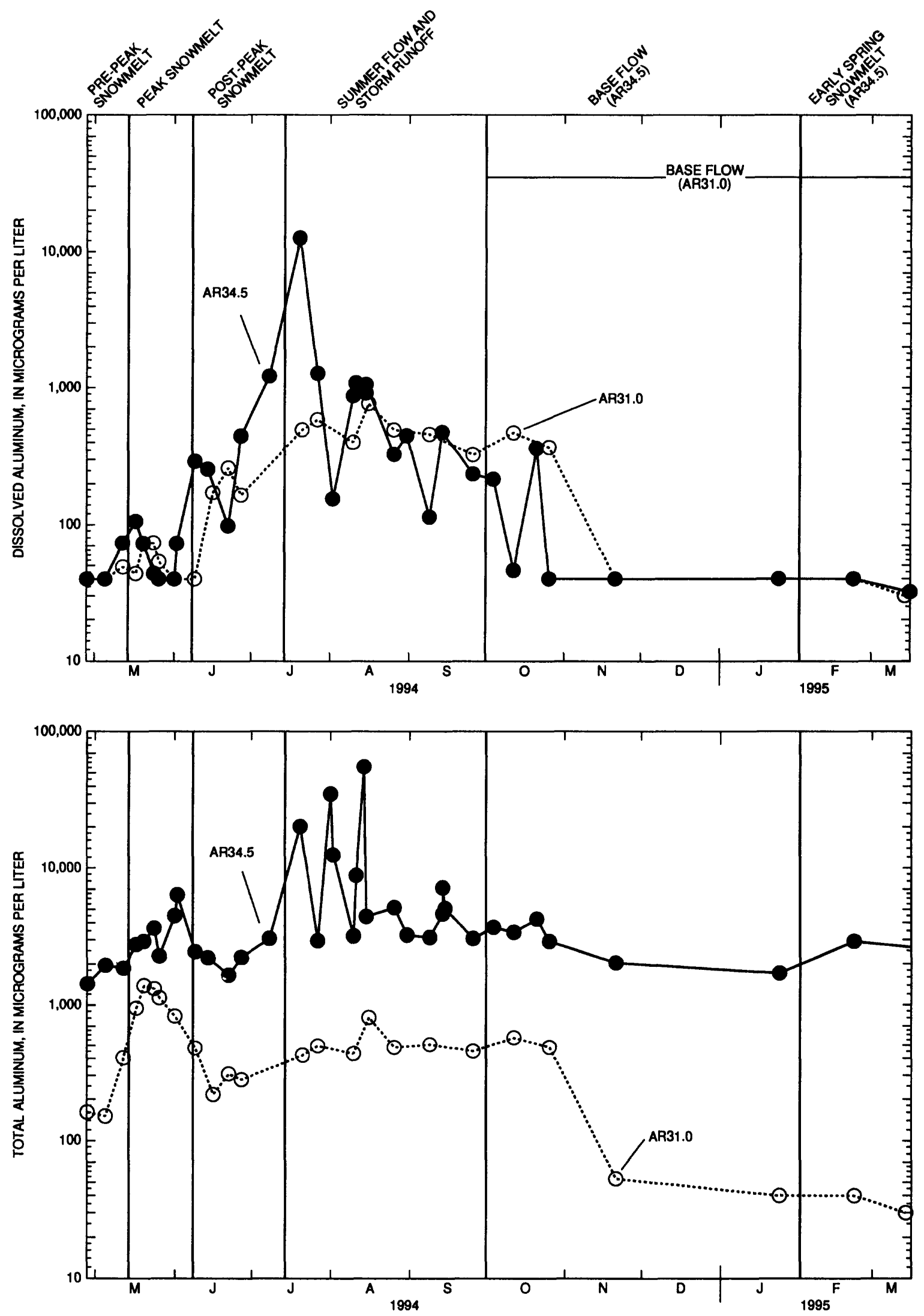

Figure 4. Dissolved- and total-aluminum concentrations for sites AR34.5 and AR31.0, April 1994 through March 1995. 

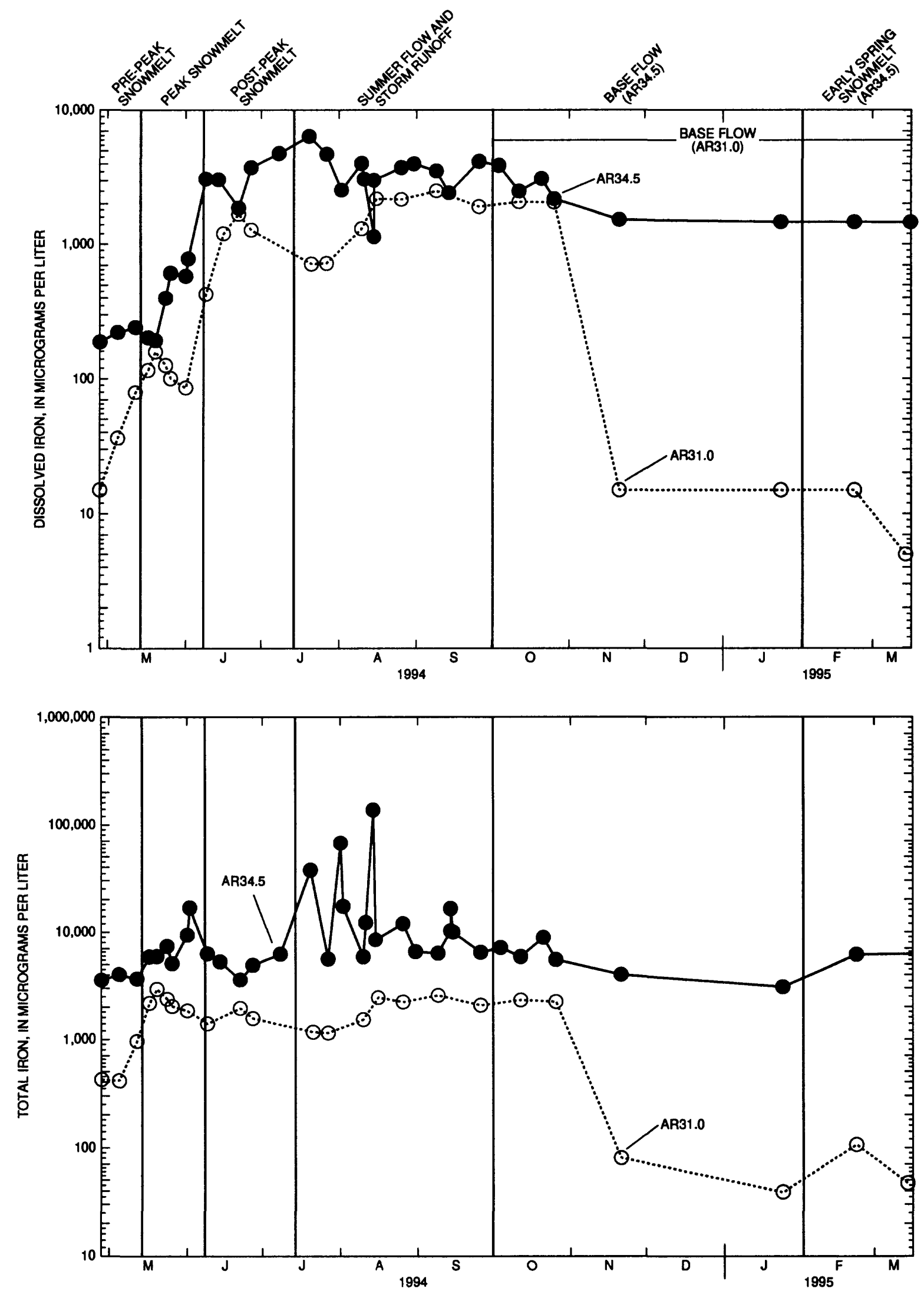

Flgure 5. Dissolved- and total-iron concentrations for sites AR34.5 and AR31.0, April 1994 through March 1995. 

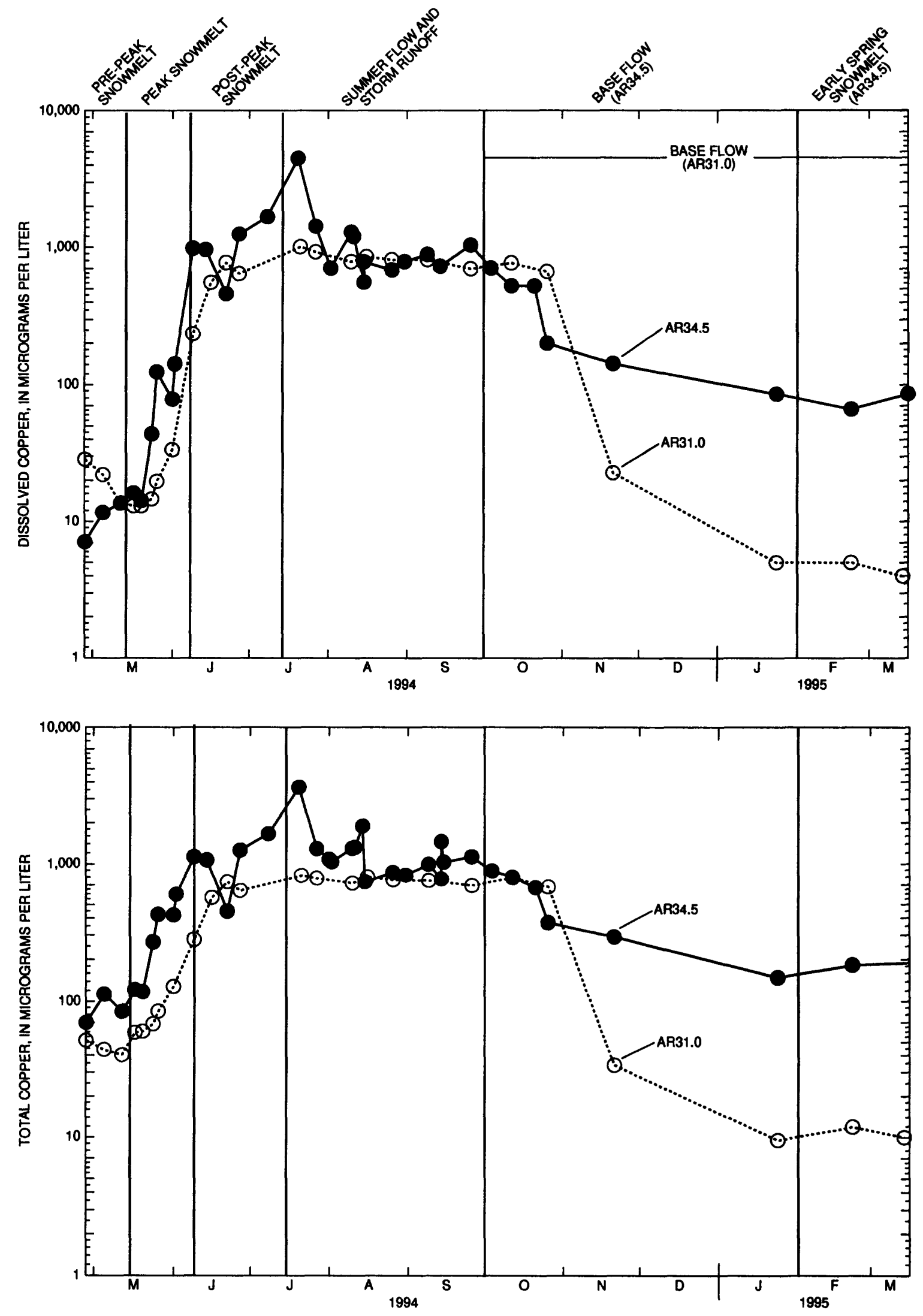

Figure 6. Dissolved- and total-copper concentrations for sites AR34.5 and AR31.0, April 1994 through March 1995. 

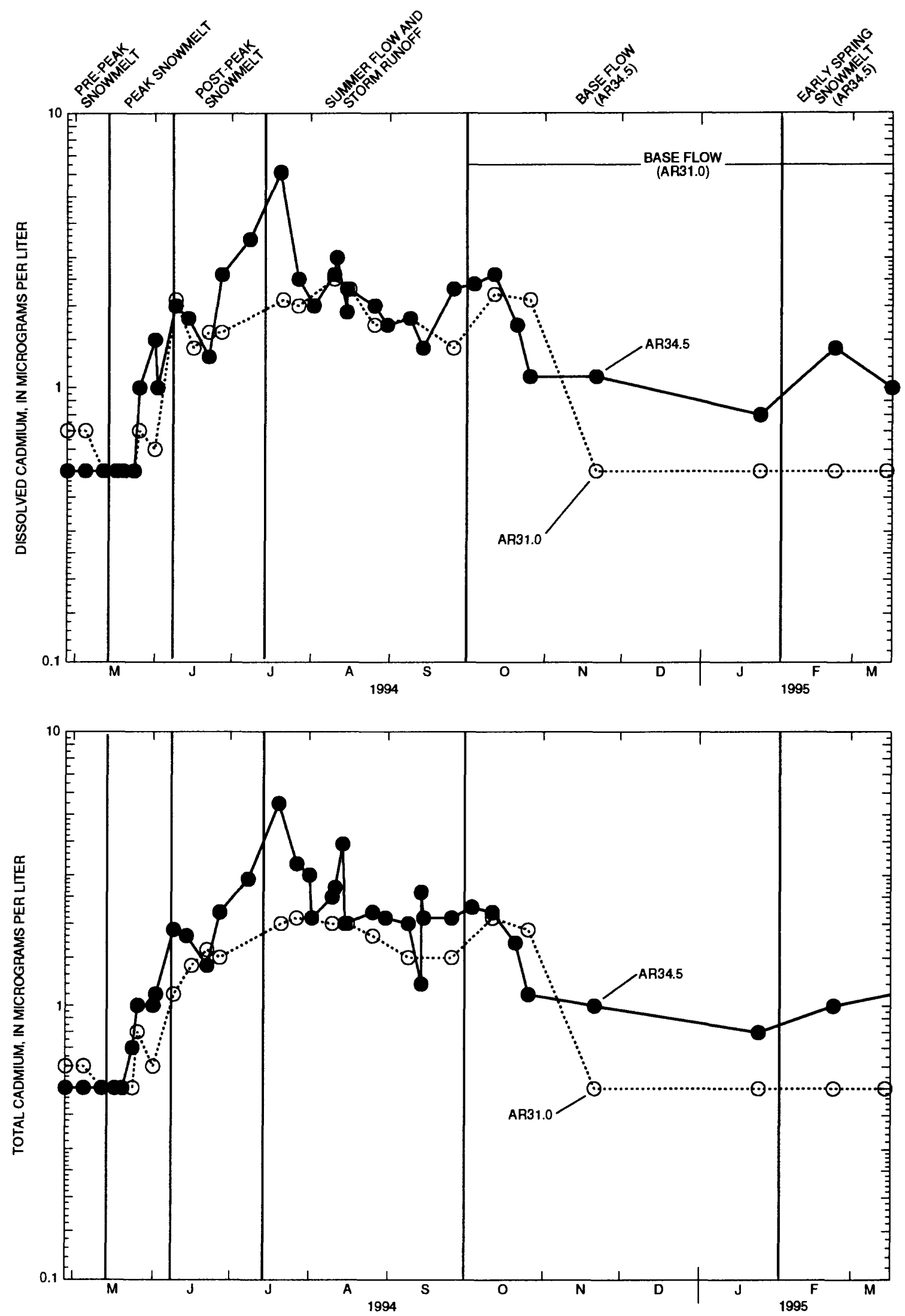

Figure 7. Dissolved- and total-cadmium concentrations for sites AR34.5 and AR31.0, April 1994 through March 1995.

Assessment of Metal Transport Into and Out of Terrace Reservoir, Conejos County, Coiorado, April 1994 Through March 1995 

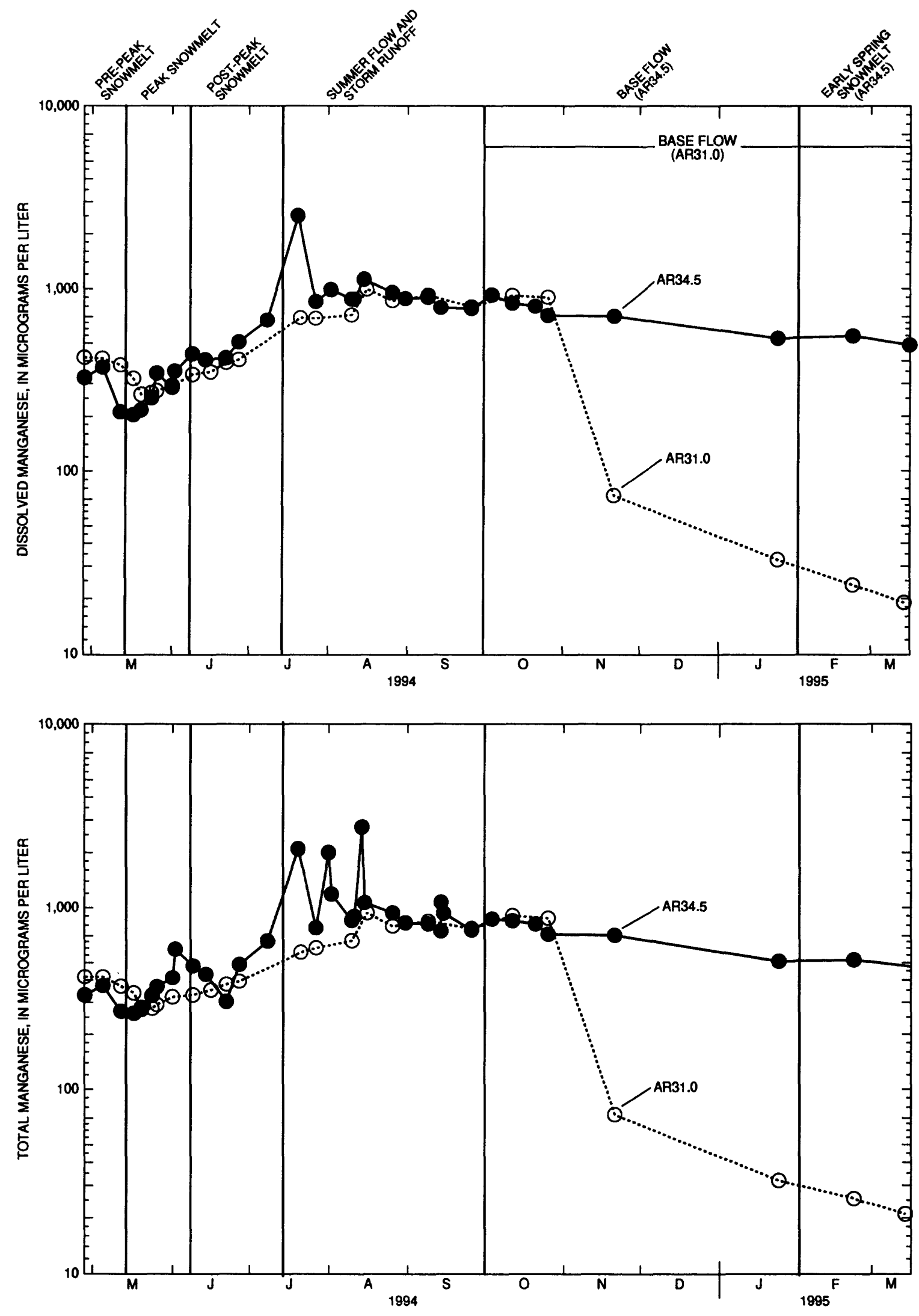

Flgure 8. Dissolved- and total-manganese concentrations for sites AR34.5 and AR31.0, April 1994 through March 1995. 

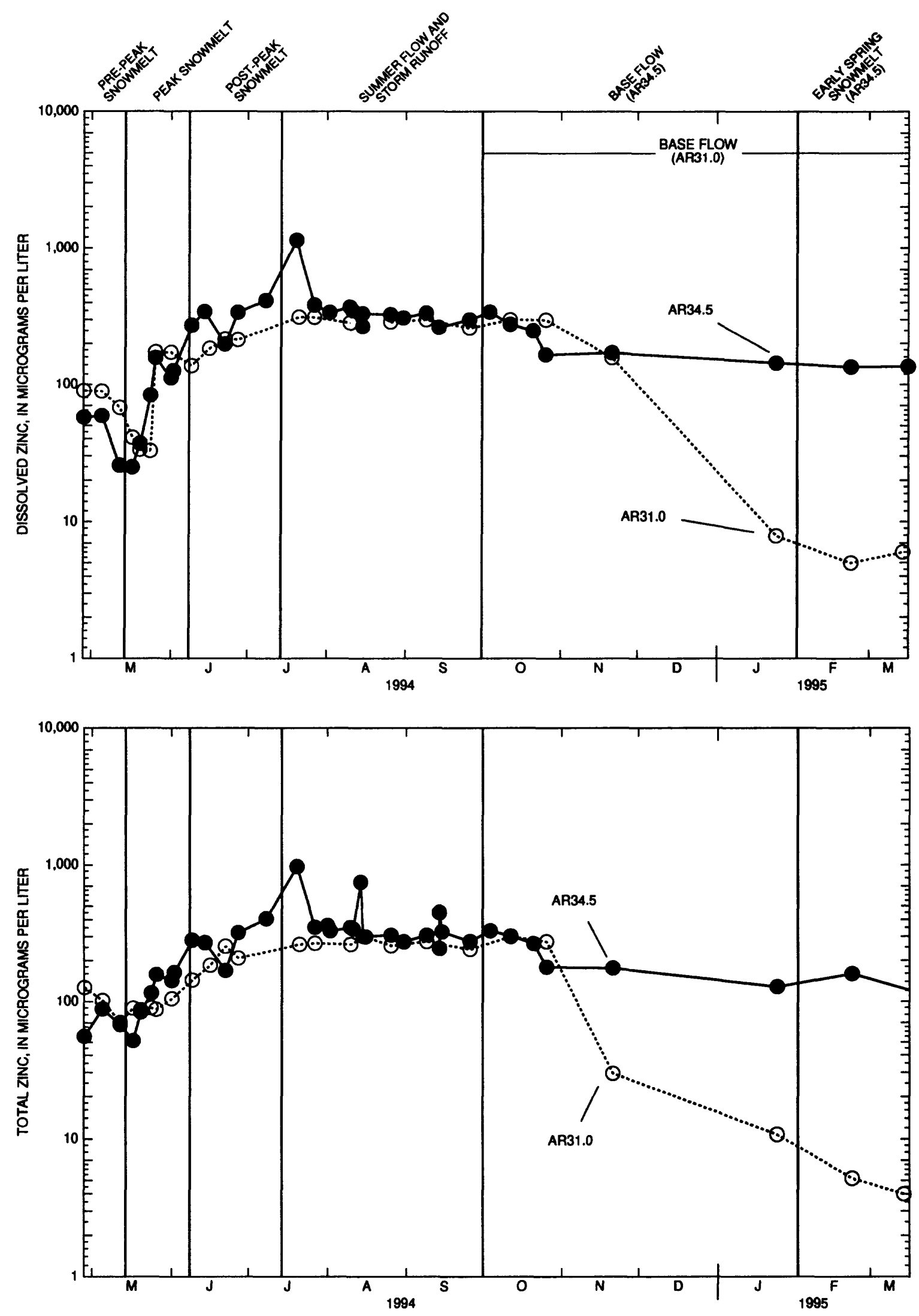

Figure 9. Dissolved- and total-zinc concentrations for sites AR34.5 and AR31.0, April 1994 through March 1995. 

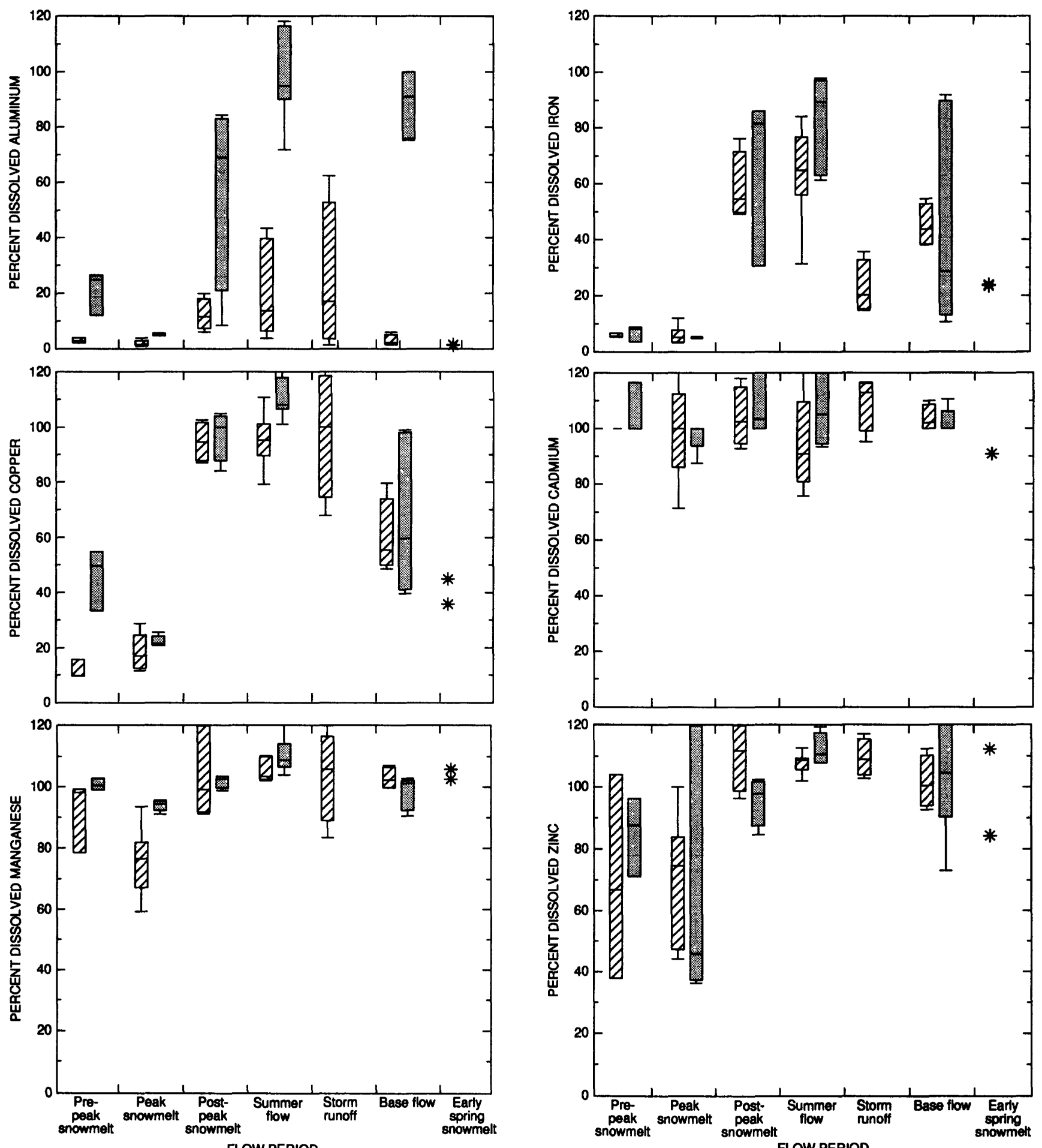

FLOW PERIOD

\section{EXPLANATION}
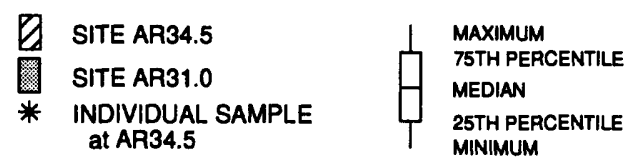

Figure 10. Temporal variations in the percentage of dissolved metals for sites AR34.5 and AR31.0, April 1994 through March 1995. 


\section{Copper}

Generally, temporal variations in the percentage of dissolved and suspended copper transported into and out of Terrace Reservoir were similar to the temporal variations for iron. During the pre-peak snowmelt and peak snowmelt periods, generally more than 80 percent of the copper was transported into the reservoir in the suspended fraction (fig. 10). However, the percentage of dissolved-copper fraction increased to more than 90 percent during the post-peak snowmelt period. As streamflow diminished during the base-flow period, the percentage of dissolvedcopper fraction decreased. The two samples collected upstream from the reservoir during the early spring snowmelt period indicated that the percentage of dissolved-copper fraction continued to decrease.

With the exception of the pre-peak snowmelt period, the temporal variations in the percentage of dissolved and suspended fraction of copper downstream from Terrace Reservoir were similar to the temporal variations that occurred upstream from the reservoir (fig. 10). During the pre-peak snowmelt period, the percentage of dissolvedcopper fraction ranged from about 35 to about 55 percent, more than two times greater than the dissolved-copper fraction upstream from the reservoir. During the peak snowmelt period, the percentage of dissolved-copper fraction decreased to about 25 percent and, conversely, the percentage of suspended fraction increased to about 75 percent. These percentages were similar to those upstream from the reservoir. During this period, when the estimated reservoir residence times were short (between 3 and 5 days), a large percentage of copper was transported into and out of Terrace Reservoir in the suspended fraction. As occurred upstream from the reservoir, a marked increase in the percentage of dissolved-copper fraction occurred during the post-peak snowmelt and the summer-flow periods. Between June 9 and September 30 (the post-peak snowmelt, the summer-flow, and the storm-runoff periods), almost all the copper was transported out of the reservoir in the dissolved fraction.

\section{Cadmium, Manganese, and Zinc}

In general, almost all the cadmium was transported into and out of the reservoir in the dissolved form (fig. 10). During the pre-peak snowmelt and peak snowmelt periods, most of the manganese and zinc generally were transported into the reservoir in the dissolved form. After about June 9, almost all the manganese and zinc entering the reservoir were in the dissolved form. Less temporal variation occurred downstream from the reservoir. In general, throughout the entire study period, almost all the manganese was transported out of the reservoir in the dissolved form; and, except for the peak snowmelt period, zinc was predominantly transported out of the reservoir in the dissolved form.

\section{Correlations of Metal Concentrations, Streamflow, Specific Conductance, and $\mathrm{pH}$}

A correlation coefficient is a statistic that is frequently used to describe the strength of a relation between two variables (Iman and Conover, 1983). Correlation coefficients are always between -1 and +1 . Positive correlation coefficients indicate that one variable increases as the other variable increases; negative correlation coefficients indicate that one variable increases as the other variable decreases. A correlation coefficient of zero indicates that each variable has no predictive ability for the other. The closer the correlation coefficient is to either $a-1$ or +1 , the stronger the relation. A correlation analysis was made on the data collected between April 1994 and March 1995 at sites AR34.5 and AR31.0. Pearson correlation coefficients were computed using $\mathrm{pH}$, the logarithms of the concentrations of the metals of concern, streamflow, and specific conductance. Because the metal concentrations, streamflow, and specific conductance were assumed not to be normally distributed, logarithms were used to transform the concentrations of metals, streamflow, and specific conductance. The results of the correlation analysis are listed in tables 3 and 4; correlations were considered significant when the correlation coefficient had a probability less than 0.05 . Significant correlations that had correlation coefficients between 0.707 and 0.865 were considered to be moderately correlated; the percentage of the explained variation was between 50 and 75 percent. Significant correlations that had correlation coefficients between 0.866 and 0.999 were considered to be strongly correlated; the percentage of the explained variation was greater than 75 percent. 


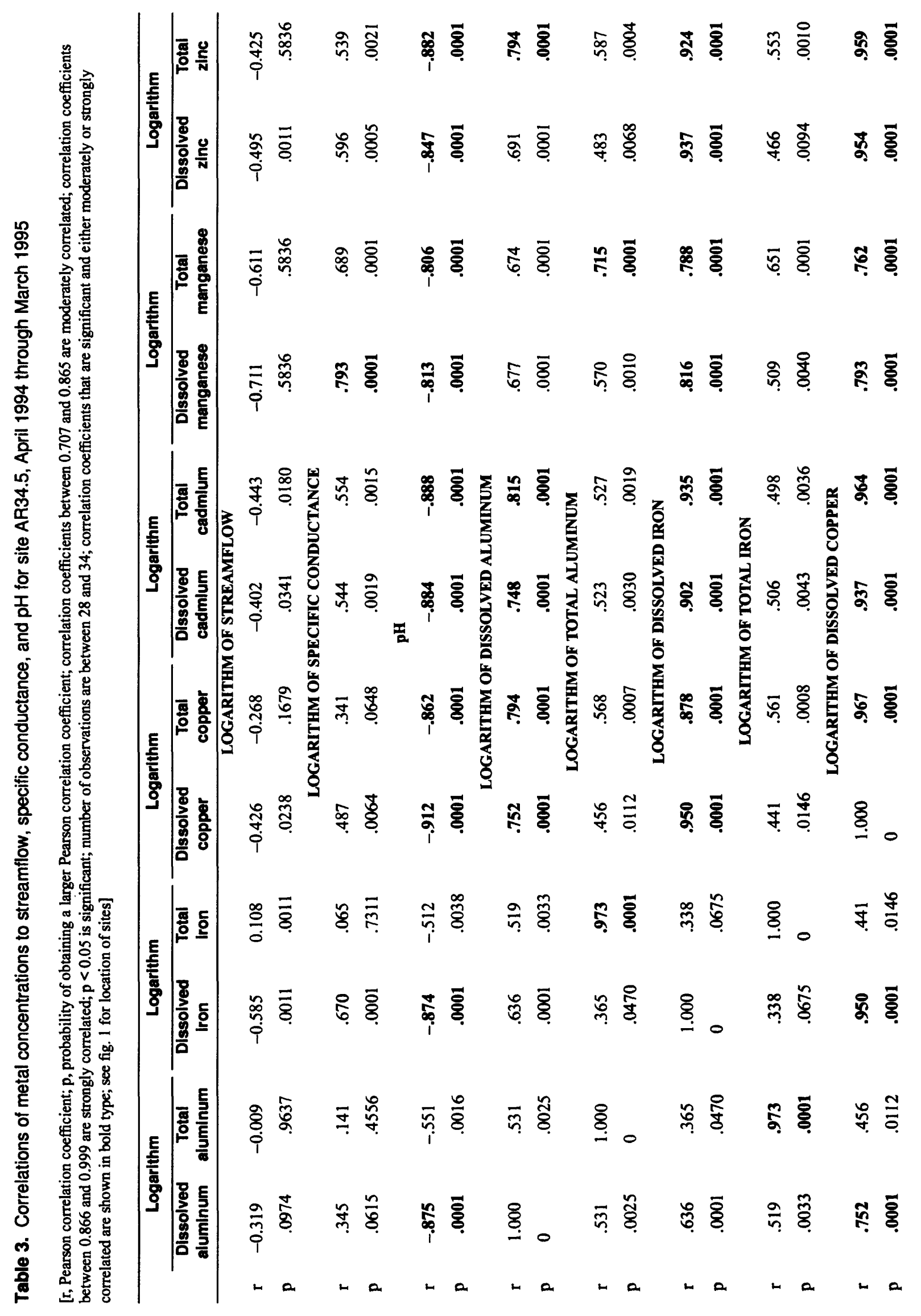




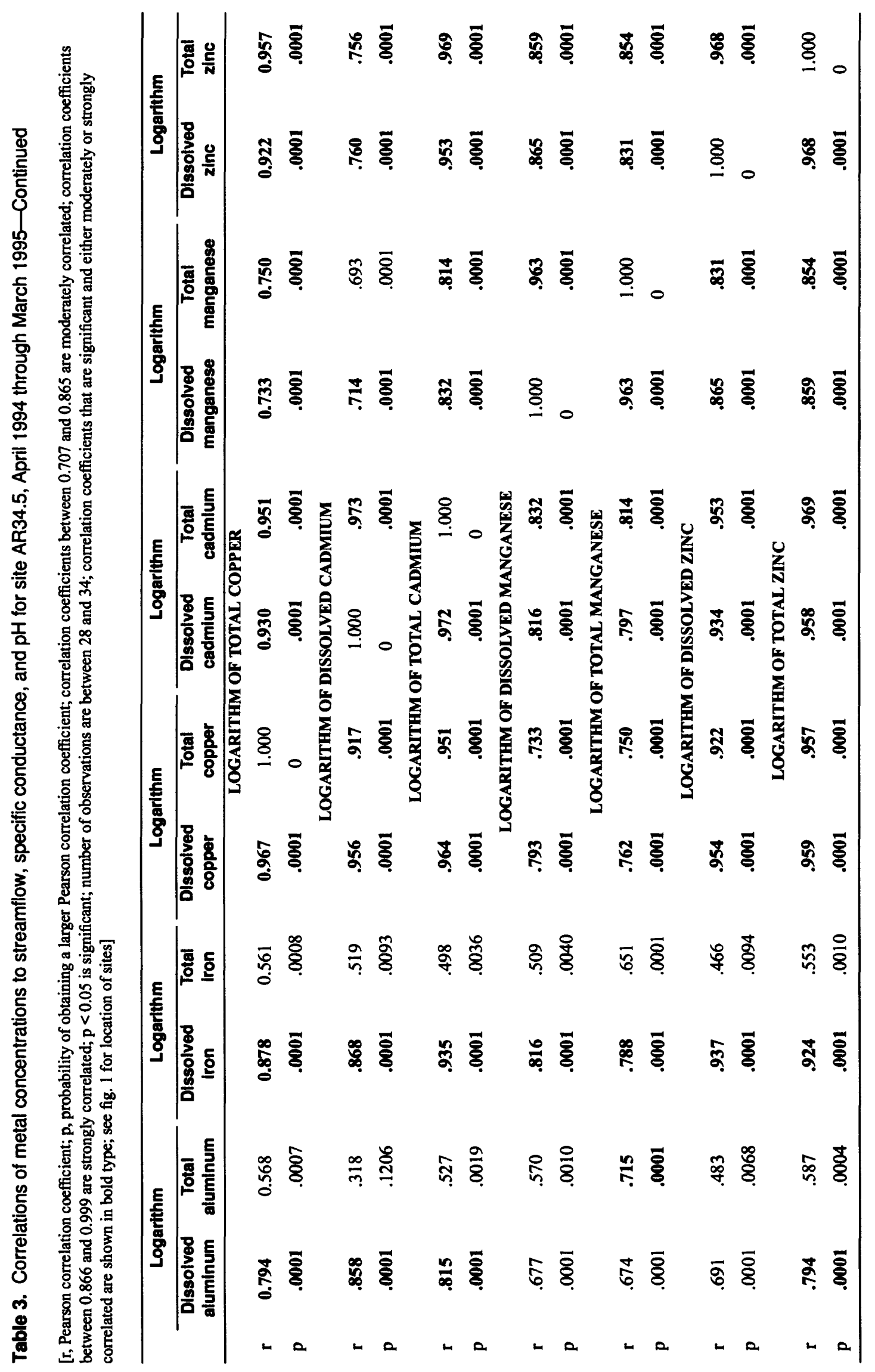




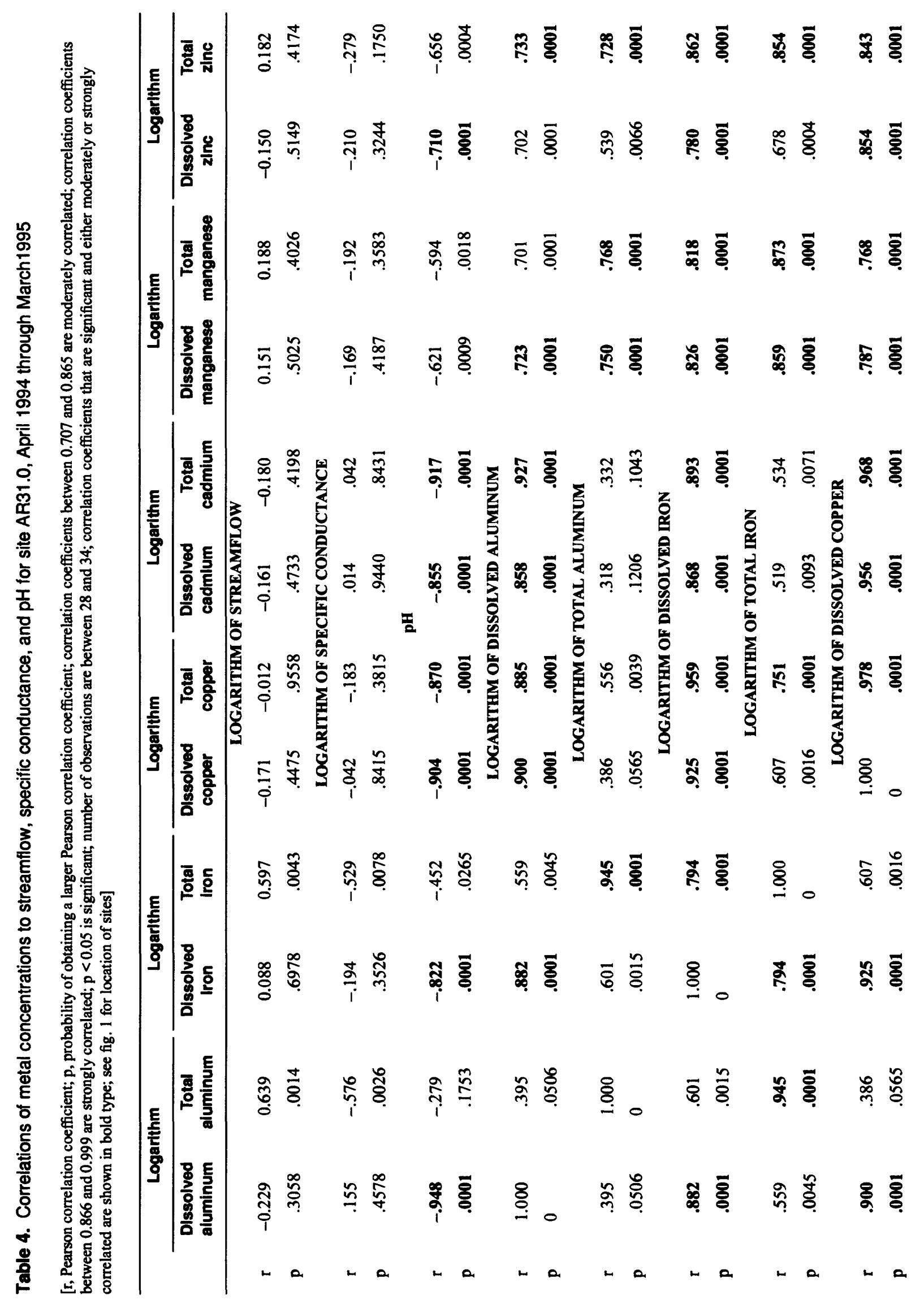




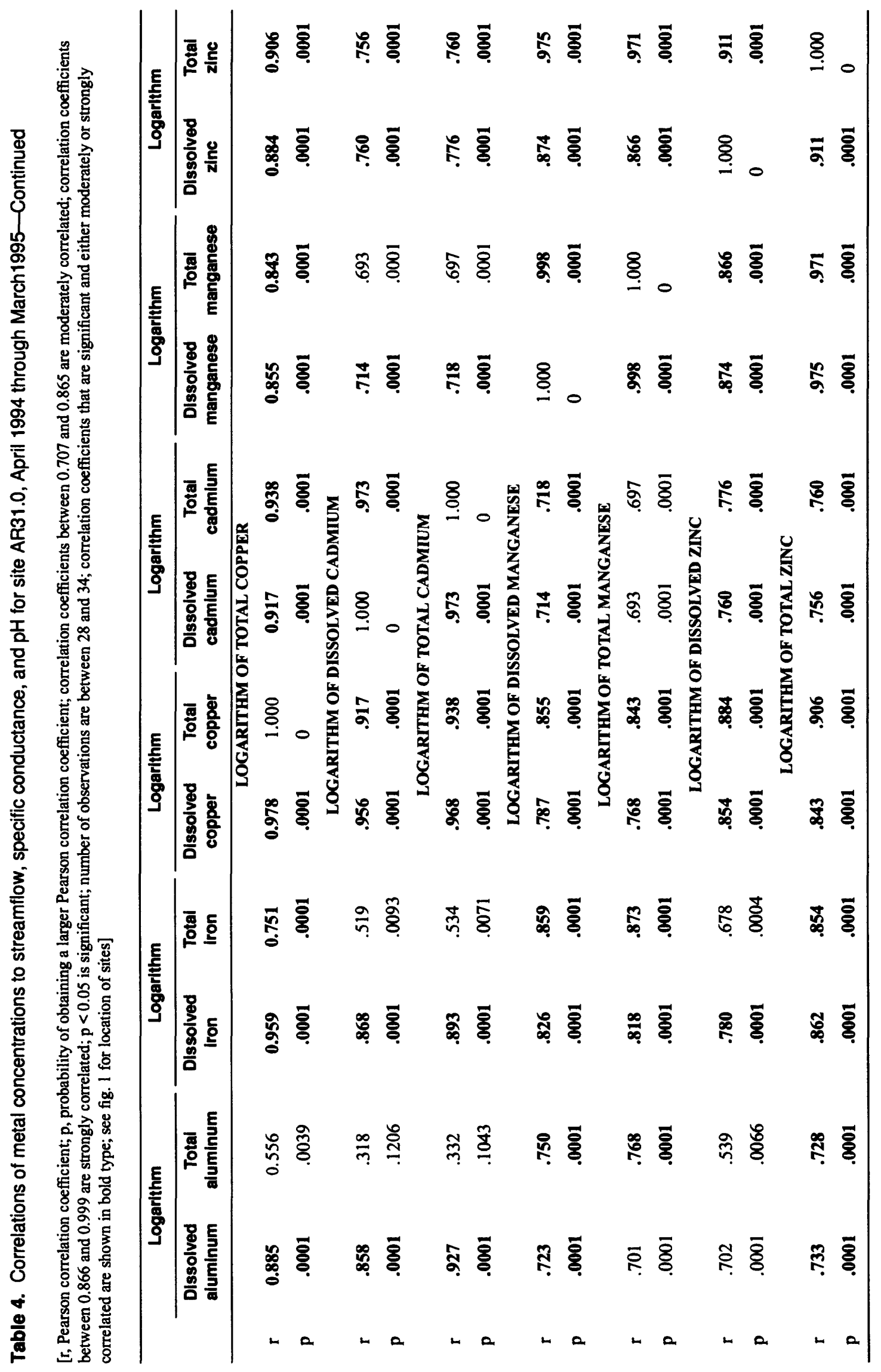


Correlation between concentrations of metals and streamflow, specific conductance, and $\mathrm{pH}$ were evaluated to determine whether field measurements of streamflow, specific conductance, or $\mathrm{pH}$ could potentially be used to predict metal concentrations. At site AR34.5, correlations of the logarithm of metal concentrations with streamflow and specific conductance generally were not significant or had correlation coefficients less than 0.6 (table 3 ), indicating that neither streamflow nor specific conductance would be a reliable predictor of metal concentrations for this site. At site AR31.0, correlations of metal concentrations with streamflow and specific conductance generally were not significant (table 4).

At both sites, the concentrations of several metals were strongly or moderately negatively correlated to $\mathrm{pH}$. At site AR34.5, $\mathrm{pH}$ was strongly correlated to concentrations of dissolved aluminum, dissolved iron, dissolved copper, dissolved and total cadmium, and total zinc. Correlation coefficients ranged from -0.874 to -0.912 (table 3 ), indicating that if a linear relation existed between $\mathrm{pH}$ and the logarithms of the concentrations of metals, $\mathrm{pH}$ could explain between 76 and 83 percent of the variation in metal concentration. Additionally, $\mathrm{pH}$ was moderately correlated to total copper, dissolved and total manganese, and dissolved zinc; correlation coefficients ranged from -0.806 to -0.862 (table 3 ), indicating that $\mathrm{pH}$ could explain between 65 and 74 percent of the variation in metal concentration. The $\mathrm{pH}$ was weakly correlated to the logarithms of concentrations of total aluminum and total iron (correlation coefficient of -0.551 and -0.512 , respectively). Because $\mathrm{pH}$ was strongly correlated with concentrations of several metals, scatterplots of $\mathrm{pH}$ and the logarithms of the concentrations of metals were made to further evaluate whether a linear relation appeared to exist between $\mathrm{pH}$ and the logarithms of the concentrations of selected metals. Upstream from Terrace Reservoir at site AR34.5, a visual observation of the plots indicated that a reasonably linear relation existed between $\mathrm{pH}$ and the logarithms of concentrations of dissolved aluminum, dissolved iron, dissolved and total copper, and dissolved and total zinc. Linear relations also existed between correlations of $\mathrm{pH}$ to the logarithms of the concentrations of metals that were moderately correlated with $\mathrm{pH}$. Downstream from Terrace Reservoir at site AR31.0, correlations of $\mathrm{pH}$ to the logarithms of concentrations of dissolved aluminum, dissolved and total copper, and total cadmium were strongly correlated (table 4). Additionally, correlations of
$\mathrm{pH}$ to the logarithms of concentrations of dissolved iron, dissolved cadmium, and dissolved zinc (table 4) were moderately correlated. However, an evaluation of scatterplots of $\mathrm{pH}$ and the logarithms of the concentrations of these metals indicated that, with the exception of dissolved aluminum, a linear relation did not exist between $\mathrm{pH}$ and the logarithms of the concentrations of these metals.

Correlations among concentrations of metals indicate that, during the study, significant correlations occurred between the concentrations of all the metals of concern. At both sites, concentrations of most of the metals were moderately to strongly correlated with one another (tables 3 and 4). Strong cross correlations between concentrations of metals indicate that the predominant source of metals was the same or that similar processes affect the metal concentrations, or both.

\section{METAL LOADS INTO AND OUT OF TERRACE RESERVOIR}

Metal loads were computed to estimate the quantity of metals that was transported into and out of Terrace Reservoir between April 1994 through March 1995. Metal loads are a function of metal concentration and streamflow and represent the amount of a metal transported past a river cross section during a specific time interval. The load estimates presented in this report are limited to dissolved and total aluminum, iron, copper, cadmium, manganese, and zinc.

There are numerous methods for computing metal loads. The simplest method of estimating loads is the time-interval method (Scheider and others, 1979), in which the data record for each site is divided into discrete intervals, generally at the midpoint between sampling points. The metal load then is estimated as the product of the concentration for that discrete period and the sum of the streamflow for that period. The primary disadvantage of this method is that the statistical uncertainty of the loads cannot be determined. Another method used for estimating loads is with regression equations between two constituents that are strongly related. Correlations between the logarithms of metal concentrations and streamflow and the logarithms of metal concentrations and specific conductance were weak (tables 3 and 4). Therefore, streamflow and specific conductance were not used to estimate concentrations for calculating metal loads. Correlations between the logarithm of 
metal concentrations and $\mathrm{pH}$ generally were strong at both sites (AR34.5 and AR31.0). However, at site AR31.0, scatterplots of the data indicated that a linear relation did not exist between $\mathrm{pH}$ and the logarithms of most of the metal concentrations; therefore, linear-regression models could not be used for predicting metal loads at site AR31.0. Correlations and scatterplots between the logarithms of metal concentrations and $\mathrm{pH}$ at site AR34.5 indicated that a linear relation existed. However, the correlations generally indicated that between 65 and 83 percent of the variation in metal concentrations could be explained with $\mathrm{pH}$; conversely, between 17 and 35 percent of the variation in metal concentrations could not be explained with $\mathrm{pH}$.

A variation of the standard time-interval method that generally allowed for an estimate of statistical certainty in load calculations and takes into account the large temporal variations that occurred in metal concentrations was used to estimate metal loads in this report. In the modified time-interval method, the data record is divided into several discrete time intervals based on changes in concentration, streamflow, or events. The mean concentration of the values that occurred during each time interval was multiplied by the mean daily streamflow to determine daily metal loads. Estimates of the daily metal loads were summed into flow-period and annual metal loads. The resulting percent standard errors using this method generally were less than 15 percent for dissolved and total aluminum, copper, cadmium, manganese, and zinc. However, at site AR31.0, standard errors for total and dissolved iron were as large as $\mathbf{3 0}$ percent and for dissolved zinc, as large as $\mathbf{5 0}$ percent.

Copper was used as the indicator constituent to determine the divisions for the time intervals for aluminum, iron, cadmium, manganese, and zinc because: (1) Copper was identified as the primary metal of concern by Morrison and Knudsen Corporation and ICF Keiser Engineers (1994); (2) copper was identified as an excellent predictor of the concentrations of iron, cadmium, manganese, and zinc at the Summitville Mine site (Miller and Van Zyl, 1995); and (3) strong cross correlations between concentrations of metals indicate that the predominant source of metals was the same or that similar processes affect the metal concentrations, or both (tables 3 and 4). The time-interval periods were made by analysis of the hydrograph and copperconcentration data, and divisions were made at large changes in copper concentration or where a change in the flow regime occurred. The divisions of time intervals for the other constituents were the same as were determined for copper. Nine time intervals were used to estimate loads at site AR31.0, and 18 time intervals were used to estimate loads at site AR34.5, with each time interval generally containing between 3 and 7 data points. Attempts were made to divide the data so that there were at least three samples in each time interval, allowing for calculation of standard errors of load estimates. However, metal loads associated with storms at site AR34.5 were calculated separately. By removing the metal concentration measured from samples collected during storms from the rest of the data for the time interval, the large metal concentrations that were associated with storms did not bias the mean concentration and standard error of the other data. Because the storms frequently contained only one or two samples, standard errors generally could not be determined for these storms.

Metal loads varied considerably as a result of changes in streamflow or changes in metal concentrations, or both. Some of the physical and chemical processes that affected metal transport through Terrace Reservoir included mixing, sorption, flocculation, and sedimentation. A summary of metal loads, by flow period, for sites AR34.5 and AR31.0 is included in table 5. Daily load estimates and standard errors for dissolved and total aluminum, iron, copper, cadmium, manganese, and zinc are presented in tables 6 and 7 in the "Supplemental Data" section at the back of this report.

\section{Aluminum}

Large variations in aluminum loads occurred during the study. The largest daily loads of total aluminum were transported into and out of Terrace Reservoir during the peak snowmelt period (fig. 11). During the peak snowmelt period, the maximum daily total-aluminum load that entered the reservoir was about 11 tons (table 7). Large daily total-aluminum loads also were transported into the reservoir during rainstorm runoff during the summer period. Most of the total-aluminum loads that entered the reservoir during rainstorm runoff remained in the reservoir (fig. 11). The smallest daily total-aluminum loads occurred during the base-flow period between November 1994 and February 1995 (fig. 11). 


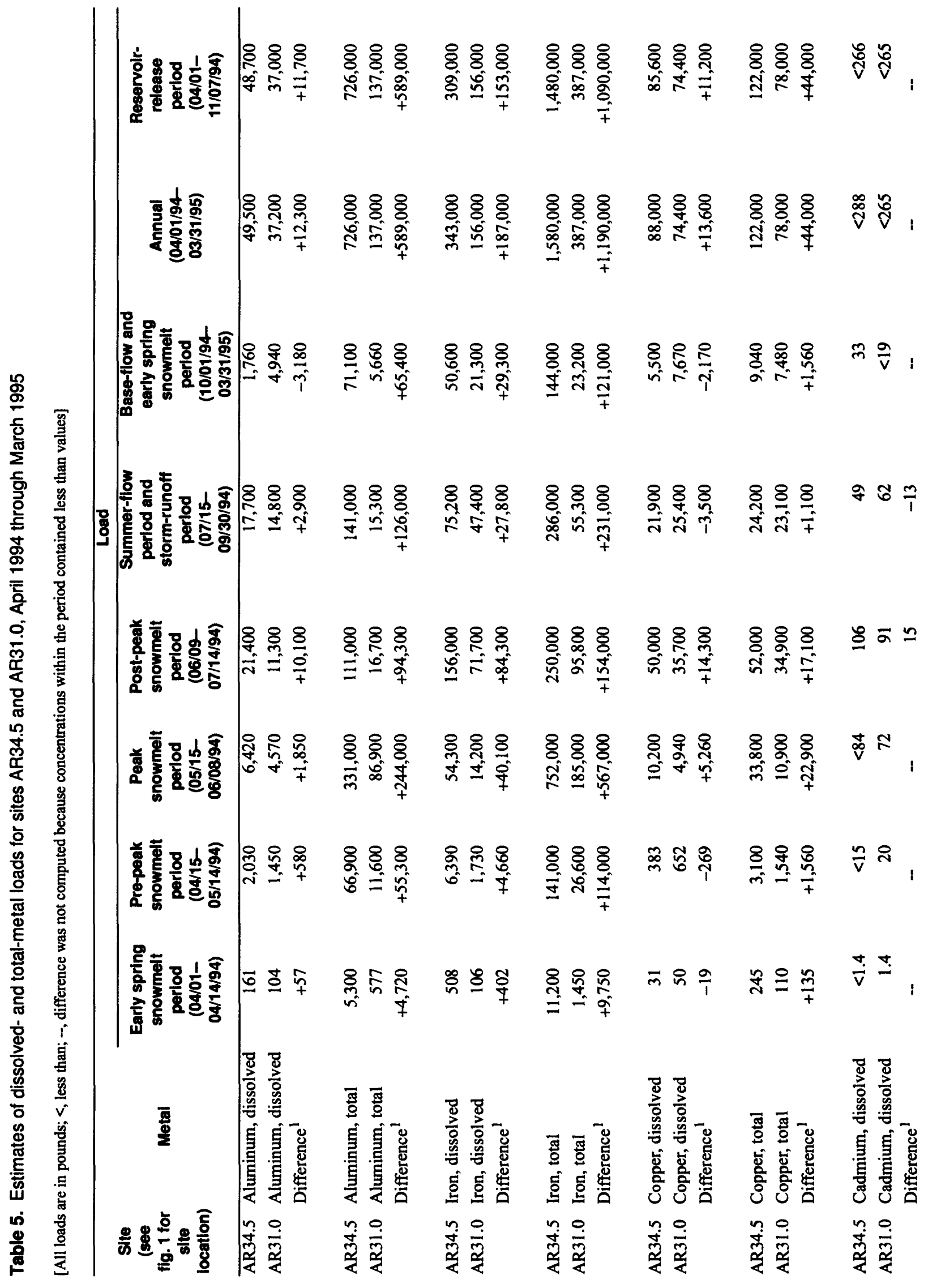




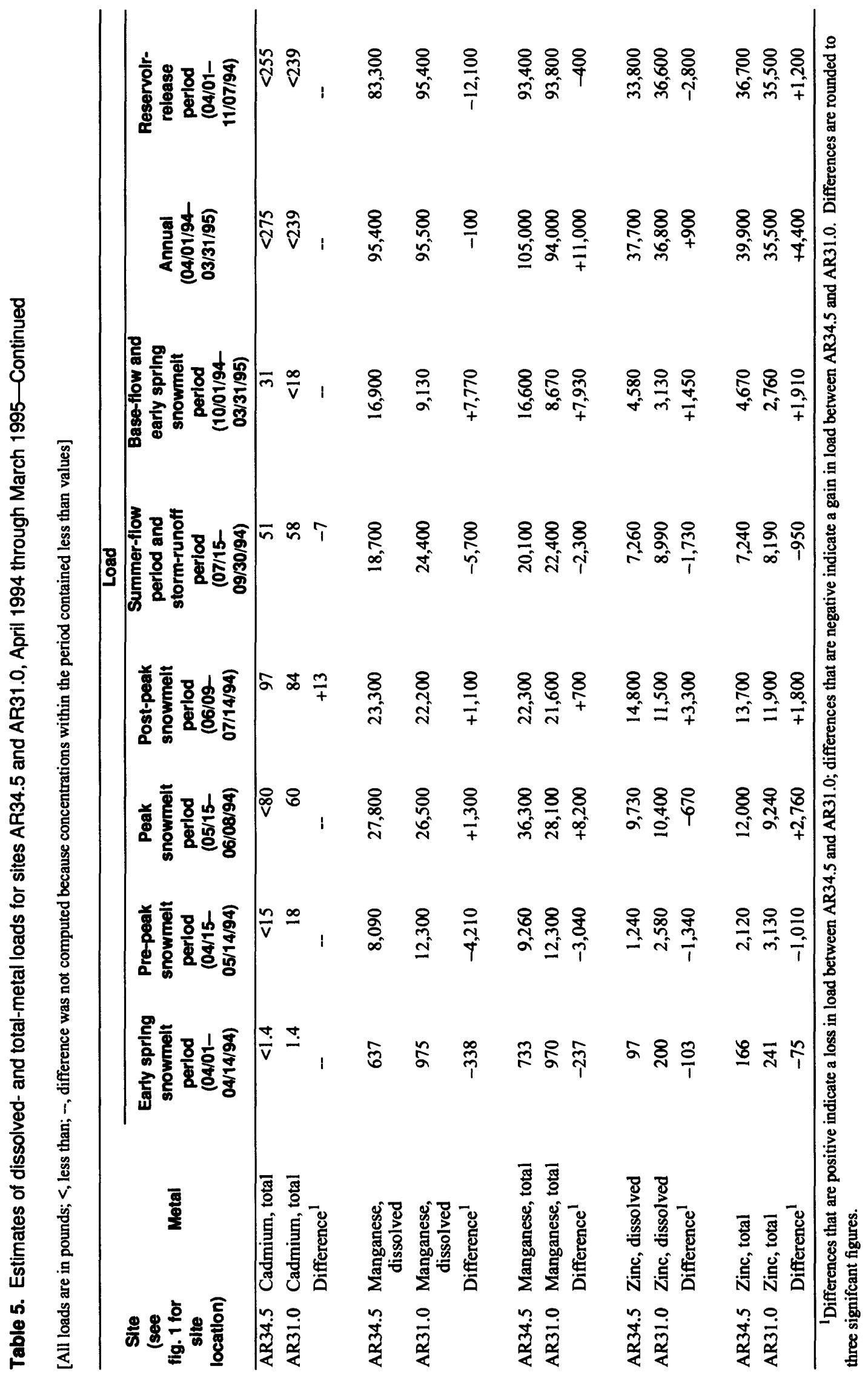


A
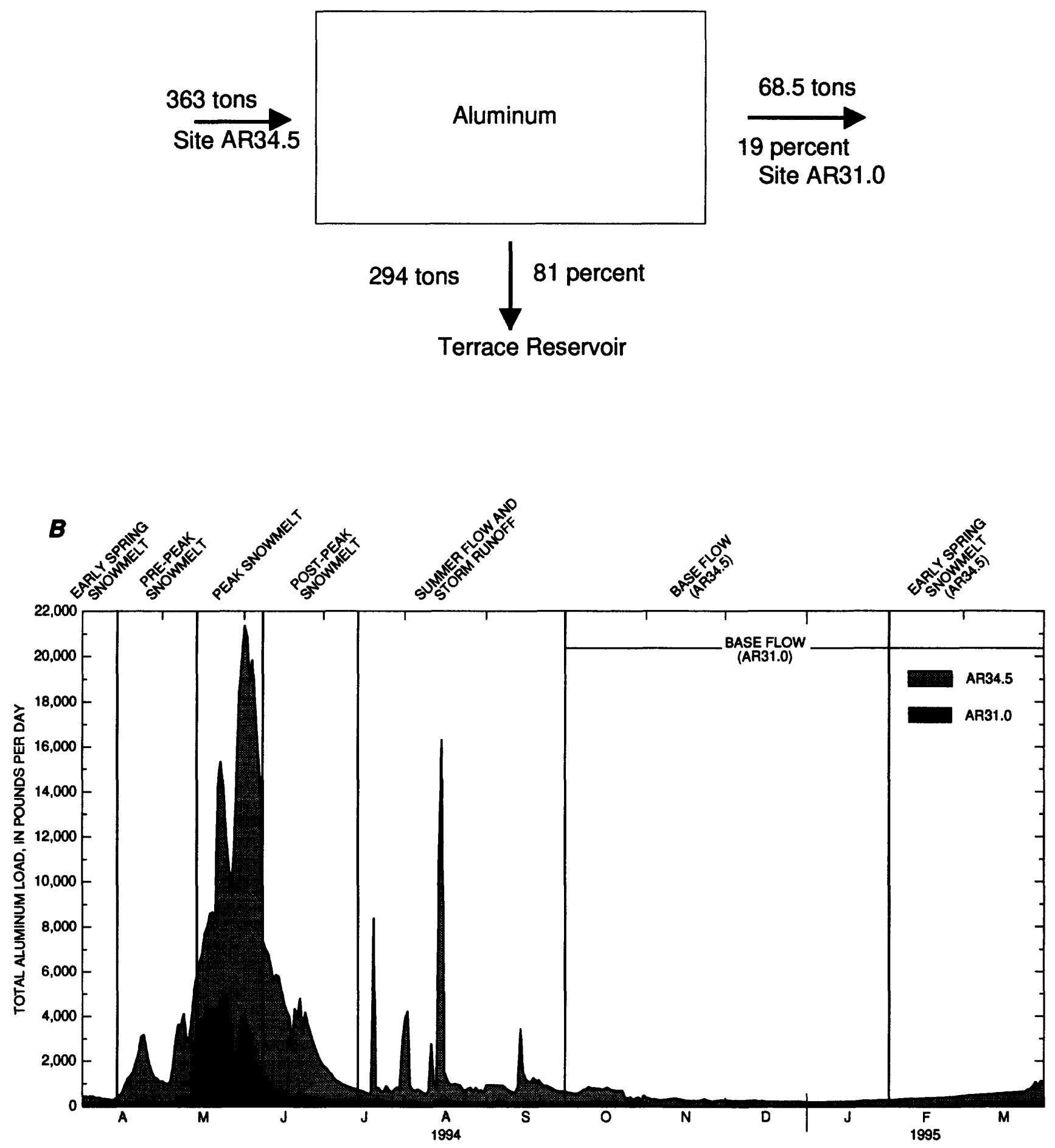

Figure 11. Annual (A) and daily (B) total-aluminum loads into (site AR34.5) and out of (site AR31.0) Terrace Reservoir, April 1994 through March 1995. 
Throughout the study, aluminum was transported into the reservoir predominantly in the suspended fraction (fig. 10). By comparison, most of the aluminum transported out of the reservoir was predominantly in the dissolved fraction, except during the pre-peak and peak snowmelt periods (fig. 10).

About 81 percent of the 363 tons of total aluminum that entered the reservoir was not transported out of the reservoir, indicating that the reservoir was a sink for an estimated 294 tons of aluminum (table 5; fig. 11). Although 81 percent of the aluminum was not transported out of the reservoir during the study, about 68.5 tons was transported downstream to the Alamosa River, and most of this load (about 63 percent) was transported out of the reservoir during the peak snowmelt period from May 15 through June 8, 1994 (table 5; fig. 11). Although most of the total-aluminum load was not transported out of the reservoir, about 75 percent of the dissolved-aluminum load that entered the reservoir was transported out of the reservoir during the study (table 5).

\section{Iron}

Large variations in iron loads occurred during the study. The largest daily total-iron loads were transported into and out of Terrace Reservoir during the peak snowmelt period (fig. 12). During the peak snowmelt period, the maximum daily totaliron load that entered the reservoir was about 25 tons (table 7). Large daily total-iron loads also were transported into the reservoir during rainstorms during the summer period, and like total-aluminum loads, almost all the total-iron loads that entered the reservoir during rainstorm runoff remained in the reservoir. The smallest daily iron loads occurred during the base-flow period between November 1994 and February 1995 (fig. 12).

During the pre-peak and peak snowmelt periods, more than 90 percent of the iron was transported into and out of the reservoir in the suspended fraction (fig. 10). However, most of the iron transported into and out of the reservoir during the post-peak snowmelt and summer-flow periods was transported in the dissolved fraction. During these periods, about 60 percent of the iron entering the reservoir generally was in the dissolved fraction; and generally more than 70 percent of the iron being discharged from the reservoir was in the dissolved fraction (fig. 10).
An estimated 75 percent of the 790 tons of total iron that entered the reservoir remained in the reservoir, indicating that the reservoir was a sink for an estimated 596 tons of iron (table 5; fig. 12). Although 75 percent of the iron was not transported through the reservoir, about 194 tons was transported downstream to the Alamosa River, and most of this load (about 73 percent) was transported out of the reservoir during the peak and post-peak snowmelt periods from May 15 through July 14, 1994 (table 5; fig. 12).

Between April 1 and June 8, 1994, most of the dissolved iron that entered the reservoir probably was in colloidal form (that is, less than $0.45 \mu \mathrm{m}$ ), which aggregated, then settled from the reservoir water column under the low gradient conditions of the reservoir, resulting in almost a 75-percent loss in dissolved iron at site AR31.0 (downstream from Terrace Reservoir). Between June 9 and September 30, 1994, about 50 percent of the dissolved iron that entered the reservoir was transported out of the reservoir (table 5).

\section{Copper}

The maximum daily total-copper load of about 3,770 lbs (about 1.9 tons) entered the reservoir on June 8, about a week later than the maximum daily total-aluminum and total-iron loads (table 7). This was a substantially smaller load than the daily maximum total-aluminum and iron loads that entered the reservoir. Although the maximum daily load occurred at the end of the peak snowmelt period, the largest copper loads were transported into and out of the reservoir during the post-peak snowmelt period (fig. 13). Almost 45 percent of the annual total-copper load was transported into and out of Terrace Reservoir during the post-peak snowmelt period (table 5), which corresponded to a period when streamflow had substantially diminished. The smallest daily total-copper loads occurred during the base-flow period between November 1994 and February 1995 (fig. 13).

During the pre-peak and peak snowmelt periods, most of the copper transported into and out of the reservoir was in the suspended fraction. During these periods, about two-thirds of the approximately 18.5 tons of total copper that entered the reservoir (table 5) remained in the reservoir and was not discharged downstream to the Alamosa River. 
A

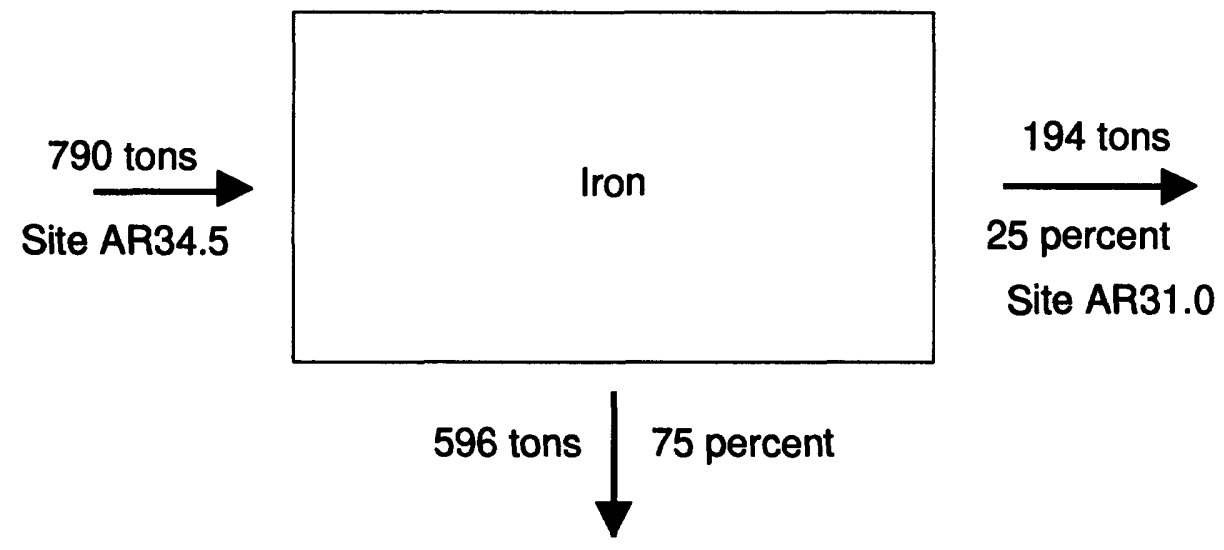

Terrace Reservoir

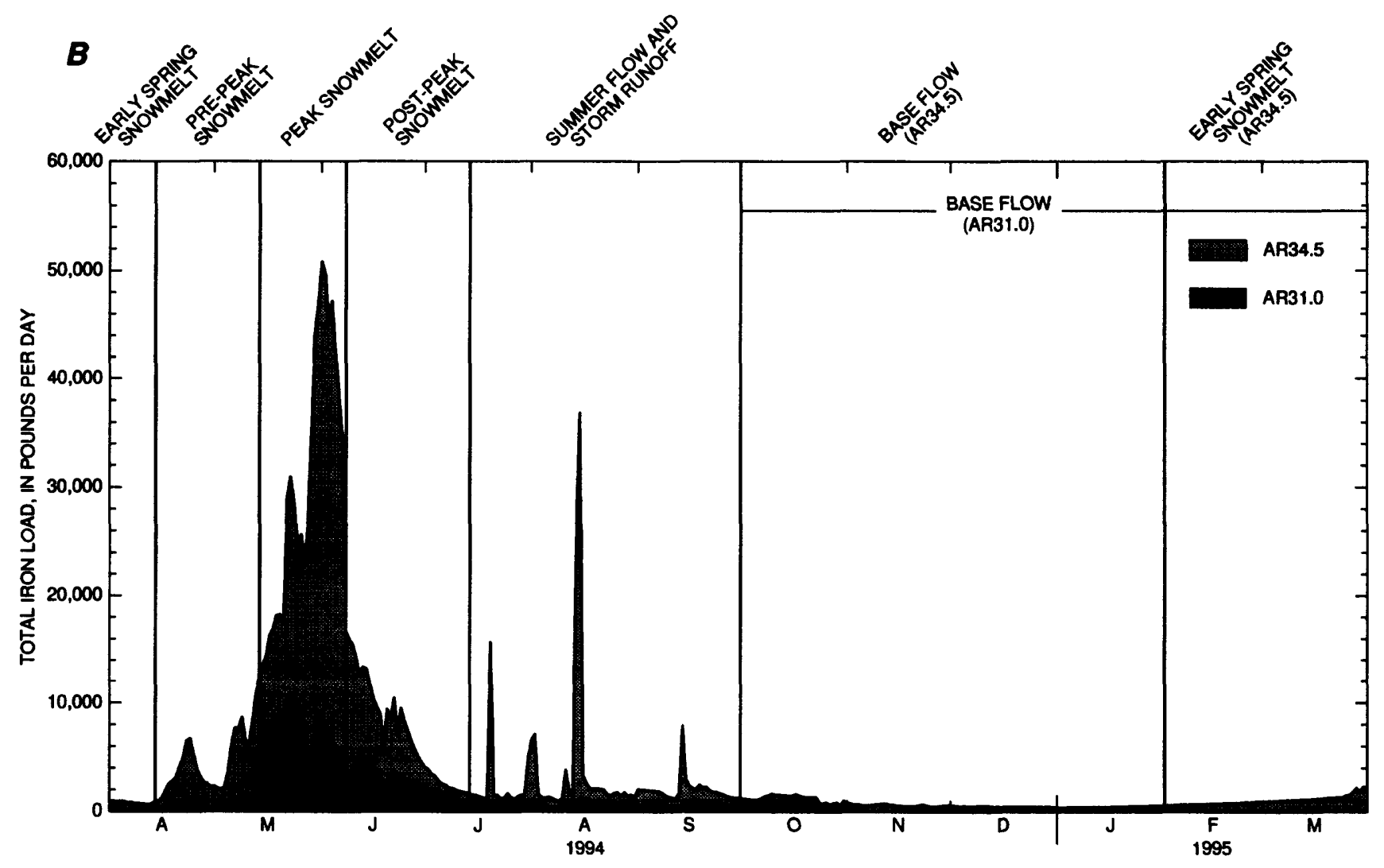

Flgure 12. Annual (A) and daily (B) total-iron loads into (site AR34.5) and out of (site AR31.0) Terrace Reservoir, April 1994 through March 1995. 

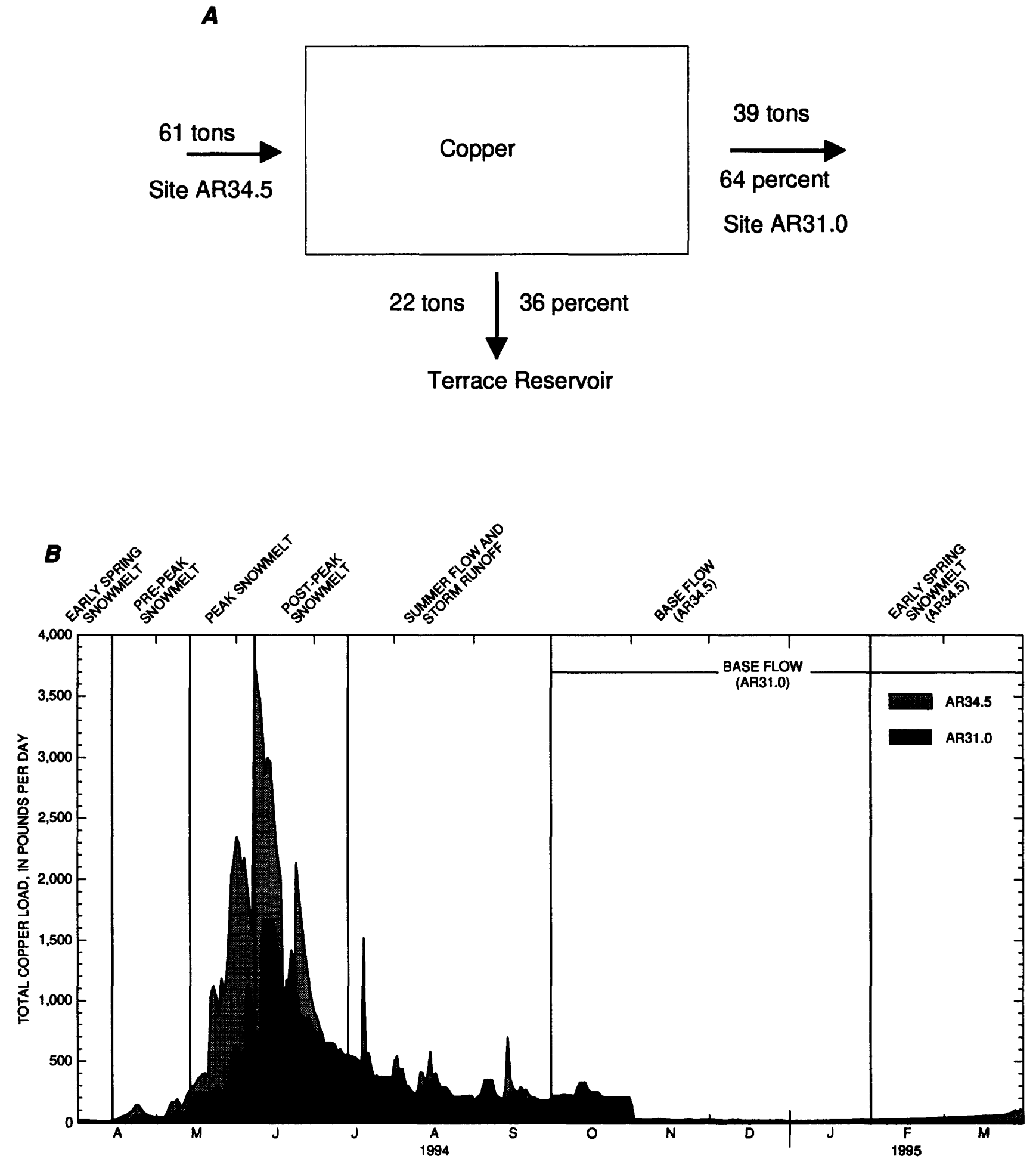

Flgure 13. Annual (A) and daily (B) total-copper loads into (site AR34.5) and out of (site AR31.0) Terrace Reservoir, April 1994 through March 1995. 
However, as indicated previously, most of the copper generally was transported into and out of the reservoir in the dissolved fraction during the post-peak snowmelt, summer-flow, storm-runoff, and base-flow periods; and generally more than 90 percent of the copper that was transported into and out of the reservoir during post-peak snowmelt and summer-flow periods was in the dissolved fraction (fig. 10). During the post-peak snowmelt and summer-flow periods, about 75 percent of the approximately 38 tons of total copper that entered the reservoir was transported out of the reservoir (table 5; fig. 13).

Overall, during the study, an estimated 39 tons of total copper was discharged from the reservoir downstream to the Alamosa River, and an estimated 22 tons of total copper remained in the reservoir. Between April 1 and November 7, 1994, the period when water was released from the reservoir, the dissolved-copper load transported out of the reservoir was about 87 percent of the dissolved-copper load transported into the reservoir, and the total-copper load transported out of the reservoir was about 64 percent of the total-copper load transported into the reservoir (table 5).

\section{Cadmium}

Throughout the study, cadmium was transported into and out of the reservoir almost entirely in the dissolved fraction (fig. 10). Daily total-cadmium loads ranged from less than 0.1 to about $6.5 \mathrm{lbs}$ (table 7). The maximum daily total-cadmium load occurred on the same date, June 8 , as the maximum daily total-copper load. In general, most of the cadmium load was transported through the reservoir (table 5). The data indicate that between about 75 and 85 percent of the total-cadmium load that entered the reservoir during the peak and post-peak snowmelt periods was transported out of the reservoir. Overall, less than $275 \mathrm{lbs}$ of total-cadmium load entered the reservoir, and less than $239 \mathrm{lbs}$ of total cadmium was transported out of the reservoir (table 5). Between April 1 and November 7, 1994, the period when the reservoir was releasing water, the cadmium load transported out of the reservoir was nearly equivalent to the cadmium load transported into the reservoir (table 5).

\section{Manganese}

Large variations in manganese loads occurred during the study (fig. 14). The largest daily manganese loads were transported into and out of Terrace Reservoir during the peak snowmelt period (fig. 14). During the peak snowmelt period, the maximum daily total-manganese load that entered the reservoir was about $2,230 \mathrm{lbs}$ (table 7 ), or slightly more than 1 ton. The maximum daily total-manganese load occurred on June 1, 1994, the same date as the maximum aluminum and iron loads and about a week earlier than the maximum daily copper and cadmium loads (table 7). Large daily total-manganese loads also were transported into the reservoir during rainstorms during the summer period. Most of the total-manganese loads that entered the reservoir during rainstorm runoff did not appear to have been transported out of the reservoir (fig. 14). The smallest daily manganese loads occurred during the base-flow period between November 1994 and February 1995 (fig. 14).

Throughout the study, most of the manganese was transported into and out of the reservoir in the dissolved fraction (fig. 10). However, during the peak snowmelt period, between 20 and 30 percent of the manganese was transported into the reservoir in the suspended fraction (fig. 10).

About 90 percent of the 52.5 tons of totalmanganese load that entered the reservoir was transported out of the reservoir, indicating that the reservoir was a sink for only a small fraction of manganese (table 5; fig. 14). About 55 percent of the annual total-manganese load was transported into and out of the reservoir during the peak and post-peak snowmelt periods (table 5).

\section{Zinc}

The maximum daily total-zinc load of about 943 lbs entered the reservoir on June 8, 1994, the same date as the maximum daily total-copper and total-cadmium loads and about a week later than the maximum daily total-aluminum, iron, and manganese loads (table 7). Although the maximum daily load occurred at the end of the peak snowmelt period, the largest zinc loads were transported into and out of the reservoir during the post-peak snowmelt period (table 5; fig. 15) - a period when streamflow had substantially diminished. 

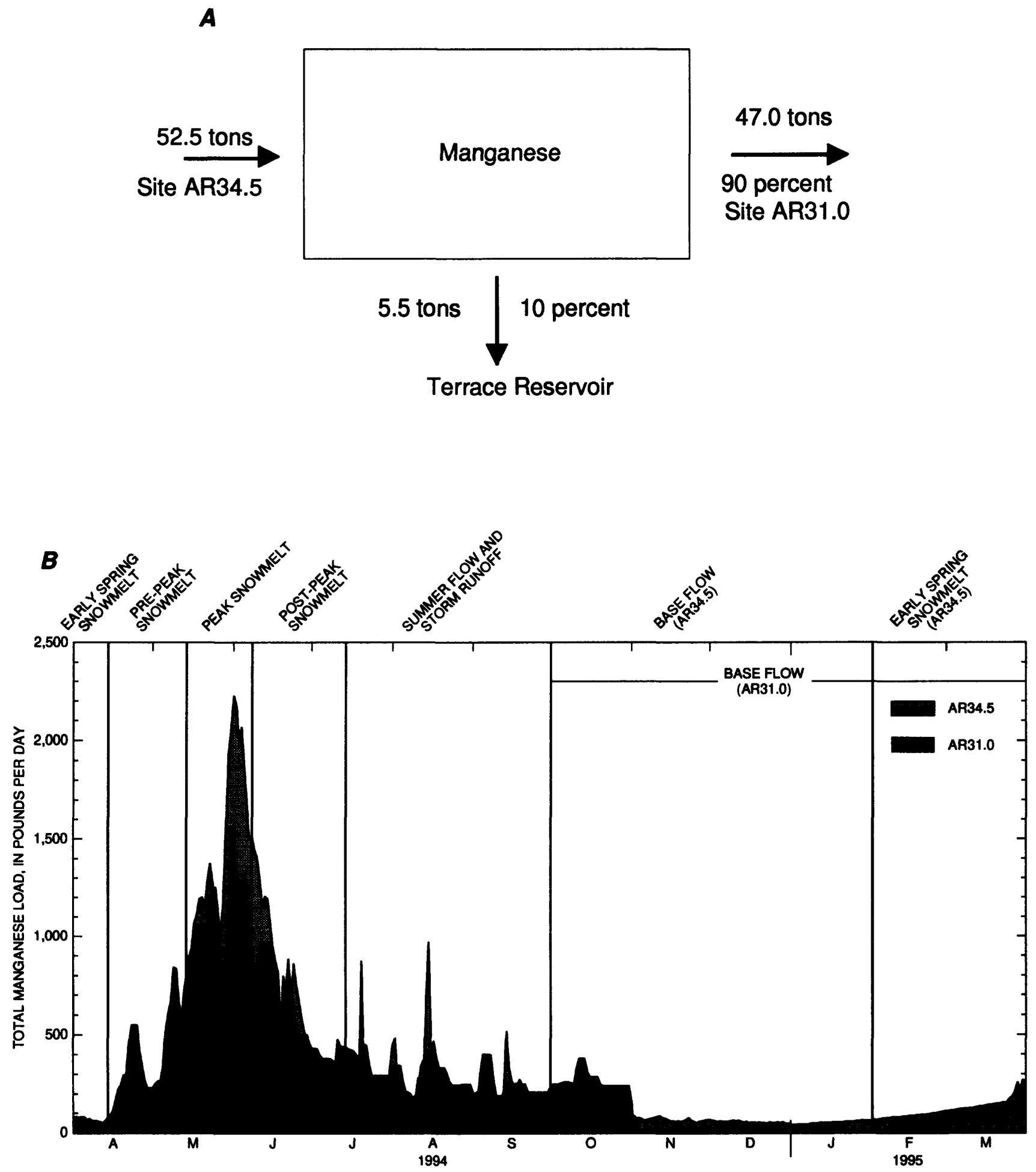

Flgure 14. Annual (A) and daily (B) total-manganese loads into (site AR34.5) and out of (site AR31.0) Terrace Reservoir, April 1994 through March 1995. 
A
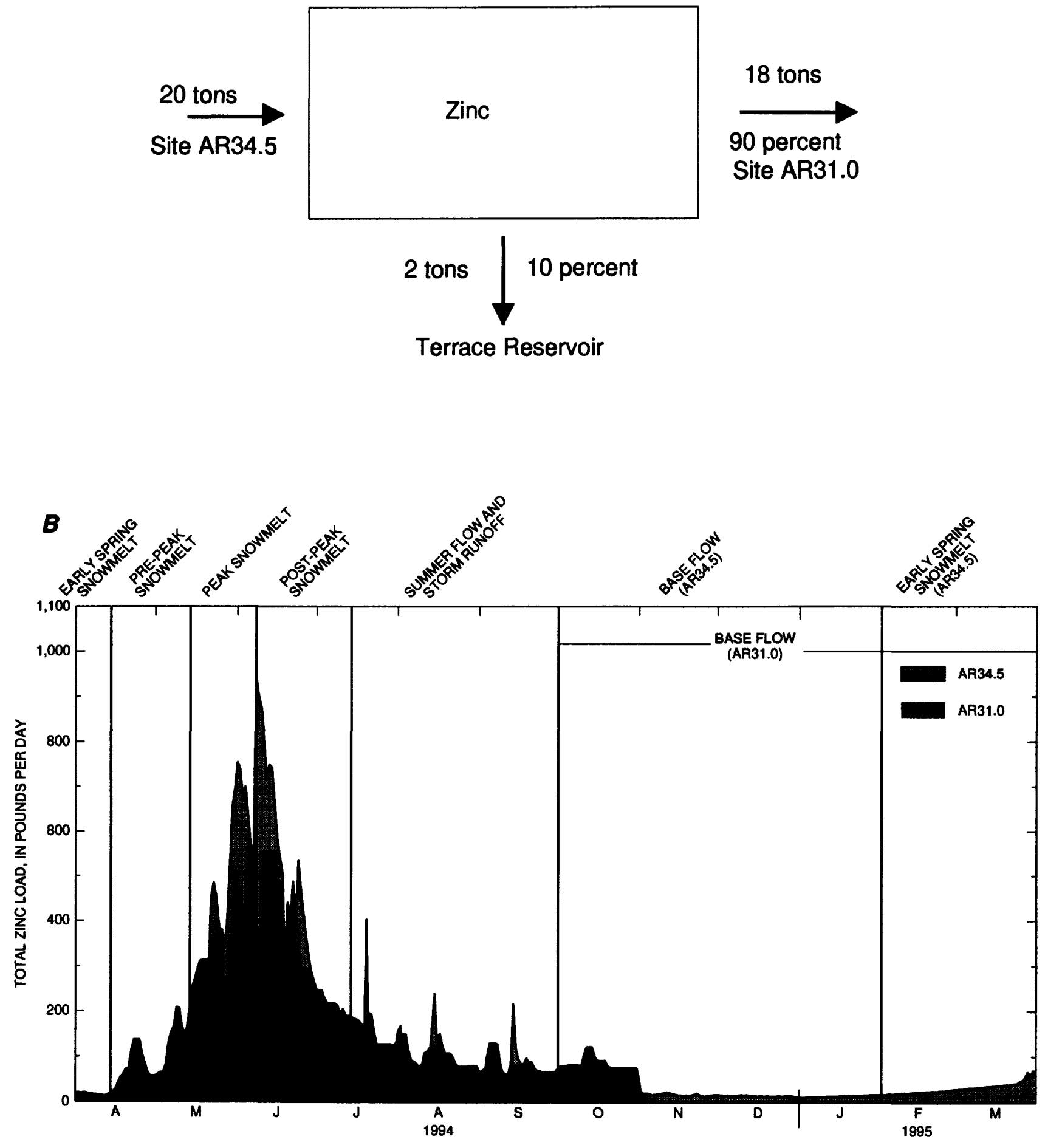

Flgure 15. Annual (A) and daily (B) total-zinc loads into (site AR34.5) and out of (site AR31.0) Terrace Reservoir, April 1994 through March 1995. 
Upstream from Terrace Reservoir, total-zinc loads increased substantially during rainstorms during the summer period. Most of the total-zinc loads that entered the reservoir during rainstorm runoff did not appear to have been transported out of the reservoir (fig. 15). The smallest daily zinc loads occurred during the base-flow period between November 1994 and February 1995 (fig. 15).

During most of the study, zinc was transported into and out of the reservoir mostly in the dissolved fraction (fig. 10). However, during the pre-peak and peak snowmelt periods, about 30 percent of the zinc generally was transported into the reservoir in the suspended fraction (fig. 10).

During the study, about 90 percent of the 20 tons of total zinc that entered the reservoir was transported out of the reservoir, indicating that the reservoir was a sink for only a small fraction of zinc (table 5; fig. 15). About 60 percent of the annual total-zinc load was transported out of the reservoir between May 15 and July 14, 1994, during the peak and post-peak snowmelt periods. Another 23 percent of the annual total-zinc load was transported out of the reservoir during the summer-flow period from July 15 through the end of September 1994.

\section{SUMMARY}

Terrace Reservoir is a small irrigation reservoir located on the Alamosa River at an elevation of about $8,550 \mathrm{ft}$ above sea level in the San Juan Mountains in Conejos County, Colorado. The Alamosa River and Terrace Reservoir are the primary sources of water for crops and livestock in the southwestern part of the San Luis Valley. Much of the drainage basin upstream from Terrace Reservoir contains extensive areas of mineralized rocks that in some places have been mined and that contribute a substantial metal load to Terrace Reservoir. Gold, silver, copper, and lead mining have occurred in the basin for more than 100 years, and extensive mining activities have occurred intermittently at the Summitville Mine. Historically, the Summitville Mine site has produced highly acidic, metal-enriched water that drained from the mine site into Wightman Fork and flowed to the Alamosa River and Terrace Reservoir.

A comparison of the streamflow hydrographs upstream and downstream from Terrace Reservoir indicated that from April 1 through June 8, 1994, the volume of water released from Terrace Reservoir was within 5 percent of the volume of water that entered the reservoir. During the post-peak snowmelt and summer-flow periods, more water was released from the reservoir than entered the reservoir due to downstream irrigation demand. During the base-flow and early spring snowmelt periods from October 1, 1994, through March 31, 1995, 46 percent more water entered the reservoir than was released from the reservoir. Over the entire study period, there was only a small difference between the volume of water that entered the reservoir and the volume of water that was released from the reservoir.

During the study period, $\mathrm{pH}$ immediately upstream from Terrace Reservoir ranged from 4.3 to 7.8. The highest $\mathrm{pH}$ occurred during the pre-peak snowmelt period; the lowest $\mathrm{pH}$ occurred during storm runoff during summer. Downstream from Terrace Reservoir, $\mathrm{pH}$ ranged from 4.6 to 7.6 . The highest $\mathrm{pH}$ occurred during the pre-peak snowmelt period, and the lowest $\mathrm{pH}$ occurred during summer in mid-July.

Large spatial and temporal variations in concentrations of the metals of concern occurred during the study. The median and maximum concentrations of dissolved and total aluminum, iron, copper, cadmium, manganese, and zinc were larger upstream from the reservoir than downstream from the reservoir. Upstream and downstream from Terrace Reservoir, the largest concentrations of dissolved aluminum, iron, copper, cadmium, manganese, and zinc generally occurred between mid-June and November. Upstream from the reservoir, the largest concentrations of total aluminum, iron, copper, cadmium, manganese, and zinc generally occurred between July and September during storm runoff. After November, dissolvedand total-metal concentrations generally decreased downstream from the reservoir after the closure of the reservoir outlet works.

Throughout the study, aluminum was transported into the reservoir predominantly in the particulate or suspended form. Downstream from the reservoir, the suspended-aluminum fraction was predominant only during the pre-peak snowmelt and peak snowmelt periods. After June 8, most of the aluminum that was transported out of Terrace Reservoir was in the dissolved fraction. During the pre-peak snowmelt and peak snowmelt periods, more than 90 percent of the iron was transported into the reservoir in the suspended fraction. However, the dissolved fraction of iron generally increased to more than 50 percent during the post-peak snowmelt and 
summer-flow periods. The temporal variations in the percentage of dissolved and suspended fraction of iron downstream from Terrace Reservoir were similar to the temporal variations that occurred upstream from the reservoir. Generally, the temporal variations in the percentage of dissolved and suspended copper transported into and out of Terrace Reservoir were similar to the temporal variations that occurred with the percentage of dissolved and suspended iron that was transported into and out of Terrace Reservoir. With the exception of the pre-peak snowmelt period, the temporal variations in the percentage of dissolved and suspended fraction of copper downstream from Terrace Reservoir were similar to the temporal variations that occurred upstream from the reservoir. During the entire study period, cadmium, manganese, and zinc generally were transported into and out of the reservoir predominantly in the dissolved form.

Logarithms of metal concentrations generally were not significantly correlated with streamflow or the logarithm of specific conductance. Correlations between the logarithms of metal concentrations and $\mathrm{pH}$ generally were strong upstream and downstream from the reservoir. However, downstream from the reservoir, scatterplots of the data indicated that a linear relation did not exist between $\mathrm{pH}$ and the logarithms of the metal concentrations. Correlations and scatterplots between the logarithms of metal concentrations and $\mathrm{pH}$ upstream from the reservoir indicated that a linear relation existed. The correlations generally indicated that between 65 and 83 percent of the variation in metal concentrations could be explained by $\mathrm{pH}$. The metals of concern were significantly correlated with one another. Because the correlations among the logarithms of the concentrations of metals generally were good, copper was used as the indicator constituent to determine the divisions for the time intervals for estimating aluminum, iron, cadmium, manganese, and zinc loads.

Metal loads varied considerably as a result of changes in streamflow or changes in metal concentrations, or both. The largest daily loads of aluminum, iron, and manganese were transported into and out of Terrace Reservoir during the peak snowmelt period. The smallest metal loads occurred during the base-flow period between November 1994 and February 1995. About 81 percent of the 363 tons of total aluminum that entered the reservoir remained in the reservoir, indicating that the reservoir was a sink for an estimated 294 tons of aluminum. About 75 percent of the 790 tons of total iron that entered the reservoir remained in the reservoir, indicating that the reservoir was a sink for an estimated 596 tons of iron. The maximum daily total-copper load entered the reservoir on June 8, about a week later than the maximum daily total-aluminum and total-iron loads. The largest copper loads were transported into and out of the reservoir during the post-peak snowmelt period. Overall, during the study, an estimated 39 tons of total copper was discharged from the reservoir downstream to the Alamosa River, and about 22 tons of total copper remained in the reservoir. Between April 1 and November 7, 1994, the period when the reservoir was releasing water, the totalcopper load transported out of the reservoir was about 64 percent of the total-copper load transported into the reservoir. About 90 percent of the total-manganese and total-zinc loads that entered the reservoir was transported out of the reservoir, indicating that the reservoir was a sink for only a small fraction of manganese and zinc.

\section{SELECTED REFERENCES}

Balistrieri, L.S., Ortiz, R.F., Briggs, P.H., Elrick, K.A., and Edelmann, Patrick, 1996, Metal fluxes across the sediment-water interface in Terrace Reservoir, Colorado: U.S. Geological Survey Water-Resources Investigations Report 96-040, 83 p.

Boyles, J.M., Cain, Doug, Alley, W., and Klusman, R.W., 1974, Impact of Argo Tunnel acid mine drainage, Clear Creek County, Colorado, in Proceedings - Water Resources Problems Related to Mining: American Water Resources Association, Proceedings 18, p. 41-53.

Cain, Doug, 1995, Factors affecting surface-water quality in the Alamosa River Basin, south-central Colorado, in Posey, H.H., Pendleton, J.A., and Van Zyl, D., eds., Proceedings _ Summitville Forum '95: Denver, Colorado Geological Survey Special Publication 38, p. 159.

Church, S.E., 1993, Geochemical and lead-isotopic studies of stream and river sediments, Alamosa River Basin, Colorado: U.S. Geological Survey Open-File Report 95-250, $73 \mathrm{p}$. 
Driver, N.E., and Tasker, G.D., 1988, Techniques for estimation of storm-runoff loads, volumes, and selected constituent concentrations in urban watersheds in the United States: U.S. Geological Survey Open-File Report 88-191, 80 p.

Dzombak, D.A., and Morel, F.M.M., 1987, Adsorption of inorganic pollutants in aquatic systems: Journal of Hydraulic Engineering, v. 113, p. 430-475.

Edwards, T.K., and Glysson, G.D., 1988, Field methods for measurement of fluvial sediment: U.S. Geological Survey Open-File Report 86-531, 118 p.

Hamilton, J.L., 1989, Investigation of water supply for a private residence southwest of Monte Vista, Rio Grande County, Colorado, in Water in the valley, a 1989 perspective on water supplies, issues, and solutions in the San Luis Valley, Colorado: Colorado Ground Water Association, eighth annual field trip, August 19-20, 1989, p. 262-267.

Helsel, D.R., and Cohn, T.A., 1988, Estimation of descriptive statistics for multiple censored water quality data: Water Resources Research, v. 24, no. 12, p. 1997-2004.

Hem, J.D., 1977, Study and interpretation of the chemical characteristics of natural water ( $3 \mathrm{~d}$ ed.): U.S. Geological Survey Water-Supply Paper 2254, $263 \mathrm{p}$

Horowitz, A.J., 1991, A primer on sediment-trace element chemistry: Chelsea, Mich., Lewis Publishers, Inc., $136 \mathrm{p}$.

Horowitz, A.J., Lum, K.R., Garbarino, J.R., Hall, G.E.M., Lemieux, C., and Demas, C.R., 1996, Problems associated with using filtration to define dissolved trace element concentrations in natural waters: Environmental Science and Technology, v. 30, p. 954-963.

Iman, R.L., and Conover, W.J., 1983, A modern approach to statistics: New York, Wiley, 497 p.

Kimball, B.A., Callender, E., and Axtmann, E.V., 1995, Effects of colloids on metal transport in a river receiving acid mine drainage, upper Arkansas River, Colorado, U.S.A.: Applied Geochemistry, v. 10, p. 285-306.

King, T.V.V., ed., 1995, Environmental considerations of active and abandoned mine lands: U.S. Geological Survey Bulletin 2220, 38 p.

Kirkham, R.M., Lovekin, J.R., and Sares, M.A., 1995, Sources of acidity and heavy metals in the Alamosa River Basin outside of the Summitville mining area, Colorado, in Posey, H.H., Pendleton, J.A., and Van Zyl, D., eds., Proceedings-Summitville Forum '95: Denver, Colorado Geological Survey Special Publication 38, p. 42-57.
Miller, W.M., and McHugh, J.B., 1994, Natural acid drainage from altered areas within and adjacent to the upper Alamosa River Basin, Colorado: U.S. Geological Survey Open-File Report 94-144, $47 \mathrm{p}$.

Miller, S.H., and Van Zyl, D., 1995, Summitville site water quality characterization and modeling, Colorado, in Posey, H.H., Pendleton, J.A., and Van Zyl, D., eds., Proceedings—Summitville Forum '95: Denver, Colorado Geological Survey Special Publication 38, p. $75-86$.

Moran, R.E., and Wentz, D.A., 1974, Effects of metalmine drainage on water quality in selected areas of Colorado, 1972-73: Denver, Colorado Board Water Resources Circular 25, $250 \mathrm{p}$.

Morrison and Knudsen Corporation, and ICF Keiser Engineers, 1994, Summitville Mine site-Ecological risk assessment work plan.

Mueller, Mary, and Mueller, T.A., 1995, Surface water quality of the Alamosa River and selected tributaries, 1972 to 1994, in Posey, H.H., Pendleton, J.A., and Van Zyl, D., eds., Proceedings-Summitville Forum '95: Denver, Colorado Geological Survey Special Publication 38, p. 192-214.

Mueller, D.K., and Ruddy, B.C., 1992, Limnological characteristics, nutrient loading and limitation, and potential sources of taste and odor problems in Standley Lake, Colorado: U.S. Geological Survey Water-Resources Investigations Report 92-4053, $55 \mathrm{p}$.

Ortiz, R.F., von Guerard, P.B., and Walton-Day, Katherine, 1995, Effect of a localized rainstorm on the water quality of the Alamosa River upstream from Terrace Reservoir, south-central Colorado, August 9-10, 1993, in Posey, H.H., Pendleton, J.A., and Van Zyl, D., eds., Proceedings —Summitville Forum '95: Denver, Colorado Geological Survey Special Publication 38, p. $178-182$.

Plumlee, G.S., and Edelmann, Patrick, 1995, An update on U.S. Geological Survey studies of the Summitville Mine and its downstream environmental effects: U.S. Geological Survey Open-File Report 95-23, $10 \mathrm{p}$.

Posey, H.H., Pendleton, J.A., and Van Zyl, D., eds., 1995, Proceedings - Summitville Forum '95: Denver, Colorado Geological Survey Special Publication 38, $375 \mathrm{p}$.

SAS Institute Inc., 1985, SAS user's guide-Statistics (version 6, first edition): Cary, N.C., SAS Institute Inc., $560 \mathrm{p}$. 
Scheider, W.A., Moss, J.J., and Dillon, P.J., 1979, Measurement and uses of hydraulic and nutrient budgets-Proceedings, national conference on lake restoration, Minneapolis, Minn., August 22-24, 1978: U.S. Environmental Protection Agency Report EPA 440/5-79-001, p. 77-83.

Stogner, R.W., Sr., Edelmann, Patrick, and Walton-Day, Katherine, in press, Physical and chemical characteristics of Terrace Reservoir, Conejos County, Colorado, May 1994 through May 1995: U.S. Geological Survey Water-Resources Investigations Report 96-4150.

Tobin, R.L., 1993, Sediment transport and water-quality characteristics and loads, White River, northwestern Colorado, water years 1975-88:

U.S. Geological Survey Water-Resources Investigations Report 92-4031.

U.S. Environmental Protection Agency, 1991, Guidance manual for the preparation of NPDES permit application for storm water discharges associated with industrial activity: U.S. Environmental Protection Agency, EPA-505/8-91-002, 81 p.

1993, Summitville Mine removal action, site summary: Denver, Colo.
Walton-Day, Katherine, Ortiz, R.F., and von Guerard, P.B., 1995, Sources of water having low $\mathrm{pH}$ and elevated metal concentrations in the upper Alamosa River from the headwaters to the outlet of Terrace Reservoir, south-central Colorado, Apri-September 1993, in Posey, H.H., Pendleton, J.A., and Van Zyl, D., eds., Proceedings - Summitville Forum '95: Colorado Geological Survey Special Publication 38, p. 160-170.

Ward, E.C., and Walton-Day, Katherine, 1995, Seasonal variations in water quality on Wightman Fork of the Alamosa River, 1993, in Posey, H.H., Pendleton, J.A., and Van Zyl, D., eds., Proceedings - Summitville Forum '95: Denver, Colorado Geological Survey Special Publication 38, p. 183-190.

Ward, J.R., and Harr, C.A., eds., 1990, Methods for collection and processing of surface-water and bedmaterial samples for physical and chemical analyses: U.S. Geological Survey Open-File Report 90-140, $71 \mathrm{p}$.

Watts, K.R., in press, Bathymetric surface and storage capacity of Terrace Reservoir, Conejos County, Colorado, July-August 1994: U.S. Geological Survey Water-Resources Investigations Report 96-4027. 

SUPPLEMENTAL DATA 

Table 6. Estimated daily dissolved-metal loads and standard errors for sites AR34.5 and AR31.0, April 1994 through March 1995

[Loads and standard errors are in pounds per day; <, less than; --, no data]

\begin{tabular}{|c|c|c|c|c|c|c|c|c|c|c|c|c|c|}
\hline \multirow[b]{2}{*}{ Site } & \multirow[b]{2}{*}{ Date } & \multicolumn{2}{|c|}{ Aluminum } & \multicolumn{2}{|c|}{ Iron } & \multicolumn{2}{|c|}{ Copper } & \multicolumn{2}{|c|}{ Cadmium } & \multicolumn{2}{|c|}{ Menganese } & \multicolumn{2}{|c|}{ Zine } \\
\hline & & Load & $\begin{array}{l}\text { Standard } \\
\text { error }\end{array}$ & Load & $\begin{array}{l}\text { Standard } \\
\text { error }\end{array}$ & Load & $\begin{array}{l}\text { Standard } \\
\text { error }\end{array}$ & Load & $\begin{array}{l}\text { Standard } \\
\text { error }\end{array}$ & Load & $\begin{array}{l}\text { Standard } \\
\text { error }\end{array}$ & Load & $\begin{array}{l}\text { Standard } \\
\text { error }\end{array}$ \\
\hline$\overline{\text { AR34.5 }}$ & $04 / 01 / 94$ & 13 & 2.4 & 41 & 1.9 & 2.4 & 0.3 & $<0.1$ & $<0.1$ & 52 & 6.6 & 7.9 & 1.5 \\
\hline AR31.0 & $04 / 01 / 94$ & 8.4 & 0.6 & 8.5 & 3.7 & 4.1 & 0.8 & 0.1 & $<0.1$ & 78 & 2.3 & 16 & 1.4 \\
\hline AR34.5 & $04 / 02 / 94$ & 14 & 2.5 & 43 & 2.0 & 2.6 & 0.3 & $<0.1$ & $<0.1$ & 54 & 6.9 & 8.4 & 1.5 \\
\hline AR31.0 & $04 / 02 / 94$ & 8.8 & 0.6 & 8.9 & 3.9 & 4.4 & 0.9 & 0.1 & $<0.1$ & 83 & 2.4 & 17 & 1.5 \\
\hline AR34.5 & $04 / 03 / 94$ & 13 & 2.3 & 40 & 1.9 & 2.4 & 0.3 & $<0.1$ & $<0.1$ & 50 & 6.4 & 7.7 & 1.4 \\
\hline AR31.0 & $04 / 03 / 94$ & 8.1 & 0.6 & 8.2 & 3.6 & 4.0 & 0.8 & 0.1 & $<0.1$ & 76 & 2.2 & 16 & 1.4 \\
\hline AR34.5 & $04 / 04 / 94$ & 14 & 2.5 & 43 & 2.0 & 2.6 & 0.3 & $<0.1$ & $<0.1$ & 54 & 6.9 & 8.4 & 1.5 \\
\hline AR31.0 & $04 / 04 / 94$ & 8.8 & 0.6 & 8.9 & 3.9 & 4.4 & 0.9 & 0.1 & $<0.1$ & 83 & 2.4 & 17 & 1.5 \\
\hline AR34.5 & $04 / 05 / 94$ & 13 & 2.5 & 42 & 2.0 & 2.5 & 0.3 & $<0.1$ & $<0.1$ & 53 & 6.8 & 8.1 & 1.5 \\
\hline AR31.0 & $04 / 05 / 94$ & 8.6 & 0.6 & 8.7 & 3.8 & 4.3 & 0.9 & 0.1 & $<0.1$ & 81 & 2.4 & 16 & 1.5 \\
\hline AR34.5 & $04 / 06 / 94$ & 11 & 2.1 & 35 & 1.7 & 2.1 & 0.3 & $<0.1$ & $<0.1$ & 44 & 5.7 & 6.8 & 1.2 \\
\hline AR31.0 & $04 / 06 / 94$ & 7.2 & 0.5 & 7.3 & 3.2 & 3.6 & 0.7 & 0.1 & $<0.1$ & 67 & 2.0 & 14 & 1.2 \\
\hline AR34.5 & $04 / 07 / 94$ & 12 & 2.2 & 37 & 1.8 & 2.2 & 0.3 & $<0.1$ & $<0.1$ & 47 & 6.0 & 7.3 & 1.3 \\
\hline AR31.0 & $04 / 07 / 94$ & 7.7 & 0.5 & 7.8 & 3.4 & 3.8 & 0.8 & 0.1 & $<0.1$ & 72 & 2.1 & 15 & 1.3 \\
\hline AR34.5 & $04 / 08 / 94$ & 10 & 1.9 & 33 & 1.6 & 2.0 & 0.2 & $<0.1$ & $<0.1$ & 42 & 5.3 & 6.4 & 1.2 \\
\hline AR31.0 & $04 / 08 / 94$ & 6.7 & 0.5 & 6.8 & 3.0 & 3.3 & 0.7 & 0.1 & $<0.1$ & 63 & 1.9 & 13 & 1.2 \\
\hline AR34.5 & $04 / 09 / 94$ & 10 & 1.9 & 33 & 1.6 & 2.0 & 0.2 & $<0.1$ & $<0.1$ & 42 & 5.3 & 6.4 & 1.2 \\
\hline AR31.0 & $04 / 09 / 94$ & 6.7 & 0.5 & 6.8 & 3.0 & 3.3 & 0.7 & 0.1 & $<0.1$ & 63 & 1.9 & 13 & 1.2 \\
\hline AR34.5 & $04 / 10 / 94$ & 10 & 1.9 & 32 & 1.5 & 1.9 & 0.2 & $<0.1$ & $<0.1$ & 40 & 5.1 & 6.2 & 1.1 \\
\hline AR31.0 & $04 / 10 / 94$ & 6.5 & 0.5 & 6.6 & 2.9 & 3.2 & 0.7 & 0.1 & $<0.1$ & 61 & 1.8 & 12 & 1.1 \\
\hline AR34.5 & $04 / 11 / 94$ & 9.3 & 1.7 & 29 & 1.4 & 1.8 & 0.2 & $<0.1$ & $<0.1$ & 37 & 4.8 & 5.7 & 1.0 \\
\hline AR31.0 & $04 / 11 / 94$ & 6.0 & 0.4 & 6.1 & 2.7 & 3.0 & 0.6 & 0.1 & $<0.1$ & 57 & 1.7 & 12 & 1.0 \\
\hline AR34.5 & $04 / 12 / 94$ & 8.6 & 1.6 & 27 & 1.3 & 1.6 & 0.2 & $<0.1$ & $<0.1$ & 34 & 4.4 & 5.3 & 1.0 \\
\hline AR31.0 & $04 / 12 / 94$ & 5.6 & 0.4 & 5.6 & 2.5 & 2.8 & 0.6 & 0.1 & $<0.1$ & 52 & 1.5 & 11 & 1.0 \\
\hline AR34.5 & $04 / 13 / 94$ & 10 & 1.9 & 32 & 1.5 & 1.9 & 0.2 & $<0.1$ & $<0.1$ & 40 & 5.1 & 6.2 & 1.1 \\
\hline AR31.0 & $04 / 13 / 94$ & 6.5 & 0.5 & 6.6 & 2.9 & 3.2 & 0.7 & 0.1 & $<0.1$ & 61 & 1.8 & 12 & 1.1 \\
\hline AR34.5 & $04 / 14 / 94$ & 13 & 2.4 & 41 & 1.9 & 2.4 & 0.3 & $<0.1$ & $<0.1$ & 52 & 6.6 & 7.9 & 1.5 \\
\hline AR31.0 & $04 / 14 / 94$ & 8.4 & 0.6 & 8.5 & 3.7 & 4.1 & 0.8 & 0.1 & $<0.1$ & 78 & 2.3 & 16 & 1.4 \\
\hline AR34.5 & $04 / 15 / 94$ & 14 & 2.7 & 45 & 2.2 & 2.7 & 0.3 & $<0.1$ & $<0.1$ & 57 & 7.3 & 8.8 & 1.6 \\
\hline AR31.0 & $04 / 15 / 94$ & 9.3 & 0.7 & 9.4 & 4.1 & 4.6 & 0.9 & 0.1 & $<0.1$ & 87 & 2.6 & 18 & 1.6 \\
\hline AR34.5 & $04 / 16 / 94$ & 19 & 3.5 & 60 & 2.8 & 3.6 & 0.4 & $<0.1$ & $<0.1$ & 76 & 9.7 & 12 & 2.1 \\
\hline AR31.0 & $04 / 16 / 94$ & 12 & 0.9 & 13 & 5.4 & 6.1 & 1.2 & 0.2 & $<0.1$ & 115 & 3.4 & 24 & 2.1 \\
\hline AR34.5 & $04 / 17 / 94$ & 28 & 5.3 & 89 & 4.2 & 5.3 & 0.7 & $<0.2$ & $<0.1$ & 113 & 14 & 17 & 3.2 \\
\hline AR31.0 & $04 / 17 / 94$ & 18 & 1.3 & 19 & 8.1 & 9.1 & 1.8 & 0.3 & $<0.1$ & 172 & 5.1 & 35 & 3.1 \\
\hline AR34.5 & $04 / 18 / 94$ & 37 & 6.9 & 118 & 5.6 & 7.0 & 0.9 & $<0.3$ & $<0.1$ & 149 & 19 & 23 & 4.2 \\
\hline AR31.0 & $04 / 18 / 94$ & 24 & 1.7 & 25 & 11 & 12 & 2.4 & 0.4 & $<0.1$ & 226 & 6.7 & 46 & 4.1 \\
\hline AR34.5 & $04 / 19 / 94$ & 41 & 7.6 & 129 & 6.1 & 7.7 & 0.9 & $<0.3$ & $<0.1$ & 163 & 21 & 25 & 4.6 \\
\hline AR31.0 & $04 / 19 / 94$ & 26 & 1.9 & 27 & 12 & 13 & 2.7 & 0.4 & $<0.1$ & 248 & 7.3 & 51 & 4.5 \\
\hline AR34.5 & $04 / 20 / 94$ & 46 & 8.5 & 145 & 6.9 & 8.7 & 1.1 & $<0.3$ & $<0.1$ & 183 & 23 & 28 & 5.2 \\
\hline AR31.0 & $04 / 20 / 94$ & 32 & 2.2 & 32 & 14 & 16 & 3.2 & 0.5 & $<0.1$ & 296 & 8.7 & 60 & 5.4 \\
\hline
\end{tabular}


Table 6. Estimated daily dissolved-metal loads and standard errors for sites AR34.5 and AR31.0, April 1994 through March 1995-Continued

[Loads and standard errors are in pounds per day; <, less than; --, no data]

\begin{tabular}{|c|c|c|c|c|c|c|c|c|c|c|c|c|c|}
\hline \multirow[b]{2}{*}{ Site } & \multirow[b]{2}{*}{ Date } & \multicolumn{2}{|c|}{ Aluminum } & \multicolumn{2}{|c|}{ Iron } & \multicolumn{2}{|c|}{ Copper } & \multicolumn{2}{|c|}{ Cadmlum } & \multicolumn{2}{|c|}{ Manganese } & \multicolumn{2}{|c|}{ Zlnc } \\
\hline & & Load & $\begin{array}{l}\text { Standard } \\
\text { error }\end{array}$ & Load & $\begin{array}{l}\text { Standard } \\
\text { error }\end{array}$ & Load & $\begin{array}{l}\text { Standard } \\
\text { error }\end{array}$ & Load & $\begin{array}{l}\text { Standard } \\
\text { error }\end{array}$ & Load & $\begin{array}{l}\text { Standard } \\
\text { error }\end{array}$ & Load & $\begin{array}{l}\text { Standard } \\
\text { error }\end{array}$ \\
\hline$\overline{\text { AR34.5 }}$ & $04 / 21 / 94$ & 59 & 11 & 185 & 8.8 & 11 & 1.4 & $<0.4$ & $<0.1$ & 235 & 30 & 36 & 6.6 \\
\hline AR31.0 & $04 / 21 / 94$ & 32 & 2.2 & 32 & 14 & 16 & 3.2 & 0.5 & $<0.1$ & 298 & 8.8 & 61 & 5.4 \\
\hline AR34.5 & $04 / 22 / 94$ & 71 & 13 & 223 & 11 & 13 & 1.6 & $<0.5$ & $<0.1$ & 282 & 36 & 43 & 7.9 \\
\hline AR31.0 & $04 / 22 / 94$ & 49 & 3.4 & 49 & 22 & 24 & 4.9 & 0.7 & 0.1 & 455 & 13 & 93 & 8.3 \\
\hline AR34.5 & $04 / 23 / 94$ & 93 & 17 & 294 & 14 & 18 & 2.2 & $<0.7$ & $<0.1$ & 372 & 48 & 57 & 11 \\
\hline AR31.0 & $04 / 23 / 94$ & 59 & 4.2 & 60 & 26 & 29 & 5.9 & 0.9 & 0.1 & 553 & 16 & 113 & 10 \\
\hline AR34.5 & $04 / 24 / 94$ & 96 & 18 & 303 & 14 & 18 & 2.2 & $<0.7$ & $<0.1$ & 383 & 49 & 59 & 11 \\
\hline AR31.0 & $04 / 24 / 94$ & 59 & 4.2 & 60 & 26 & 29 & 5.9 & 0.9 & 0.1 & 553 & 16 & 113 & 10 \\
\hline AR34.5 & $04 / 25 / 94$ & 75 & 14 & 237 & 11 & 14 & 1.7 & $<0.6$ & $<0.1$ & 300 & 38 & 46 & 8.5 \\
\hline AR31.0 & $04 / 25 / 94$ & 59 & 4.2 & 60 & 26 & 29 & 5.9 & 0.9 & 0.1 & 553 & 16 & 113 & 10 \\
\hline AR34.5 & $04 / 26 / 94$ & 57 & 11 & 178 & 8.5 & 11 & 1.3 & $<0.4$ & $<0.1$ & 226 & 29 & 35 & 6.4 \\
\hline AR31.0 & $04 / 26 / 94$ & 45 & 3.2 & 46 & 20 & 22 & 4.5 & 0.7 & 0.1 & 422 & 13 & 86 & 7.7 \\
\hline AR34.5 & $04 / 27 / 94$ & 46 & 8.6 & 146 & 6.9 & 8.7 & 1.1 & $<0.3$ & $<0.1$ & 184 & 24 & 28 & 5.2 \\
\hline AR31.0 & $04 / 27 / 94$ & 37 & 2.6 & 37 & 16 & 18 & 3.7 & 0.5 & 0.1 & 346 & 10 & 71 & 6.3 \\
\hline AR34.5 & $04 / 28 / 94$ & 39 & 7.2 & 122 & 5.8 & 7.3 & 0.9 & $<0.3$ & $<0.1$ & 154 & 20 & 24 & 4.4 \\
\hline AR31.0 & $04 / 28 / 94$ & 29 & 2.0 & 29 & 13 & 14 & 2.9 & 0.4 & $<0.1$ & 270 & 8.0 & 55 & 4.9 \\
\hline AR34.5 & $04 / 29 / 94$ & 37 & 6.9 & 117 & 5.6 & 7.0 & 0.9 & $<0.3$ & $<0.1$ & 149 & 19 & 23 & 4.2 \\
\hline AR31.0 & $04 / 29 / 94$ & 25 & 1.7 & 25 & 11 & 12 & 2.5 & 0.4 & $<0.1$ & 231 & 6.8 & 47 & 4.2 \\
\hline AR34.5 & $04 / 30 / 94$ & 33 & 6.1 & 103 & 4.9 & 6.2 & 0.8 & $<0.2$ & $<0.1$ & 130 & 17 & 20 & 3.7 \\
\hline AR31.0 & $04 / 30 / 94$ & 25 & 1.7 & 25 & 11 & 12 & 2.5 & 0.4 & $<0.1$ & 231 & 6.8 & 47 & 4.2 \\
\hline AR34.5 & $05 / 01 / 94$ & 34 & 6.3 & 106 & 5.1 & 6.4 & 0.8 & $<0.3$ & $<0.1$ & 134 & 17 . & 21 & 3.8 \\
\hline AR31.0 & $05 / 01 / 94$ & 25 & 1.7 & 25 & 11 & 12 & 2.5 & 0.4 & $<0.1$ & 231 & 6.8 & 47 & 4.2 \\
\hline AR34.5 & $05 / 02 / 94$ & 31 & 5.7 & 97 & 4.6 & 5.8 & 0.7 & $<0.2$ & $<0.1$ & 123 & 16 & 19 & 3.5 \\
\hline AR31.0 & $05 / 02 / 94$ & 27 & 1.9 & 27 & 12 & 13 & 2.7 & 0.4 & $<0.1$ & 250 & 7.4 & 51 & 4.6 \\
\hline AR34.5 & $05 / 03 / 94$ & 30 & 5.5 & 94 & 4.5 & 5.6 & 0.7 & $<0.2$ & $<0.1$ & 119 & 15 & 18 & 3.3 \\
\hline AR31.0 & $05 / 03 / 94$ & 28 & 2.0 & 29 & 13 & 14.1 & 2.8 & 0.4 & $<0.1$ & 265 & 7.8 & 54 & 4.8 \\
\hline AR34.5 & $05 / 04 / 94$ & 32.2 & 6.0 & 102 & 4.8 & 6.1 & 0.7 & $<0.2$ & $<0.1$ & 129 & 17 & 20 & 3.6 \\
\hline AR31.0 & $05 / 04 / 94$ & 28 & 2.0 & 29 & 13 & 14 & 2.8 & 0.4 & $<0.1$ & 265 & 7.8 & 54 & 4.8 \\
\hline AR34.5 & $05 / 05 / 94$ & 52 & 9.7 & 165 & 7.8 & 9.9 & 1.2 & $<0.4$ & $<0.1$ & 209 & 27 & 32 & 5.9 \\
\hline AR31.0 & $05 / 05 / 94$ & 36 & 2.5 & 37 & 16 & 18 & 3.6 & 0.5 & 0.1 & 337 & 10 & 69 & 6.2 \\
\hline AR34.5 & $05 / 06 / 94$ & 87 & 16 & 273 & 13 & 16 & 2.0 & $<0.7$ & $<0.1$ & 346 & 44 & 53 & 9.8 \\
\hline AR31.0 & $05 / 06 / 94$ & 56 & 3.9 & 57 & 25 & 28 & 5.6 & 0.8 & 0.1 & 524 & 16 & 107 & 9.6 \\
\hline AR34.5 & $05 / 07 / 94$ & 110 & 20 & 347 & 17 & 21 & 2.6 & $<0.8$ & $<0.1$ & 439 & 56 & 68 & 12 \\
\hline AR31.0 & $05 / 07 / 94$ & 65 & 4.6 & 66 & 29 & 33 & 6.6 & 1.0 & 0.1 & 614 & 18 & 125 & 11 \\
\hline AR34.5 & $05 / 08 / 94$ & 109 & 50 & 345 & 16 & 54 & 2.5 & $<0.8$ & $<0.1$ & 436 & 56 & 67 & 12 \\
\hline AR31.0 & $05 / 08 / 94$ & 72 & 5.1 & 73 & 32 & 36 & 7.2 & 1.1 & 0.1 & 674 & 20 & 138 & 12 \\
\hline AR34.5 & $05 / 09 / 94$ & 124 & 23 & 392 & 19 & 24 & 2.9 & $<0.9$ & $<0.1$ & 496 & 63 & 76 & 14 \\
\hline AR31.0 & $05 / 09 / 94$ & 90 & 6.4 & 92 & 40 & 45 & 9.0 & 1.3 & 0.1 & 846 & 25 & 173 & 16 \\
\hline AR34.5 & $05 / 10 / 94$ & 93 & 17 & 293 & 14 & 18 & 2.2 & $<0.7$ & $<0.1$ & 370 & 47 & 57 & 10 \\
\hline AR31.0 & $05 / 10 / 94$ & 90 & 6.3 & 91 & 40 & 45 & 9.0 & 1.3 & 0.1 & 840 & 25 & 171 & 15 \\
\hline AR34.5 & $05 / 11 / 94$ & 86 & 16 & 270 & 13 & 16 & 2.0 & $<0.6$ & $<0.1$ & 342 & 44 & 53 & 9.6 \\
\hline AR31.0 & $05 / 11 / 94$ & 71 & 5.0 & 72 & 31 & 35 & 7.1 & 1.0 & 0.1 & 666 & 20 & 136 & 12 \\
\hline
\end{tabular}


Table 6. Estimated daily dissolved-metal loads and standard errors for sites AR34.5 and AR31.0, April 1994 through March 1995-Continued

[Loads and standard errors are in pounds per day; <, less than; --, no data]

\begin{tabular}{|c|c|c|c|c|c|c|c|c|c|c|c|c|c|}
\hline \multirow[b]{2}{*}{ Site } & \multirow[b]{2}{*}{ Date } & \multicolumn{2}{|c|}{ Aluminum } & \multicolumn{2}{|c|}{ Iron } & \multicolumn{2}{|c|}{ Copper } & \multicolumn{2}{|c|}{ Cadmium } & \multicolumn{2}{|c|}{ Manganese } & \multicolumn{2}{|c|}{ Zinc } \\
\hline & & Load & $\begin{array}{l}\text { Standard } \\
\text { error }\end{array}$ & Load & $\begin{array}{l}\text { Standard } \\
\text { error }\end{array}$ & Load & $\begin{array}{l}\text { Standard } \\
\text { error }\end{array}$ & Load & $\begin{array}{l}\text { Standard } \\
\text { error }\end{array}$ & Load & $\begin{array}{l}\text { Standard } \\
\text { error }\end{array}$ & Load & $\begin{array}{l}\text { Standard } \\
\text { error }\end{array}$ \\
\hline$\overline{\text { AR34.5 }}$ & $05 / 12 / 94$ & 118 & 22 & 372 & 18 & 22 & 2.7 & $<0.9$ & $<0.1$ & 471 & 60 & 73 & 13 \\
\hline AR31.0 & $05 / 12 / 94$ & 64 & 4.5 & 64 & 28 & 62 & 6.4 & 0.9 & 0.1 & 596 & 18 & 122 & 11 \\
\hline AR34.5 & $05 / 13 / 94$ & 155 & 29 & 489 & 23 & 29 & 3.6 & $<1.2$ & $<0.1$ & 619 & 79 & 95 & 18 \\
\hline AR31.0 & $05 / 13 / 94$ & 112 & 14 & 231 & 23 & 28 & 2.9 & 1.0 & 0.1 & 519 & 25 & 129 & 64 \\
\hline AR34.5 & $05 / 14 / 94$ & 176 & 33 & 555 & 26 & 33 & 4.1 & $<1.3$ & $<0.1$ & 702 & 90 & 108 & 20 \\
\hline AR31.0 & $05 / 14 / 94$ & 143 & 17 & 295 & 29 & 35 & 3.7 & 1.3 & 0.1 & 662 & 31 & 165 & 81 \\
\hline AR34.5 & $05 / 15 / 94$ & 194 & 36 & 611 & 29 & 37 & 4.5 & $<1.5$ & $<0.1$ & 774 & 99 & 119 & 22 \\
\hline AR31.0 & $05 / 15 / 94$ & 174 & 21 & 358 & 35 & 43 & 4.5 & 1.6 & 0.1 & 803 & 38 & 200 & 99 \\
\hline AR34.5 & $05 / 16 / 94$ & 206 & 38 & 648 & 31 & 39 & 4.8 & $<1.5$ & $<0.1$ & 821 & 105 & 126 & 23 \\
\hline AR31.0 & $05 / 16 / 94$ & 187 & 23 & 386 & 38 & 46 & 4.9 & 1.7 & 0.2 & 866 & 41 & 216 & 106 \\
\hline AR34.5 & $05 / 17 / 94$ & 234 & 44 & 738 & 35 & 44 & 5.4 & $<1.8$ & $<0.1$ & 934 & 119 & 144 & 26 \\
\hline AR31.0 & $05 / 17 / 94$ & 203 & 24 & 419 & 41 & 50 & 5.3 & 1.8 & 0.2 & 940 & 44 & 234 & 116 \\
\hline AR34.5 & $05 / 18 / 94$ & 243 & 45 & 766 & 36 & 46 & 5.6 & $<1.8$ & $<0.1$ & 970 & 124 & 149 & 27 \\
\hline AR31.0 & $05 / 18 / 94$ & 215 & 26 & 442 & 43 & 53 & 5.6 & 1.9 & 0.2 & 993 & 47 & 248 & 122 \\
\hline AR34.5 & $05 / 19 / 94$ & 261 & 49 & 822 & 39 & 49 & 6.1 & $<2.0$ & $<0.1$ & 1,040 & 133 & 160 & 29 \\
\hline AR31.0 & $05 / 19 / 94$ & 216 & 26 & 444 & 44 & 53 & 5.6 & 1.9 & 0.2 & 996 & 48 & 248 & 122 \\
\hline AR34.5 & $05 / 20 / 94$ & 262 & 49 & 827 & 39 & 50 & 6.1 & $<2.0$ & $<0.1$ & 1,050 & 134 & 161 & 30 \\
\hline AR31.0 & $05 / 20 / 94$ & 216 & 26 & 444 & 44 & 53 & 5.6 & 1.9 & 0.2 & 998 & 47 & 249 & 123 \\
\hline AR34.5 & $05 / 21 / 94$ & 250 & 46 & 787 & 38 & 47 & 5.8 & $<1.9$ & $<0.1$ & 997 & 127 & 153 & 28 \\
\hline AR31.0 & $05 / 21 / 94$ & 216 & 26 & 444 & 44 & 53 & 5.6 & 1.9 & 0.2 & 996 & 47 & 248 & 122 \\
\hline AR34.5 & $05 / 22 / 94$ & 171 & - & 1,560 & -- & 171 & -- & $<1.9$ & - & 982 & -- & 325 & - \\
\hline AR31.0 & $05 / 22 / 94$ & 217 & 26 & 446 & 44 & 54 & 5.6 & 2.0 & 0.2 & 1,000 & 47 & 249 & 123 \\
\hline AR34.5 & $05 / 23 / 94$ & 184 & -- & 1,680 & -- & 183 & -- & $<2.1$ & - & 1,060 & -- & 350 & -- \\
\hline AR31.0 & $05 / 23 / 94$ & 240 & 29 & 494 & 48 & 59 & 6.3 & 2.2 & 0.2 & 1,110 & 53 & 277 & 136 \\
\hline AR34.5 & $05 / 24 / 94$ & 170 & - & 1,550 & - & 170 & -- & $<1.9$ & -- & 977 & -- & 324 & - \\
\hline AR31.0 & $05 / 24 / 94$ & 256 & 31 & 528 & 52 & 63 & 6.7 & 2.3 & 0.2 & 1,180 & 56 & 295 & 146 \\
\hline AR34.5 & $05 / 25 / 94$ & 145 & -- & 1,320 & - & 145 & - & $<1.7$ & - & 333 & -- & 276 & - \\
\hline AR31.0 & $05 / 25 / 94$ & 256 & 31 & 528 & 52 & 63 & 6.7 & 2.3 & 0.2 & 1,180 & 56 & 295 & 146 \\
\hline AR34.5 & $05 / 26 / 94$ & 125 & 27 & 1,620 & 153 & 282 & 46 & 2.9 & 0.4 & 805 & 50 & 625 & 33 \\
\hline AR31.0 & $05 / 26 / 94$ & 232 & 28 & 478 & 47 & 57 & 6.0 & 2.1 & 0.2 & 1,070 & 51 & 267 & 132 \\
\hline AR34.5 & $05 / 27 / 94$ & 111 & 24 & 1,440 & 136 & 251 & 41 & 2.5 & 0.4 & 715 & 44 & 289 & 30 \\
\hline AR31.0 & $05 / 27 / 94$ & 178 & 21 & 366 & 36 & 44 & 4.6 & 1.6 & 0.1 & 822 & 39 & 205 & 101 \\
\hline AR34.5 & $05 / 28 / 94$ & 129 & 28 & 1,670 & 157 & 291 & 48 & 3.0 & 0.4 & 829 & 52 & 335 & 34 \\
\hline AR31.0 & $05 / 28 / 94$ & 102 & -- & 220 & -- & 86 & -- & 1.5 & -- & 750 & -- & 441 & -- \\
\hline AR34.5 & $05 / 29 / 94$ & 169 & 36 & 2,200 & 207 & 382 & 63 & 3.9 & 0.6 & 1,090 & 68 & 440 & 45 \\
\hline AR31.0 & $05 / 29 / 94$ & 102 & - & 220 & -- & 56 & -- & 1.5 & - & 750 & -- & 441 & -- \\
\hline AR34.5 & $05 / 30 / 94$ & 215 & 46 & 2,790 & 262 & 484 & 80 & 4.9 & 0.7 & 1,380 & 86 & 558 & 57 \\
\hline AR31.0 & $05 / 30 / 94$ & 145 & - & 311 & -- & 122 & - & 2.2 & -- & 1,060 & - & 626 & - \\
\hline AR34.5 & $05 / 31 / 94$ & 228 & 49 & 2,960 & 278 & 514 & 84 & 5.2 & 0.7 & 1,470 & 91 & 593 & 61 \\
\hline AR31.0 & $05 / 31 / 94$ & 193 & -- & 416 & -- & 162 & - & 2.9 & - & 1,420 & - & 836 & -- \\
\hline AR34.5 & $06 / 01 / 94$ & 248 & 53 & 3,220 & 302 & 559 & 92 & 5.7 & 0.8 & 1,590 & 99 & 644 & 66 \\
\hline AR31.0 & $06 / 01 / 94$ & 195 & -- & 419 & -- & 164 & -- & 2.9 & -- & 1,430 & -- & 842 & -- \\
\hline
\end{tabular}


Table 6. Estimated daily dissolved-metal loads and standard errors for sites AR34.5 and AR31.0, April 1994 through March 1995-Continued

[Loads and standard errors are in pounds per day; <, less than; --, no data]

\begin{tabular}{|c|c|c|c|c|c|c|c|c|c|c|c|c|c|}
\hline \multirow[b]{2}{*}{ Site } & \multirow[b]{2}{*}{ Date } & \multicolumn{2}{|c|}{ Aluminum } & \multicolumn{2}{|c|}{ Iron } & \multicolumn{2}{|c|}{ Copper } & \multicolumn{2}{|c|}{ Cadmium } & \multicolumn{2}{|c|}{ Manganese } & \multicolumn{2}{|c|}{ Zinc } \\
\hline & & Load & $\begin{array}{l}\text { Standard } \\
\text { error }\end{array}$ & Load & $\begin{array}{l}\text { Standard } \\
\text { error }\end{array}$ & Load & $\begin{array}{l}\text { Standard } \\
\text { error }\end{array}$ & Load & $\begin{array}{l}\text { Standard } \\
\text { error }\end{array}$ & Load & $\begin{array}{l}\text { Standard } \\
\text { error }\end{array}$ & Load & $\begin{array}{l}\text { Standard } \\
\text { error }\end{array}$ \\
\hline$\overline{\text { AR34.5 }}$ & $06 / 02 / 94$ & 242 & 52 & 3,140 & 295 & 546 & 90 & 5.5 & $\overline{0.8}$ & 1,560 & 97 & 629 & 64 \\
\hline AR31.0 & $06 / 02 / 94$ & 170 & -- & 367 & - & 143 & -- & 2.6 & -- & 1,250 & -- & 737 & - \\
\hline AR34.5 & $06 / 03 / 94$ & 220 & 47 & 2,860 & 267 & 496 & 82 & 5.0 & 0.7 & 1,420 & 88 & 572 & 58 \\
\hline AR31.0 & $06 / 03 / 94$ & 158 & -- & 341 & -- & 133 & -- & 2.4 & -- & 1,160 & -- & 684 & -- \\
\hline AR34.5 & $06 / 04 / 94$ & 230 & 49 & 2,980 & 281 & 519 & 85 & 5.3 & 0.8 & 1,480 & 92 & 598 & 61 \\
\hline AR31.0 & $06 / 04 / 94$ & 152 & -- & 327 & -- & 128 & -- & 2.3 & -- & 1,120 & -- & 656 & -- \\
\hline AR34.5 & $06 / 05 / 94$ & 206 & 44 & 2,680 & 252 & 466 & 77 & 4.7 & 0.7 & 1,330 & 82 & 536 & 55 \\
\hline AR31.0 & $06 / 05 / 94$ & 160 & -- & 1,710 & -- & 941 & -- & 8.4 & -- & 1,340 & -- & 550 & -- \\
\hline AR34.5 & $06 / 06 / 94$ & 185 & 40 & 2,400 & 226 & 418 & 69 & 4.2 & 0.6 & 1,190 & 74 & 481 & 49 \\
\hline AR31.0 & $06 / 06 / 94$ & 153 & -- & 1,640 & -- & 903 & -- & 8.0 & -- & 1,290 & -- & 528 & -- \\
\hline AR34.5 & $06 / 07 / 94$ & 167 & 36 & 2,170 & 204 & 376 & 62 & 3.8 & 0.5 & 1,070 & 67 & 434 & 44 \\
\hline AR31.0 & $06 / 07 / 94$ & 126 & -- & 1,350 & -- & 744 & -- & 6.6 & -- & 1,060 & - & 435 & -- \\
\hline AR34.5 & $06 / 08 / 94$ & 1,630 & 665 & 10,800 & 1,180 & 3,590 & 490 & 7.3 & 1.1 & 1,490 & 176 & 1,010 & 35 \\
\hline AR31.0 & $06 / 08 / 94$ & 108 & -- & 1,150 & -- & 636 & -- & 5.7 & -- & 908 & -- & 372 & -- \\
\hline AR34.5 & $06 / 09 / 94$ & 1,550 & 633 & 10,300 & 1,130 & 3,420 & 467 & 6.9 & 1.1 & 1,420 & 168 & 961 & 81 \\
\hline AR31.0 & $06 / 09 / 94$ & 103 & - & 1,100 & -- & 608 & -- & 5.4 & -- & 868 & - & 356 & -- \\
\hline AR34.5 & $06 / 10 / 94$ & 1,510 & 616 & 10,000 & 1,100 & 3,330 & 454 & 6.8 & 1.0 & 1,380 & 163 & 936 & 79 \\
\hline AR31.0 & $06 / 10 / 94$ & 103 & - & 1,100 & -- & 608 & -- & 5.4 & -- & 868 & - & 356 & -- \\
\hline AR34.5 & $06 / 11 / 94$ & 1,390 & 568 & 9,230 & 1,010 & 3,060 & 419 & 6.2 & 1.0 & 1,270 & 150 & 862 & 73 \\
\hline AR31.0 & $06 / 11 / 94$ & 514 & 80 & 3,570 & 382 & 1,700 & 164 & 4.0 & 0.2 & 985 & 46 & 428 & 26 \\
\hline AR34.5 & $06 / 12 / 94$ & 1,240 & 505 & 8,220 & 899 & 2,730 & 373 & 5.5 & 0.9 & 1,130 & 134 & 767 & 65 \\
\hline AR31.0 & $06 / 12 / 94$ & 514 & 80 & 3,570 & 382 & 1,700 & 164 & 4.0 & 0.2 & 985 & 46 & 528 & 56 \\
\hline AR34.5 & $06 / 13 / 94$ & 1,300 & 529 & 8,600 & 940 & 2,850 & 390 & 5.8 & 0.9 & 1,180 & 140 & 802 & 68 \\
\hline AR31.0 & $06 / 13 / 94$ & 514 & 80 & 3,570 & 382 & 1,700 & 164 & 4.0 & 0.2 & 985 & 46 & 528 & 26 \\
\hline AR34.5 & $06 / 14 / 94$ & 1,280 & 524 & 8,520 & 321 & 2,830 & 386 & 5.7 & 0.9 & 1,170 & 138 & 795 & 67 \\
\hline AR31.0 & $06 / 14 / 94$ & 514 & 80 & 3,570 & 382 & 1,700 & 164 & 4.0 & 0.2 & 985 & 46 & 528 & 26 \\
\hline AR34.5 & $06 / 15 / 94$ & 1,150 & 468 & 7,610 & 832 & 2,520 & 345 & 5.1 & 0.8 & 1,050 & 124 & 710 & 60 \\
\hline AR31.0 & $06 / 15 / 94$ & 514 & 80 & 3,570 & 382 & 1,700 & 164 & 4.0 & 0.2 & 985 & 46 & 528 & 26 \\
\hline AR34.5 & $06 / 16 / 94$ & 1,010 & 413 & 6,720 & 734 & 2,230 & 304 & 4.5 & 0.7 & 926 & 109 & 627 & 53 \\
\hline AR31.0 & $06 / 16 / 94$ & 473 & 73 & 3,290 & 352 & 1,560 & 151 & 3.6 & 0.2 & 907 & 42 & 486 & 24 \\
\hline AR34.5 & $06 / 17 / 94$ & 934 & 381 & 6,200 & 678 & 2,060 & 281 & 4.2 & 0.6 & 855 & 101 & 579 & 49 \\
\hline AR31.0 & $06 / 17 / 94$ & 423 & 66 & 2,940 & 315 & 1,400 & 135 & 3.3 & 0.1 & 812 & 38 & 435 & 21 \\
\hline AR34.5 & $06 / 18 / 94$ & 874 & 357 & 5,800 & 634 & 1,930 & 263 & 3.9 & 0.6 & 800 & 94 & 542 & 46 \\
\hline AR31.0 & $06 / 18 / 94$ & 368 & 57 & 2,560 & 274 & 1,220 & 118 & 2.8 & 0.1 & 707 & 33 & 379 & 18 \\
\hline AR34.5 & $06 / 19 / 94$ & 153 & - & 2,910 & -- & 718 & -- & 2.0 & -- & 648 & - & 310 & -- \\
\hline AR31.0 & $06 / 19 / 94$ & 302 & 47 & 2,100 & 225 & 1,000 & 96 & 2.3 & 0.1 & 579 & 27 & 310 & 15 \\
\hline AR34.5 & $06 / 20 / 94$ & 256 & -- & 4,880 & -- & 1,200 & -- & 3.4 & -- & 1,080 & - & 519 & -- \\
\hline AR31.0 & $06 / 20 / 94$ & 273 & 42 & 1,900 & 203 & 904 & 87 & 2.1 & 0.1 & 523 & 24 & 281 & 14 \\
\hline AR34.5 & $06 / 21 / 94$ & 233 & -- & 4,440 & -- & 1,100 & -- & 3.1 & -- & 989 & - & 473 & -- \\
\hline AR31.0 & $06 / 21 / 94$ & 374 & 58 & 2,600 & 278 & 1,240 & 119 & 2.9 & 0.1 & 717 & 33 & 384 & 19 \\
\hline AR34.5 & $06 / 22 / 94$ & 284 & -- & 5,400 & -- & 1,330 & -- & 3.8 & -- & 1,200 & - & 575 & -- \\
\hline AR31.0 & $06 / 22 / 94$ & 438 & 68 & 3,050 & 326 & 1,450 & 140 & 3.4 & 0.1 & 841 & 39 & 451 & 22 \\
\hline
\end{tabular}


Table 6. Estimated daily dissolved-metal loads and standard errors for sites AR34.5 and AR31.0, April 1994 through March 1995-Continued

[Loads and standard errors are in pounds per day; <, less than; --, no data]

\begin{tabular}{|c|c|c|c|c|c|c|c|c|c|c|c|c|c|}
\hline \multirow[b]{2}{*}{ Site } & \multirow[b]{2}{*}{ Date } & \multicolumn{2}{|c|}{ Aluminum } & \multicolumn{2}{|c|}{ Iron } & \multicolumn{2}{|c|}{ Copper } & \multicolumn{2}{|c|}{ Cadmium } & \multicolumn{2}{|c|}{ Manganese } & \multicolumn{2}{|c|}{ ZInc } \\
\hline & & Load & $\begin{array}{l}\text { Standard } \\
\text { error }\end{array}$ & Load & $\begin{array}{c}\text { Standard } \\
\text { error }\end{array}$ & Load & $\begin{array}{c}\text { Standard } \\
\text { error }\end{array}$ & Load & $\begin{array}{l}\text { Standard } \\
\text { error }\end{array}$ & Load & $\begin{array}{l}\text { Standard } \\
\text { error }\end{array}$ & Load & $\begin{array}{c}\text { Standard } \\
\text { error }\end{array}$ \\
\hline$\overline{\text { AR34.5 }}$ & $06 / 23 / 94$ & 194 & -- & 3,690 & -- & 909 & -- & 2.6 & - & 821 & - & 393 & -- \\
\hline AR31.0 & $06 / 23 / 94$ & 403 & 62 & 2,800 & 300 & 1,330 & 129 & 3.1 & 0.1 & 773 & 36 & 414 & 20 \\
\hline AR34.5 & $06 / 24 / 94$ & 925 & 378 & 6,140 & 671 & 2,040 & 278 & 4.1 & 0.6 & 847 & 100 & 573 & 48 \\
\hline AR31.0 & $06 / 24 / 94$ & 331 & 51 & 2,300 & 246 & 1,100 & 106 & 2.5 & 0.1 & 635 & 29 & 340 & 17 \\
\hline AR34.5 & $06 / 25 / 94$ & 806 & 329 & 5,350 & 585 & 1,780 & 242 & 3.6 & 0.6 & 738 & 87 & 499 & 42 \\
\hline AR31.0 & $06 / 25 / 94$ & 278 & 43 & 1,940 & 207 & 921 & 89 & 2.1 & 0.1 & 534 & 25 & 286 & 14 \\
\hline AR34.5 & $06 / 26 / 94$ & 719 & 294 & 4,770 & 522 & 1,580 & 216 & 3.2 & 0.5 & 658 & 78 & 446 & 68 \\
\hline AR31.0 & $06 / 26 / 94$ & 266 & 41 & 1,850 & 199 & 882 & 85 & 2.0 & 0.1 & 511 & 24 & 274 & 13 \\
\hline AR34.5 & $06 / 27 / 94$ & 630 & 257 & 4,180 & 457 & 1,390 & 190 & 2.8 & 0.4 & 576 & 68 & 390 & 33 \\
\hline AR31.0 & $06 / 27 / 94$ & 266 & 41 & 1,850 & 198 & 882 & 85 & 2.0 & 0.1 & 511 & 24 & 274 & 13 \\
\hline AR34.5 & $06 / 28 / 94$ & 558 & 228 & 3,704 & 405 & 1,230 & 168 & 2.5 & 0.4 & 511 & 60 & 346 & 29 \\
\hline AR31.0 & $06 / 28 / 94$ & 266 & 41 & 1,850 & 198 & 882 & 85 & 2.0 & 0.1 & 511 & 24 & 274 & 13 \\
\hline AR34.5 & $06 / 29 / 94$ & 486 & 198 & 3,230 & 353 & 1,070 & 146 & 2.2 & 0.3 & 445 & 52 & 301 & 26 \\
\hline AR31.0 & $06 / 29 / 94$ & 265 & 41 & 1,850 & 198 & 879 & 85 & 2.0 & 0.1 & 509 & 24 & 273 & 13 \\
\hline AR34.5 & $06 / 30 / 94$ & 436 & 178 & 2,890 & 316 & 960 & 131 & 1.9 & 0.3 & 399 & 47 & 270 & 23 \\
\hline AR31.0 & $06 / 30 / 94$ & 244 & 38 & 1,700 & 182 & 808 & 78 & 1.9 & 0.1 & 468 & 22 & 251 & 12 \\
\hline AR34.5 & $07 / 01 / 94$ & 394 & 161 & 2,610 & 286 & 868 & 119 & 1.8 & 0.3 & 360 & 42 & 244 & 21 \\
\hline AR31.0 & $07 / 01 / 94$ & 228 & 35 & 1,580 & 170 & 754 & 73 & 1.8 & 0.1 & 437 & 20 & 234 & 11 \\
\hline AR34.5 & $07 / 02 / 94$ & 376 & 154 & 2,500 & 273 & 828 & 113 & 1.7 & 0.3 & 344 & 41 & 233 & 20 \\
\hline AR31.0 & $07 / 02 / 94$ & 228 & 35 & 1,580 & 170 & 754 & 73 & 1.8 & 0.1 & 437 & 20 & 234 & 11 \\
\hline AR34.5 & $07 / 03 / 94$ & 337 & 138 & 2,240 & 245 & 743 & 102 & 1.5 & 0.2 & 309 & 36 & 209 & 18 \\
\hline AR31.0 & $07 / 03 / 94$ & 227 & 35 & 1,580 & 169 & 751 & 72 & 1.7 & 0.1 & 435 & 200 & 233 & 11 \\
\hline AR34.5 & $07 / 04 / 94$ & 316 & 129 & 2,100 & 230 & 697 & 95 & 1.4 & 0.2 & 290 & 34 & 196 & 17 \\
\hline AR31.0 & $07 / 04 / 94$ & 211 & 33 & 1,460 & 157 & 697 & 67 & 1.6 & 0.1 & 404 & 19 & 217 & 11 \\
\hline AR34.5 & $07 / 05 / 94$ & 274 & 112 & 1,820 & 199 & 605 & 83 & 1.2 & 0.2 & 251 & 30 & 170 & 14 \\
\hline AR31.0 & $07 / 05 / 94$ & 201 & 31 & 1,400 & 150 & 665 & 64 & 1.5 & 0.1 & 385 & 18 & 507 & 10 \\
\hline AR34.5 & $07 / 06 / 94$ & 251 & 102 & 1,660 & 182 & 552 & 76 & 1.1 & 0.2 & 229 & 27 & 155 & 13 \\
\hline AR31.0 & $07 / 06 / 94$ & 201 & 31 & 1,400 & 150 & 665 & 64 & 1.5 & 0.1 & 385 & 18 & 207 & 10 \\
\hline AR34.5 & $07 / 07 / 94$ & 239 & 97 & 1,580 & 173 & 526 & 72 & 1.1 & 0.2 & 218 & 26 & 148 & 12 \\
\hline AR31.0 & $07 / 07 / 94$ & 201 & 31 & 1,400 & 150 & 665 & 64 & 1.5 & 0.1 & 385 & 18 & 207 & 10 \\
\hline AR34.5 & $07 / 08 / 94$ & 215 & 88 & 1,430 & 156 & 473 & 65 & 1.0 & 0.1 & 197 & 23 & 133 & 11 \\
\hline AR31.0 & $07 / 08 / 94$ & 200 & 31 & 1,390 & 149 & 662 & 64 & 1.5 & 0.1 & 383 & 18 & 206 & 10 \\
\hline AR34.5 & $07 / 09 / 94$ & 209 & 85 & 1,390 & 152 & 460 & 63 & 0.9 & 0.1 & 191 & 22 & 129 & 11 \\
\hline AR31.0 & $07 / 09 / 94$ & 196 & 30 & 1,360 & 146 & 647 & 62 & 1.5 & 0.1 & 375 & 17 & 201 & 10 \\
\hline AR34.5 & $07 / 10 / 94$ & 194 & 79 & 1,290 & 141 & 427 & 58 & 0.9 & 0.1 & 178 & 21 & 120 & 10 \\
\hline AR31.0 & $07 / 10 / 94$ & 177 & 78 & 1,230 & 132 & 587 & 57 & 1.4 & 0.1 & 340 & 16 & 182 & 9 \\
\hline AR34.5 & $07 / 11 / 94$ & 185 & 76 & 1,230 & 134 & 408 & 56 & 0.8 & 0.1 & 169 & 20 & 115 & 10 \\
\hline AR31.0 & $07 / 11 / 94$ & 384 & 42 & 712 & 152 & 706 & 50 & 1.7 & 0.1 & 543 & 7.5 & 236 & 8 \\
\hline AR34.5 & $07 / 12 / 94$ & 176 & 72 & 1,170 & 128 & 388 & 53 & 0.8 & 0.1 & 161 & 19 & 109 & 9.2 \\
\hline AR31.0 & $07 / 12 / 94$ & 354 & 39 & 657 & 141 & 652 & 46 & 1.6 & 0.1 & 502 & 6.9 & 218 & 7.1 \\
\hline AR34.5 & $07 / 13 / 94$ & 170 & 69 & 1,130 & 123 & 375 & 51 & 0.8 & 0.1 & 156 & 18 & 105 & 8.9 \\
\hline AR31.0 & $07 / 13 / 94$ & 354 & 38 & 657 & 141 & 652 & 46 & 1.6 & 0.1 & 502 & 6.9 & 218 & 7.1 \\
\hline
\end{tabular}


Table 6. Estimated daily dissolved-metal loads and standard errors for sites AR34.5 and AR31.0, April 1994 through March 1995-Continued

[Loads and standard errors are in pounds per day; <, less than; --, no data]

\begin{tabular}{|c|c|c|c|c|c|c|c|c|c|c|c|c|c|}
\hline \multirow[b]{2}{*}{ Site } & \multirow[b]{2}{*}{ Date } & \multicolumn{2}{|c|}{ Aluminum } & \multicolumn{2}{|c|}{ Iron } & \multicolumn{2}{|c|}{ Copper } & \multicolumn{2}{|c|}{ Cadmlum } & \multicolumn{2}{|c|}{ Manganese } & \multicolumn{2}{|c|}{ Zlnc } \\
\hline & & Load & $\begin{array}{l}\text { Standard } \\
\text { error }\end{array}$ & Load & $\begin{array}{c}\text { Standard } \\
\text { error }\end{array}$ & Load & $\begin{array}{l}\text { Standard } \\
\text { error }\end{array}$ & Load & $\begin{array}{c}\text { Standard } \\
\text { error }\end{array}$ & Load & $\begin{array}{l}\text { Standard } \\
\text { error }\end{array}$ & Load & $\begin{array}{c}\text { Standard } \\
\text { orror }\end{array}$ \\
\hline$\overline{\text { AR34.5 }}$ & $07 / 14 / 94$ & 155 & 63 & 1,030 & 113 & 342 & 47 & 0.7 & 0.1 & 142 & 17 & 96 & 8.1 \\
\hline AR31.0 & $07 / 14 / 94$ & 352 & 38 & 652 & 140 & 647 & 45 & 1.6 & 0.1 & 498 & 6.8 & 216 & 7.0 \\
\hline AR34.5 & $07 / 15 / 94$ & 152 & 62 & 1,010 & 110 & 335 & 46 & 0.7 & 0.1 & 139 & 16 & 94 & 8.0 \\
\hline AR31.0 & $07 / 15 / 94$ & 344 & 37 & 638 & 137 & 632 & 44 & 1.5 & 0.1 & 487 & 6.7 & 211 & 6.8 \\
\hline AR34.5 & $07 / 16 / 94$ & 146 & 60 & 971 & 106 & 322 & 44 & 0.7 & 0.1 & 134 & 16 & 91 & 7.7 \\
\hline AR31.0 & $07 / 16 / 94$ & 341 & 37 & 633 & 136 & 627 & 44 & 1.5 & 0.1 & 483 & 6.6 & 210 & 6.8 \\
\hline AR34.5 & $07 / 17 / 94$ & 134 & 55 & 891 & 98 & 296 & 40 & 0.6 & 0.1 & 123 & 14 & 83 & 7.0 \\
\hline AR31.0 & $07 / 17 / 94$ & 336 & 36 & 623 & 134 & 618 & 43 & 1.5 & 0.1 & 475 & 6.5 & 206 & 6.7 \\
\hline AR34.5 & $07 / 18 / 94$ & 125 & 51 & 832 & 91 & 276 & 68 & 0.6 & 0.1 & 115 & 14 & 78 & 6.6 \\
\hline AR31.0 & $07 / 18 / 94$ & 322 & 35 & 598 & 128 & 593 & 42 & 1.4 & 0.1 & 456 & 6.3 & 198 & 6.4 \\
\hline AR34.5 & $07 / 19 / 94$ & 125 & 51 & 832 & 91 & 276 & 68 & 0.6 & 0.1 & 115 & 14 & 78 & 6.6 \\
\hline AR31.0 & $07 / 19 / 94$ & 306 & 33 & 568 & 122 & 564 & 40 & 1.4 & 0.1 & 434 & 6.0 & 188 & 6.1 \\
\hline AR34.5 & $07 / 20 / 94$ & 5,230 & -- & 2,660 & -- & 1,870 & - & 2.5 & -- & 1,050 & -- & 473 & - \\
\hline AR31.0 & $07 / 20 / 94$ & 346 & 68 & 642 & 138 & 637 & 45 & 1.5 & 0.1 & 490 & 6.7 & 213 & 6.9 \\
\hline AR34.5 & $07 / 21 / 94$ & 345 & -- & 1,270 & -- & 385 & -- & 0.7 & - & 230 & - & 104 & -- \\
\hline AR31.0 & $07 / 21 / 94$ & 365 & 40 & 677 & 145 & 672 & 47 & 1.6 & 0.1 & 517 & 7.1 & 224 & 7.3 \\
\hline AR34.5 & $07 / 22 / 94$ & 352 & - & 1,300 & -- & 393 & -- & 0.7 & -- & 235 & - & 106 & -- \\
\hline AR31.0 & $07 / 22 / 94$ & 360 & 39 & 667 & 143 & 662 & 46 & 1.6 & 0.1 & 509 & 7.0 & 221 & 7.2 \\
\hline AR34.5 & $07 / 23 / 94$ & 283 & - & 1,040 & -- & 316 & - & 0.6 & - & 1,890 & -- & 85 & -- \\
\hline AR31.0 & $07 / 23 / 94$ & 282 & 31 & 524 & 112 & 520 & 36 & 1.3 & 0.1 & 400 & 5.5 & 174 & 5.6 \\
\hline AR34.5 & $07 / 24 / 94$ & 290 & -- & 1,070 & -- & 324 & -- & 0.6 & -- & 193 & -- & 87 & - \\
\hline AR31.0 & $07 / 24 / 94$ & 234 & 26 & 435 & 93 & 431 & 30 & 1.0 & 0.1 & 332 & 4.6 & 144 & 4.7 \\
\hline AR34.5 & $07 / 25 / 94$ & 386 & -- & 1,430 & -- & 432 & -- & 0.8 & - & 258 & -- & 116 & -- \\
\hline AR31.0 & $07 / 25 / 94$ & 237 & 26 & 440 & 94 & 437 & 31 & 1.1 & 0.1 & 336 & 4.6 & 44 & 4.7 \\
\hline AR34.5 & $07 / 26 / 94$ & 310 & -- & 1,150 & -- & 347 & -- & 0.6 & - & 207 & -- & 93 & - \\
\hline AR31.0 & $07 / 26 / 94$ & 237 & 26 & 440 & 94 & 436 & 31 & 1.1 & 0.1 & 336 & 4.6 & 146 & 4.7 \\
\hline AR34.5 & $07 / 27 / 94$ & 269 & -- & 994 & -- & 301 & -- & 0.5 & -- & 179 & -- & 81 & -- \\
\hline AR31.0 & $07 / 27 / 94$ & 237 & 26 & 440 & 94 & 436 & 31 & 1.1 & 0.1 & 336 & 4.6 & 146 & 4.7 \\
\hline AR34.5 & $07 / 28 / 94$ & 317 & -- & 1,170 & -- & 355 & -- & 0.6 & -- & 212 & -- & 96 & - \\
\hline AR31.0 & $07 / 28 / 94$ & 237 & 26 & 440 & 94 & 436 & 31 & 1.1 & 0.1 & 336 & 4.6 & 146 & 4.7 \\
\hline AR34.5 & $07 / 29 / 94$ & 359 & -- & 1,320 & - & 401 & -- & 0.7 & - & 239 & -- & 108 & -- \\
\hline AR31.0 & $07 / 29 / 94$ & 237 & 26 & 440 & 94 & 436 & 31 & 1.1 & 0.1 & 336 & 4.6 & 146 & 4.7 \\
\hline AR34.5 & $07 / 30 / 94$ & 317 & -- & 1,170 & -- & 355 & -- & 0.6 & -- & 212 & -- & 96 & -- \\
\hline AR31.0 & $07 / 30 / 94$ & 235 & 26 & 435 & 93 & 431 & 30 & 1.0 & 0.1 & 332 & 4.6 & 144 & 4.7 \\
\hline AR34.5 & $07 / 31 / 94$ & 45 & -- & 742 & -- & 206 & -- & 0.6 & - & 289 & - & 99 & -- \\
\hline AR31.0 & $07 / 31 / 94$ & 234 & 26 & 435 & 93 & 431 & 30 & 1.0 & 0.1 & 332 & 4.6 & 144 & 4.7 \\
\hline AR34.5 & $08 / 01 / 94$ & 62 & -- & 1,020 & -- & 283 & -- & 0.8 & - & 396 & -- & 136 & -- \\
\hline AR31.0 & $08 / 01 / 94$ & 264 & 29 & 489 & 105 & 485 & 34 & 1.2 & 0.1 & 374 & 5.1 & 162 & 5.2 \\
\hline AR34.5 & $08 / 02 / 94$ & 67 & - & 1,100 & -. & 306 & - & 0.9 & -- & 428 & -- & 147 & -- \\
\hline AR31.0 & $08 / 02 / 94$ & 280 & 30 & 519 & 111 & 515 & 36 & 1.2 & 0.1 & 396 & 5.4 & 172 & 5.6 \\
\hline AR34.5 & $08 / 03 / 94$ & 246 & - & 1,140 & -- & 364 & -- & 0.7 & -- & 247 & -- & 104 & -- \\
\hline AR31.0 & $08 / 03 / 94$ & 277 & 30 & 514 & 110 & 610 & 36 & 1.2 & 0.1 & 392 & 5.4 & 170 & 5.5 \\
\hline
\end{tabular}


Table 6. Estimated daily dissolved-metal loads and standard errors for sites AR34.5 and AR31.0, April 1994 through March 1995-Continued

[Loads and standard errors are in pounds per day; <, less than; --, no data]

\begin{tabular}{|c|c|c|c|c|c|c|c|c|c|c|c|c|c|}
\hline \multirow[b]{2}{*}{ Site } & \multirow[b]{2}{*}{ Date } & \multicolumn{2}{|c|}{ Aluminum } & \multicolumn{2}{|c|}{ Iron } & \multicolumn{2}{|c|}{ Copper } & \multicolumn{2}{|c|}{ Cadmlum } & \multicolumn{2}{|c|}{ Manganese } & \multicolumn{2}{|c|}{ Zlinc } \\
\hline & & Load & $\begin{array}{c}\text { Standard } \\
\text { error }\end{array}$ & Load & $\begin{array}{l}\text { Standard } \\
\text { error }\end{array}$ & Load & $\begin{array}{l}\text { Standard } \\
\text { error }\end{array}$ & Load & $\begin{array}{l}\text { Standard } \\
\text { error }\end{array}$ & Load & $\begin{array}{l}\text { Standard } \\
\text { error }\end{array}$ & Load & $\begin{array}{l}\text { Standard } \\
\text { error }\end{array}$ \\
\hline$\overline{\mathrm{AR} 34.5}$ & $08 / 04 / 94$ & 199 & -- & 917 & -- & 294 & $\overline{-.}$ & 0.6 & -- & 199 & -- & 84 & $\overline{--}$ \\
\hline AR31.0 & $08 / 04 / 94$ & 277 & 30 & 514 & 110 & 510 & 36 & 1.2 & 0.1 & 392 & 5.4 & 170 & 5.5 \\
\hline AR34.5 & $08 / 05 / 94$ & 190 & - & 873 & -- & 280 & -- & 0.6 & -- & 190 & -- & 80 & -- \\
\hline AR31.0 & 08/05/94 & 213 & 23 & 395 & 85 & 392 & 78 & 0.9 & 0.1 & 302 & 4.1 & 131 & 4.2 \\
\hline AR34.5 & $08 / 06 / 94$ & 204 & - & 939 & -- & 301 & -- & 0.6 & - & 204 & -- & 86 & -- \\
\hline AR31.0 & $08 / 06 / 94$ & 171 & 18 & 316 & 68 & 314 & 22 & 0.8 & 0.1 & 242 & 3.3 & 105 & 3.4 \\
\hline AR34.5 & $08 / 07 / 94$ & 185 & - & 851 & -- & 273 & - & 0.5 & - & 185 & - & 78 & - \\
\hline AR31.0 & 08/07/94 & 168 & 18 & 311 & 67 & 309 & 22 & 0.7 & 0.1 & 238 & 3.3 & 103 & 3.3 \\
\hline AR34.5 & $08 / 08 / 94$ & 161 & -- & 742 & -- & 238 & -- & 0.5 & - & 162 & - & 68 & - \\
\hline AR31.0 & $08 / 08 / 94$ & 157 & 17 & 292 & 62 & 289 & 20 & 0.7 & $<0.1$ & 223 & 3.1 & 97 & 3.1 \\
\hline AR34.5 & $08 / 09 / 94$ & 152 & -- & 698 & -- & 224 & -- & 0.4 & -- & 152 & -- & 64 & -- \\
\hline AR31.0 & $08 / 09 / 94$ & 144 & 16 & 267 & 57 & 265 & 19 & 0.6 & $<0.1$ & 204 & 2.8 & 88 & 2.9 \\
\hline AR34.5 & $08 / 10 / 94$ & 180 & -- & 830 & -- & 266 & - & 0.5 & -- & 180 & -- & 76 & - \\
\hline AR31.0 & $08 / 10 / 94$ & 154 & 17 & 287 & 61 & 284 & 20 & 0.7 & $<0.1$ & 219 & 3.0 & 95 & 3.1 \\
\hline AR34.5 & $08 / 11 / 94$ & 341 & - & 966 & -- & 375 & -- & 0.9 & -- & 275 & -- & 109 & -- \\
\hline AR31.0 & $08 / 11 / 94$ & 162 & 18 & 302 & 65 & 299 & 21 & 0.7 & 0.1 & 230 & 3.2 & 100 & 3.2 \\
\hline AR34.5 & $08 / 12 / 94$ & 275 & -- & 1,270 & -- & 406 & - & 0.8 & - & 275 & -- & 116 & - \\
\hline AR31.0 & $08 / 12 / 94$ & 189 & 25 & 846 & 33 & 304 & 12 & 0.8 & 0.1 & 355 & 11 & 114 & 2.9 \\
\hline AR34.5 & $08 / 13 / 94$ & 213 & -- & 982 & -- & 315 & -- & 0.6 & - & 214 & -- & 90 & -- \\
\hline AR31.0 & $08 / 13 / 94$ & 207 & 27 & 928 & 36 & 333 & 13 & 0.8 & 0.1 & 389 & 12 & 125 & 3.2 \\
\hline AR34.5 & $08 / 14 / 94$ & 298 & -- & 369 & -- & 181 & -- & 0.6 & - & 365 & -- & 87 & -- \\
\hline AR31.0 & $08 / 14 / 94$ & 205 & 27 & 916 & 35 & 329 & 13 & 0.8 & 0.1 & 384 & 12 & 123 & 3.2 \\
\hline AR34.5 & $08 / 15 / 94$ & 426 & -- & 528 & -- & 260 & -- & 0.9 & -- & 524 & -- & 124 & -- \\
\hline AR31.0 & $08 / 15 / 94$ & 205 & 27 & 916 & 35 & 329 & 163 & 0.8 & 0.1 & 384 & 12 & 123 & 3.2 \\
\hline AR34.5 & $08 / 16 / 94$ & 140 & 22 & 1,400 & 45 & 267 & 19 & 0.7 & 0.1 & 333 & 13 & 115 & 3.1 \\
\hline AR31.0 & $08 / 16 / 94$ & 238 & 31 & 1,070 & 41 & 383 & 15 & 1.0 & 0.1 & 447 & 14 & 144 & 3.7 \\
\hline AR34.5 & $08 / 17 / 94$ & 111 & 17 & 1,110 & 36 & 211 & 15 & 0.5 & $<0.1$ & 263 & 10 & 91 & 2.4 \\
\hline AR31.0 & $08 / 17 / 94$ & 262 & 34 & 1,170 & 45 & 420 & 16 & 1.0 & 0.1 & 491 & 15 & 158 & 4.1 \\
\hline AR34.5 & $08 / 18 / 94$ & 90 & 14 & 901 & 29 & 171 & 12 & 0.4 & $<0.1$ & 214 & 8.2 & 74 & 2.0 \\
\hline AR31.0 & $08 / 18 / 94$ & 215 & 28 & 962 & 37 & 346 & 13 & 0.9 & 0.1 & 403 & 12 & 130 & 3.4 \\
\hline AR34.5 & $08 / 19 / 94$ & 88 & 14 & 880 & 28 & 167 & 12 & 0.4 & $<0.1$ & 209 & 8.0 & 72 & 1.9 \\
\hline AR31.0 & $08 / 19 / 94$ & 187 & 25 & 835 & 32 & 300 & 12 & 0.7 & 0.1 & 350 & 11 & 112 & 2.9 \\
\hline AR34.5 & $08 / 20 / 94$ & 90 & 14 & 901 & 29 & 171 & 12 & 0.4 & $<0.1$ & 214 & 8.2 & 74 & 2.0 \\
\hline AR31.0 & $08 / 20 / 94$ & 187 & 25 & 835 & 32 & 300 & 12 & 0.7 & 0.1 & 350 & 11 & 112 & 2.9 \\
\hline AR34.5 & $08 / 21 / 94$ & 88 & 14 & 880 & 28 & 167 & 12 & 0.4 & $<0.1$ & 209 & 8.0 & 72 & 1.9 \\
\hline AR31.0 & $08 / 21 / 94$ & 187 & 25 & 835 & 32 & 300 & 12 & 0.7 & 0.1 & 350 & 11 & 112 & 2.9 \\
\hline AR34.5. & $08 / 22 / 94$ & 86 & 13 & 859 & 28 & 163 & 11 & 0.4 & $<0.1$ & 204 & 7.8 & 70 & 1.9 \\
\hline AR31.0 & $08 / 22 / 94$ & 171 & 22 & 765 & 30 & 275 & 10 & 0.7 & $<0.1$ & 321 & 9.8 & 103 & 2.7 \\
\hline AR34.5 & $08 / 23 / 94$ & 69 & 11 & 692 & 22 & 132 & 9.2 & 0.3 & $<0.1$ & 164 & 6.3 & 57 & 1.5 \\
\hline AR31.0 & $08 / 23 / 94$ & 148 & 20 & 661 & 26 & 237 & 9.1 & 0.6 & $<0.1$ & 277 & 8.5 & 89 & 2.3 \\
\hline AR34.5 & $08 / 24 / 94$ & 63 & 9.7 & 629 & 20 & 120 & 8.3 & 0.3 & $<0.1$ & 149 & 5.7 & 52 & 1.4 \\
\hline AR31.0 & $08 / 24 / 94$ & 137 & 18 & 615 & 24 & 221 & 8.5 & 0.5 & $<0.1$ & 258 & 7.9 & 23 & 2.1 \\
\hline
\end{tabular}


Table 6. Estimated daily dissolved-metal loads and standard errors for sites AR34.5 and AR31.0, April 1994 through March 1995-Continued

[Loads and standard errors are in pounds per day; <, less than; --, no data]

\begin{tabular}{|c|c|c|c|c|c|c|c|c|c|c|c|c|c|}
\hline \multirow[b]{2}{*}{ Site } & \multirow[b]{2}{*}{ Date } & \multicolumn{2}{|c|}{ Aluminum } & \multicolumn{2}{|c|}{ Iron } & \multicolumn{2}{|c|}{ Copper } & \multicolumn{2}{|c|}{ Cadmium } & \multicolumn{2}{|c|}{ Manganese } & \multicolumn{2}{|c|}{ Zlne } \\
\hline & & Load & $\begin{array}{l}\text { Standard } \\
\text { error }\end{array}$ & Load & $\begin{array}{l}\text { Standard } \\
\text { error }\end{array}$ & Load & $\begin{array}{l}\text { Standard } \\
\text { error }\end{array}$ & Load & $\begin{array}{l}\text { Standard } \\
\text { error }\end{array}$ & Load & $\begin{array}{l}\text { Standard } \\
\text { error }\end{array}$ & Load & $\begin{array}{l}\text { Standard } \\
\text { error }\end{array}$ \\
\hline$\overline{\text { AR34.5 }}$ & $08 / 25 / 94$ & 71 & 11 & 713 & 23 & 136 & 9.4 & 0.3 & $<0.1$ & 169 & 6.5 & 58 & 1.6 \\
\hline AR31.0 & $08 / 25 / 94$ & 137 & 18 & 615 & 24 & 221 & 8.5 & 0.5 & $<0.1$ & 258 & 7.9 & 83 & 2.1 \\
\hline AR34.5 & $08 / 26 / 94$ & 75 & 12 & 754 & 24 & 144 & 10 & 0.4 & $<0.1$ & 179 & 6.9 & 62 & 1.6 \\
\hline AR31.0 & $08 / 26 / 94$ & 137 & 18 & 615 & 24 & 221 & 8.5 & 0.5 & $<0.1$ & 258 & 7.9 & 83 & 2.1 \\
\hline AR34.5 & $08 / 27 / 94$ & 61 & 9.4 & 608 & 20 & 116 & 8.0 & 0.3 & $<0.1$ & 144 & 5.5 & 50 & 1.3 \\
\hline AR31.0 & $08 / 27 / 94$ & 137 & 18 & 615 & 24 & 221 & 8.5 & 0.5 & $<0.1$ & 258 & 7.9 & 83 & 2.1 \\
\hline AR34.5 & $08 / 28 / 94$ & 75 & 12 & 754 & 24 & 144 & 10 & 0.4 & $<0.1$ & 179 & 6.9 & 62 & 1.6 \\
\hline AR31.0 & $08 / 28 / 94$ & 140 & 18 & 626 & 24 & 225 & 8.6 & 0.6 & $<0.1$ & 262 & 8.0 & 84 & 2.2 \\
\hline AR34.5 & $08 / 29 / 94$ & 63 & 9.7 & 629 & 20 & 120 & 8.3 & 0.3 & $<0.1$ & 149 & 5.7 & 52 & 1.4 \\
\hline AR31.0 & $08 / 29 / 94$ & 140 & 18 & 626 & 24 & 225 & 8.6 & 0.6 & $<0.1$ & 262 & 8.0 & 84 & 2.2 \\
\hline AR34.5 & $08 / 30 / 94$ & 65 & 10 & 650 & 21 & 124 & 8.6 & 0.3 & $<0.1$ & 154 & 5.9 & 53 & 1.4 \\
\hline AR31.0 & 08/30/94 & 140 & 18 & 626 & 24 & 225 & 8.6 & 0.6 & $<0.1$ & 262 & 8.0 & 84 & 2.2 \\
\hline AR34.5 & $08 / 31 / 94$ & 56 & 8.7 & 566 & 18 & 108 & 7.5 & 0.3 & $<0.1$ & 134 & 5.2 & 46 & 1.2 \\
\hline AR31.0 & $08 / 31 / 94$ & 140 & 18 & 626 & 24 & 225 & 8.6 & 0.6 & $<0.1$ & 262 & 8.0 & 84 & 2.2 \\
\hline AR34.5 & $09 / 01 / 94$ & 86 & 13 & 859 & 28 & 163 & 11 & 0.4 & $<0.1$ & 204 & 7.8 & 70 & 1.9 \\
\hline AR31.0 & $09 / 01 / 94$ & 117 & 15 & 522 & 20 & 187 & 7.2 & 0.5 & $<0.1$ & 219 & 6.7 & 70 & 1.8 \\
\hline AR34.5 & $09 / 02 / 94$ & 235 & -- & 666 & -- & 276 & - & 0.6 & -- & 190 & - & 76 & -- \\
\hline AR31.0 & $09 / 02 / 94$ & 101 & 13 & 452 & 18 & 162 & 6.2 & 0.4 & $<0.1$ & 190 & 5.8 & 61 & 1.6 \\
\hline AR34.5 & $09 / 03 / 94$ & 893 & -- & 2,530 & -- & 1,050 & - & 2.5 & -- & 721 & -- & 287 & -- \\
\hline AR31.0 & $09 / 03 / 94$ & 101 & 13 & 452 & 18 & 162 & 6.2 & 0.4 & $<0.1$ & 190 & 5.8 & 61 & 1.6 \\
\hline AR34.5 & $09 / 04 / 94$ & 676 & -- & 1,910 & - & 793 & - & 1.9 & -- & 545 & - & 217 & -- \\
\hline AR31.0 & $09 / 04 / 94$ & 174 & 23 & 777 & 30 & 279 & 11 & 0.7 & 0.1 & 325 & 10 & 105 & 2.7 \\
\hline AR34.5 & $09 / 05 / 94$ & 476 & -- & 1,350 & -- & 559 & -- & 1.3 & -- & 384 & -. & 153 & -- \\
\hline AR31.0 & $09 / 05 / 94$ & 226 & 30 & 1,010 & 39 & 362 & 14 & 0.9 & 0.1 & 423 & 13 & 136 & 3.5 \\
\hline AR34.5 & $09 / 06 / 94$ & 376 & -- & 1,070 & -- & 441 & - & 1.0 & -- & 304 & -- & 121 & -- \\
\hline AR31.0 & $09 / 06 / 94$ & 226 & 30 & 1,010 & 39 & 362 & 14 & 0.9 & 0.1 & 423 & 13 & 136 & 3.5 \\
\hline AR34.5 & $09 / 07 / 94$ & 34 & -- & 1,050 & -- & 264 & -- & 0.5 & -- & 267 & -- & 100 & -- \\
\hline AR31.0 & $09 / 07 / 94$ & 226 & 30 & 1,010 & 39 & 362 & 14 & 0.9 & 0.1 & 423 & 13 & 136 & 3.5 \\
\hline AR34.5 & $09 / 08 / 94$ & 31 & -- & 976 & -- & 245 & -- & 0.5 & -- & 247 & -- & 92 & -- \\
\hline AR31.0 & $09 / 08 / 94$ & 223 & 29 & 997 & 38 & 358 & 14 & 0.9 & -0.1 & 418 & 13 & 134 & 3.5 \\
\hline AR34.5 & $09 / 09 / 94$ & 27 & -- & 842 & -- & 211 & -- & 0.4 & -- & 213 & -- & 80 & -- \\
\hline AR31.0 & $09 / 09 / 94$ & 150 & 20 & 672 & 26 & 241 & 9.3 & 0.6 & $<0.1$ & 282 & 8.6 & 91 & 2.3 \\
\hline AR34.5 & $09 / 10 / 94$ & 25 & -- & 766 & -- & 192 & -- & 0.4 & - & 194 & -- & 72 & -- \\
\hline AR31.0 & $09 / 10 / 94$ & 106 & 14 & 475 & 18 & 171 & 6.5 & 0.4 & $<0.1$ & 199 & 6.1 & 64 & 1.7 \\
\hline AR34.5 & $09 / 11 / 94$ & 23 & -- & 708 & -- & 178 & -- & 0.4 & -- & 179 & -- & 67 & -- \\
\hline AR31.0 & $09 / 11 / 94$ & 106 & 14 & 475 & 18 & 171 & 6.5 & 0.4 & $<0.1$ & 199 & 6.1 & 64 & 1.7 \\
\hline AR34.5 & $09 / 12 / 94$ & 22 & -- & 689 & -- & 173 & -- & 0.3 & -- & 174 & -- & 65 & -- \\
\hline AR31.0 & $09 / 12 / 94$ & 106 & 14 & 475 & 18 & 171 & 6.5 & 0.4 & $<0.1$ & 199 & 6.1 & 64 & 1.7 \\
\hline AR34.5 & $09 / 13 / 94$ & 31 & -- & 957 & -- & 240 & - & 0.5 & - & 242 & -- & 91 & -- \\
\hline AR31.0 & $09 / 13 / 94$ & 109 & 14 & 487 & 19 & 175 & 6.7 & 0.4 & $<0.1$ & 204 & 6.2 & 66 & 1.7 \\
\hline AR34.5 & $09 / 14 / 94$ & 228 & -- & 1,160 & -- & 350 & -- & 0.7 & -- & 379 & - & 127 & - \\
\hline AR31.0 & $09 / 14 / 94$ & 127 & 17 & 568 & 22 & 204 & 7.8 & 0.5 & $<0.1$ & 238 & 7.3 & 76 & 2.0 \\
\hline
\end{tabular}


Table 6. Estimated daily dissolved-metal loads and standard errors for sites AR34.5 and AR31.0, April 1994 through March 1995-Continued

[Loads and standard errors are in pounds per day; <, less than; --, no data]

\begin{tabular}{|c|c|c|c|c|c|c|c|c|c|c|c|c|c|}
\hline \multirow{2}{*}{ Site } & \multirow[b]{2}{*}{ Date } & \multicolumn{2}{|c|}{ Aluminum } & \multicolumn{2}{|c|}{ Iron } & \multicolumn{2}{|c|}{ Copper } & \multicolumn{2}{|c|}{ Cadmlum } & \multicolumn{2}{|c|}{ Manganese } & \multicolumn{2}{|c|}{ Zinc } \\
\hline & & Load & $\begin{array}{l}\text { Standard } \\
\text { error }\end{array}$ & Load & $\begin{array}{l}\text { Standard } \\
\text { error }\end{array}$ & Load & $\begin{array}{l}\text { Standard } \\
\text { error }\end{array}$ & Load & $\begin{array}{l}\text { Standard } \\
\text { error }\end{array}$ & Load & $\begin{array}{l}\text { Standard } \\
\text { error }\end{array}$ & Load & $\begin{array}{l}\text { Standard } \\
\text { error }\end{array}$ \\
\hline$\overline{\mathrm{AR} 34.5}$ & $09 / 15 / 94$ & 85 & 26 & 1,346 & 150 & 276 & 48 & $\overline{0.9}$ & $\overline{0.1}$ & 329 & 13 & 115 & 7.7 \\
\hline AR31.0 & $09 / 15 / 94$ & 140 & 18 & 626 & 24 & 225 & 8.6 & 0.6 & $<0.1$ & 262 & 8.0 & 84 & 2.2 \\
\hline AR34.5 & $09 / 16 / 94$ & 68 & 20 & 1,070 & 119 & 219 & 38 & 0.7 & 0.1 & 262 & 10 & 91 & 6.1 \\
\hline AR31.0 & $09 / 16 / 94$ & 140 & 18 & 626 & 24 & 225 & 8.6 & 0.6 & $<0.1$ & 262 & 8.0 & 84 & 2.2 \\
\hline AR34.5 & $09 / 17 / 94$ & 60 & 18 & 959 & 107 & 196 & 34 & 0.6 & 0.1 & 234 & 9.2 & 82 & 5.5 \\
\hline AR31.0 & $09 / 17 / 94$ & 140 & 18 & 626 & 24 & 225 & 8.6 & 0.6 & $<0.1$ & 262 & 8.0 & 84 & 2.2 \\
\hline AR34.5 & $09 / 18 / 94$ & 59 & 18 & 941 & 105 & 193 & 33 & 0.6 & 0.1 & 230 & 9.0 & 80 & 5.4 \\
\hline AR31.0 & $09 / 18 / 94$ & 143 & 19 & 638 & 25 & 229 & 8.8 & 0.6 & $<0.1$ & 267 & 8.2 & 86 & 2.2 \\
\hline AR34.5 & $09 / 19 / 94$ & 70 & 21 & 1,110 & 123 & 227 & 39 & 0.7 & 0.1 & 271 & 11 & 94 & 6.3 \\
\hline AR31.0 & $09 / 19 / 94$ & 140 & 18 & 626 & 24 & 225 & 8.6 & 0.6 & $<0.1$ & 262 & 8.0 & 84 & 2.2 \\
\hline AR34.5 & $09 / 20 / 94$ & 63 & 19 & 996 & 111 & 204 & 35 & 0.7 & 0.1 & 244 & 9.5 & 85 & 5.7 \\
\hline AR31.0 & $09 / 20 / 94$ & 140 & 18 & 626 & 24 & 225 & 8.6 & 0.6 & $<0.1$ & 262 & 8.0 & 84 & 2.2 \\
\hline AR34.5 & $09 / 21 / 94$ & 64 & 19 & 1,014 & 113 & 208 & 36 & 0.7 & 0.1 & 248 & 9.7 & 87 & 5.8 \\
\hline AR31.0 & $09 / 21 / 94$ & 124 & 16 & 557 & 22 & 200 & 7.7 & 0.5 & $<0.1$ & 233 & 7.1 & 75 & 1.9 \\
\hline AR34.5 & $09 / 22 / 94$ & 55 & 16 & 867 & 97 & 178 & 31 & 0.6 & $<0.1$ & 212 & 8.3 & 74 & 5.0 \\
\hline AR31.0 & $09 / 22 / 94$ & 117 & 15 & 522 & 20 & 187 & 7.2 & 0.5 & $<0.1$ & 219 & 6.7 & 70 & 1.8 \\
\hline AR34.5 & $09 / 23 / 94$ & 50 & 15 & 793 & 88 & 162 & 28 & 0.5 & $<0.1$ & 194 & 7.6 & 68 & 4.5 \\
\hline AR31.0 & $09 / 23 / 94$ & 117 & 15 & 522 & 20 & 187 & 7.2 & 0.5 & $<0.1$ & 219 & 6.7 & 70 & 1.8 \\
\hline AR34.5 & $09 / 24 / 94$ & 50 & 15 & 793 & 88 & 162 & 28 & 0.5 & $<0.1$ & 194 & 7.6 & 68 & 4.5 \\
\hline AR31.0 & $09 / 24 / 94$ & 117 & 15 & 522 & 20 & 187 & 7.2 & 0.5 & $<0.1$ & 219 & 6.7 & 70 & 1.8 \\
\hline AR34.5 & $09 / 25 / 94$ & 46 & 14 & 738 & 82 & 151 & 26 & 0.5 & $<0.1$ & 180 & 7.0 & 63 & 4.2 \\
\hline AR31.0 & $09 / 25 / 94$ & 117 & 15 & 522 & 20 & 187 & 7.2 & 0.5 & $<0.1$ & 219 & 6.7 & 70 & 1.8 \\
\hline AR34.5 & $09 / 26 / 94$ & 44 & 13 & 701 & 78 & 144 & 25 & 0.5 & $<0.1$ & 171 & 6.7 & 60 & 4.0 \\
\hline AR31.0 & $09 / 26 / 94$ & 117 & 15 & 522 & 20 & 187 & 7.2 & 0.5 & $<0.1$ & 219 & 6.7 & 70 & 1.8 \\
\hline AR34.5 & $09 / 27 / 94$ & 40 & 12 & 627 & 70 & 128 & 22 & 0.4 & $<0.1$ & 153 & 6.0 & 54 & 3.6 \\
\hline AR31.0 & $09 / 27 / 94$ & 117 & 15 & 522 & 20 & 187 & 7.2 & 0.5 & $<0.1$ & 219 & 6.7 & 70 & 1.8 \\
\hline AR34.5 & $09 / 28 / 94$ & 37 & 11 & 590 & 66 & 121 & 21 & 0.4 & $<0.1$ & 144 & 5.6 & 50 & 3.4 \\
\hline AR31.0 & $09 / 28 / 94$ & 117 & 15 & 522 & 20 & 187 & 7.2 & 0.5 & $<0.1$ & 219 & 6.7 & 70 & 1.8 \\
\hline AR34.5 & $09 / 29 / 94$ & 36 & 11 & 572 & 64 & 117 & 20 & 0.4 & $<0.1$ & 140 & 5.5 & 49 & 3.3 \\
\hline AR31.0 & $09 / 29 / 94$ & 117 & 15 & 522 & 20 & 187 & 7.2 & 0.5 & $<0.1$ & 219 & 6.7 & 70 & 1.8 \\
\hline AR34.5 & $09 / 30 / 94$ & 36 & 11 & 572 & 64 & 117 & 20 & 0.4 & $<0.1$ & 140 & 5.5 & 49 & 3.3 \\
\hline AR31.0 & $09 / 30 / 94$ & 117 & 15 & 522 & 20 & 187 & 7.2 & 0.5 & $<0.1$ & 219 & 6.7 & 70 & 1.8 \\
\hline AR34.5 & $10 / 01 / 94$ & 35 & 10 & 553 & 62 & 113 & 20 & 0.4 & $<0.1$ & 135 & 5.3 & 47 & 3.2 \\
\hline AR31.0 & $10 / 01 / 94$ & 132 & 17 & 591 & 23 & 212 & 8.1 & 0.5 & $<0.1$ & 248 & 7.6 & 80 & 2.1 \\
\hline AR34.5 & $10 / 02 / 94$ & 34 & 10 & 535 & 60 & 110 & 19 & 0.4 & $<0.1$ & 131 & 5.1 & 46 & 3.1 \\
\hline AR31.0 & $10 / 02 / 94$ & 140 & 18 & 626 & 24 & 225 & 8.6 & 0.6 & $<0.1$ & 262 & 8.0 & 84 & 2.2 \\
\hline AR34.5 & $10 / 03 / 94$ & 33 & 9.8 & 516 & 58 & 106 & 18 & 0.3 & $<0.1$ & 126 & 4.9 & 44 & 3.0 \\
\hline AR31.0 & $10 / 03 / 94$ & 140 & 18 & 626 & 24 & 225 & 8.6 & 0.6 & $<0.1$ & 262 & 8.0 & 84 & 2.2 \\
\hline AR34.5 & $10 / 04 / 94$ & 31 & 9.5 & 498 & 56 & 102 & 18 & 0.3 & $<0.1$ & 122 & 4.8 & 42 & 2.9 \\
\hline AR31.0 & $10 / 04 / 94$ & 140 & 18 & 626 & 24 & 225 & 8.6 & 0.6 & $<0.1$ & 262 & 8.0 & 84 & 2.2 \\
\hline AR34.5 & $10 / 05 / 94$ & 31 & 9.5 & 498 & 56 & 102 & 18 & 0.3 & $<0.1$ & 122 & 4.8 & 42 & 2.9 \\
\hline AR31.0 & $10 / 05 / 94$ & 143 & 19 & 638 & 25 & 229 & 8.8 & 0.6 & $<0.1$ & 267 & 8.2 & 86 & 2.2 \\
\hline
\end{tabular}


Table 6. Estimated daily dissolved-metal loads and standard errors for sites AR34.5 and AR31.0, April 1994 through March 1995-Continued

[Loads and standard errors are in pounds per day; <, less than; --, no data]

\begin{tabular}{|c|c|c|c|c|c|c|c|c|c|c|c|c|c|}
\hline \multirow[b]{2}{*}{ Slte } & \multirow[b]{2}{*}{ Date } & \multicolumn{2}{|c|}{ Aluminum } & \multicolumn{2}{|c|}{ Iron } & \multicolumn{2}{|c|}{ Copper } & \multicolumn{2}{|c|}{ Cadmlum } & \multicolumn{2}{|c|}{ Manganese } & \multicolumn{2}{|c|}{ ZInc } \\
\hline & & Load & $\begin{array}{l}\text { Standard } \\
\text { error }\end{array}$ & Load & $\begin{array}{l}\text { Standard } \\
\text { error }\end{array}$ & Load & $\begin{array}{l}\text { Standard } \\
\text { error }\end{array}$ & Load & $\begin{array}{l}\text { Standard } \\
\text { error }\end{array}$ & Load & $\begin{array}{l}\text { Standard } \\
\text { error }\end{array}$ & Load & $\begin{array}{l}\text { Standard } \\
\text { error }\end{array}$ \\
\hline$\overline{\text { AR34.5 }}$ & $10 / 06 / 94$ & 31 & 9.5 & 498 & 56 & 102 & 18 & 0.3 & $<0.1$ & 122 & 4.8 & 42 & 2.9 \\
\hline AR31.0 & $10 / 06 / 94$ & 145 & 19 & 649 & 25 & 233 & 8.9 & 0.6 & $<0.1$ & 272 & 8.3 & 88 & 2.3 \\
\hline AR34.5 & $10 / 07 / 94$ & 35 & 10 & 553 & 62 & 113 & 20 & 0.4 & $<0.1$ & 135 & 5.3 & 47 & 3.2 \\
\hline AR31.0 & $10 / 07 / 94$ & 145 & 19 & 649 & 25 & 233 & 8.9 & 0.6 & $<0.1$ & 272 & 8.3 & 88 & 2.3 \\
\hline AR34.5 & $10 / 08 / 94$ & 40 & 12 & 627 & 70 & 128 & 22 & 0.4 & $<0.1$ & 153 & 6.0 & 54 & 3.6 \\
\hline AR31.0 & $10 / 08 / 94$ & 145 & 19 & 649 & 25 & 233 & 8.9 & 0.6 & $<0.1$ & 272 & 8.3 & 88 & 2.3 \\
\hline AR34.5 & $10 / 09 / 94$ & 42 & 13 & 664 & 74 & 136 & 24 & 0.4 & $<0.1$ & 162 & 6.3 & 57 & 3.8 \\
\hline AR31.0 & $10 / 09 / 94$ & 143 & 19 & 638 & 25 & 229 & 8.8 & 0.6 & $<0.1$ & 267 & 8.2 & 86 & 2.2 \\
\hline AR34.5 & $10 / 10 / 94$ & 46 & 14 & 738 & 82 & 151 & 26 & 0.5 & $<0.1$ & 180 & 7.0 & 63 & 4.2 \\
\hline AR31.0 & $10 / 10 / 94$ & 140 & 18 & 626 & 24 & 225 & 8.6 & 0.6 & $<0.1$ & 262 & 8.0 & 84 & 2.2 \\
\hline AR34.5 & $10 / 11 / 94$ & 44 & 13 & 701 & 78 & 144 & 25 & 0.5 & $<0.1$ & 171 & 6.7 & 60 & 4.0 \\
\hline AR31.0 & $10 / 11 / 94$ & 184 & 24 & 823 & 32 & 296 & 11 & 0.7 & 0.1 & 345 & 11 & 111 & 2.9 \\
\hline AR34.5 & $10 / 12 / 94$ & 44 & 13 & 701 & 78 & 144 & 25 & 0.5 & $<0.1$ & 171 & 6.7 & 60 & 4.0 \\
\hline AR31.0 & $10 / 12 / 94$ & 213 & 28 & 951 & 37 & 341 & 13 & 0.8 & 0.1 & 398 & 12 & 128 & 3.3 \\
\hline AR34.5 & $10 / 13 / 94$ & 43 & 13 & 682 & 76 & 140 & 24 & 0.4 & $<0.1$ & 167 & 6.5 & 58 & 3.9 \\
\hline AR31.0 & $10 / 13 / 94$ & 213 & 28 & 951 & 37 & 341 & 13 & 0.8 & 0.1 & 398 & 12 & 128 & 3.3 \\
\hline AR34.5 & $10 / 14 / 94$ & 43 & 13 & 682 & 76 & 140 & 24 & 0.4 & $<0.1$ & 167 & 6.5 & 58 & 3.9 \\
\hline AR31.0 & $10 / 14 / 94$ & 213 & 28 & 951 & 37 & 341 & 13 & 0.8 & 0.1 & 398 & 12 & 128 & 3.3 \\
\hline AR34.5 & $10 / 15 / 94$ & 41 & 12 & 646 & 72 & 132 & 23 & 0.4 & $<0.1$ & 158 & 6.2 & 55 & 3.7 \\
\hline AR31.0 & $10 / 15 / 94$ & 176 & 23 & 788 & 30 & 283 & 11 & 0.7 & 0.1 & 330 & 10 & 106 & 2.7 \\
\hline AR34.5 & $10 / 16 / 94$ & 42 & 13 & 664 & 74 & 136 & 24 & 0.4 & $<0.1$ & 162 & 6.3 & 57 & 3.8 \\
\hline AR31.0 & $10 / 16 / 94$ & 161 & 21 & 719 & 28 & 258 & 9.9 & 0.6 & $<0.1$ & 301 & 9.2 & 97 & 2.5 \\
\hline AR34.5 & $10 / 17 / 94$ & 45 & 14 & 719 & 80 & 147 & 26 & 0.5 & $<0.1$ & 176 & 6.9 & 61 & 4.1 \\
\hline AR31.0 & $10 / 17 / 94$ & 161 & 21 & 719 & 28 & 258 & 9.9 & 0.6 & $<0.1$ & 301 & 9.2 & 97 & 2.5 \\
\hline AR34.5 & $10 / 18 / 94$ & 42 & 13 & 664 & 74 & 136 & 24 & 0.4 & $<0.1$ & 162 & 6.3 & 57 & 3.8 \\
\hline AR31.0 & $10 / 18 / 94$ & 161 & 21 & 719 & 28 & 258 & 9.9 & 0.6 & $<0.1$ & 301 & 9.2 & 97 & 2.5 \\
\hline AR34.5 & $10 / 19 / 94$ & 38 & 12 & 609 & 68 & 125 & 22 & 0.4 & $<0.1$ & 149 & 5.8 & 52 & 3.5 \\
\hline AR31.0 & $10 / 19 / 94$ & 161 & 21 & 719 & 28 & 258 & 9.9 & 0.6 & $<0.1$ & 301 & 9.2 & 97 & 2.5 \\
\hline AR34.5 & $10 / 20 / 94$ & 38 & 12 & 609 & 68 & 125 & 22 & 0.4 & $<0.1$ & 149 & 5.8 & 52 & 3.5 \\
\hline AR31.0 & $10 / 20 / 94$ & 140 & 18 & 626 & 24 & 225 & 8.6 & 0.6 & $<0.1$ & 262 & 8.0 & 84 & 2.2 \\
\hline AR34.5 & $10 / 21 / 94$ & 37 & 11 & 590 & 66 & 121 & 21 & 0.4 & $<0.1$ & 144 & 5.6 & 50 & 3.4 \\
\hline AR31.0 & $10 / 21 / 94$ & 135 & 18 & 603 & 23 & 216 & 8.3 & 0.5 & $<0.1$ & 253 & 7.7 & 81 & 2.1 \\
\hline AR34.5 & $10 / 22 / 94$ & 37 & 11 & 590 & 66 & 121 & 21 & 0.4 & $<0.1$ & 144 & 5.6 & 50 & 3.4 \\
\hline AR31.0 & $10 / 22 / 94$ & 135 & 18 & 603 & 23 & 216 & 8.3 & 0.5 & $<0.1$ & 253 & 7.7 & 81 & 2.1 \\
\hline AR34.5 & $10 / 23 / 94$ & 37 & 11 & 590 & 66 & 121 & 21 & 0.4 & $<0.1$ & 144 & 5.6 & 50 & 3.4 \\
\hline AR31.0 & $10 / 23 / 94$ & 135 & 18 & 603 & 23 & 216 & 8.3 & 0.5 & $<0.1$ & 253 & 7.7 & 81 & 2.1 \\
\hline AR34.5 & $10 / 24 / 94$ & 5.8 & 0.2 & 245 & 21 & 18 & 3.7 & 0.2 & $<0.1$ & 90 & 7.1 & 23 & 1.2 \\
\hline AR31.0 & $10 / 24 / 94$ & 135 & 18 & 603 & 23 & 216 & 8.3 & 0.5 & $<0.1$ & 253 & 7.7 & 81 & 2.1 \\
\hline AR34.5 & $10 / 25 / 94$ & 5.6 & 0.2 & 236 & 21 & 17 & 3.6 & 0.2 & $<0.1$ & 87 & 6.8 & 22 & 1.1 \\
\hline AR31.0 & $10 / 25 / 94$ & 135 & 18 & 603 & 23 & 216 & 8.3 & 0.5 & $<0.1$ & 253 & 7.7 & 81 & 2.1 \\
\hline AR34.5 & $10 / 26 / 94$ & 6.2 & 0.3 & 263 & 23 & 19 & 4.0 & 0.2 & $<0.1$ & 97 & 7.6 & 24 & 1.3 \\
\hline AR31.0 & $10 / 26 / 94$ & 135 & 18 & 603 & 23 & 216 & 8.3 & 0.5 & $<0.1$ & 253 & 7.7 & 81 & 2.1 \\
\hline
\end{tabular}


Table 6. Estimated daily dissolved-metal loads and standard errors for sites AR34.5 and AR31.0, April 1994 through March 1995-Continued

[Loads and standard errors are in pounds per day; <, less than; --, no data]

\begin{tabular}{|c|c|c|c|c|c|c|c|c|c|c|c|c|c|}
\hline \multirow[b]{2}{*}{ Site } & \multirow[b]{2}{*}{ Date } & \multicolumn{2}{|c|}{ Aluminum } & \multicolumn{2}{|c|}{ Iron } & \multicolumn{2}{|c|}{ Copper } & \multicolumn{2}{|c|}{ Cedmlum } & \multicolumn{2}{|c|}{ Manganese } & \multicolumn{2}{|c|}{ ZInc } \\
\hline & & Load & $\begin{array}{c}\text { Standard } \\
\text { error }\end{array}$ & Load & $\begin{array}{l}\text { Standard } \\
\text { error }\end{array}$ & Load & $\begin{array}{l}\text { Standard } \\
\text { error }\end{array}$ & Load & $\begin{array}{l}\text { Standard } \\
\text { error }\end{array}$ & Load & $\begin{array}{c}\text { Standard } \\
\text { error }\end{array}$ & Load & $\begin{array}{l}\text { Standard } \\
\text { error }\end{array}$ \\
\hline$\overline{\mathrm{AR} 34.5}$ & $10 / 27 / 94$ & 4.6 & 0.2 & 193 & 17 & 14 & 2.9 & 0.1 & $<0.1$ & 71 & 5.6 & 18 & 0.9 \\
\hline AR31.0 & $10 / 27 / 94$ & 135 & 18 & 603 & 23 & 216 & 8.3 & 0.5 & $<0.1$ & 253 & 7.7 & 81 & 2.1 \\
\hline AR34.5 & $10 / 28 / 94$ & 5.8 & 0.2 & 245 & 21 & 18 & 3.7 & 0.2 & $<0.1$ & 90 & 7.1 & 23 & 1.2 \\
\hline AR31.0 & $10 / 28 / 94$ & 135 & 18 & 603 & 23 & 216 & 8.3 & 0.5 & $<0.1$ & 253 & 7.7 & 81 & 2.1 \\
\hline AR34.5 & $10 / 29 / 94$ & 6.2 & 0.3 & 263 & 23 & 19 & 4.0 & 0.2 & $<0.1$ & 97 & 7.6 & 24 & 1.3 \\
\hline AR31.0 & $10 / 29 / 94$ & 135 & 18 & 603 & 23 & 216 & 8.3 & 0.5 & $<0.1$ & 253 & 7.7 & 81 & 2.1 \\
\hline AR34.5 & $10 / 30 / 94$ & 4.3 & 0.2 & 184 & 16 & 13 & 2.8 & 0.1 & $<0.1$ & 68 & 5.3 & 17 & 0.9 \\
\hline AR31.0 & $10 / 30 / 94$ & 135 & 18 & 603 & 23 & 216 & 8.3 & 0.5 & $<0.1$ & 253 & 7.7 & 81 & 2.1 \\
\hline AR34.5 & $10 / 31 / 94$ & 7.7 & 0.3 & 324 & 28 & 23 & 4.9 & 0.2 & $<0.1$ & 119 & 9.4 & 30 & 1.5 \\
\hline AR31.0 & $10 / 31 / 94$ & 135 & 18 & 603 & 23 & 216 & 8.3 & 0.5 & $<0.1$ & 253 & 7.7 & 81 & 2.1 \\
\hline AR34.5 & $11 / 01 / 94$ & 6.0 & 0.3 & 254 & 22 & 18 & 3.9 & 0.2 & $<0.1$ & 94 & 7.3 & 24 & 1.2 \\
\hline AR31.0 & $11 / 01 / 94$ & 91 & 12 & 406 & 16 & 146 & 5.6 & 0.4 & $<0.1$ & 170 & 5.2 & 55 & 1.4 \\
\hline AR34.5 & $11 / 02 / 94$ & 5.6 & 0.2 & 236 & 21 & 17 & 3.6 & 0.2 & $<0.1$ & 87 & 6.8 & 22 & 1.1 \\
\hline AR31.0 & $11 / 02 / 94$ & 5.6 & -- & 2.1 & -- & 3.2 & -- & 0.1 & -- & 10 & -- & 22 & -- \\
\hline AR34.5 & $11 / 03 / 94$ & 4.8 & 0.2 & 201 & 18 & 14 & 3.1 & 0.1 & $<0.1$ & 74 & 5.8 & 19 & 1.0 \\
\hline AR31.0 & $11 / 03 / 94$ & 5.8 & -- & 2.2 & -- & 3.3 & -- & $<0.1$ & -- & 11 & - & 23 & -- \\
\hline AR34.5 & $11 / 04 / 94$ & 5.0 & 0.2 & 210 & 18 & 15 & 3.2 & 0.1 & $<0.1$ & 77 & 6.1 & 20 & 1.0 \\
\hline AR31.0 & $11 / 04 / 94$ & 4.1 & -- & 1.5 & -- & 2.3 & -- & $<0.1$ & -- & 7.5 & -- & 16 & -- \\
\hline AR34.5 & $11 / 05 / 94$ & 4.6 & 0.2 & 193 & 17 & 14 & 2.9 & 0.1 & $<0.1$ & 71 & 5.6 & 18 & 0.9 \\
\hline AR31.0 & $11 / 05 / 94$ & 2.4 & -- & 0.9 & -- & 1.4 & -- & $<0.1$ & -- & 4.4 & -- & 9.4 & -- \\
\hline AR34.5 & $11 / 06 / 94$ & 4.1 & 0.2 & 175 & 15 & 12 & 2.7 & 0.1 & $<0.1$ & 64 & 5.1 & 16 & 0.8 \\
\hline AR31.0 & $11 / 06 / 94$ & 2.2 & -- & 0.8 & -- & 1.2 & -- & $<0.1$ & -- & 4.0 & -- & 8.5 & -- \\
\hline AR34.5 & $11 / 07 / 94$ & 4.3 & 0.2 & 184 & 16 & 13 & 2.8 & 0.1 & $<0.1$ & 68 & 5.3 & 17 & 0.9 \\
\hline AR31.0 & $11 / 07 / 94$ & 1.3 & -- & 0.5 & -- & 0.7 & -- & $<0.1$ & -- & 2.3 & -- & 5.0 & -- \\
\hline AR34.5 & $11 / 08 / 94$ & 4.6 & 0.2 & 193 & 17 & 14 & 2.9 & 0.1 & $<0.1$ & 71 & 5.6 & 18 & 0.9 \\
\hline AR31.0 & $11 / 08 / 94$ & 0.6 & -- & 0.2 & -- & 0.4 & -- & $<0.1$ & - & 1.2 & -- & 2.6 & -- \\
\hline AR34.5 & $11 / 09 / 94$ & 4.8 & 0.2 & 201 & 18 & 14 & 3.1 & 0.1 & $<0.1$ & 74 & 5.8 & 19 & 1.0 \\
\hline AR31.0 & $11 / 09 / 94$ & 0.6 & -- & 0.2 & - & 0.4 & - & $<0.1$ & - & 1.1 & -- & 2.5 & -- \\
\hline AR34.5 & $11 / 10 / 94$ & 5.0 & 0.2 & 210 & 18 & 15 & 3.2 & 0.1 & $<0.1$ & 77 & 6.1 & 20 & 1.0 \\
\hline AR31.0 & $11 / 10 / 94$ & 0.6 & -- & 0.2 & -- & 0.4 & -- & $<0.1$ & - & 1.2 & -- & 2.6 & -- \\
\hline AR34.5 & $11 / 11 / 94$ & 5.4 & 0.2 & 228 & 20 & 16 & 3.5 & 0.2 & $<0.1$ & 84 & 6.6 & 21 & 1.1 \\
\hline AR31.0 & $11 / 11 / 94$ & 0.7 & -- & 0.3 & -- & 0.4 & -- & $<0.1$ & - & 1.2 & -- & 2.6 & -- \\
\hline AR34.5 & $11 / 12 / 94$ & 5.6 & 0.2 & 236 & 21 & 17 & 3.6 & 0.2 & $<0.1$ & 87 & 6.8 & 22 & 1.1 \\
\hline AR31.0 & $11 / 12 / 94$ & 0.7 & -- & 0.3 & -- & 0.4 & -- & $<0.1$ & -- & 1.3 & -- & 2.7 & -- \\
\hline AR34.5 & $11 / 13 / 94$ & 5.0 & 0.2 & 210 & 18 & 15 & 3.2 & 0.1 & $<0.1$ & 77 & 6.1 & 20 & 1.0 \\
\hline AR31.0 & $11 / 13 / 94$ & 0.7 & -- & 0.3 & -- & 0.4 & -- & $<0.1$ & - & 1.2 & -- & 2.6 & - \\
\hline AR34.5 & $11 / 14 / 94$ & 4.8 & 0.2 & 201 & 18 & 14 & 3.1 & 0.1 & $<0.1$ & 74 & 5.8 & 19 & 1.0 \\
\hline AR31.0 & $11 / 14 / 94$ & 0.7 & -- & 0.3 & -- & 0.4 & -- & $<0.1$ & -- & 1.2 & -- & 2.6 & -- \\
\hline AR34.5 & $11 / 15 / 94$ & 4.3 & 0.2 & 184 & 16 & 13 & 2.8 & 0.1 & $<0.1$ & 68 & 5.3 & 17 & 0.9 \\
\hline AR31.0 & $11 / 15 / 94$ & 0.7 & - & 0.3 & -- & 0.4 & -- & $<0.1$ & - & 1.3 & -- & 2.7 & -- \\
\hline AR34.5 & $11 / 16 / 94$ & 3.9 & 0.2 & 166 & 14 & 12 & 2.5 & 0.1 & $<0.1$ & 61 & 4.8 & 15 & 0.8 \\
\hline AR31.0 & $11 / 16 / 94$ & 0.7 & -- & 0.3 & -- & 0.4 & -- & $<0.1$ & -- & 1.3 & -- & 2.8 & -- \\
\hline
\end{tabular}


Table 6. Estimated daily dissolved-metal loads and standard errors for sites AR34.5 and AR31.0, April 1994 through March 1995-Continued

[Loads and standard errors are in pounds per day; <, less than; --, no data]

\begin{tabular}{|c|c|c|c|c|c|c|c|c|c|c|c|c|c|}
\hline \multirow[b]{2}{*}{ Site } & \multirow[b]{2}{*}{ Date } & \multicolumn{2}{|c|}{ Aluminum } & \multicolumn{2}{|c|}{ Iron } & \multicolumn{2}{|c|}{ Copper } & \multicolumn{2}{|c|}{ Cadmlum } & \multicolumn{2}{|c|}{ Manganese } & \multicolumn{2}{|c|}{ Zinc } \\
\hline & & Load & $\begin{array}{l}\text { Standard } \\
\text { error }\end{array}$ & Load & $\begin{array}{c}\text { Standard } \\
\text { error }\end{array}$ & Load & $\begin{array}{l}\text { Standard } \\
\text { error }\end{array}$ & Load & $\begin{array}{l}\text { Standard } \\
\text { error }\end{array}$ & Load & $\begin{array}{c}\text { Standard } \\
\text { error }\end{array}$ & Load & $\begin{array}{l}\text { Standard } \\
\text { error }\end{array}$ \\
\hline$\overline{\text { AR34.5 }}$ & $11 / 17 / 94$ & 3.9 & 0.2 & 166 & 14 & 12 & 2.5 & 0.1 & $<0.1$ & 61 & 4.8 & 15 & 0.8 \\
\hline AR31.0 & $11 / 17 / 94$ & 0.7 & - & 0.3 & -- & 0.4 & - & $<0.1$ & - & 1.3 & -- & 2.8 & -- \\
\hline AR34.5 & $11 / 18 / 94$ & 3.7 & 0.2 & 158 & 14 & 11 & 2.4 & 0.1 & $<0.1$ & 58 & 4.6 & 15 & 0.8 \\
\hline AR31.0 & $11 / 18 / 94$ & 0.7 & -- & 0.3 & -- & 0.4 & -- & $<0.1$ & -- & 1.3 & - & 2.8 & -- \\
\hline AR34.5 & $11 / 19 / 94$ & 3.9 & 0.2 & 166 & 14 & 12 & 2.5 & 0.1 & $<0.1$ & 61 & 4.8 & 15 & 0.8 \\
\hline AR31.0 & $11 / 19 / 94$ & 0.7 & -- & 0.3 & -- & 0.4 & -- & $<0.1$ & -- & 1.3 & -- & 2.8 & -- \\
\hline AR34.5 & $11 / 20 / 94$ & 3.7 & 0.2 & 158 & 14 & 11 & 2.4 & 0.1 & $<0.1$ & 58 & 4.6 & 15 & 0.8 \\
\hline AR31.0 & $11 / 20 / 94$ & 0.7 & -- & 0.3 & -- & 0.4 & -- & $<0.1$ & -- & 1.3 & - & 2.9 & -- \\
\hline AR34.5 & $11 / 21 / 94$ & 3.9 & 0.2 & 166 & 14 & 12 & 2.5 & 0.1 & $<0.1$ & 61 & 4.8 & 15 & 0.8 \\
\hline AR31.0 & $11 / 21 / 94$ & 0.7 & -- & 0.3 & -- & 0.4 & -- & $<0.1$ & - & 1.3 & - & 2.9 & - \\
\hline AR34.5 & $11 / 22 / 94$ & 4.3 & 0.2 & 184 & 16 & 13 & 2.8 & 0.1 & $<0.1$ & 68 & 5.3 & 17 & 0.9 \\
\hline AR31.0 & $11 / 22 / 94$ & 0.7 & - & 0.3 & -- & 0.4 & -- & $<0.1$ & -- & 1.3 & -- & 2.8 & -- \\
\hline AR34.5 & $11 / 23 / 94$ & 5.0 & 0.2 & 210 & 18 & 15 & 3.2 & 0.1 & $<0.1$ & 77 & 6.1 & 20 & 1.0 \\
\hline AR31.0 & $11 / 23 / 94$ & 0.8 & -- & 0.3 & -- & 0.4 & -- & $<0.1$ & -- & 1.4 & -- & 3.0 & - \\
\hline AR34.5 & $11 / 24 / 94$ & 4.1 & 0.2 & 175 & 15 & 12 & 2.7 & 0.1 & $<0.1$ & 64 & 5.1 & 16 & 0.8 \\
\hline AR31.0 & $11 / 24 / 94$ & 0.8 & -. & 0.3 & -- & 0.4 & -- & $<0.1$ & - & 1.4 & -- & 3.0 & - \\
\hline AR34.5 & $11 / 25 / 94$ & 3.7 & 0.2 & 158 & 14 & 11 & 2.4 & 0.1 & $<0.1$ & 58 & 4.6 & 15 & 0.8 \\
\hline AR31.0 & $11 / 25 / 94$ & 0.8 & -- & 0.3 & -- & 0.4 & -- & $<0.1$ & - & 1.4 & -- & 3.0 & - \\
\hline AR34.5 & $11 / 26 / 94$ & 3.3 & 0.1 & 140 & 12 & 10 & 2.1 & 0.1 & $<0.1$ & 52 & 4.0 & 13 & 0.7 \\
\hline AR31.0 & $11 / 26 / 94$ & 0.8 & -- & 0.3 & -- & 0.4 & - & $<0.1$ & -- & 1.4 & -- & 3.0 & - \\
\hline AR34.5 & $11 / 27 / 94$ & 3.7 & 0.2 & 158 & 14 & 11 & 2.4 & 0.1 & $<0.1$ & 58 & 4.6 & 15 & 0.8 \\
\hline AR31.0 & $11 / 27 / 94$ & 0.8 & -- & 0.3 & - & 0.4 & -- & $<0.1$ & -- & 1.4 & -- & 3.0 & - \\
\hline AR34.5 & $11 / 28 / 94$ & 3.9 & 0.2 & 166 & 14 & 12 & 2.5 & 0.1 & $<0.1$ & 61 & 4.8 & 15 & 0.8 \\
\hline AR31.0 & $11 / 28 / 94$ & 0.8 & -- & 0.3 & - & 0.4 & -- & $<0.1$ & - & 1.4 & -- & 3.0 & -- \\
\hline AR34.5 & $11 / 29 / 94$ & 4.1 & 0.2 & 175 & 15 & 12 & 2.7 & 0.1 & $<0.1$ & 64 & 5.1 & 16 & 0.8 \\
\hline AR31.0 & $11 / 29 / 94$ & 0.8 & -- & 0.3 & -- & 0.4 & -- & $<0.1$ & -- & 1.4 & -- & 3.0 & -- \\
\hline AR34.5 & $11 / 30 / 94$ & 4.3 & 0.2 & 184 & 16 & 13 & 2.8 & 0.1 & $<0.1$ & 68 & 5.3 & 17 & 0.9 \\
\hline AR31.0 & $11 / 30 / 94$ & 0.7 & - & 0.3 & -- & 0.4 & -- & $<0.1$ & -- & 1.2 & -- & 2.6 & -- \\
\hline AR34.5 & $12 / 01 / 94$ & 4.3 & 0.2 & 184 & 16 & 13 & 2.8 & 0.1 & $<0.1$ & 68 & 5.3 & 17 & 0.9 \\
\hline AR31.0 & $12 / 01 / 94$ & 0.6 & -- & 0.2 & -- & 0.4 & - & $<0.1$ & -- & 1.1 & -- & 2.5 & -. \\
\hline AR34.5 & $12 / 02 / 94$ & 4.1 & 0.2 & 175 & 15 & 12 & 2.7 & 0.1 & $<0.1$ & 64 & 5.1 & 16 & 0.8 \\
\hline AR31.0 & $12 / 02 / 94$ & 0.6 & -- & 0.2 & -- & 0.4 & -- & $<0.1$ & -- & 1.1 & - & 2.5 & -- \\
\hline AR34.5 & $12 / 03 / 94$ & 3.9 & 0.2 & 166 & 14 & 12 & 2.5 & 0.1 & $<0.1$ & 61 & 4.8 & 15 & 0.8 \\
\hline AR31.0 & $12 / 03 / 94$ & 0.6 & -- & 0.2 & -- & 0.4 & -- & $<0.1$ & - & 1.1 & -- & 2.5 & -- \\
\hline AR34.5 & $12 / 04 / 94$ & 3.7 & 0.2 & 158 & 14 & 11 & 2.4 & 0.1 & $<0.1$ & 58 & 4.6 & 15 & 0.8 \\
\hline AR31.0 & $12 / 04 / 94$ & 0.6 & -- & 0.2 & -- & 0.4 & -- & $<0.1$ & -- & 1.1 & -- & 2.5 & -- \\
\hline AR34.5 & $12 / 05 / 94$ & 3.9 & 0.2 & 166 & 14 & 12 & 2.5 & 0.1 & $<0.1$ & 61 & 4.8 & 15 & 0.8 \\
\hline AR31.0 & $12 / 05 / 94$ & 0.6 & -- & 0.2 & -- & 0.4 & -- & $<0.1$ & -- & 1.1 & -- & 2.5 & -- \\
\hline AR34.5 & $12 / 06 / 94$ & 3.7 & 0.2 & 158 & 14 & 11 & 2.4 & 0.1 & $<0.1$ & 58 & 4.6 & 15 & 0.8 \\
\hline AR31.0 & $12 / 06 / 94$ & 0.6 & -- & 0.2 & -- & 0.4 & -- & $<0.1$ & -- & 1.2 & -- & 2.6 & -- \\
\hline AR34.5 & $12 / 07 / 94$ & 3.7 & 0.2 & 158 & 14 & 11 & 2.4 & 0.1 & $<0.1$ & 58 & 4.6 & 15 & 0.8 \\
\hline AR31.0 & $12 / 07 / 94$ & 0.7 & -- & 0.3 & -- & 0.4 & -- & $<0.1$ & -- & 1.2 & -- & 2.6 & -- \\
\hline
\end{tabular}


Table 6. Estimated daily dissolved-metal loads and standard errors for sites AR34.5 and AR31.0, April 1994 through March 1995-Continued

[Loads and standard errors are in pounds per day; <, less than; --, no data]

\begin{tabular}{|c|c|c|c|c|c|c|c|c|c|c|c|c|c|}
\hline \multirow[b]{2}{*}{ Site } & \multirow[b]{2}{*}{ Date } & \multicolumn{2}{|c|}{ Aluminum } & \multicolumn{2}{|c|}{ Iron } & \multicolumn{2}{|c|}{ Copper } & \multicolumn{2}{|c|}{ Cadmium } & \multicolumn{2}{|c|}{ Manganese } & \multicolumn{2}{|c|}{ Zine } \\
\hline & & Load & $\begin{array}{l}\text { Standard } \\
\text { error }\end{array}$ & Load & $\begin{array}{l}\text { Standard } \\
\text { error }\end{array}$ & Load & $\begin{array}{l}\text { Standard } \\
\text { error }\end{array}$ & Load & $\begin{array}{l}\text { Standard } \\
\text { error }\end{array}$ & Load & $\begin{array}{l}\text { Standard } \\
\text { error }\end{array}$ & Load & $\begin{array}{l}\text { Standard } \\
\text { error }\end{array}$ \\
\hline$\overline{\text { AR34.5 }}$ & $12 / 08 / 94$ & 3.7 & 0.2 & 158 & 14 & 11 & 2.4 & 0.1 & $<0.1$ & 58 & 4.6 & 15 & 0.8 \\
\hline AR31.0 & $12 / 08 / 94$ & 0.7 & -- & 0.3 & -- & 0.4 & -- & $<0.1$ & -- & 1.2 & -- & 2.6 & -- \\
\hline AR34.5 & $12 / 09 / 94$ & 3.9 & 0.2 & 166 & 14 & 12 & 2.5 & 0.1 & $<0.1$ & 61 & 4.8 & 15 & 0.8 \\
\hline AR31.0 & $12 / 09 / 94$ & 0.7 & -- & 0.3 & -- & 0.4 & - & $<0.1$ & -- & 1.2 & -- & 2.6 & -- \\
\hline AR34.5 & $12 / 10 / 94$ & 4.1 & 0.2 & 175 & 15 & 12 & 2.7 & 0.1 & $<0.1$ & 64 & 5.1 & 16 & 0.8 \\
\hline AR31.0 & $12 / 10 / 94$ & 0.7 & -- & 0.3 & -- & 0.4 & - & $<0.1$ & - & 1.2 & -- & 2.6 & -- \\
\hline AR34.5 & $12 / 11 / 94$ & 3.9 & 0.2 & 166 & 14 & 12 & 2.5 & 0.1 & $<0.1$ & 61 & 4.8 & 15 & 0.8 \\
\hline AR31.0 & $12 / 11 / 94$ & 0.7 & -- & 0.3 & -- & 0.4 & -- & $<0.1$ & - & 1.2 & -- & 2.6 & -- \\
\hline AR34.5 & $12 / 12 / 94$ & 4.1 & 0.2 & 175 & 15 & 12 & 2.7 & 0.1 & $<0.1$ & 64 & 5.1 & 16 & 0.8 \\
\hline AR31.0 & $12 / 12 / 94$ & 0.7 & -- & 0.3 & -- & 0.4 & -- & $<0.1$ & -- & 1.2 & -- & 2.6 & -- \\
\hline AR34.5 & $12 / 13 / 94$ & 3.7 & 0.2 & 158 & 14 & 11 & 2.4 & 0.1 & $<0.1$ & 58 & 4.6 & 15 & 0.8 \\
\hline AR31.0 & $12 / 13 / 94$ & 0.7 & - & 0.3 & - & 0.4 & - & $<0.1$ & $\cdots$ & 1.2 & - & 2.6 & - \\
\hline AR34.5 & $12 / 14 / 94$ & 3.5 & 0.1 & 149 & 13 & 11 & 2.3 & 0.1 & $<0.1$ & 55 & 4.3 & 14 & 0.7 \\
\hline AR31.0 & $12 / 14 / 94$ & 0.7 & -- & 0.3 & - & 0.4 & - & $<0.1$ & - & 1.2 & -- & 2.6 & -. \\
\hline AR34.5 & $12 / 15 / 94$ & 3.7 & 0.2 & 158 & 14 & 11 & 2.4 & 0.1 & $<0.1$ & 58 & 4.6 & 15 & 0.8 \\
\hline AR31.0 & $12 / 15 / 94$ & 0.7 & -- & 0.3 & - & 0.4 & -- & $<0.1$ & - & 1.2 & - & 2.6 & - \\
\hline AR34.5 & $12 / 16 / 94$ & 3.3 & 0.1 & 140 & 12 & 10 & 2.1 & 0.1 & $<0.1$ & 52 & 4.0 & 13 & 0.7 \\
\hline AR31.0 & $12 / 16 / 94$ & 0.7 & - & 0.3 & - & 0.4 & -- & $<0.1$ & - & 1.2 & -- & 2.6 & - \\
\hline AR34.5 & $12 / 17 / 94$ & 3.5 & 0.1 & 149 & 13 & 11 & 2.3 & 0.1 & $<0.1$ & 55 & 4.3 & 14 & 0.7 \\
\hline AR31.0 & $12 / 17 / 94$ & 0.7 & -- & 0.3 & - & 0.4 & -- & $<0.1$ & - & 1.2 & - & 2.6 & - \\
\hline AR34.5 & $12 / 18 / 94$ & 3.5 & 0.1 & 149 & 13 & 11 & 2.3 & 0.1 & $<0.1$ & 55 & 4.3 & 14 & 0.7 \\
\hline AR31.0 & $12 / 18 / 94$ & 0.7 & -- & 0.3 & -- & 0.4 & -. & $<0.1$ & -- & 1.2 & - & 2.6 & - \\
\hline AR34.5 & $12 / 19 / 94$ & 3.3 & 0.1 & 140 & 12 & 10 & 2.1 & 0.1 & $<0.1$ & 52 & 4.0 & 13 & 0.7 \\
\hline AR31.0 & $12 / 19 / 94$ & 0.7 & -- & 0.3 & -- & 0.4 & -- & $<0.1$ & - & 1.2 & -- & 2.6 & - \\
\hline AR34.5 & $12 / 20 / 94$ & 3.5 & 0.1 & 149 & 13 & 11 & 2.3 & 0.1 & $<0.1$ & 55 & 4.3 & 14 & 0.7 \\
\hline AR31.0 & $12 / 20 / 94$ & 0.7 & -- & 0.3 & -- & 0.4 & -- & $<0.1$ & - & 1.2 & -- & 2.6 & - \\
\hline AR34.5 & $12 / 21 / 94$ & 3.3 & 0.1 & 140 & 12 & 10 & 2.1 & 0.1 & $<0.1$ & 52 & 4.0 & 13 & 0.7 \\
\hline AR31.0 & $12 / 21 / 94$ & 0.7 & -- & 0.3 & -- & 0.4 & -- & $<0.1$ & - & 1.2 & -- & 2.6 & - \\
\hline AR34.5 & $12 / 22 / 94$ & 3.3 & 0.1 & 140 & 12 & 10 & 2.1 & 0.1 & $<0.1$ & 52 & 4.0 & 13 & 0.7 \\
\hline AR31.0 & $12 / 22 / 94$ & 0.7 & -- & 0.3 & -- & 0.4 & -- & $<0.1$ & - & 1.2 & -- & 2.6 & -- \\
\hline AR34.5 & $12 / 23 / 94$ & 3.1 & 0.1 & 131 & 12 & 9.4 & 2.0 & 0.1 & $<0.1$ & 48 & 3.8 & 12 & 0.6 \\
\hline AR31.0 & $12 / 23 / 94$ & 0.7 & - & 0.3 & -- & 0.4 & -- & $<0.1$ & - & 1.2 & -- & 2.6 & -- \\
\hline AR34.5 & $12 / 24 / 94$ & 3.5 & 0.1 & 149 & 13 & 11 & 2.3 & 0.1 & $<0.1$ & 55 & 4.3 & 14 & 0.7 \\
\hline AR31.0 & $12 / 24 / 94$ & 0.7 & -- & 0.3 & -- & 0.4 & -- & $<0.1$ & - & 1.2 & -- & 2.6 & - \\
\hline AR34.5 & $12 / 25 / 94$ & 3.3 & 0.1 & 140 & 12 & 10 & 2.1 & 0.1 & $<0.1$ & 52 & 4.0 & 13 & 0.7 \\
\hline AR31.0 & $12 / 25 / 94$ & 0.7 & -- & 0.3 & -- & 0.4 & - & $<0.1$ & - & 1.2 & - & 2.6 & -- \\
\hline AR34.5 & $12 / 26 / 94$ & 3.3 & 0.1 & 140 & 12 & 10 & 2.1 & 0.1 & $<0.1$ & 52 & 4.0 & 13 & 0.7 \\
\hline AR31.0 & $12 / 26 / 94$ & 0.7 & -- & 0.3 & - & 0.4 & -- & $<0.1$ & - & 1.2 & -- & 2.6 & -- \\
\hline AR34.5 & $12 / 27 / 94$ & 3.5 & 0.1 & 149 & 13 & 11 & 2.3 & 0.1 & $<0.1$ & 55 & 4.3 & 14 & 0.7 \\
\hline AR31.0 & $12 / 27 / 94$ & 0.7 & -- & 0.3 & -- & 0.4 & -- & $<0.1$ & - & 1.2 & - & 2.6 & -- \\
\hline AR34.5 & $12 / 28 / 94$ & 3.3 & 0.1 & 140 & 12 & 10 & 2.1 & 0.1 & $<0.1$ & 52 & 4.0 & 13 & 0.7 \\
\hline AR31.0 & $12 / 28 / 94$ & 0.8 & -- & 0.3 & -- & 0.5 & - & $<0.1$ & - & 1.5 & - & 3.2 & -- \\
\hline
\end{tabular}


Table 6. Estimated daily dissolved-metal loads and standard errors for sites AR34.5 and AR31.0, April 1994 through March 1995-Continued

[Loads and standard errors are in pounds per day; <, less than; --, no data]

\begin{tabular}{|c|c|c|c|c|c|c|c|c|c|c|c|c|c|}
\hline \multirow[b]{2}{*}{ Site } & \multirow[b]{2}{*}{ Date } & \multicolumn{2}{|c|}{ Aluminum } & \multicolumn{2}{|c|}{ Iron } & \multicolumn{2}{|c|}{ Copper } & \multicolumn{2}{|c|}{ Cadmlum } & \multicolumn{2}{|c|}{ Manganese } & \multicolumn{2}{|c|}{ ZInc } \\
\hline & & Load & $\begin{array}{c}\text { Standard } \\
\text { error }\end{array}$ & Load & $\begin{array}{c}\text { Standard } \\
\text { error }\end{array}$ & Load & $\begin{array}{c}\text { Standard } \\
\text { error }\end{array}$ & Load & $\begin{array}{l}\text { Standard } \\
\text { error }\end{array}$ & Load & $\begin{array}{l}\text { Standard } \\
\text { error }\end{array}$ & Load & $\begin{array}{l}\text { Standard } \\
\text { error }\end{array}$ \\
\hline$\overline{\text { AR34.5 }}$ & $12 / 29 / 94$ & 3.5 & 0.1 & 149 & 13 & 11 & 2.3 & 0.1 & $<0.1$ & 55 & 4.3 & 14 & 0.7 \\
\hline AR31.0 & $12 / 29 / 94$ & 0.9 & -- & 0.3 & -- & 0.5 & -- & $<0.1$ & -- & 1.6 & - & 3.5 & -- \\
\hline AR34.5 & $12 / 30 / 94$ & 3.1 & 0.1 & 131 & 12 & 9.4 & 2.0 & 0.1 & $<0.1$ & 48 & 3.8 & 12 & 0.6 \\
\hline AR31.0 & $12 / 30 / 94$ & 0.9 & -- & 0.3 & -- & 0.5 & -- & $<0.1$ & -- & 1.6 & -- & 3.5 & - \\
\hline AR34.5 & $12 / 31 / 94$ & 3.1 & 0.1 & 131 & 12 & 9.4 & 2.0 & 0.1 & $<0.1$ & 48 & 3.8 & 12 & 0.6 \\
\hline AR31.0 & $12 / 31 / 94$ & 0.9 & -- & 0.3 & -- & 0.5 & -- & $<0.1$ & - & 1.6 & -- & 3.5 & -- \\
\hline AR34.5 & $01 / 01 / 95$ & 2.7 & 0.1 & 114 & 9.9 & 8.2 & 1.7 & 0.1 & $<0.1$ & 42 & 3.3 & 11 & 0.5 \\
\hline AR31.0 & $01 / 01 / 95$ & 0.9 & -- & 0.3 & -- & 0.5 & -- & $<0.1$ & - & 1.6 & -- & 3.5 & -- \\
\hline AR34.5 & $01 / 02 / 95$ & 2.7 & 0.1 & 114 & 9.9 & 8.2 & 1.7 & 0.1 & $<0.1$ & 42 & 3.3 & 11 & 0.5 \\
\hline AR31.0 & $01 / 02 / 95$ & 0.9 & -- & 0.3 & -. & 0.5 & -- & $<0.1$ & - & 1.6 & -- & 3.5 & -- \\
\hline AR34.5 & $01 / 03 / 95$ & 2.7 & 0.1 & 114 & 9.9 & 8.2 & 1.7 & 0.1 & $<0.1$ & 42 & 3.3 & 11 & 0.5 \\
\hline AR31.0 & $01 / 03 / 95$ & 0.9 & -- & 0.3 & -- & 0.5 & -- & $<0.1$ & -- & 1.6 & -- & 3.5 & -- \\
\hline AR34.5 & $01 / 04 / 95$ & 2.9 & 0.1 & 123 & 11 & 8.8 & 1.9 & 0.1 & $<0.1$ & 45 & 3.5 & 11 & 0.6 \\
\hline AR31.0 & $01 / 04 / 95$ & 0.9 & -- & 0.3 & -- & 0.5 & - & $<0.1$ & - & 1.7 & -- & 3.6 & -- \\
\hline AR34.5 & $01 / 05 / 95$ & 2.9 & 0.1 & 123 & 11 & 8.8 & 1.9 & 0.1 & $<0.1$ & 45 & 3.5 & 11 & 0.6 \\
\hline AR31.0 & $01 / 05 / 95$ & 0.9 & -- & 0.3 & -- & 0.5 & -- & $<0.1$ & -- & 1.7 & -- & 3.7 & -- \\
\hline AR34.5 & $01 / 06 / 95$ & 2.9 & 0.1 & 123 & 11 & 8.8 & 1.9 & 0.1 & $<0.1$ & 45 & 3.5 & 11 & 0.6 \\
\hline AR31.0 & $01 / 06 / 95$ & 0.9 & -- & 0.3 & -. & 0.5 & - & $<0.1$ & - & 1.7 & -- & 3.7 & -- \\
\hline AR34.5 & $01 / 07 / 95$ & 2.9 & 0.1 & 123 & 11 & 8.8 & 1.9 & 0.1 & $<0.1$ & 45 & 3.5 & 11 & 0.6 \\
\hline AR31.0 & $01 / 07 / 95$ & 0.8 & 0.1 & 0.3 & 0.1 & 0.1 & $<0.1$ & $<0.1$ & $<0.1$ & 0.6 & 0.1 & 0.1 & $<0.1$ \\
\hline AR34.5 & $01 / 08 / 95$ & 2.9 & 0.1 & 123 & 11 & 8.8 & 1.9 & 0.1 & $<0.1$ & 45 & 3.5 & 11 & 0.6 \\
\hline AR31.0 & $01 / 08 / 95$ & 0.8 & 0.1 & 0.3 & 0.1 & 0.1 & $<0.1$ & $<0.1$ & $<0.1$ & 0.6 & 0.1 & 0.1 & $<0.1$ \\
\hline AR34.5 & $01 / 09 / 95$ & 3.1 & 0.1 & 131 & 12 & 9.4 & 2.0 & 0.1 & $<0.1$ & 48 & 3.8 & 12 & 0.6 \\
\hline AR31.0 & $01 / 09 / 95$ & 0.8 & 0.1 & 0.3 & 0.1 & 0.1 & $<0.1$ & $<0.1$ & $<0.1$ & 0.6 & 0.1 & 0.1 & $<0.1$ \\
\hline AR34.5 & $01 / 10 / 95$ & 3.1 & 0.1 & 131 & 12 & 9.4 & 2.0 & 0.1 & $<0.1$ & 48 & 3.8 & 12 & 0.6 \\
\hline AR31.0 & $01 / 10 / 95$ & 0.9 & 0.1 & 0.3 & 0.1 & 0.1 & $<0.1$ & $<0.1$ & $<0.1$ & 0.6 & 0.1 & 0.1 & $<0.1$ \\
\hline AR34.5 & $01 / 11 / 95$ & 3.1 & 0.1 & 131 & 12 & 9.4 & 2.0 & 0.1 & $<0.1$ & 48 & 3.8 & 12 & 0.6 \\
\hline AR31.0 & $01 / 11 / 95$ & 0.9 & 0.1 & 0.3 & 0.1 & 0.1 & $<0.1$ & $<0.1$ & $<0.1$ & 0.6 & 0.1 & 0.2 & $<0.1$ \\
\hline AR34.5 & $01 / 12 / 95$ & 3.3 & 0.1 & 140 & 12 & 10 & 2.1 & 0.1 & $<0.1$ & 52 & 4.0 & 13 & 0.7 \\
\hline AR31.0 & $01 / 12 / 95$ & 0.9 & 0.1 & 0.3 & 0.1 & 0.1 & $<0.1$ & $<0.1$ & $<0.1$ & 0.6 & 0.1 & 0.2 & $<0.1$ \\
\hline AR34.5 & $01 / 13 / 95$ & 3.3 & 0.1 & 140 & 12 & 10 & 2.1 & 0.1 & $<0.1$ & 52 & 4.0 & 13 & 0.7 \\
\hline AR31.0 & $01 / 13 / 95$ & 0.9 & 0.1 & 0.3 & 0.1 & 0.1 & $<0.1$ & $<0.1$ & $<0.1$ & 0.6 & 0.1 & 0.2 & $<0.1$ \\
\hline AR34.5 & $01 / 14 / 95$ & 3.3 & 0.1 & 140 & 12 & 10 & 2.1 & 0.1 & $<0.1$ & 52 & 4.0 & 13 & 0.7 \\
\hline AR31.0 & $01 / 14 / 95$ & 0.9 & 0.1 & 0.3 & 0.1 & 0.1 & $<0.1$ & $<0.1$ & $<0.1$ & 0.6 & 0.1 & 0.2 & $<0.1$ \\
\hline AR34.5 & $01 / 15 / 95$ & 3.3 & 0.1 & 140 & 12 & 10 & 2.1 & 0.1 & $<0.1$ & 52 & 4.0 & 13 & 0.7 \\
\hline AR31.0 & $01 / 15 / 95$ & 0.9 & 0.1 & 0.3 & 0.1 & 0.1 & $<0.1$ & $<0.1$ & $<0.1$ & 0.6 & 0.1 & 0.2 & $<0.1$ \\
\hline AR34.5 & $01 / 16 / 95$ & 3.3 & 0.1 & 140 & 12 & 10 & 2.1 & 0.1 & $<0.1$ & 52 & 4.0 & 13 & 0.7 \\
\hline AR31.0 & $01 / 16 / 95$ & 0.9 & 0.1 & 0.3 & 0.1 & 0.1 & $<0.1$ & $<0.1$ & $<0.1$ & 0.6 & 0.1 & 0.2 & $<0.1$ \\
\hline AR34.5 & $01 / 17 / 95$ & 3.5 & 0.1 & 149 & 13 & 11 & 2.3 & 0.1 & $<0.1$ & 55 & 4.3 & 14 & 0.7 \\
\hline AR31.0 & $01 / 17 / 95$ & 0.9 & 0.1 & 0.3 & 0.1 & 0.1 & $<0.1$ & $<0.1$ & $<0.1$ & 0.6 & 0.1 & 0.2 & $<0.1$ \\
\hline AR34.5 & $01 / 18 / 95$ & 3.5 & 0.1 & 149 & 13 & 11 & 2.3 & 0.1 & $<0.1$ & 55 & 4.3 & 14 & 0.7 \\
\hline AR31.0 & $01 / 18 / 95$ & 0.9 & 0.1 & 0.3 & 0.1 & 0.1 & $<0.1$ & $<0.1$ & $<0.1$ & 0.6 & 0.1 & 0.2 & $<0.1$ \\
\hline
\end{tabular}


Table 6. Estimated daily dissolved-metal loads and standard errors for sites AR34.5 and AR31.0, April 1994 through March 1995-Continued

[Loads and standard errors are in pounds per day; <, less than; --, no data]

\begin{tabular}{|c|c|c|c|c|c|c|c|c|c|c|c|c|c|}
\hline \multirow[b]{2}{*}{ Site } & \multirow[b]{2}{*}{ Date } & \multicolumn{2}{|c|}{ Aluminum } & \multicolumn{2}{|c|}{ Iron } & \multicolumn{2}{|c|}{ Copper } & \multicolumn{2}{|c|}{ Cadmium } & \multicolumn{2}{|c|}{ Manganese } & \multicolumn{2}{|c|}{ Zine } \\
\hline & & Load & $\begin{array}{l}\text { Standard } \\
\text { error }\end{array}$ & Load & $\begin{array}{l}\text { Standard } \\
\text { error }\end{array}$ & Load & $\begin{array}{l}\text { Standard } \\
\text { error }\end{array}$ & Load & $\begin{array}{l}\text { Standard } \\
\text { error }\end{array}$ & Load & $\begin{array}{l}\text { Standard } \\
\text { error }\end{array}$ & Load & $\begin{array}{l}\text { Standard } \\
\text { error }\end{array}$ \\
\hline$\overline{\mathrm{AR} 34.5}$ & $01 / 19 / 95$ & 3.5 & 0.1 & 149 & 13 & 11 & 2.3 & 0.1 & $<0.1$ & 55 & 4.3 & 14 & 0.7 \\
\hline AR31.0 & $01 / 19 / 95$ & 0.9 & 0.1 & 0.3 & 0.1 & 0.1 & $<0.1$ & $<0.1$ & $<0.1$ & 0.6 & 0.1 & 0.2 & $<0.1$ \\
\hline AR34.5 & $01 / 20 / 95$ & 3.5 & 0.1 & 149 & 13 & 11 & 2.3 & 0.1 & $<0.1$ & 55 & 4.3 & 14 & 0.7 \\
\hline AR31.0 & $01 / 20 / 95$ & 0.9 & 0.1 & 0.3 & 0.1 & 0.1 & $<0.1$ & $<0.1$ & $<0.1$ & 0.6 & 0.1 & 0.2 & $<0.1$ \\
\hline AR34.5 & $01 / 21 / 95$ & 3.5 & 0.1 & 149 & 13 & 11 & 2.3 & 0.1 & $<0.1$ & 55 & 4.3 & 14 & 0.7 \\
\hline AR31.0 & $01 / 21 / 95$ & 0.9 & 0.1 & 0.3 & 0.1 & 0.1 & $<0.1$ & $<0.1$ & $<0.1$ & 0.6 & 0.1 & 0.2 & $<0.1$ \\
\hline AR34.5 & $01 / 22 / 95$ & 3.7 & 0.2 & 158 & 14 & 11 & 2.4 & 0.1 & $<0.1$ & 58 & 4.6 & 15 & 0.8 \\
\hline AR31.0 & $01 / 22 / 95$ & 0.9 & 0.1 & 0.3 & 0.1 & 0.1 & $<0.1$ & $<0.1$ & $<0.1$ & 0.6 & 0.1 & 0.2 & $<0.1$ \\
\hline AR34.5 & $01 / 23 / 95$ & 3.7 & 0.2 & 158 & 14 & 11 & 2.4 & 0.1 & $<0.1$ & 58 & 4.6 & 15 & 0.8 \\
\hline AR31.0 & $01 / 23 / 95$ & 0.9 & 0.1 & 0.3 & 0.1 & 0.1 & $<0.1$ & $<0.1$ & $<0.1$ & 0.6 & 0.1 & 0.2 & $<0.1$ \\
\hline AR34.5 & $01 / 24 / 95$ & 3.7 & 0.2 & 158 & 14 & 11 & 2.4 & 0.1 & $<0.1$ & 58 & 4.6 & 15 & 0.8 \\
\hline AR31.0 & $01 / 24 / 95$ & 0.9 & 0.1 & 0.3 & 0.1 & 0.1 & $<0.1$ & $<0.1$ & $<0.1$ & 0.6 & 0.1 & 0.2 & $<0.1$ \\
\hline AR34.5 & $01 / 25 / 95$ & 3.7 & 0.2 & 158 & 14 & 11 & 2.4 & 0.1 & $<0.1$ & 58 & 4.6 & 15 & 0.8 \\
\hline AR31.0 & $01 / 25 / 95$ & 0.9 & 0.1 & 0.3 & 0.1 & 0.1 & $<0.1$ & $<0.1$ & $<0.1$ & 0.6 & 0.1 & 0.2 & $<0.1$ \\
\hline AR34.5 & $01 / 26 / 95$ & 3.9 & 0.2 & 166 & 14 & 12 & 2.5 & 0.1 & $<0.1$ & 61 & 4.8 & 15 & 0.8 \\
\hline AR31.0 & $01 / 26 / 95$ & 0.9 & 0.1 & 0.3 & 0.1 & 0.1 & $<0.1$ & $<0.1$ & $<0.1$ & 0.6 & 0.1 & 0.2 & $<0.1$ \\
\hline AR34.5 & $01 / 27 / 95$ & 3.9 & 0.2 & 166 & 14 & 12 & 2.5 & 0.1 & $<0.1$ & 61 & 4.8 & 15 & 0.8 \\
\hline AR31.0 & $01 / 27 / 95$ & 0.9 & 0.1 & 0.3 & 0.1 & 0.1 & $<0.1$ & $<0.1$ & $<0.1$ & 0.6 & 0.1 & 0.2 & $<0.1$ \\
\hline AR34.5 & $01 / 28 / 95$ & 4.1 & 0.2 & 175 & 15 & 12 & 2.7 & 0.1 & $<0.1$ & 64 & 5.1 & 16 & 0.8 \\
\hline AR31.0 & $01 / 28 / 95$ & 0.9 & 0.1 & 0.3 & 0.1 & 0.1 & $<0.1$ & $<0.1$ & $<0.1$ & 0.6 & 0.1 & 0.2 & $<0.1$ \\
\hline AR34.5 & $01 / 29 / 95$ & 4.1 & 0.2 & 175 & 15 & 12 & 2.7 & 0.1 & $<0.1$ & 64 & 5.1 & 16 & 0.8 \\
\hline AR31.0 & $01 / 29 / 95$ & 0.9 & 0.1 & 0.3 & 0.1 & 0.1 & $<0.1$ & $<0.1$ & $<0.1$ & 0.6 & 0.1 & 0.2 & $<0.1$ \\
\hline AR34.5 & $01 / 30 / 95$ & 4.1 & 0.2 & 175 & 15 & 12 & 2.7 & 0.1 & $<0.1$ & 64 & 5.1 & 16 & 0.8 \\
\hline AR31.0 & $01 / 30 / 95$ & 0.9 & 0.1 & 0.3 & 0.1 & 0.1 & $<0.1$ & $<0.1$ & $<0.1$ & 0.6 & 0.1 & 0.2 & $<0.1$ \\
\hline AR34.5 & $01 / 31 / 95$ & 4.1 & 0.2 & 175 & 15 & 12 & 2.7 & 0.1 & $<0.1$ & 64 & 5.1 & 16 & 0.8 \\
\hline AR31.0 & $01 / 31 / 95$ & 0.9 & 0.1 & 0.3 & 0.1 & 0.1 & $<0.1$ & $<0.1$ & $<0.1$ & 0.6 & 0.1 & 0.2 & $<0.1$ \\
\hline AR34.5 & $02 / 01 / 95$ & 4.1 & 0.2 & 175 & 15 & 12 & 2.7 & 0.1 & $<0.1$ & 64 & 5.1 & 16 & 0.8 \\
\hline AR31.0 & $02 / 01 / 95$ & 0.9 & 0.1 & 0.3 & 0.1 & 0.1 & $<0.1$ & $<0.1$ & $<0.1$ & 0.6 & 0.1 & 0.2 & $<0.1$ \\
\hline AR34.5 & $02 / 02 / 95$ & 4.3 & 0.2 & 184 & 16 & 13 & 2.8 & 0.1 & $<0.1$ & 68 & 5.3 & 17 & 0.9 \\
\hline AR31.0 & $02 / 02 / 95$ & 0.9 & 0.1 & 0.3 & 0.1 & 0.1 & $<0.1$ & $<0.1$ & $<0.1$ & 0.6 & 0.1 & 0.2 & $<0.1$ \\
\hline AR34.5 & $02 / 03 / 95$ & 4.3 & 0.2 & 184 & 16 & 13 & 2.8 & 0.1 & $<0.1$ & 68 & 5.3 & 17 & 0.9 \\
\hline AR31.0 & $02 / 03 / 95$ & 0.9 & 0.1 & 0.3 & 0.1 & 0.1 & $<0.1$ & $<0.1$ & $<0.1$ & 0.6 & 0.1 & 0.2 & $<0.1$ \\
\hline AR34.5 & 02/04/95 & 4.6 & 0.2 & 193 & 17 & 14 & 2.9 & 0.1 & $<0.1$ & 71 & 5.6 & 18 & 0.9 \\
\hline AR31.0 & $02 / 04 / 95$ & 0.9 & 0.1 & 0.3 & 0.1 & 0.1 & $<0.1$ & $<0.1$ & $<0.1$ & 0.6 & 0.1 & 0.2 & $<0.1$ \\
\hline AR34.5 & $02 / 05 / 95$ & 4.8 & 0.2 & 201 & 18 & 14 & 3.1 & 0.1 & $<0.1$ & 74 & 5.8 & 19 & 1.0 \\
\hline AR31.0 & $02 / 05 / 95$ & 0.9 & 0.1 & 0.3 & 0.1 & 0.1 & $<0.1$ & $<0.1$ & $<0.1$ & 0.6 & 0.1 & 0.2 & $<0.1$ \\
\hline AR34.5 & $02 / 06 / 95$ & 4.8 & 0.2 & 201 & 18 & 14 & 3.1 & 0.1 & $<0.1$ & 74 & 5.8 & 19 & 1.0 \\
\hline AR31.0 & $02 / 06 / 95$ & 1.0 & 0.1 & 0.3 & 0.1 & 0.1 & $<0.1$ & $<0.1$ & $<0.1$ & 0.7 & 0.1 & 0.2 & $<0.1$ \\
\hline AR34.5 & $02 / 07 / 95$ & 5.0 & 0.2 & 210 & 18 & 15 & 3.2 & 0.1 & $<0.1$ & 77 & 6.1 & 20 & 1.0 \\
\hline AR31.0 & $02 / 07 / 95$ & 1.0 & 0.1 & 0.3 & 0.1 & 0.1 & $<0.1$ & $<0.1$ & $<0.1$ & 0.7 & 0.1 & 0.2 & $<0.1$ \\
\hline AR34.5 & $02 / 08 / 95$ & 5.0 & 0.2 & 210 & 18 & 15 & 3.2 & 0.1 & $<0.1$ & 77 & 6.1 & 20 & 1.0 \\
\hline AR31.0 & $02 / 08 / 95$ & 1.0 & 0.1 & 0.3 & 0.1 & 0.1 & $<0.1$ & $<0.1$ & $<0.1$ & 0.7 & 0.1 & 0.2 & $<0.1$ \\
\hline
\end{tabular}


Table 6. Estimated daily dissolved-metal loads and standard errors for sites AR34.5 and AR31.0, April 1994 through March 1995-Continued

[Loads and standard errors are in pounds per day; $<$, less than; --, no data]

\begin{tabular}{|c|c|c|c|c|c|c|c|c|c|c|c|c|c|}
\hline \multirow[b]{2}{*}{ Site } & \multirow[b]{2}{*}{ Date } & \multicolumn{2}{|c|}{ Aluminum } & \multicolumn{2}{|c|}{ Iron } & \multicolumn{2}{|c|}{ Copper } & \multicolumn{2}{|c|}{ Cadmlum } & \multicolumn{2}{|c|}{ Manganese } & \multicolumn{2}{|c|}{ Zlnc } \\
\hline & & Load & $\begin{array}{l}\text { Standard } \\
\text { error }\end{array}$ & Load & $\begin{array}{l}\text { Standard } \\
\text { error }\end{array}$ & Load & $\begin{array}{l}\text { Standard } \\
\text { error }\end{array}$ & Load & $\begin{array}{l}\text { Standard } \\
\text { error }\end{array}$ & Load & $\begin{array}{l}\text { Standard } \\
\text { error }\end{array}$ & Load & $\begin{array}{l}\text { Standard } \\
\text { error }\end{array}$ \\
\hline$\overline{\text { AR34.5 }}$ & $02 / 09 / 95$ & 5.2 & 0.2 & 219 & 19 & 16 & $\overline{3.3}$ & 0.1 & $<0.1$ & 81 & 6.3 & 20 & 1.0 \\
\hline AR31.0 & $02 / 09 / 95$ & 1.1 & 0.1 & 0.3 & 0.1 & 0.1 & $<0.1$ & $<0.1$ & $<0.1$ & 0.7 & 0.1 & 0.2 & $<0.1$ \\
\hline AR34.5 & $02 / 10 / 95$ & 5.2 & 0.2 & 219 & 19 & 16 & 3.3 & 0.1 & $<0.1$ & 81 & 6.3 & 20 & 1.0 \\
\hline AR31.0 & $02 / 10 / 95$ & 1.1 & 0.1 & 0.3 & 0.1 & 0.1 & $<0.1$ & $<0.1$ & $<0.1$ & 0.7 & 0.1 & 0.2 & $<0.1$ \\
\hline AR34.5 & $02 / 11 / 95$ & 5.2 & 0.2 & 219 & 19 & 16 & 3.3 & 0.1 & $<0.1$ & 81 & 6.3 & 20 & 1.0 \\
\hline AR31.0 & $02 / 11 / 95$ & 1.1 & 0.1 & 0.3 & 0.1 & 0.1 & $<0.1$ & $<0.1$ & $<0.1$ & 0.7 & 0.1 & 0.2 & $<0.1$ \\
\hline AR34.5 & $02 / 12 / 95$ & 5.2 & 0.2 & 219 & 19 & 16 & 3.3 & 0.1 & $<0.1$ & 81 & 6.3 & 20 & 1.0 \\
\hline AR31.0 & $02 / 12 / 95$ & 1.1 & 0.1 & 0.3 & 0.1 & 0.1 & $<0.1$ & $<0.1$ & $<0.1$ & 0.7 & 0.1 & 0.2 & $<0.1$ \\
\hline AR34.5 & $02 / 13 / 95$ & 5.4 & 0.2 & 228 & 20 & 16 & 3.5 & 0.2 & $<0.1$ & 84 & 6.6 & 21 & 1.1 \\
\hline AR31.0 & $02 / 13 / 95$ & 1.1 & 0.1 & 0.4 & 0.1 & 0.1 & $<0.1$ & $<0.1$ & $<0.1$ & 0.8 & 0.1 & 0.2 & $<0.1$ \\
\hline AR34.5 & $02 / 14 / 95$ & 5.4 & 0.2 & 228 & 20 & 16 & 3.5 & 0.2 & $<0.1$ & 84 & 6.6 & 21 & 1.1 \\
\hline AR31.0 & $02 / 14 / 95$ & 1.1 & 0.1 & 0.4 & 0.1 & 0.1 & $<0.1$ & $<0.1$ & $<0.1$ & 0.8 & 0.1 & 0.2 & $<0.1$ \\
\hline AR34.5 & $02 / 15 / 95$ & 5.6 & 0.2 & 236 & 21 & 17 & 3.6 & 0.2 & $<0.1$ & 87 & 6.8 & 22 & 1.1 \\
\hline AR31.0 & $02 / 15 / 95$ & 1.1 & 0.1 & 0.4 & 0.1 & 0.1 & $<0.1$ & $<0.1$ & $<0.1$ & 0.8 & 0.1 & 0.2 & $<0.1$ \\
\hline AR34.5 & $02 / 16 / 95$ & 5.6 & 0.2 & 236 & 21 & 17 & 3.6 & 0.2 & $<0.1$ & 87 & 6.8 & 22 & 1.1 \\
\hline AR31.0 & $02 / 16 / 95$ & 1.2 & 0.1 & 0.4 & 0.1 & 0.1 & $<0.1$ & $<0.1$ & $<0.1$ & 0.8 & 0.1 & 0.2 & $<0.1$ \\
\hline AR34.5 & $02 / 17 / 95$ & 5.6 & 0.2 & 236 & 21 & 17 & 3.6 & 0.2 & $<0.1$ & 87 & 6.8 & 22 & 1.1 \\
\hline AR31.0 & $02 / 17 / 95$ & 1.2 & 0.1 & 0.4 & 0.1 & 0.2 & $<0.1$ & $<0.1$ & $<0.1$ & 0.8 & 0.1 & 0.2 & $<0.1$ \\
\hline AR34.5 & $02 / 18 / 95$ & 5.8 & 0.2 & 245 & 21 & 18 & 3.7 & 0.2 & $<0.1$ & 90 & 7.1 & 23 & 1.2 \\
\hline AR31.0 & $02 / 18 / 95$ & 1.2 & 0.1 & 0.4 & 0.1 & 0.2 & $<0.1$ & $<0.1$ & $<0.1$ & 0.8 & 0.1 & 0.2 & $<0.1$ \\
\hline AR34.5 & $02 / 19 / 95$ & 5.8 & 0.2 & 245 & 21 & 18 & 3.7 & 0.2 & $<0.1$ & 90 & 7.1 & 23 & 1.2 \\
\hline AR31.0 & $02 / 19 / 95$ & 1.2 & 0.1 & 0.4 & 0.1 & 0.2 & $<0.1$ & $<0.1$ & $<0.1$ & 0.8 & 0.1 & 0.2 & $<0.1$ \\
\hline AR34.5 & $02 / 20 / 95$ & 6.0 & 0.3 & 254 & 22 & 18 & 3.9 & 0.2 & $<0.1$ & 94 & 7.3 & 24 & 1.2 \\
\hline AR31.0 & $02 / 20 / 95$ & 1.2 & 0.1 & 0.4 & 0.1 & 0.2 & $<0.1$ & $<0.1$ & $<0.1$ & 0.8 & 0.1 & 0.2 & $<0.1$ \\
\hline AR34.5 & $02 / 21 / 95$ & 6.0 & 0.3 & 254 & 22 & 18 & 3.9 & 0.2 & $<0.1$ & 94 & 7.3 & 24 & 1.2 \\
\hline AR31.0 & $02 / 21 / 95$ & 1.2 & 0.1 & 0.4 & 0.1 & 0.2 & $<0.1$ & $<0.1$ & $<0.1$ & 0.8 & 0.1 & 0.2 & $<0.1$ \\
\hline AR34.5 & $02 / 22 / 95$ & 6.0 & 0.3 & 254 & 22 & 18 & 3.9 & 0.2 & $<0.1$ & 94 & 7.3 & 24 & 1.2 \\
\hline AR31.0 & $02 / 22 / 95$ & 1.2 & 0.1 & 0.4 & 0.1 & 0.2 & $<0.1$ & $<0.1$ & $<0.1$ & 0.8 & 0.1 & 0.2 & $<0.1$ \\
\hline AR34.5 & $02 / 23 / 95$ & 6.2 & 0.3 & 263 & 23 & 19 & 4.0 & 0.2 & $<0.1$ & 97 & 7.6 & 24 & 1.3 \\
\hline AR31.0 & $02 / 23 / 95$ & 1.2 & 0.1 & 0.4 & 0.1 & 0.2 & $<0.1$ & $<0.1$ & $<0.1$ & 0.8 & 0.1 & 0.2 & $<0.1$ \\
\hline AR34.5 & $02 / 24 / 95$ & 6.4 & 0.3 & 271 & 24 & 19 & 4.1 & 0.2 & $<0.1$ & 100 & 7.8 & 25 & 1.3 \\
\hline AR31.0 & $02 / 24 / 95$ & 1.2 & 0.1 & 0.4 & 0.1 & 0.2 & $<0.1$ & $<0.1$ & $<0.1$ & 0.9 & 0.1 & 0.2 & $<0.1$ \\
\hline AR34.5 & $02 / 25 / 95$ & 6.4 & 0.3 & 271 & 24 & 19 & 4.1 & 0.2 & $<0.1$ & 100 & 7.8 & 25 & 1.3 \\
\hline AR31.0 & $02 / 25 / 95$ & 1.2 & 0.1 & 0.4 & 0.1 & 0.2 & $<0.1$ & $<0.1$ & $<0.1$ & 0.9 & 0.1 & 0.2 & $<0.1$ \\
\hline AR34.5 & $02 / 26 / 95$ & 6.6 & 0.3 & 280 & 24 & 20 & 4.3 & 0.2 & $<0.1$ & 103 & 8.1 & 26 & 1.3 \\
\hline AR31.0 & $02 / 26 / 95$ & 1.2 & 0.1 & 0.4 & 0.1 & 0.2 & $<0.1$ & $<0.1$ & $<0.1$ & 0.9 & 0.1 & 0.2 & $<0.1$ \\
\hline AR34.5 & $02 / 27 / 95$ & 6.8 & 0.3 & 289 & 25 & 21 & 4.4 & 0.2 & $<0.1$ & 106 & 8.3 & 27 & 1.4 \\
\hline AR31.0 & $02 / 27 / 95$ & 1.3 & 0.1 & 0.4 & 0.1 & 0.2 & $<0.1$ & $<0.1$ & $<0.1$ & 0.9 & 0.1 & 0.2 & $<0.1$ \\
\hline AR34.5 & $02 / 28 / 95$ & 7.0 & 0.3 & 298 & 26 & 21 & 4.5 & 0.2 & $<0.1$ & 110 & 8.6 & 28 & 1.4 \\
\hline AR31.0 & $02 / 28 / 95$ & 1.3 & 0.1 & 0.4 & 0.1 & 0.2 & $<0.1$ & $<0.1$ & $<0.1$ & 0.9 & 0.1 & 0.2 & $<0.1$ \\
\hline AR34.5 & $03 / 01 / 95$ & 7.2 & 0.3 & 306 & 27 & 22 & 4.7 & 0.2 & $<0.1$ & 113 & 8.9 & 28 & 1.5 \\
\hline AR31.0 & $03 / 01 / 95$ & 1.3 & 0.1 & 0.4 & 0.1 & 0.2 & $<0.1$ & $<0.1$ & $<0.1$ & 0.9 & 0.1 & 0.2 & $<0.1$ \\
\hline
\end{tabular}


Table 6. Estimated daily dissolved-metal loads and standard errors for sites AR34.5 and AR31.0, April 1994 through March 1995-Continued

[Loads and standard errors are in pounds per day; <, less than; --, no data]

\begin{tabular}{|c|c|c|c|c|c|c|c|c|c|c|c|c|c|}
\hline \multirow[b]{2}{*}{ Site } & \multirow[b]{2}{*}{ Date } & \multicolumn{2}{|c|}{ Aluminum } & \multicolumn{2}{|c|}{ Iron } & \multicolumn{2}{|c|}{ Copper } & \multicolumn{2}{|c|}{ Cadmlum } & \multicolumn{2}{|c|}{ Manganese } & \multicolumn{2}{|c|}{ Zlne } \\
\hline & & Load & $\begin{array}{l}\text { Standard } \\
\text { error }\end{array}$ & Load & $\begin{array}{c}\text { Standard } \\
\text { error }\end{array}$ & Load & $\begin{array}{c}\text { Standard } \\
\text { orror }\end{array}$ & Load & $\begin{array}{l}\text { Standard } \\
\text { error }\end{array}$ & Load & $\begin{array}{c}\text { Standard } \\
\text { error }\end{array}$ & Load & $\begin{array}{l}\text { Standard } \\
\text { error }\end{array}$ \\
\hline$\overline{\mathrm{AR} 34.5}$ & $03 / 02 / 95$ & 7.2 & 0.3 & 306 & 27 & 22 & 4.7 & 0.2 & $<0.1$ & 113 & 8.9 & 28 & 1.5 \\
\hline AR31.0 & $03 / 02 / 95$ & 1.3 & 0.1 & 0.4 & 0.1 & 0.2 & $<0.1$ & $<0.1$ & $<0.1$ & 0.9 & 0.1 & 0.2 & $<0.1$ \\
\hline AR34.5 & $03 / 03 / 95$ & 7.5 & 0.3 & 315 & 28 & 22.6 & 4.8 & 0.2 & $<0.1$ & 116 & 9.1 & 29.2 & 1.5 \\
\hline AR31.0 & $03 / 03 / 95$ & 1.3 & 0.1 & 0.4 & 0.1 & 0.2 & $<0.1$ & $<0.1$ & $<0.1$ & 0.9 & 0.1 & 0.2 & $<0.1$ \\
\hline AR34.5 & $03 / 04 / 95$ & 7.5 & 0.3 & 315 & 28 & 22.6 & 4.8 & 0.2 & $<0.1$ & 116 & 9.1 & 29 & 1.5 \\
\hline AR31.0 & $03 / 04 / 95$ & 1.3 & 0.1 & 0.4 & 0.1 & 0.2 & $<0.1$ & $<0.1$ & $<0.1$ & 0.9 & 0.1 & 0.2 & $<0.1$ \\
\hline AR34.5 & $03 / 05 / 95$ & 7.7 & 0.3 & 324 & 28 & 23.2 & 4.9 & 0.2 & $<0.1$ & 119 & 9.4 & 30 & 1.5 \\
\hline AR31.0 & $03 / 05 / 95$ & 1.3 & 0.1 & 0.4 & 0.1 & 0.2 & $<0.1$ & $<0.1$ & $<0.1$ & 0.9 & 0.1 & 0.2 & $<0.1$ \\
\hline AR34.5 & $03 / 06 / 95$ & 7.9 & 0.3 & 333 & 29 & 23.8 & 5.1 & 0.2 & $<0.1$ & 122 & 9.6 & 31 & 1.6 \\
\hline AR31.0 & $03 / 06 / 95$ & 1.3 & 0.1 & 0.4 & 0.1 & 0.2 & $<0.1$ & $<0.1$ & $<0.1$ & 0.9 & 0.1 & 0.2 & $<0.1$ \\
\hline AR34.5 & $03 / 07 / 95$ & 7.9 & 0.3 & 333 & 29 & 23.8 & 5.1 & 0.2 & $<0.1$ & 122 & 9.6 & 31 & 1.6 \\
\hline AR31.0 & $03 / 07 / 95$ & 1.3 & 0.1 & 0.4 & 0.1 & 0.2 & $<0.1$ & $<0.1$ & $<0.1$ & 0.9 & 0.1 & 0.2 & $<0.1$ \\
\hline AR34.5 & $03 / 08 / 95$ & 8.1 & 0.3 & 342 & 30 & 24.5 & 5.2 & 0.2 & $<0.1$ & 126 & 9.9 & 32 & 1.6 \\
\hline AR31.0 & 03/08/95 & 1.3 & 0.1 & 0.4 & 0.1 & 0.2 & $<0.1$ & $<0.1$ & $<0.1$ & 0.9 & 0.1 & 0.2 & $<0.1$ \\
\hline AR34.5 & 03/09/95 & 8.1 & 0.3 & 342 & 30 & 24.5 & 5.2 & 0.2 & $<0.1$ & 126 & 9.9 & 32 & 1.6 \\
\hline AR31.0 & $03 / 09 / 95$ & 1.4 & 0.1 & 0.4 & 0.1 & 0.2 & $<0.1$ & $<0.1$ & $<0.1$ & 0.9 & 0.2 & 0.2 & $<0.1$ \\
\hline AR34.5 & $03 / 10 / 95$ & 8.3 & 0.3 & 350 & 31 & 25 & 5.3 & 0.2 & $<0.1$ & 129 & 10 & 32 & 1.7 \\
\hline AR31.0 & $03 / 10 / 95$ & 1.4 & 0.1 & 0.4 & 0.1 & 0.2 & $<0.1$ & $<0.1$ & $<0.1$ & 0.9 & 0.2 & 0.2 & $<0.1$ \\
\hline AR34.5 & $03 / 11 / 95$ & 8.3 & 0.3 & 350 & 31 & 25 & 5.3 & 0.2 & $<0.1$ & 129 & 10 & 32 & 1.7 \\
\hline AR31.0 & $03 / 11 / 95$ & 1.4 & 0.1 & 0.4 & 0.1 & 0.2 & $<0.1$ & $<0.1$ & $<0.1$ & 0.9 & 0.2 & 0.2 & $<0.1$ \\
\hline AR34.5 & $03 / 12 / 95$ & 8.5 & 0.4 & 359 & 31 & 26 & 5.5 & 0.2 & $<0.1$ & 132 & 10 & 33 & 1.7 \\
\hline AR31.0 & $03 / 12 / 95$ & 1.4 & 0.1 & 0.4 & 0.1 & 0.2 & $<0.1$ & $<0.1$ & $<0.1$ & 1.0 & 0.2 & 0.2 & $<0.1$ \\
\hline AR34.5 & $03 / 13 / 95$ & 8.7 & 0.4 & 368 & 32 & 26 & 5.6 & 0.2 & $<0.1$ & 135 & 11 & 34 & 1.8 \\
\hline AR31.0 & $03 / 13 / 95$ & 1.4 & 0.1 & 0.5 & 0.1 & 0.2 & $<0.1$ & $<0.1$ & $<0.1$ & 1.0 & 0.2 & 0.2 & $<0.1$ \\
\hline AR34.5 & $03 / 14 / 95$ & 8.9 & 0.4 & 376 & 33 & 27 & 5.7 & 0.3 & $<0.1$ & 139 & 11 & 35 & 1.8 \\
\hline AR31.0 & $03 / 14 / 95$ & 1.4 & 0.1 & 0.5 & 0.1 & 0.2 & $<0.1$ & $<0.1$ & $<0.1$ & 1.0 & 0.2 & 0.2 & $<0.1$ \\
\hline AR34.5 & $03 / 15 / 95$ & 8.9 & 0.4 & 376 & 33 & 27 & 5.7 & 0.3 & $<0.1$ & 139 & 11 & 35 & 1.8 \\
\hline AR31.0 & $03 / 15 / 95$ & 1.4 & 0.1 & 0.5 & 0.1 & 0.2 & $<0.1$ & $<0.1$ & $<0.1$ & 1.0 & 0.2 & 0.2 & $<0.1$ \\
\hline AR34.5 & $03 / 16 / 95$ & 9.1 & 0.4 & 385 & 34 & 28 & 5.9 & 0.3 & $<0.1$ & 142 & 11 & 36 & 1.8 \\
\hline AR31.0 & $03 / 16 / 95$ & 1.4 & 0.1 & 0.5 & 0.1 & 0.2 & $<0.1$ & $<0.1$ & $<0.1$ & 1.0 & 0.2 & 0.2 & $<0.1$ \\
\hline AR34.5 & $03 / 17 / 95$ & 9.3 & 0.4 & 394 & 34 & 28 & 6.0 & 0.3 & $<0.1$ & 145 & 11 & 36 & 1.9 \\
\hline AR31.0 & $03 / 17 / 95$ & 1.4 & 0.1 & 0.5 & 0.1 & 0.2 & $<0.1$ & $<0.1$ & $<0.1$ & 1.0 & 0.2 & 0.2 & $<0.1$ \\
\hline AR34.5 & $03 / 18 / 95$ & 9.3 & 0.4 & 394 & 34 & 28 & 6.0 & 0.3 & $<0.1$ & 145 & 11 & 36 & 1.9 \\
\hline AR31.0 & $03 / 18 / 95$ & 1.5 & 0.1 & 0.5 & 0.1 & 0.2 & $<0.1$ & $<0.1$ & $<0.1$ & 1.0 & 0.2 & 0.3 & $<0.1$ \\
\hline AR34.5 & $03 / 19 / 95$ & 9.5 & 0.4 & 403 & 35 & 29 & 6.1 & 0.3 & $<0.1$ & 148 & 12 & 37 & 1.9 \\
\hline AR31.0 & $03 / 19 / 95$ & 1.6 & 0.1 & 0.5 & 0.1 & 0.2 & $<0.1$ & $<0.1$ & $<0.1$ & 1.1 & 0.2 & 0.3 & $<0.1$ \\
\hline AR34.5 & $03 / 20 / 95$ & 9.7 & 0.4 & 412 & 36 & 30 & 6.3 & 0.3 & $<0.1$ & 152 & 12 & 38 & 2.0 \\
\hline AR31.0 & $03 / 20 / 95$ & 1.6 & 0.1 & 0.5 & 0.1 & 0.2 & $<0.1$ & $<0.1$ & $<0.1$ & 1.1 & 0.2 & 0.3 & $<0.1$ \\
\hline AR34.5 & $03 / 21 / 95$ & 9.7 & 0.4 & 412 & 36 & 30 & 6.3 & 0.3 & $<0.1$ & 152 & 12 & 38 & 2.0 \\
\hline AR31.0 & $03 / 21 / 95$ & 1.6 & 0.1 & 0.5 & 0.1 & 0.2 & $<0.1$ & $<0.1$ & $<0.1$ & 1.1 & 0.2 & 0.3 & $<0.1$ \\
\hline AR34.5 & $03 / 22 / 95$ & 9.9 & 0.4 & 420 & 37 & 30 & 6.4 & 0.3 & $<0.1$ & 155 & 12 & 39 & 2.0 \\
\hline AR31.0 & $03 / 22 / 95$ & 1.6 & 0.1 & 0.5 & 0.1 & 0.2 & $<0.1$ & $<0.1$ & $<0.1$ & 1.1 & 0.2 & 0.3 & $<0.1$ \\
\hline
\end{tabular}


Table 6. Estimated daily dissolved-metal loads and standard errors for sites AR34.5 and AR31.0, April 1994 through March 1995-Continued

[Loads and standard errors are in pounds per day; <, less than; --, no data]

\begin{tabular}{|c|c|c|c|c|c|c|c|c|c|c|c|c|c|}
\hline \multirow[b]{2}{*}{ Site } & \multirow[b]{2}{*}{ Date } & \multicolumn{2}{|c|}{ Aluminum } & \multicolumn{2}{|c|}{ Iron } & \multicolumn{2}{|c|}{ Copper } & \multicolumn{2}{|c|}{ Cadmlum } & \multicolumn{2}{|c|}{ Manganese } & \multicolumn{2}{|c|}{ Zlnc } \\
\hline & & Load & $\begin{array}{l}\text { Standard } \\
\text { error }\end{array}$ & Load & $\begin{array}{l}\text { Standard } \\
\text { error }\end{array}$ & Load & $\begin{array}{c}\text { Standard } \\
\text { error }\end{array}$ & Load & $\begin{array}{l}\text { Standard } \\
\text { error }\end{array}$ & Load & $\begin{array}{l}\text { Standard } \\
\text { error }\end{array}$ & Load & $\begin{array}{c}\text { Standard } \\
\text { error }\end{array}$ \\
\hline$\overline{\text { AR34.5 }}$ & $03 / 23 / 95$ & 10 & 0.4 & 429 & 38 & 31 & 6.5 & 0.3 & $<0.1$ & 158 & 12 & 40 & 2.0 \\
\hline AR31.0 & $03 / 23 / 95$ & 1.6 & 0.1 & 0.5 & 0.1 & 0.2 & $<0.1$ & $<0.1$ & $<0.1$ & 1.1 & 0.2 & 0.3 & $<0.1$ \\
\hline AR34.5 & $03 / 24 / 95$ & 10 & 0.4 & 429 & 38 & 31 & 6.5 & 0.3 & $<0.1$ & 158 & 12 & 40 & 2.0 \\
\hline AR31.0 & $03 / 24 / 95$ & 1.6 & 0.1 & 0.5 & 0.1 & 0.2 & $<0.1$ & $<0.1$ & $<0.1$ & 1.1 & 0.2 & 0.3 & $<0.1$ \\
\hline AR34.5 & $03 / 25 / 95$ & 11 & 0.5 & 482 & 42 & 34 & 7.3 & 0.3 & $<0.1$ & 177 & 14 & 45 & 2.3 \\
\hline AR31.0 & $03 / 25 / 95$ & 1.5 & 0.1 & 0.5 & 0.1 & 0.2 & $<0.1$ & $<0.1$ & $<0.1$ & 1.0 & 0.2 & 0.3 & $<0.1$ \\
\hline AR34.5 & $03 / 26 / 95$ & 12 & 0.5 & 508 & 44 & 36 & 7.7 & 0.3 & $<0.1$ & 187 & 15 & 47 & 2.4 \\
\hline AR31.0 & $03 / 26 / 95$ & 1.4 & 0.1 & 0.5 & 0.1 & 0.2 & $<0.1$ & $<0.1$ & $<0.1$ & 1.0 & 0.2 & 0.2 & $<0.1$ \\
\hline AR34.5 & $03 / 27 / 95$ & 14 & 0.6 & 578 & 50 & 41 & 8.8 & 0.4 & $<0.1$ & 213 & 17 & 54 & 2.8 \\
\hline AR31.0 & $03 / 27 / 95$ & 1.4 & 0.1 & 0.5 & 0.1 & 0.2 & $<0.1$ & $<0.1$ & $<0.1$ & 1.0 & 0.2 & 0.2 & $<0.1$ \\
\hline AR34.5 & $03 / 28 / 95$ & 17 & 0.7 & 709 & 62 & 51 & 11 & 0.5 & $<0.1$ & 261 & 20 & 66 & 3.4 \\
\hline AR31.0 & $03 / 28 / 95$ & 1.4 & 0.1 & 0.5 & 0.1 & 0.2 & $<0.1$ & $<0.1$ & $<0.1$ & 1.0 & 0.2 & 0.2 & $<0.1$ \\
\hline AR34.5 & $03 / 29 / 95$ & 14 & 0.6 & 604 & 53 & 43 & 9.2 & 0.4 & $<0.1$ & 222 & 18 & 56 & 2.9 \\
\hline AR31.0 & $03 / 29 / 95$ & 1.4 & 0.1 & 0.4 & 0.1 & 0.2 & $<0.1$ & $<0.1$ & $<0.1$ & 0.9 & 0.2 & 0.2 & $<0.1$ \\
\hline AR34.5 & $03 / 30 / 95$ & 18 & 0.7 & 744 & 65 & 53 & 11 & 0.5 & $<0.1$ & 274 & 22 & 69 & 3.5 \\
\hline AR31.0 & $03 / 30 / 95$ & 1.4 & 0.1 & 0.4 & 0.1 & 0.2 & $<0.1$ & $<0.1$ & $<0.1$ & 0.9 & 0.2 & 0.2 & $<0.1$ \\
\hline AR34.5 & $03 / 31 / 95$ & 17 & 0.7 & 718 & 63 & 51 & 11 & 0.5 & $<0.1$ & 264 & 21 & 67 & 3.4 \\
\hline AR31.0 & $03 / 31 / 95$ & 1.4 & 0.1 & 0.4 & 0.1 & 0.2 & $<0.1$ & $<0.1$ & $<0.1$ & 0.9 & 0.1 & 0.2 & $<0.1$ \\
\hline
\end{tabular}

Table 7. Estimated daily total-metal loads and standard errors for sites AR34.5 and AR31.0, April 1994 through March 1995

[Loads and standard errors are in pounds per day; <, less than; --, no data]

\begin{tabular}{|c|c|c|c|c|c|c|c|c|c|c|c|c|c|}
\hline \multirow[b]{2}{*}{ Site } & \multirow[b]{2}{*}{ Date } & \multicolumn{2}{|c|}{ Aluminum } & \multicolumn{2}{|c|}{ Iron } & \multicolumn{2}{|c|}{ Copper } & \multicolumn{2}{|c|}{ Cadmium } & \multicolumn{2}{|c|}{ Manganese } & \multicolumn{2}{|c|}{ Zinc } \\
\hline & & Load & $\begin{array}{l}\text { Standard } \\
\text { error }\end{array}$ & Load & $\begin{array}{l}\text { Standard } \\
\text { error }\end{array}$ & Load & $\begin{array}{l}\text { Standard } \\
\text { error }\end{array}$ & Load & $\begin{array}{l}\text { Standard } \\
\text { error }\end{array}$ & Load & $\begin{array}{l}\text { Standard } \\
\text { error }\end{array}$ & Load & $\begin{array}{l}\text { Standard } \\
\text { error }\end{array}$ \\
\hline AR34.5 & $04 / 01 / 94$ & 426 & 55 & 899 & 103 & 20 & 2.0 & $<0.1$ & $<0.1$ & 59 & 4.0 & 14 & 1.4 \\
\hline AR31.0 & $04 / 01 / 94$ & 46 & 16 & 116 & 35 & 8.8 & 0.7 & 0.1 & $<0.1$ & 78 & 3.0 & 19 & 3.2 \\
\hline AR34.5 & $04 / 02 / 94$ & 449 & 58 & 949 & 109 & 21 & 2.1 & $<0.1$ & $<0.1$ & 62 & 4.2 & 14 & 1.5 \\
\hline AR31.0 & $04 / 02 / 94$ & 49 & 17 & 123 & 37 & 9.3 & 0.7 & 0.1 & $<0.1$ & 82 & 3.2 & 20 & 3.4 \\
\hline AR34.5 & $04 / 03 / 94$ & 414 & 54 & 874 & 100 & 19 & 1.9 & $<0.1$ & $<0.1$ & 57 & 3.9 & 13 & 1.4 \\
\hline AR31.0 & $04 / 03 / 94$ & 45 & 16 & 113 & 34 & 8.6 & 0.6 & 0.1 & $<0.1$ & 76 & 2.9 & 19 & 3.1 \\
\hline AR34.5 & $04 / 04 / 94$ & 449 & 58 & 949 & 109 & 21 & 2.1 & $<0.1$ & $<0.1$ & 62 & 4.2 & 14 & 1.5 \\
\hline AR31.0 & $04 / 04 / 94$ & 49 & 17 & 123 & 37 & 9.3 & 0.7 & 0.1 & $<0.1$ & 82 & 3.2 & 20 & 3.4 \\
\hline AR34.5 & $04 / 05 / 94$ & 438 & 57 & 924 & 106 & 20 & 2.1 & $<0.1$ & $<0.1$ & 61 & 4.1 & 14 & 1.5 \\
\hline AR31.0 & $04 / 05 / 94$ & 48 & 17 & 120 & 36 & 9.0 & 0.7 & 0.1 & $<0.1$ & 80 & 3.1 & 20 & 3.3 \\
\hline AR34.5 & $04 / 06 / 94$ & 367 & 48 & 774 & 89 & 17 & 1.7 & $<0.1$ & $<0.1$ & 51 & 3.5 & 12 & 1.2 \\
\hline AR31.0 & $04 / 06 / 94$ & 40 & 14 & 100 & 30 & 7.6 & 0.6 & 0.1 & $<0.1$ & 67 & 2.6 & 17 & 2.7 \\
\hline AR34.5 & $04 / 07 / 94$ & 390 & 51 & 824 & 95 & 18 & 1.8 & $<0.1$ & $<0.1$ & 54 & 3.7 & 12 & 1.3 \\
\hline AR31.0 & $04 / 07 / 94$ & 43 & 15 & 107 & 32 & 8.1 & 0.6 & 0.1 & $<0.1$ & 71 & 2.8 & 18 & 2.9 \\
\hline
\end{tabular}


Table 7. Estimated daily total-metal loads and standard errors for sites AR34.5 and AR31.0, April 1994 through March 1995-Continued

[Loads and standard errors are in pounds per day; $<$, less than; -- , no data]

\begin{tabular}{|c|c|c|c|c|c|c|c|c|c|c|c|c|c|}
\hline \multirow[b]{2}{*}{ Site } & \multirow[b]{2}{*}{ Date } & \multicolumn{2}{|c|}{ Aluminum } & \multicolumn{2}{|c|}{ Iron } & \multicolumn{2}{|c|}{ Copper } & \multicolumn{2}{|c|}{ Cadmium } & \multicolumn{2}{|c|}{ Manganese } & \multicolumn{2}{|c|}{ Zinc } \\
\hline & & Load & $\begin{array}{l}\text { Standard } \\
\text { error }\end{array}$ & Load & $\begin{array}{l}\text { Standard } \\
\text { error }\end{array}$ & Load & $\begin{array}{l}\text { Standard } \\
\text { error }\end{array}$ & Load & $\begin{array}{l}\text { Standard } \\
\text { error }\end{array}$ & Load & $\begin{array}{l}\text { Standard } \\
\text { error }\end{array}$ & Load & $\begin{array}{l}\text { Standard } \\
\text { error }\end{array}$ \\
\hline$\overline{\text { AR34.5 }}$ & $04 / 08 / 94$ & 343 & 45 & 724 & 83 & 16 & 1.6 & $<0.1$ & $<0.1$ & 48 & 3.2 & 11 & 1.2 \\
\hline AR31.0 & $04 / 08 / 94$ & 37 & 13 & 94 & 28 & 7.1 & 0.5 & 0.1 & $<0.1$ & 63 & 2.4 & 16 & 2.6 \\
\hline AR34.5 & $04 / 09 / 94$ & 343 & 45 & 724 & 83 & 16 & 1.6 & $<0.1$ & $<0.1$ & 48 & 3.2 & 11 & 1.2 \\
\hline AR31.0 & $04 / 09 / 94$ & 37 & 13 & 94 & 28 & 7.1 & 0.5 & 0.1 & $<0.1$ & 63 & 2.4 & 16 & 2.6 \\
\hline AR34.5 & $04 / 10 / 94$ & 331 & 43 & 699 & 80 & 15 & 1.6 & $<0.1$ & $<0.1$ & 46 & 3.1 & 11 & 1.1 \\
\hline AR31.0 & $04 / 10 / 94$ & 36 & 13 & 91 & 28 & 6.8 & 0.5 & 0.1 & $<0.1$ & 60 & 2.3 & 15 & 2.5 \\
\hline AR34.5 & $04 / 11 / 94$ & 308 & 40 & 649 & 74 & 14 & 1.4 & $<0.1$ & $<0.1$ & 43 & 2.9 & 9.7 & 1.0 \\
\hline AR31.0 & $04 / 11 / 94$ & 34 & 12 & 84 & 26 & 6.4 & 0.5 & 0.1 & $<0.1$ & 56 & 2.2 & 14.0 & 2.3 \\
\hline AR34.5 & $04 / 12 / 94$ & 284 & 37 & 599 & 69 & 13 & 1.3 & $<0.1$ & $<0.1$ & 39 & 2.7 & 9 & 1.0 \\
\hline AR31.0 & $04 / 12 / 94$ & 31 & 11 & 78 & 24 & 5.9 & 0.4 & 0.1 & $<0.1$ & 52 & 2.0 & 13 & 2.1 \\
\hline AR34.5 & $04 / 13 / 94$ & 331 & 43 & 699 & 80 & 15 & 1.6 & $<0.1$ & $<0.1$ & 46 & 3.1 & 10 & 1.1 \\
\hline AR31.0 & $04 / 13 / 94$ & 36 & 13 & 91 & 28 & 6.8 & 0.5 & 0.1 & $<0.1$ & 60 & 2.3 & 15 & 2.5 \\
\hline AR34.5 & $04 / 14 / 94$ & 426 & 55 & 899 & 103 & 20 & 2.0 & $<0.1$ & $<0.1$ & 59 & 4.0 & 14 & 1.4 \\
\hline AR31.0 & $04 / 14 / 94$ & 46 & 16 & 116 & 35 & 8.8 & 0.7 & 0.1 & $<0.1$ & 78 & 3.0 & 19 & 3.2 \\
\hline AR34.5 & $04 / 15 / 94$ & 473 & 62 & 999 & 115 & 22 & 2.2 & $<0.1$ & $<0.1$ & 66 & 4.5 & 15 & 1.6 \\
\hline AR31.0 & $04 / 15 / 94$ & 52 & 18 & 129 & 39 & 9.8 & 0.7 & 0.1 & $<0.1$ & 86 & 3.3 & 22 & 3.5 \\
\hline AR34.5 & $04 / 16 / 94$ & 627 & 82 & 1,320 & 152 & 29 & 2.9 & $<0.1$ & $<0.1$ & 87 & 5.9 & 20 & 2.1 \\
\hline AR31.0 & $04 / 16 / 94$ & 68 & 24 & 171 & 52 & 13 & 1.0 & 0.2 & $<0.1$ & 115 & 4.4 & 28 & 4.7 \\
\hline AR34.5 & $04 / 17 / 94$ & 934 & 122 & 1,972 & 226 & 43 & 4.4 & $<0.2$ & $<0.1$ & 129 & 8.8 & 30 & 3.1 \\
\hline AR31.0 & $04 / 17 / 94$ & 102 & 36 & 256 & 78 & 19 & 1.4 & 0.2 & $<0.1$ & 171 & 6.6 & 42 & 7.0 \\
\hline AR34.5 & $04 / 18 / 94$ & 1,230 & 160 & 2,600 & 298 & 57 & 5.8 & $<0.3$ & $<0.1$ & 170 & 12 & 39 & 4.1 \\
\hline AR31.0 & $04 / 18 / 94$ & 134 & 47 & 336 & 102 & 25 & 1.9 & 0.3 & $<0.1$ & 225 & 8.7 & 56 & 9.2 \\
\hline AR34.5 & $04 / 19 / 94$ & 1,350 & 175 & 2,850 & 327 & 62 & 6.3 & $<0.3$ & $<0.1$ & 187 & 13 & 43 & 4.5 \\
\hline AR31.0 & $04 / 19 / 94$ & 147 & 51 & 369 & 112 & 28 & 2.1 & 0.3 & $<0.1$ & 246 & 9.5 & 61 & 10 \\
\hline AR34.5 & $04 / 20 / 94$ & 1,510 & 197 & 3,200 & 367 & 70 & 7.1 & $<0.3$ & $<0.1$ & 210 & 14 & 48 & 5.1 \\
\hline AR31.0 & $04 / 20 / 94$ & 175 & 61 & 440 & 134 & 33 & 2.5 & 0.4 & $<0.1$ & 294 & 11 & 73 & 12 \\
\hline AR34.5 & $04 / 21 / 94$ & 1,940 & 252 & 4,090 & 470 & 90 & 9.1 & $<0.4$ & $<0.1$ & 268 & 18 & 61 & 6.5 \\
\hline AR31.0 & $04 / 21 / 94$ & 177 & 62 & 443 & 135 & 34 & 2.5 & 0.4 & $<0.1$ & 296 & 11 & 74 & 12 \\
\hline AR34.5 & $04 / 22 / 94$ & 2,330 & 303 & 4,920 & 564 & 108 & 11 & $<0.5$ & $<0.1$ & 323 & 22 & 74 & 7.8 \\
\hline AR31.0 & $04 / 22 / 94$ & 270 & 94 & 676 & 206 & 51 & 3.8 & 0.6 & $<0.1$ & 452 & 18 & 112 & 18 \\
\hline AR34.5 & $04 / 23 / 94$ & 3,080 & 400 & 6,490 & 745 & 142 & 14 & $<0.7$ & $<0.1$ & 426 & 29 & 97 & 10 \\
\hline AR31.0 & $04 / 23 / 94$ & 328 & 114 & 821 & 250 & 62 & 4.6 & 0.8 & $<0.1$ & 549 & 21 & 136 & 22 \\
\hline AR34.5 & $04 / 24 / 94$ & 3,170 & 412 & 6,690 & 768 & 147 & 15 & $<0.7$ & $<0.1$ & 439 & 30 & 100 & 11 \\
\hline AR31.0 & $04 / 24 / 94$ & 328 & 114 & 821 & 250 & 62 & 4.6 & 0.8 & $<0.1$ & 549 & 21 & 136 & 22 \\
\hline AR34.5 & $04 / 25 / 94$ & 2,480 & 323 & 5,240 & 602 & 115 & 12 & $<0.6$ & $<0.1$ & 344 & 23 & 79 & 8.4 \\
\hline AR31.0 & $04 / 25 / 94$ & 328 & 114 & 821 & 250 & 62 & 4.6 & 0.8 & $<0.1$ & 549 & 21 & 136 & 22 \\
\hline AR34.5 & $04 / 26 / 94$ & 1,870 & 243 & 3,940 & 453 & 86 & 8.8 & $<0.4$ & $<0.1$ & 259 & 18 & 59 & 6.3 \\
\hline AR31.0 & $04 / 26 / 94$ & 250 & 87 & 627 & 191 & 47 & 3.5 & 0.6 & $<0.1$ & 419 & 16 & 104 & 17 \\
\hline AR34.5 & $04 / 27 / 94$ & 1,520 & 198 & 3,220 & 370 & 70 & 7.2 & $<0.3$ & $<0.1$ & 211 & 14 & 48 & 5.1 \\
\hline AR31.0 & $04 / 27 / 94$ & 205 & 72 & 514 & 156 & 39 & 2.9 & 0.5 & $<0.1$ & 344 & 13 & 86 & 14 \\
\hline AR34.5 & $04 / 28 / 94$ & 1,280 & 166 & 2,700 & 309 & 59 & 6.0 & $<0.3$ & $<0.1$ & 177 & 12 & 40 & 4.3 \\
\hline AR31.0 & $04 / 28 / 94$ & 160 & 56 & 401 & 122 & 30 & 2.2 & 0.4 & $<0.1$ & 268 & 10 & 67 & 11 \\
\hline
\end{tabular}


Table 7. Estimated daily total-metal loads and standard errors for sites AR34.5 and AR31.0, April 1994 through March 1995-Continued

[Loads and standard errors are in pounds per day; <, less than; --, no data]

\begin{tabular}{|c|c|c|c|c|c|c|c|c|c|c|c|c|c|}
\hline \multirow[b]{2}{*}{ Site } & \multirow[b]{2}{*}{ Date } & \multicolumn{2}{|c|}{ Aluminum } & \multicolumn{2}{|c|}{ Iron } & \multicolumn{2}{|c|}{ Copper } & \multicolumn{2}{|c|}{ Cadmlum } & \multicolumn{2}{|c|}{ Manganese } & \multicolumn{2}{|c|}{ Znc } \\
\hline & & Load & $\begin{array}{l}\text { Standard } \\
\text { error }\end{array}$ & Load & $\begin{array}{l}\text { Standard } \\
\text { error }\end{array}$ & Load & $\begin{array}{c}\text { Standard } \\
\text { error }\end{array}$ & Load & $\begin{array}{l}\text { Standard } \\
\text { error }\end{array}$ & Load & $\begin{array}{l}\text { Standard } \\
\text { error }\end{array}$ & Load & $\begin{array}{l}\text { Standard } \\
\text { error }\end{array}$ \\
\hline$\overline{\text { AR34.5 }}$ & $04 / 29 / 94$ & 1,230 & 160 & 2,600 & 298 & 57 & 5.8 & $<0.3$ & $<0.1$ & 170 & 12 & 39 & $\overline{4.1}$ \\
\hline AR31.0 & $04 / 29 / 94$ & 137 & 48 & 343 & 104 & 26 & 1.9 & 0.3 & $<0.1$ & 229 & 8.9 & 57 & 9.4 \\
\hline AR34.5 & $04 / 30 / 94$ & 1,080 & 140 & 2,270 & 261 & 50 & 5.0 & $<0.2$ & $<0.1$ & 149 & 10 & 34 & 3.6 \\
\hline AR31.0 & $04 / 30 / 94$ & 137 & 48 & 343 & 104 & 26 & 1.9 & 0.3 & $<0.1$ & 229 & 8.9 & 57 & 9.4 \\
\hline AR34.5 & $05 / 01 / 94$ & 1,110 & 145 & 2,350 & 269 & 51 & 5.2 & $<0.3$ & $<0.1$ & 154 & 10 & 35 & 3.7 \\
\hline AR31.0 & $05 / 01 / 94$ & 137 & 48 & 343 & 104 & 26 & 1.9 & 0.3 & $<0.1$ & 229 & 8.9 & 57 & 9.4 \\
\hline AR34.5 & $05 / 02 / 94$ & 1,020 & 132 & 2,150 & 246 & 47 & 4.8 & $<0.2$ & $<0.1$ & 142 & 9.6 & 32 & 3.4 \\
\hline AR31.0 & $05 / 02 / 94$ & 148 & 52 & 372 & 113 & 28 & 2.1 & 0.4 & $<0.1$ & 249 & 9.6 & 62 & 10 \\
\hline AR34.5 & $05 / 03 / 94$ & 982 & 128 & 2,070 & 238 & 45 & 4.6 & $<0.2$ & $<0.1$ & 136 & 9.2 & 31 & 3.3 \\
\hline AR31.0 & $05 / 03 / 94$ & 157 & 55 & 394 & 120 & 30 & 2.2 & 0.4 & $<0.1$ & 264 & 10 & 66 & 11 \\
\hline AR34.5 & $05 / 04 / 94$ & 1,060 & 138 & 2,250 & 258 & 49 & 5.0 & $<0.2$ & $<0.1$ & 147 & 10 & 34 & 3.6 \\
\hline AR31.0 & $05 / 04 / 94$ & 157 & 55 & 394 & 120 & 30 & 2.2 & 0.4 & $<0.1$ & 264 & 10 & 66 & 11 \\
\hline AR34.5 & $05 / 05 / 94$ & 1,730 & 225 & 3,640 & 418 & 80 & 8.1 & $<0.4$ & $<0.1$ & 239 & 16 & 55 & 5.8 \\
\hline AR31.0 & $05 / 05 / 94$ & 200 & 70 & 501 & 152 & 38 & 2.8 & 0.5 & $<0.1$ & 335 & 13 & 83 & 14 \\
\hline AR34.5 & $05 / 06 / 94$ & 2,860 & 372 & 6,040 & 693 & 132 & 13 & $<0.7$ & $<0.1$ & 396 & 27 & 91 & 9.6 \\
\hline AR31.0 & $05 / 06 / 94$ & 311 & 108 & 779 & 237 & 59 & 4.4 & 0.7 & $<0.1$ & 521 & 20 & 130 & 21 \\
\hline AR34.5 & $05 / 07 / 94$ & 3,630 & 472 & 7,660 & 880 & 168 & 17 & $<0.8$ & $<0.1$ & 503 & 34 & 115 & 12 \\
\hline AR31.0 & $05 / 07 / 94$ & 364 & 127 & 912 & 277 & 69 & 5.1 & 0.9 & 0.1 & 610 & 24 & 152 & 25 \\
\hline AR34.5 & $05 / 08 / 94$ & 3,610 & 469 & 7,610 & 874 & 167 & 17 & $<0.8$ & $<0.1$ & 499 & 34 & 114 & 12 \\
\hline AR31.0 & $05 / 08 / 94$ & 400 & 139 & 1,000 & 305 & 76 & 5.6 & 0.9 & 0.1 & 670 & 26 & 167 & 28 \\
\hline AR34.5 & $05 / 09 / 94$ & 4,100 & 534 & 8,660 & 994 & 190 & 19 & $<0.9$ & $<0.1$ & 568 & 39 & 130 & 14 \\
\hline AR31.0 & $05 / 09 / 94$ & 502 & 175 & 1,260 & 383 & 95 & 7.0 & 1.2 & 0.1 & 841 & 32 & 209 & 34 \\
\hline AR34.5 & $05 / 10 / 94$ & 3,060 & 398 & 6,470 & 742 & 142 & 14 & $<0.7$ & $<0.1$ & 424 & 29 & 97 & 10 \\
\hline AR31.0 & $05 / 10 / 94$ & 498 & 174 & 1,250 & 380 & 94 & 7.0 & 1.2 & 0.1 & 834 & 32 & 208 & 34 \\
\hline AR34.5 & $05 / 11 / 94$ & 2,830 & 368 & 5,970 & 685 & 131 & 13 & $<0.6$ & $<0.1$ & 391 & 27 & 90 & 9.5 \\
\hline AR31.0 & $05 / 11 / 94$ & 395 & 138 & 990 & 301 & 75 & 5.5 & 0.9 & 0.1 & 661 & 26 & 164 & 27 \\
\hline AR34.5 & $05 / 12 / 94$ & 3,890 & 506 & 8,210 & 943 & 180 & 18 & $<0.9$ & $<0.1$ & 539 & 37 & 123 & 13 \\
\hline AR31.0 & $05 / 12 / 94$ & 354 & 123 & 886 & 270 & 67 & 4.9 & 0.8 & $<0.1$ & 592 & 23 & 147 & 24 \\
\hline AR34.5 & $05 / 13 / 94$ & 5,120 & 666 & 10,800 & 1,240 & 237 & 24 & $<1.2$ & $<0.1$ & 709 & 48 & 162 & 17 \\
\hline AR31.0 & $05 / 13 / 94$ & 2,210 & 183 & 4,400 & 369 & 126 & 11 & 1.1 & 0.1 & 549 & 27 & 163 & 1.3 \\
\hline AR34.5 & $05 / 14 / 94$ & 5,810 & 755 & 12,300 & 1,410 & 268 & 27 & $<1.3$ & $<0.1$ & 804 & 55 & 184 & 20 \\
\hline AR31.0 & $05 / 14 / 94$ & 2,810 & 233 & 5,610 & 470 & 160 & 14 & 1.4 & 0.2 & 700 & 34 & 208 & 1.7 \\
\hline AR34.5 & $05 / 15 / 94$ & 6,400 & 832 & 13,500 & 1,550 & 296 & 30 & $<1.5$ & $<0.1$ & 886 & 60 & 202 & 22 \\
\hline AR31.0 & $05 / 15 / 94$ & 3,410 & 283 & 6,810 & 570 & 195 & 17 & 1.6 & 0.2 & 849 & 42 & 253 & 2.1 \\
\hline AR34.5 & $05 / 16 / 94$ & 6,790 & 883 & 14,300 & 1,645 & 314 & 32 & $<1.5$ & $<0.1$ & 940 & 64 & 215 & 23 \\
\hline AR31.0 & $05 / 16 / 94$ & 3,680 & 304 & 7,340 & 615 & 210 & 18 & 1.8 & 0.2 & 915 & 45 & 272 & 2.2 \\
\hline AR34.5 & $05 / 17 / 94$ & 7,720 & 1,000 & 16,300 & 1,870 & 357 & 36 & $<1.8$ & $<0.1$ & 1,070 & 73 & 244 & 26 \\
\hline AR31.0 & $05 / 17 / 94$ & 4,000 & 330 & 7,960 & 668 & 228 & 20 & 1.9 & 0.3 & 993 & 49 & 296 & 2.4 \\
\hline AR34.5 & $05 / 18 / 94$ & 8,020 & 1,040 & 16,900 & 1,940 & 371 & 38 & $<1.8$ & $<0.1$ & 1,110 & 76 & 254 & 27 \\
\hline AR31.0 & $05 / 18 / 94$ & 4,220 & 349 & 8,420 & 705 & 241 & 21 & 2.0 & 0.3 & 1,050 & 51 & 312 & 2.5 \\
\hline AR34.5 & $05 / 19 / 94$ & 8,610 & 1,120 & 18,200 & 2,090 & 398 & 40 & $<2.0$ & $<0.1$ & 1,190 & 81 & 272 & 29 \\
\hline AR31.0 & $05 / 19 / 94$ & 4,230 & 350 & 8,440 & 707 & 241 & 21 & 2.0 & 0.3 & 1,050 & 52 & 314 & 2.6 \\
\hline
\end{tabular}


Table 7. Estimated daily total-metal loads and standard errors for sites AR34.5 and AR31.0, April 1994 through March 1995-Continued

[Loads and standard errors are in pounds per day; $<$, less than;,-- no data]

\begin{tabular}{|c|c|c|c|c|c|c|c|c|c|c|c|c|c|}
\hline \multirow[b]{2}{*}{ Site } & \multirow[b]{2}{*}{ Date } & \multicolumn{2}{|c|}{ Aluminum } & \multicolumn{2}{|c|}{ Iron } & \multicolumn{2}{|c|}{ Copper } & \multicolumn{2}{|c|}{ Cadmlum } & \multicolumn{2}{|c|}{ Manganese } & \multicolumn{2}{|c|}{ Zlnc } \\
\hline & & Load & $\begin{array}{l}\text { Standard } \\
\text { error }\end{array}$ & Load & $\begin{array}{l}\text { Standard } \\
\text { error }\end{array}$ & Load & $\begin{array}{l}\text { Standard } \\
\text { error }\end{array}$ & Load & $\begin{array}{l}\text { Standard } \\
\text { error }\end{array}$ & Load & $\begin{array}{c}\text { Standard } \\
\text { orror }\end{array}$ & Load & $\begin{array}{l}\text { Standard } \\
\text { error }\end{array}$ \\
\hline$\overline{\text { AR34.5 }}$ & $05 / 20 / 94$ & 8,660 & 1,120 & 18,300 & 2,100 & 400 & 41 & $<2.0$ & $<0.1$ & 1,200 & 82 & 274 & 29 \\
\hline AR31.0 & $05 / 20 / 94$ & 4,240 & 351 & 8,450 & 708 & 242 & 21 & 2.0 & 0.3 & 1,050 & 52 & 314 & 2.6 \\
\hline AR34.5 & $05 / 21 / 94$ & 8,240 & 1,072 & 17,400 & 2,000 & 381 & 39 & $<1.9$ & $<0.1$ & 1,140 & 78 & 261 & 28 \\
\hline AR31.0 & $05 / 21 / 94$ & 4,230 & 350 & 8,440 & 707 & 241 & 21 & 2.0 & 0.3 & 1,050 & 52 & 314 & 2.6 \\
\hline AR34.5 & $05 / 22 / 94$ & 14,300 & -- & 28,800 & -- & 1,040 & -- & $<2.7$ & -- & 1,280 & -- & 452 & -- \\
\hline AR31.0 & $05 / 22 / 94$ & 4,250 & 352 & 8,480 & 711 & 242 & 21 & 2.0 & 0.3 & 1,060 & 52 & 315 & 2.6 \\
\hline AR34.5 & $05 / 23 / 94$ & 15,300 & -- & 30,900 & -- & 1,120 & -- & $<2.9$ & -- & 1,370 & -- & 486 & -- \\
\hline AR31.0 & $05 / 23 / 94$ & 4,720 & 390 & 9,410 & 788 & 269 & 23 & 2.3 & 0.3 & 1,170 & 57 & 349 & 2.8 \\
\hline AR34.5 & $05 / 24 / 94$ & 14,200 & -- & 28,600 & -- & 1,040 & -- & $<2.7$ & -- & 1,270 & -- & 450 & -- \\
\hline AR31.0 & $05 / 24 / 94$ & 5,030 & 417 & 10,000 & 841 & 287 & 25 & 2.4 & 0.3 & 1,250 & 61 & 373 & 3.0 \\
\hline AR34.5 & $05 / 25 / 94$ & 12,100 & -- & 24,400 & -- & 886 & -- & $<2.3$ & -- & 1,080 & -- & 383 & -- \\
\hline AR31.0 & $05 / 25 / 94$ & 5,030 & 417 & 10,000 & 841 & 287 & 25 & 2.4 & 0.3 & 1,250 & 61 & 373 & 3.0 \\
\hline AR34.5 & $05 / 26 / 94$ & 10,800 & 2,900 & 25,700 & 8,380 & 1,180 & 142 & 2.5 & 0.1 & 1,120 & 170 & 381 & 15 \\
\hline AR31.0 & $05 / 26 / 94$ & 4,560 & 377 & 9,080 & 761 & 260 & 23 & 2.2 & 0.3 & 1,130 & 55 & 337 & 2.7 \\
\hline AR34.5 & $05 / 27 / 94$ & 9,580 & 2,570 & 22,800 & 7,450 & 1,050 & 126 & 2.3 & 0.1 & 998 & 151 & 338 & 14 \\
\hline AR31.0 & $05 / 27 / 94$ & 3,490 & 289 & 6,960 & 583 & 199 & 17 & 1.7 & 0.2 & 868 & 42 & 258 & 2.1 \\
\hline AR34.5 & $05 / 28 / 94$ & 11,100 & 2,990 & 26,500 & 8,640 & 1,220 & 146 & 2.6 & 0.1 & 1,160 & 175 & 393 & 16 \\
\hline AR31.0 & 05/28/94 & 2,120 & -- & 4,720 & -- & 329 & - & 1.5 & -- & 824 & -- & 268 & -- \\
\hline AR34.5 & $05 / 29 / 94$ & 14,600 & 3,920 & 34,700 & 11,300 & 1,600 & 192 & 3.4 & 0.1 & 1,520 & 230 & 516 & 21 \\
\hline AR31.0 & $05 / 29 / 94$ & 2,120 & -- & 4,720 & -- & 329 & - & 1.5 & - & 824 & -- & 268 & -- \\
\hline AR34.5 & $05 / 30 / 94$ & 18,500 & 4,970 & 44,000 & 14,400 & 2,030 & 244 & 4.4 & 0.1 & 1,930 & 291 & 653 & 26 \\
\hline AR31.0 & $05 / 30 / 94$ & 3,000 & -- & 6,690 & -- & 467 & -- & 2.2 & - & 1,170 & -- & 380 & -- \\
\hline AR34.5 & $05 / 31 / 94$ & 19,700 & 5,280 & 46,800 & 15,300 & 2,160 & 259 & 4.6 & 0.1 & 2,050 & 309 & 694 & 28 \\
\hline AR31.0 & $05 / 31 / 94$ & 4,010 & -- & 8,930 & -- & 623 & $-\cdot$ & 2.9 & - & 1,560 & - & 507 & -- \\
\hline AR34.5 & $06 / 01 / 94$ & 21,400 & 5,740 & 50,800 & 16,600 & 2,340 & 282 & 5.0 & 0.2 & 2,230 & 336 & 754 & 30 \\
\hline AR31.0 & $06 / 01 / 94$ & 4,040 & -- & 9,000 & -- & 628 & -- & 2.9 & - & 1,570 & -- & 511 & -- \\
\hline AR34.5 & $06 / 02 / 94$ & 20,900 & 5,610 & 49,600 & 16,200 & 2,290 & 275 & 4.9 & 0.2 & 2,170 & 328 & 737 & 30 \\
\hline AR31.0 & $06 / 02 / 94$ & 3,530 & -- & 7,880 & -- & 549 & -- & 2.6 & - & 1,380 & -- & 447 & -- \\
\hline AR34.5 & $06 / 03 / 94$ & 19,000 & 5,100 & 45,100 & 14,700 & 2,080 & 250 & 4.5 & 0.1 & 1,980 & 299 & 670 & 27 \\
\hline AR31.0 & $06 / 03 / 94$ & 3,280 & -- & 7,320 & -- & 510 & -- & 2.4 & -- & 1,280 & -- & 415 & -- \\
\hline AR34.5 & $06 / 04 / 94$ & 19,800 & 5,330 & 47,200 & 15,400 & 2,170 & 261 & 4.7 & 0.2 & 2,070 & 312 & 700 & 28 \\
\hline AR31.0 & $06 / 04 / 94$ & 3,150 & -- & 7,020 & - & 490 & -- & 2.3 & -- & 1,230 & -- & 398 & -- \\
\hline AR34.5 & $06 / 05 / 94$ & 17,800 & 4,780 & 42,300 & 13,800 & 1,950 & 234 & 4.2 & 0.1 & 1,850 & 280 & 628 & 25 \\
\hline AR31.0 & $06 / 05 / 94$ & 1,910 & -- & 5,580 & -- & 1,120 & -- & 4.4 & - & 1,320 & -- & 574 & -- \\
\hline AR34.5 & $06 / 06 / 94$ & 16,000 & 4,290 & 38,000 & 12,400 & 1,750 & 210 & 3.8 & 0.1 & 1,660 & 251 & 564 & 23 \\
\hline AR31.0 & $06 / 06 / 94$ & 1,830 & -- & 5,360 & -- & 1,070 & -- & 4.2 & -- & 1,270 & -- & 551 & -- \\
\hline AR34.5 & $06 / 07 / 94$ & 14,400 & 3,860 & 34,200 & 11,200 & 1,580 & 190 & 3.4 & 0.1 & 1,500 & 226 & 508 & 20 \\
\hline AR31.0 & $06 / 07 / 94$ & 1,510 & - & 4,410 & -- & 883 & -- & 3.5 & - & 1,040 & -- & 454 & - \\
\hline AR34.5 & $06 / 08 / 94$ & 7,360 & 591 & 16,700 & 996 & 3,770 & 391 & 6.5 & 0.7 & 1,510 & 146 & 943 & 90 \\
\hline AR31.0 & $06 / 08 / 94$ & 1,290 & -- & 3,770 & -- & 755 & - & 3.0 & -- & 892 & -- & 388 & -- \\
\hline AR34.5 & $06 / 09 / 94$ & 7,010 & 562 & 15,900 & 948 & 3,590 & 372 & 6.2 & 0.7 & 1,440 & 139 & 898 & 86 \\
\hline AR31.0 & 06/09/94 & 1,230 & -- & 3,610 & -- & 721 & -- & 2.8 & - & 853 & -- & 371 & -- \\
\hline
\end{tabular}


Table 7. Estimated daily total-metal loads and standard errors for sites AR34.5 and AR31.0, April 1994 through March 1995-Continued

[Loads and standard errors are in pounds per day; <, less than; --, no data]

\begin{tabular}{|c|c|c|c|c|c|c|c|c|c|c|c|c|c|}
\hline \multirow[b]{2}{*}{ Site } & \multirow[b]{2}{*}{ Date } & \multicolumn{2}{|c|}{ Aluminum } & \multicolumn{2}{|c|}{ Iron } & \multicolumn{2}{|c|}{ Copper } & \multicolumn{2}{|c|}{ Cadmlum } & \multicolumn{2}{|c|}{ Manganese } & \multicolumn{2}{|c|}{ ZInc } \\
\hline & & Load & $\begin{array}{c}\text { Standard } \\
\text { error }\end{array}$ & Load & $\begin{array}{l}\text { Standard } \\
\text { error }\end{array}$ & Load & $\begin{array}{l}\text { Standard } \\
\text { error }\end{array}$ & Load & $\begin{array}{l}\text { Standard } \\
\text { error }\end{array}$ & Load & $\begin{array}{l}\text { Standard } \\
\text { error }\end{array}$ & Load & $\begin{array}{l}\text { Standard } \\
\text { error }\end{array}$ \\
\hline$\overline{\text { AR34.5 }}$ & $06 / 10 / 94$ & 6,820 & 547 & 15,500 & 923 & 3,490 & 362 & 6.0 & 0.7 & 1,400 & 135 & 874 & 84 \\
\hline AR31.0 & $06 / 10 / 94$ & 1,230 & - & 3,610 & -- & 721 & -- & 2.8 & - & 853 & -- & 371 & - \\
\hline AR34.5 & $06 / 11 / 94$ & 6,290 & 504 & 14,300 & 850 & 3,220 & 333 & 5.5 & 0.6 & 1,290 & 124 & 805 & 77 \\
\hline AR31.0 & $06 / 11 / 94$ & 692 & 70 & 4,530 & 490 & 1,670 & 131 & 3.9 & 0.1 & 966 & 32 & 557 & 53 \\
\hline AR34.5 & $06 / 12 / 94$ & 5,600 & 449 & 12,700 & 757 & 2,860 & 297 & 4.9 & 0.6 & 1,150 & 111 & 717 & 69 \\
\hline AR31.0 & $06 / 12 / 94$ & 692 & 70 & 4,530 & 490 & 1,670 & 131 & 3.9 & 0.1 & 966 & 32 & 557 & 53 \\
\hline AR34.5 & $06 / 13 / 94$ & 5,850 & 469 & 13,300 & 791 & 2,990 & 310 & 5.1 & 0.6 & 1,200 & 116 & 750 & 72 \\
\hline AR31.0 & $06 / 13 / 94$ & 692 & 70 & 4,530 & 490 & 1,670 & 131 & 3.9 & 0.1 & 966 & 32 & 557 & 53 \\
\hline AR34.5 & $06 / 14 / 94$ & 5,800 & 465 & 13,200 & 784 & 2,970 & 308 & 5.1 & 0.6 & 1,190 & 115 & 743 & 71 \\
\hline AR31.0 & $06 / 14 / 94$ & 692 & 70 & 4,530 & 490 & 1,670 & 131 & 3.9 & 0.1 & 966 & 32 & 557 & 53 \\
\hline AR34.5 & $06 / 15 / 94$ & 5,180 & 415 & 11,800 & 700 & 2,650 & 275 & 4.6 & 0.5 & 1,060 & 102 & 663 & 64 \\
\hline AR31.0 & $06 / 15 / 94$ & 692 & 70 & 4,530 & 490 & 1,670 & 131 & 3.9 & 0.1 & 966 & 32 & 557 & 53 \\
\hline AR34.5 & $06 / 16 / 94$ & 4,570 & 367 & 10,400 & 618 & 2,340 & 242 & 4.0 & 0.5 & 940 & 90 & 586 & 56 \\
\hline AR31.0 & $06 / 16 / 94$ & 637 & 64 & 4,170 & 451 & 1,530 & 120 & 3.6 & 0.1 & 889 & 29 & 513 & 49 \\
\hline AR34.5 & $06 / 17 / 94$ & 4,220 & 339 & 9,600 & 571 & 2,160 & 224 & 3.7 & 0.4 & 868 & 84 & 541 & 52 \\
\hline AR31.0 & $06 / 17 / 94$ & 571 & 58 & 3,740 & 404 & 1,370 & 108 & 3.2 & 0.1 & 796 & 26 & 459 & 44 \\
\hline AR34.5 & $06 / 18 / 94$ & 3,950 & 317 & 8,990 & 534 & 2,020 & 210 & 3.5 & 0.4 & 812 & 78 & 506 & 48 \\
\hline AR31.0 & $06 / 18 / 94$ & 497 & 50 & 3,250 & 351 & 1,200 & 94 & 2.8 & 0.1 & 693 & 23 & 400 & 38 \\
\hline AR34.5 & $06 / 19 / 94$ & 2,590 & - & 5,620 & -- & 699 & -- & 2.2 & -- & 475 & -- & 263 & - \\
\hline AR31.0 & $06 / 19 / 94$ & 407 & 41 & 2,660 & 288 & 980 & 77 & 2.3 & 0.1 & 568 & 19 & 328 & 31 \\
\hline AR34.5 & $06 / 20 / 94$ & 4,330 & - & 9,420 & -- & 1,170 & -- & 3.7 & -- & 796 & - & 441 & -- \\
\hline AR31.0 & $06 / 20 / 94$ & 368 & 37 & 2,410 & 260 & 886 & 70 & 2.1 & 0.1 & 513 & 17 & 296 & 28 \\
\hline AR34.5 & $06 / 21 / 94$ & 3,950 & -- & 8,580 & -- & 1,070 & -- & 3.3 & -- & 725 & -- & 402 & -- \\
\hline AR31.0 & $06 / 21 / 94$ & 504 & 51 & 3,300 & 356 & 1,210 & 95 & 2.8 & 0.1 & 703 & 23 & 406 & 38 \\
\hline AR34.5 & $06 / 22 / 94$ & 4,800 & - & 10,400 & -- & 1,300 & -- & 4.0 & -- & 881 & -- & 488 & -- \\
\hline AR31.0 & $06 / 22 / 94$ & 591 & 60 & 3,870 & 418 & 1,420 & 112 & 3.3 & 0.1 & 825 & 27 & 476 & 45 \\
\hline AR34.5 & $06 / 23 / 94$ & 3,280 & - & 7,120 & -- & 886 & - & 2.8 & -- & 602 & -- & 333 & -- \\
\hline AR31.0 & $06 / 23 / 94$ & 543 & 55 & 3,560 & 384 & 1,310 & 103 & 3.0 & 0.1 & 758 & 25 & 437 & 42 \\
\hline AR34.5 & $06 / 24 / 94$ & 4,180 & 335 & 9,510 & 565 & 2,140 & 222 & 3.7 & 0.4 & 860 & 83 & 536 & 51 \\
\hline AR31.0 & $06 / 24 / 94$ & 446 & 45 & 2,920 & 315 & 1,070 & 84 & 2.5 & 0.1 & 622 & 20 & 359 & 34 \\
\hline AR34.5 & $06 / 25 / 94$ & 3,640 & 292 & 8,280 & 492 & 1,860 & 193 & 3.2 & 0.4 & 749 & 72 & 466 & 45 \\
\hline AR31.0 & $06 / 25 / 94$ & 375 & 38 & 2,460 & 265 & 903 & 71 & 2.1 & 0.1 & 524 & 17 & 302 & 29 \\
\hline AR34.5 & $06 / 26 / 94$ & 3,250 & 261 & 7,390 & 440 & 1,660 & 172 & 2.9 & 0.3 & 668 & 64 & 416 & 40 \\
\hline AR31.0 & $06 / 26 / 94$ & 359 & 36 & 2,350 & 254 & 865 & 68 & 2.0 & 0.1 & 501 & 16 & 289 & 28 \\
\hline AR34.5 & $06 / 27 / 94$ & 2,850 & 228 & 6,470 & 385 & 1,460 & 151 & 2.5 & 0.3 & 585 & 56 & 364 & 35 \\
\hline AR31.0 & $06 / 27 / 94$ & 359 & 36 & 2,350 & 254 & 865 & 68 & 2.0 & 0.1 & 501 & 16 & 289 & 28 \\
\hline AR34.5 & $06 / 28 / 94$ & 2,520 & 202 & 5,740 & 341 & 1,290 & 134 & 2.2 & 0.3 & 519 & 50 & 323 & 31 \\
\hline AR31.0 & $06 / 28 / 94$ & 359 & 36 & 2,350 & 254 & 865 & 68 & 2.0 & 0.1 & 501 & 16 & 289 & 28 \\
\hline AR34.5 & $06 / 29 / 94$ & 219 & 176 & 5,000 & 297 & 1,120 & 117 & 1.9 & 0.2 & 452 & 44 & 282 & 27 \\
\hline AR31.0 & $06 / 29 / 94$ & 358 & 36 & 2,340 & 253 & 861 & 68 & 2.0 & 0.1 & 499 & 16 & 288 & 27 \\
\hline AR34.5 & $06 / 30 / 94$ & 1,970 & 158 & 4,480 & 266 & 1,010 & 104 & 1.7 & 0.2 & 405 & 39 & 252 & 24 \\
\hline AR31.0 & $06 / 30 / 94$ & 329 & 33 & 2,150 & 232 & 792 & 62 & 1.8 & 0.1 & 459 & 15 & 265 & 25 \\
\hline
\end{tabular}


Table 7. Estimated daily total-metal loads and standard errors for sites AR34.5 and AR31.0, April 1994 through March 1995-Continued

[Loads and standard errors are in pounds per day; <, less than; --, no data]

\begin{tabular}{|c|c|c|c|c|c|c|c|c|c|c|c|c|c|}
\hline \multirow[b]{2}{*}{ Site } & \multirow[b]{2}{*}{ Date } & \multicolumn{2}{|c|}{ Aluminum } & \multicolumn{2}{|c|}{ Iron } & \multicolumn{2}{|c|}{ Copper } & \multicolumn{2}{|c|}{ Cadmium } & \multicolumn{2}{|c|}{ Manganese } & \multicolumn{2}{|c|}{ ZInc } \\
\hline & & Load & $\begin{array}{l}\text { Standard } \\
\text { error }\end{array}$ & Load & $\begin{array}{l}\text { Standard } \\
\text { error }\end{array}$ & Load & $\begin{array}{l}\text { Standard } \\
\text { error }\end{array}$ & Load & $\begin{array}{l}\text { Standard } \\
\text { error }\end{array}$ & Load & $\begin{array}{l}\text { Standard } \\
\text { error }\end{array}$ & Load & $\begin{array}{l}\text { Standard } \\
\text { error }\end{array}$ \\
\hline$\overline{\mathrm{AR} 34.5}$ & $07 / 01 / 94$ & 1,780 & 143 & 4,050 & 241 & 911 & 94 & 1.6 & $\overline{0.2}$ & 366 & 35 & 228 & 22 \\
\hline AR31.0 & $07 / 01 / 94$ & 307 & 31 & 2,010 & 217 & 739 & 58 & 1.7 & 0.1 & 428 & 14 & 247 & 24 \\
\hline AR34.5 & $07 / 02 / 94$ & 1,700 & 136 & 3,860 & 230 & 869 & 90 & 1.5 & 0.2 & 349 & 34 & 218 & 21 \\
\hline AR31.0 & $07 / 02 / 94$ & 307 & 31 & 2,010 & 217 & 739 & 58 & 1.7 & 0.1 & 428 & 14 & 247 & 24 \\
\hline AR34.5 & $07 / 03 / 94$ & 1,520 & 122 & 3,460 & 206 & 780 & 81 & 1.3 & 0.2 & 313 & 30 & 195 & 19 \\
\hline AR31.0 & $07 / 03 / 94$ & 306 & 31 & 2,000 & 216 & 736 & 58 & 1.7 & 0.1 & 426 & 14 & 246 & 23 \\
\hline AR34.5 & $07 / 04 / 94$ & 1,430 & 115 & 3,250 & 193 & 731 & 76 & 1.3 & 0.1 & 294 & 28 & 183 & 18 \\
\hline AR31.0 & $07 / 04 / 94$ & 284 & 29 & 1,860 & 201 & 684 & 54 & 1.6 & 0.1 & 396 & 13 & 228 & 22 \\
\hline AR34.5 & $07 / 05 / 94$ & 1,240 & 100 & 2,820 & 168 & 635 & 66 & 1.1 & 0.1 & 255 & 24 & 159 & 15 \\
\hline AR31.0 & $07 / 05 / 94$ & 271 & 27 & 1,770 & 192 & 652 & 51 & 1.5 & 0.1 & 378 & 12 & 218 & 21 \\
\hline AR34.5 & $07 / 06 / 94$ & 1,130 & 91 & 2,580 & 153 & 580 & 60 & 1.0 & 0.1 & 233 & 22 & 145 & 14 \\
\hline AR31.0 & $07 / 06 / 94$ & 271 & 27 & 1,770 & 192 & 652 & 51 & 1.5 & 0.1 & 378 & 12 & 218 & 21 \\
\hline AR34.5 & $07 / 07 / 94$ & 1,080 & 86 & 2,450 & 146 & 552 & 57 & 0.9 & 0.1 & 222 & 21 & 138 & 13 \\
\hline AR31.0 & $07 / 07 / 94$ & 271 & 27 & 1,770 & 192 & 652 & 51 & 1.5 & 0.1 & 378 & 12 & 218 & 21 \\
\hline AR34.5 & $07 / 08 / 94$ & 971 & 78 & 2,210 & 131 & 497 & 52 & 0.9 & 0.1 & 200 & 19 & 124 & 12 \\
\hline AR31.0 & $07 / 08 / 94$ & 269 & 27 & 1,760 & 190 & 649 & 51 & 1.5 & 0.1 & 376 & 12 & 217 & 21 \\
\hline AR34.5 & $07 / 09 / 94$ & 944 & 76 & 2,150 & 128 & 483 & 50 & 0.8 & 0.1 & 194 & 19 & 121 & 12 \\
\hline AR31.0 & $07 / 09 / 94$ & 264 & 27 & 1,730 & 186 & 635 & 50 & 1.5 & 0.1 & 368 & 12 & 212 & 20 \\
\hline AR34.5 & $07 / 10 / 94$ & 877 & 70 & 1,990 & 118 & 448 & 46 & 0.8 & 0.1 & 180 & 17 & 112 & 11 \\
\hline AR31.0 & $07 / 10 / 94$ & 239 & 24 & 1,560 & 169 & 575 & 45 & 1.3 & 0.1 & 334 & 11 & 192 & 18 \\
\hline AR34.5 & $07 / 11 / 94$ & 836 & 67 & 1,900 & 113 & 428 & 44 & 0.7 & 0.1 & 172 & 16 & 107 & 10 \\
\hline AR31.0 & $07 / 11 / 94$ & 351 & 17 & 996 & 96 & 604 & 23 & 1.6 & $<0.1$ & 475 & 20 & 205 & 1.3 \\
\hline AR34.5 & $07 / 12 / 94$ & 796 & 64 & 1,810 & 108 & 407 & 42 & 0.7 & 0.1 & 164 & 16 & 102 & 9.8 \\
\hline AR31.0 & $07 / 12 / 94$ & 324 & 16 & 920 & 88 & 558 & 21 & 1.5 & $<0.1$ & 438 & 19 & 190 & 1.2 \\
\hline AR34.5 & $07 / 13 / 94$ & 769 & 62 & 1,750 & 104 & 393 & 41 & 0.7 & 0.1 & 158 & 15 & 98 & 9.4 \\
\hline AR31.0 & $07 / 13 / 94$ & 324 & 16 & 920 & 88 & 558 & 21 & 1.5 & $<0.1$ & 438 & 19 & 190 & 1.2 \\
\hline AR34.5 & $07 / 14 / 94$ & 701 & 56 & 1,590 & 95 & 359 & 37 & 0.6 & 0.1 & 144 & 14 & 90 & 8.6 \\
\hline AR31.0 & $07 / 14 / 94$ & 322 & 16 & 913 & 88 & 553 & 21 & 1.4 & $<0.1$ & 435 & 19 & 188 & 1.2 \\
\hline AR34.5 & $07 / 15 / 94$ & 688 & 55 & 1,560 & 93 & 352 & 36 & 0.6 & 0.1 & 141 & 14 & 88 & 8.4 \\
\hline AR31.0 & $07 / 15 / 94$ & 315 & 16 & 892 & 86 & 541 & 20 & 1.4 & $<0.1$ & 425 & 18 & 184 & 1.2 \\
\hline AR34.5 & $07 / 16 / 94$ & 661 & 53 & 1,500 & 89 & 338 & 35 & 0.6 & 0.1 & 136 & 13 & 85 & 8.1 \\
\hline AR31.0 & $07 / 16 / 94$ & 312 & 15 & 885 & 85 & 536 & 20 & 1.4 & $<0.1$ & 422 & 18 & 183 & 1.1 \\
\hline AR34.5 & $07 / 17 / 94$ & 607 & 49 & 1,380 & 82 & 310 & 32 & 0.5 & 0.1 & 125 & 12 & 78 & 7.5 \\
\hline AR31.0 & $07 / 17 / 94$ & 307 & 15 & 872 & 84 & 528 & 20 & 1.4 & $<0.1$ & 415 & 18 & 180 & 1.1 \\
\hline AR34.5 & $07 / 18 / 94$ & 566 & 45 & 1,290 & 77 & 290 & 30 & 0.5 & 0.1 & 116 & 11 & 73 & 7.0 \\
\hline AR31.0 & $07 / 18 / 94$ & 295 & 15 & 837 & 80 & 507 & 19 & 1.3 & $<0.1$ & 399 & 17 & 173 & 1.1 \\
\hline AR34.5 & 07/19/94 & 566 & 45 & 1,290 & 77 & 290 & 30 & 0.5 & 0.1 & 116 & 11 & 73 & 7.0 \\
\hline AR31.0 & $07 / 19 / 94$ & 281 & 14 & 796 & 76 & 482 & 18 & 1.3 & $<0.1$ & 379 & 16 & 164 & 1.0 \\
\hline AR34.5 & $07 / 20 / 94$ & 8,380 & -- & 15,700 & -- & 1,520 & -- & 2.3 & -- & 872 & - & 404 & -- \\
\hline AR31.0 & $07 / 20 / 94$ & 317 & 16 & 899 & 86 & 545 & 20 & 1.4 & $<0.1$ & 429 & 18 & 186 & 1.2 \\
\hline AR34.5 & $07 / 21 / 94$ & 798 & -- & 1,510 & - & 348 & -- & 0.9 & - & 209 & - & 95 & -- \\
\hline AR31.0 & $07 / 21 / 94$ & 334 & 16 & 948 & 91 & 574 & 22 & 1.5 & $<0.1$ & 452 & 19 & 195 & 1.2 \\
\hline
\end{tabular}


Table 7. Estimated daily total-metal loads and standard errors for sites AR34.5 and AR31.0, April 1994 through March 1995-Continued

[Loads and standard errors are in pounds per day; <, less than; --, no data]

\begin{tabular}{|c|c|c|c|c|c|c|c|c|c|c|c|c|c|}
\hline \multirow[b]{2}{*}{ Site } & \multirow[b]{2}{*}{ Date } & \multicolumn{2}{|c|}{ Aluminum } & \multicolumn{2}{|c|}{ Iron } & \multicolumn{2}{|c|}{ Copper } & \multicolumn{2}{|c|}{ Cadmlum } & \multicolumn{2}{|c|}{ Manganese } & \multicolumn{2}{|c|}{ Znc } \\
\hline & & Load & $\begin{array}{c}\text { Standard } \\
\text { error }\end{array}$ & Load & $\begin{array}{l}\text { Standard } \\
\text { error }\end{array}$ & Load & $\begin{array}{l}\text { Standard } \\
\text { error }\end{array}$ & Load & $\begin{array}{l}\text { Standard } \\
\text { error }\end{array}$ & Load & $\begin{array}{l}\text { Standard } \\
\text { error }\end{array}$ & Load & $\begin{array}{c}\text { Standard } \\
\text { error }\end{array}$ \\
\hline$\overline{\text { AR34.5 }}$ & $07 / 22 / 94$ & 814 & -- & 1,540 & - & 355 & -- & 0.9 & -- & 213 & -- & 97 & - \\
\hline AR31.0 & $07 / 22 / 94$ & 329 & 16 & 934 & 90 & 566 & 21 & 1.5 & $<0.1$ & 445 & 19 & 193 & 1.2 \\
\hline AR34.5 & $07 / 23 / 94$ & 654 & -- & 1,240 & -- & 285 & -- & 0.7 & -- & 172 & -- & 78 & -- \\
\hline AR31.0 & $07 / 23 / 94$ & 259 & 13 & 733 & 70 & 444 & 17 & 1.2 & $<0.1$ & 350 & 15 & 151 & 1.0 \\
\hline AR34.5 & $07 / 24 / 94$ & 670 & -- & 1,270 & -- & 292 & -- & 0.7 & -- & 176 & -- & 80 & -- \\
\hline AR31.0 & $07 / 24 / 94$ & 215 & 11 & 609 & 59 & 369 & 14 & 1.0 & $<0.1$ & 290 & 12 & 126 & 0.8 \\
\hline AR34.5 & $07 / 25 / 94$ & 893 & -- & 1,700 & -- & 389 & -- & 1.0 & -- & 234 & -. & 106 & - \\
\hline AR31.0 & $07 / 25 / 94$ & 217 & 11 & 616 & 59 & 373 & 14 & 1.0 & $<0.1$ & 293 & 13 & 127 & 0.8 \\
\hline AR34.5 & $07 / 26 / 94$ & 718 & -- & 1,360 & -- & 313 & -- & 0.8 & -- & 188 & -- & 85 & -- \\
\hline AR31.0 & $07 / 26 / 94$ & 217 & 11 & 616 & 59 & 373 & 14 & 1.0 & $<0.1$ & 293 & 13 & 127 & 0.8 \\
\hline AR34.5 & $07 / 27 / 94$ & 622 & -- & 1,180 & -- & 271 & -- & 0.7 & -- & 163 & -- & 74 & -- \\
\hline AR31.0 & $07 / 27 / 94$ & 217 & 11 & 616 & 59 & 373 & 14 & 1.0 & $<0.1$ & 293 & 13 & 127 & 0.8 \\
\hline AR34.5 & $07 / 28 / 94$ & 734 & -- & 1,390 & -- & 320 & -- & 0.8 & -- & 192 & -- & 87 & -- \\
\hline AR31.0 & $07 / 28 / 94$ & 217 & 11 & 616 & 59 & 373 & 14 & 1.0 & $<0.1$ & 293 & 13 & 127 & 0.8 \\
\hline AR34.5 & 07/29/94 & 830 & -- & 1,580 & -- & 362 & -- & 0.9 & -- & 218 & -- & 99 & -- \\
\hline AR31.0 & $07 / 29 / 94$ & 217 & 11 & 616 & 59 & 373 & 14 & 1.0 & $<0.1$ & 293 & 13 & 127 & 0.8 \\
\hline AR34.5 & $07 / 30 / 94$ & 734 & -- & 1,393 & -- & 320 & -- & 0.8 & -- & 192 & -- & 87 & - \\
\hline AR31.0 & $07 / 30 / 94$ & 215 & 11 & 609 & 59 & 369 & 14 & 1.0 & $<0.1$ & 290 & 12 & 126 & 0.8 \\
\hline AR34.5 & $07 / 31 / 94$ & 2,850 & 481 & 4,780 & 866 & 367 & 38 & 0.8 & 0.1 & 325 & 12 & 113 & 8.5 \\
\hline AR31.0 & $07 / 31 / 94$ & 215 & 11 & 609 & 59 & 369 & 14 & 1.0 & $<0.1$ & 290 & 12 & 126 & 0.8 \\
\hline AR34.5 & $08 / 01 / 94$ & 3,910 & 659 & 6,550 & 1,190 & 503 & 52 & 1.0 & 0.1 & 445 & 16 & 154 & 12 \\
\hline AR31.0 & $08 / 01 / 94$ & 242 & 12 & 685 & 66 & 415 & 16 & 1.1 & $<0.1$ & 326 & 14 & 141 & 0.9 \\
\hline AR34.5 & $08 / 02 / 94$ & 4,230 & 712 & 7,090 & 1,283 & 543 & 56 & 1.1 & 0.1 & 482 & 18 & 167 & 13 \\
\hline AR31.0 & 08/02/94 & 256 & 13 & 726 & 70 & 440 & 16 & 1.2 & $<0.1$ & 346 & 15 & 150 & 0.9 \\
\hline AR34.5 & $08 / 03 / 94$ & 900 & -- & 1,648 & -- & 364 & -- & 0.7 & -- & 240 & -- & 98 & -- \\
\hline AR31.0 & 08/03/94 & 254 & 13 & 719 & 69 & 436 & 16 & 1.1 & $<0.1$ & 343 & 15 & 148 & 0.9 \\
\hline AR34.5 & $08 / 04 / 94$ & 727 & -- & 1,330 & -- & 294 & -- & 0.6 & -- & 194 & -- & 80 & -- \\
\hline AR31.0 & $08 / 04 / 94$ & 254 & 13 & 719 & 69 & 436 & 16 & 1.1 & $<0.1$ & 343 & 15 & 148 & 0.9 \\
\hline AR34.5 & $08 / 05 / 94$ & 692 & -- & 1,270 & -- & 280 & -- & 0.5 & -- & 184 & -- & 76 & -- \\
\hline AR31.0 & $08 / 05 / 94$ & 195 & 9.7 & 553 & 53 & 335 & 12 & 0.9 & $<0.1$ & 264 & 11 & 114 & 0.7 \\
\hline AR34.5 & $08 / 06 / 94$ & 744 & -- & 1,360 & -- & 301 & -. & 0.6 & -- & 198 & -- & 81 & - \\
\hline AR31.0 & $08 / 06 / 94$ & 156 & 7.7 & 443 & 43 & 268 & 10 & 0.7 & $<0.1$ & 211 & 9.1 & 91 & 0.6 \\
\hline AR34.5 & 08/07/94 & 675 & -- & 1,240 & -- & 273 & -- & 0.5 & -- & 180 & -- & 74 & -- \\
\hline AR31.0 & 08/07/94 & 154 & 7.6 & 436 & 42 & 264 & 9.9 & 0.7 & $<0.1$ & 208 & 8.9 & 90 & 0.6 \\
\hline AR34.5 & $08 / 08 / 94$ & 588 & -- & 1,080 & - & 238 & -- & 0.5 & -- & 157 & -- & 64 & -- \\
\hline AR31.0 & $08 / 08 / 94$ & 144 & 7.1 & 408 & 39 & 247 & 9.3 & 0.6 & $<0.1$ & 194 & 8.4 & 84 & 0.5 \\
\hline AR34.5 & 08/09/94 & 554 & -- & 1,010 & -- & 224 & -- & 0.4 & -- & 148 & -- & 60 & -- \\
\hline AR31.0 & 08/09/94 & 132 & 6.5 & 374 & 36 & 226 & 8.5 & 0.6 & $<0.1$ & 178 & 7.7 & 77 & 0.5 \\
\hline AR34.5 & $08 / 10 / 94$ & 658 & - & 1,200 & -- & 266 & -- & 0.5 & -- & 175 & -- & 72 & -- \\
\hline AR31.0 & $08 / 10 / 94$ & 142 & 7.0 & 401 & 39 & 243 & 9.1 & 0.6 & $<0.1$ & 191 & 8.2 & 83 & 0.5 \\
\hline AR34.5 & $08 / 11 / 94$ & 2,760 & -. & 3,840 & -- & 413 & - & 0.8 & -. & 281 & - & 107 & -- \\
\hline AR31.0 & $08 / 11 / 94$ & 149 & 7.4 & 422 & 41 & 256 & 9.6 & 0.7 & $<0.1$ & 201 & 8.7 & 87 & 0.5 \\
\hline
\end{tabular}


Table 7. Estimated daily total-metal loads and standard errors for sites AR34.5 and AR31.0, April 1994 through March 1995-Continued

[Loads and standard errors are in pounds per day; $<$, less than; --, no data]

\begin{tabular}{|c|c|c|c|c|c|c|c|c|c|c|c|c|c|}
\hline \multirow[b]{2}{*}{ Site } & \multirow[b]{2}{*}{ Date } & \multicolumn{2}{|c|}{ Aluminum } & \multicolumn{2}{|c|}{ Iron } & \multicolumn{2}{|c|}{ Copper } & \multicolumn{2}{|c|}{ Cadmlum } & \multicolumn{2}{|c|}{ Manganese } & \multicolumn{2}{|c|}{ ZInc } \\
\hline & & Load & $\begin{array}{l}\text { Standard } \\
\text { error }\end{array}$ & Load & $\begin{array}{c}\text { Standard } \\
\text { error }\end{array}$ & Load & $\begin{array}{l}\text { Standard } \\
\text { error }\end{array}$ & Load & $\begin{array}{l}\text { Standard } \\
\text { error }\end{array}$ & Load & $\begin{array}{l}\text { Standard } \\
\text { error }\end{array}$ & Load & $\begin{array}{l}\text { Standard } \\
\text { error }\end{array}$ \\
\hline$\overline{\mathrm{AR} 34.5}$ & $08 / 12 / 94$ & 1,000 & - & 1,840 & - & 406 & -- & 0.8 & - & 267 & -- & 110 & - \\
\hline AR31.0 & $08 / 12 / 94$ & 217 & 21 & 910 & 28 & 294 & 8.3 & 0.7 & $<0.1$ & 336 & 10 & 108 & 3.6 \\
\hline AR34.5 & $08 / 13 / 94$ & 779 & - & 1,430 & -- & 315 & -- & 0.6 & -- & 207 & -- & 85 & -- \\
\hline AR31.0 & $08 / 13 / 94$ & 238 & 23 & 998 & 31 & 322 & 9.1 & 0.8 & $<0.1$ & 369 & 12 & 118 & 4.0 \\
\hline AR34.5 & $08 / 14 / 94$ & 11,400 & 6,620 & 25,700 & 18,700 & 406 & 206 & 0.9 & 0.3 & 674 & 215 & 167 & 76 \\
\hline AR31.0 & $08 / 14 / 94$ & 235 & 23 & 985 & 31 & 318 & 9.0 & 0.8 & $<0.1$ & 364 & 11 & 117 & 3.9 \\
\hline AR34.5 & $08 / 15 / 94$ & 16,300 & 9,480 & 36,900 & 26,900 & 583 & 295 & 1.3 & 0.5 & 966 & 308 & 239 & 108 \\
\hline AR31.0 & $08 / 15 / 94$ & 235 & 23 & 985 & 31 & 318 & 9.0 & 0.8 & $<0.1$ & 364 & 11 & 117 & 3.9 \\
\hline AR34.5 & $08 / 16 / 94$ & 1,520 & 343 & 3,350 & 983 & 306 & 6.7 & 0.8 & $<0.1$ & 319 & 20 & 105 & 6.0 \\
\hline AR31.0 & $08 / 16 / 94$ & 274 & 27 & 1,150 & 36 & 371 & 10 & 0.9 & 0.1 & 424 & 13 & 136 & 4.6 \\
\hline AR34.5 & $08 / 17 / 94$ & 1,200 & 271 & 2,650 & 778 & 242 & 5.3 & 0.6 & $<0.1$ & 252 & 16 & 83 & 4.7 \\
\hline AR31.0 & $08 / 17 / 94$ & 300 & 29 & 1,260 & 39 & 407 & 12 & 1.0 & 0.1 & 465 & 14 & 150 & 5.0 \\
\hline AR34.5 & $08 / 18 / 94$ & 976 & 220 & 2,150 & 631 & 197 & 4.3 & 0.5 & $<0.1$ & 205 & 13 & 68 & 3.8 \\
\hline AR31.0 & $08 / 18 / 94$ & 247 & 24 & 1,030 & 32 & 334 & 9.4 & 0.8 & $<0.1$ & 382 & 12 & 123 & 4.1 \\
\hline AR34.5 & $08 / 19 / 94$ & 953 & 215 & 2,100 & 616 & 192 & 4.2 & 0.5 & $<0.1$ & 200 & 12 & 66 & 3.7 \\
\hline AR31.0 & $08 / 19 / 94$ & 214 & 21 & 898 & 28 & 290 & 8.2 & 0.7 & $<0.1$ & 332 & 10 & 107 & 3.6 \\
\hline AR34.5 & $08 / 20 / 94$ & 976 & 220 & 2,150 & 631 & 197 & 4.3 & 0.5 & $<0.1$ & 205 & 13 & 68 & 3.8 \\
\hline AR31.0 & $08 / 20 / 94$ & 214 & 21 & 898 & 28 & 290 & 8.2 & 0.7 & $<0.1$ & 332 & 10 & 107 & 3.6 \\
\hline AR34.5 & $08 / 21 / 94$ & 953 & 215 & 2,100 & 616 & 192 & 4.2 & 0.5 & $<0.1$ & 200 & 12 & 66 & 3.7 \\
\hline AR31.0 & $08 / 21 / 94$ & 214 & 21 & 898 & 28 & 290 & 8.2 & 0.7 & $<0.1$ & 332 & 10 & 107 & 3.6 \\
\hline AR34.5 & $08 / 22 / 94$ & 930 & 210 & 2,050 & 602 & 188 & 4.1 & 0.5 & $<0.1$ & 195 & 12 & 64 & 3.6 \\
\hline AR31.0 & $08 / 22 / 94$ & 196 & 19 & 823 & 26 & 266 & 7.5 & 0.6 & $<0.1$ & 304 & 9.5 & 98 & 3.3 \\
\hline AR34.5 & $08 / 23 / 94$ & 749 & 169 & 1,650 & 484 & 151 & 3.3 & 0.4 & $<0.1$ & 157 & 9.8 & 52 & 2.9 \\
\hline AR31.0 & $08 / 23 / 94$ & 170 & 17 & 711 & 22 & 230 & 6.5 & 0.6 & $<0.1$ & 263 & 8.2 & 84 & 2.8 \\
\hline AR34.5 & $08 / 24 / 94$ & 681 & 154 & 1,500 & 440 & 137 & 3.0 & 0.3 & $<0.1$ & 143 & 8.9 & 47 & 2.7 \\
\hline AR31.0 & $08 / 24 / 94$ & 158 & 15 & 661 & 20 & 214 & 6.0 & 0.5 & $<0.1$ & 244 & 7.6 & 78 & 2.6 \\
\hline AR34.5 & $08 / 25 / 94$ & 772 & 174 & 1,700 & 499 & 156 & 3.4 & 0.4 & $<0.1$ & 162 & 10 & 53 & 3.0 \\
\hline AR31.0 & $08 / 25 / 94$ & 158 & 15 & 661 & 20 & 214 & 6.0 & 0.5 & $<0.1$ & 244 & 7.6 & 78 & 2.6 \\
\hline AR34.5 & $08 / 26 / 94$ & 817 & 184 & 1,800 & 528 & 165 & 3.6 & 0.4 & $<0.1$ & 171 & 11 & 57 & 3.2 \\
\hline AR31.0 & $08 / 26 / 94$ & 158 & 15 & 661 & 20 & 214 & 6.0 & 0.5 & $<0.1$ & 244 & 7.6 & 78 & 2.6 \\
\hline AR34.5 & $08 / 27 / 94$ & 658 & 148 & 1,450 & 426 & 133 & 2.9 & 0.3 & $<0.1$ & 138 & 8.6 & 46 & 2.6 \\
\hline AR31.0 & $08 / 27 / 94$ & 158 & 15 & 661 & 20 & 214 & 6.0 & 0.5 & $<0.1$ & 244 & 7.6 & 78 & 2.6 \\
\hline AR34.5 & $08 / 28 / 94$ & 817 & 184 & 1,800 & 528 & 165 & 3.6 & 0.4 & $<0.1$ & 171 & 11 & 57 & 3.2 \\
\hline AR31.0 & $08 / 28 / 94$ & 161 & 16 & 673 & 21 & 218 & 6.1 & 0.5 & $<0.1$ & 249 & 7.8 & 80 & 2.7 \\
\hline AR34.5 & $08 / 29 / 94$ & 681 & 154 & 1,500 & 440 & 137 & 3.0 & 0.3 & $<0.1$ & 143 & 8.9 & 47 & 2.7 \\
\hline AR31.0 & $08 / 29 / 94$ & 161 & 16 & 673 & 21 & 218 & 6.1 & 0.5 & $<0.1$ & 249 & 7.8 & 80 & 2.7 \\
\hline AR34.5 & 08/30/94 & 703 & 159 & 1,550 & 455 & 142 & 3.1 & 0.4 & $<0.1$ & 148 & 9.2 & 49 & 2.8 \\
\hline AR31.0 & $08 / 30 / 94$ & 161 & 16 & 673 & 21 & 218 & 6.1 & 0.5 & $<0.1$ & 249 & 7.8 & 80 & 2.7 \\
\hline AR34.5 & $08 / 31 / 94$ & 613 & 138 & 1,350 & 396 & 124 & 2.7 & 0.3 & $<0.1$ & 128 & 8.0 & 42 & 2.4 \\
\hline AR31.0 & $08 / 31 / 94$ & 161 & 16 & 673 & 21 & 218 & 6.1 & 0.5 & $<0.1$ & 249 & 7.8 & 80 & 2.7 \\
\hline AR34.5 & $09 / 01 / 94$ & 930 & 210 & 2,050 & 602 & 188 & 4.1 & 0.5 & $<0.1$ & 195 & 12 & 64 & 3.6 \\
\hline AR31.0 & $09 / 01 / 94$ & 134 & 13 & 561 & 17 & 181 & 5.1 & 0.4 & $<0.1$ & 207 & 6.5 & 67 & 2.2 \\
\hline
\end{tabular}


Table 7. Estimated daily total-metal loads and standard errors for sites AR34.5 and AR31.0, April 1994 through March 1995-Continued

[Loads and standard errors are in pounds per day; <, less than; --, no data]

\begin{tabular}{|c|c|c|c|c|c|c|c|c|c|c|c|c|c|}
\hline \multirow[b]{2}{*}{ Site } & \multirow[b]{2}{*}{ Date } & \multicolumn{2}{|c|}{ Aluminum } & \multicolumn{2}{|c|}{ Iron } & \multicolumn{2}{|c|}{ Copper } & \multicolumn{2}{|c|}{ Cadmlum } & \multicolumn{2}{|c|}{ Manganese } & \multicolumn{2}{|c|}{ Zinc } \\
\hline & & Load & $\begin{array}{l}\text { Standard } \\
\text { error }\end{array}$ & Load & $\begin{array}{l}\text { Standard } \\
\text { error }\end{array}$ & Load & $\begin{array}{l}\text { Standard } \\
\text { error }\end{array}$ & Load & $\begin{array}{l}\text { Standard } \\
\text { error }\end{array}$ & Load & $\begin{array}{l}\text { Standard } \\
\text { error }\end{array}$ & Load & $\begin{array}{l}\text { Standard } \\
\text { error }\end{array}$ \\
\hline$\overline{\mathrm{AR} 34.5}$ & $09 / 02 / 94$ & 2,980 & -- & 6,110 & -- & 276 & -- & $\overline{0.6}$ & - & 272 & - & 83 & -- \\
\hline AR31.0 & $09 / 02 / 94$ & 116 & 11 & 486 & 15 & 157 & 4.4 & 0.4 & $<0.1$ & 180 & 5.6 & 58 & 1.9 \\
\hline AR34.5 & $09 / 03 / 94$ & 11,300 & -- & 23,200 & -- & 1,050 & -- & 2.1 & -- & 1,030 & -- & 314 & -- \\
\hline AR31.0 & $09 / 03 / 94$ & 116 & 11 & 486 & 15 & 157 & 4.4 & 0.4 & $<0.1$ & 180 & 5.6 & 58 & 1.9 \\
\hline AR34.5 & $09 / 04 / 94$ & 8,550 & -- & 17,600 & -- & 794 & -- & 1.6 & -- & 781 & -- & 237 & -- \\
\hline AR31.0 & $09 / 04 / 94$ & 199 & 20 & 835 & 26 & 270 & 7.6 & 0.7 & $<0.1$ & 309 & 9.6 & 99 & 3.3 \\
\hline AR34.5 & $09 / 05 / 94$ & 6,020 & -- & 12,400 & -- & 559 & -- & 1.1 & -- & 550 & -- & 167 & -- \\
\hline AR31.0 & $09 / 05 / 94$ & 259 & 25 & 1,080 & 34 & 350 & 9.9 & 0.8 & $<0.1$ & 401 & 12 & 129 & 4.3 \\
\hline AR34.5 & $09 / 06 / 94$ & 4,760 & -- & 9,770 & -- & 442 & - & 0.9 & -- & 435 & -- & 132 & -- \\
\hline AR31.0 & $09 / 06 / 94$ & 259 & 25 & 1,080 & 34 & 350 & 9.9 & 0.8 & $<0.1$ & 401 & 12 & 129 & 4.3 \\
\hline AR34.5 & $09 / 07 / 94$ & 928 & -- & 1,880 & -- & 295 & -- & 0.6 & -- & 242 & -- & 91 & -- \\
\hline AR31.0 & $09 / 07 / 94$ & 259 & 25 & 1,080 & 34 & 350 & 9.9 & 0.8 & $<0.1$ & 401 & 12 & 129 & 4.3 \\
\hline AR34.5 & $09 / 08 / 94$ & 860 & -- & 1,740 & -- & 273 & -- & 0.5 & -- & 224 & -- & 85 & -- \\
\hline AR31.0 & $09 / 08 / 94$ & 256 & 25 & 1,070 & 33 & 346 & 9.8 & 0.8 & $<0.1$ & 396 & 12 & 127 & 4.3 \\
\hline AR34.5 & $09 / 09 / 94$ & 742 & -- & 1,500 & -- & 236 & -- & 0.5 & - & 194 & -- & 73 & -- \\
\hline AR31.0 & $09 / 09 / 94$ & 173 & 17 & 723 & 22 & 234 & 6.6 & 0.6 & $<0.1$ & 267 & 8.3 & 86 & 2.9 \\
\hline AR34.5 & $09 / 10 / 94$ & 675 & -- & 1,370 & -- & 214 & -- & 0.4 & -- & 176 & -- & 66 & -- \\
\hline AR31.0 & $09 / 10 / 94$ & 122 & 12 & 511 & 16 & 165 & 4.7 & 0.4 & $<0.1$ & 189 & 5.9 & 61 & 2.0 \\
\hline AR34.5 & $09 / 11 / 94$ & 624 & -- & 1,260 & -- & 198 & -- & 0.4 & - & 163 & -- & 61 & -- \\
\hline AR31.0 & $09 / 11 / 94$ & 122 & 12 & 511 & 16 & 165 & 4.7 & 0.4 & $<0.1$ & 189 & 5.9 & 61 & 2.0 \\
\hline AR34.5 & $09 / 12 / 94$ & 607 & -- & 1,230 & -- & 193 & - & 0.4 & -- & 158 & - & 60 & -- \\
\hline AR31.0 & $09 / 12 / 94$ & 122 & 12 & 511 & 16 & 165 & 4.7 & 0.4 & $<0.1$ & 189 & 5.9 & 61 & 2.0 \\
\hline AR34.5 & $09 / 13 / 94$ & 843 & -- & 1,710 & -- & 268 & -- & 0.5 & -- & 220 & -- & 83 & -- \\
\hline AR31.0 & $09 / 13 / 94$ & 125 & 12 & 524 & 16 & 169 & 4.8 & 0.4 & $<0.1$ & 194 & 6.0 & 62 & 2.1 \\
\hline AR34.5 & $09 / 14 / 94$ & 3,440 & -- & 7,900 & -- & 698 & - & 1.2 & -- & 516 & -- & 216 & -- \\
\hline AR31.0 & $09 / 14 / 94$ & 146 & 14 & 611 & 19 & 197 & 5.6 & 0.5 & $<0.1$ & 226 & 7.1 & 72 & 2.4 \\
\hline AR34.5 & $09 / 15 / 94$ & 1,540 & 139 & 3,020 & 302 & 356 & 32 & 0.8 & $<0.1$ & 332 & 12 & 118 & 5.1 \\
\hline AR31.0 & $09 / 15 / 94$ & 161 & 16 & 673 & 21 & 218 & 6.1 & 0.5 & $<0.1$ & 249 & 7.8 & 80 & 2.7 \\
\hline AR34.5 & $09 / 16 / 94$ & 1,220 & 110 & 2,400 & 240 & 282 & 26 & 0.7 & $<0.1$ & 264 & 9.2 & 94 & 4.1 \\
\hline AR31.0 & $09 / 16 / 94$ & 161 & 16 & 673 & 21 & 218 & 6.1 & 0.5 & $<0.1$ & 249 & 7.8 & 80 & 2.7 \\
\hline AR34.5 & $09 / 17 / 94$ & 1,100 & 99 & 2,150 & 215 & 254 & 23 & 0.6 & $<0.1$ & 237 & 8.3 & 84 & 3.6 \\
\hline AR31.0 & $09 / 17 / 94$ & 161 & 16 & 673 & 21 & 218 & 6.1 & 0.5 & $<0.1$ & 249 & 7.8 & 80 & 2.7 \\
\hline AR34.5 & $09 / 18 / 94$ & 1,070 & 97 & 2,110 & 211 & 248 & 22 & 0.6 & $<0.1$ & 232 & 8.1 & 83 & 3.6 \\
\hline AR31.0 & $09 / 18 / 94$ & 164 & 16 & 686 & 21 & 222 & 6.2 & 0.5 & $<0.1$ & 253 & 7.9 & 81 & 2.7 \\
\hline AR34.5 & $09 / 19 / 94$ & 1,260 & 114 & 2,480 & 248 & 292 & 26 & 0.7 & $<0.1$ & 273 & 9.6 & 97 & 4.2 \\
\hline AR31.0 & $09 / 19 / 94$ & 161 & 16 & 673 & 21 & 218 & 6.1 & 0.5 & $<0.1$ & 249 & 7.8 & 80 & 2.7 \\
\hline AR34.5 & $09 / 20 / 94$ & 1,140 & 103 & 2,230 & 224 & 263 & 24 & 0.6 & $<0.1$ & 246 & 8.6 & 87 & 3.8 \\
\hline AR31.0 & $09 / 20 / 94$ & 161 & 16 & 673 & 21 & 218 & 6.1 & 0.5 & $<0.1$ & 249 & 7.8 & 80 & 2.7 \\
\hline AR34.5 & $09 / 21 / 94$ & 1,160 & 104 & 2,270 & 228 & 268 & 24 & 0.6 & $<0.1$ & 250 & 8.8 & 89 & 3.9 \\
\hline AR31.0 & $09 / 21 / 94$ & 143 & 14 & 598 & 19 & 193 & 5.5 & 0.5 & $<0.1$ & 221 & 6.9 & 71 & 2.4 \\
\hline AR34.5 & $09 / 22 / 94$ & 990 & 89 & 1,940 & 195 & 229 & 21 & 0.5 & $<0.1$ & 214 & 7.5 & 76 & 3.3 \\
\hline AR31.0 & $09 / 22 / 94$ & 134 & 13 & 561 & 17 & 181 & 5.1 & 0.4 & $<0.1$ & 207 & 6.5 & 67 & 2.2 \\
\hline
\end{tabular}


Table 7. Estimated daily total-metal loads and standard errors for sites AR34.5 and AR31.0, April 1994 through March 1995-Continued

[Loads and standard errors are in pounds per day; $<$, less than; --, no data]

\begin{tabular}{|c|c|c|c|c|c|c|c|c|c|c|c|c|c|}
\hline \multirow[b]{2}{*}{ Site } & \multirow[b]{2}{*}{ Date } & \multicolumn{2}{|c|}{ Aluminum } & \multicolumn{2}{|c|}{ Iron } & \multicolumn{2}{|c|}{ Copper } & \multicolumn{2}{|c|}{ Cadmlum } & \multicolumn{2}{|c|}{ Manganese } & \multicolumn{2}{|c|}{ Zinc } \\
\hline & & Load & $\begin{array}{c}\text { Standard } \\
\text { error }\end{array}$ & Load & $\begin{array}{l}\text { Standard } \\
\text { error }\end{array}$ & Load & $\begin{array}{l}\text { Standard } \\
\text { error }\end{array}$ & Load & $\begin{array}{l}\text { Standard } \\
\text { error }\end{array}$ & Load & $\begin{array}{l}\text { Standard } \\
\text { error }\end{array}$ & Load & $\begin{array}{c}\text { Standard } \\
\text { error }\end{array}$ \\
\hline$\overline{\text { AR34.5 }}$ & $09 / 23 / 94$ & 905 & 82 & 1,780 & 178 & 209 & 19 & 0.5 & $<0.1$ & 196 & 6.8 & 70 & 3.0 \\
\hline AR31.0 & $09 / 23 / 94$ & 134 & 13 & 561 & 17 & 181 & 5.1 & 0.4 & $<0.1$ & 207 & 6.5 & 67 & 2.2 \\
\hline AR34.5 & $09 / 24 / 94$ & 905 & 82 & 1,780 & 178 & 209 & 19 & 0.5 & $<0.1$ & 196 & 6.8 & 70 & 3.0 \\
\hline AR31.0 & $09 / 24 / 94$ & 134 & 13 & 561 & 17 & 181 & 5.1 & 0.4 & $<0.1$ & 207 & 6.5 & 67 & 2.2 \\
\hline AR34.5 & $09 / 25 / 94$ & 842 & 76 & 1,650 & 166 & 195 & 18 & 0.4 & $<0.1$ & 182 & 6.4 & 65 & 2.8 \\
\hline AR31.0 & $09 / 25 / 94$ & 134 & 13 & 561 & 17 & 181 & 5.1 & 0.4 & $<0.1$ & 207 & 6.5 & 67 & 2.2 \\
\hline AR34.5 & $09 / 26 / 94$ & 800 & 72 & 1,570 & 157 & 185 & 17 & 0.4 & $<0.1$ & 173 & 6.1 & 62 & 2.7 \\
\hline AR31.0 & $09 / 26 / 94$ & 134 & 13 & 561 & 17 & 181 & 5.1 & 0.4 & $<0.1$ & 207 & 6.5 & 67 & 2.2 \\
\hline AR34.5 & $09 / 27 / 94$ & 716 & 65 & 1,400 & 141 & 166 & 15 & 0.4 & $<0.1$ & 155 & 5.4 & 55 & 2.4 \\
\hline AR31.0 & $09 / 27 / 94$ & 134 & 13 & 561 & 17 & 181 & 5.1 & 0.4 & $<0.1$ & 207 & 6.5 & 67 & 2.2 \\
\hline AR34.5 & $09 / 28 / 94$ & 674 & 61 & 1,320 & 132 & 156 & 14 & 0.4 & $<0.1$ & 146 & 5.1 & 52 & 2.2 \\
\hline AR31.0 & $09 / 28 / 94$ & 134 & 13 & 561 & 17 & 181 & 5.1 & 0.4 & $<0.1$ & 207 & 6.5 & 67 & 2.2 \\
\hline AR34.5 & $09 / 29 / 94$ & 653 & 59 & 1,280 & 128 & 151 & 14 & 0.3 & $<0.1$ & 141 & 4.9 & 50 & 2.2 \\
\hline AR31.0 & $09 / 29 / 94$ & 134 & 13 & 561 & 17 & 181 & 5.1 & 0.4 & $<0.1$ & 207 & 6.5 & 67 & 2.2 \\
\hline AR34.5 & $09 / 30 / 94$ & 653 & 59 & 1,280 & 128 & 151 & 14 & 0.3 & $<0.1$ & 141 & 4.9 & 50 & 2.2 \\
\hline AR31.0 & $09 / 30 / 94$ & 134 & 13 & 561 & 17 & 181 & 5.1 & 0.4 & $<0.1$ & 207 & 6.5 & 67 & 2.2 \\
\hline AR34.5 & $10 / 01 / 94$ & 632 & 57 & 1,240 & 124 & 146 & 13 & 0.3 & $<0.1$ & 136 & 4.8 & 49 & 2.1 \\
\hline AR31.0 & $10 / 01 / 94$ & 152 & 15 & 636 & 20 & 205 & 5.8 & 0.5 & $<0.1$ & 235 & 7.3 & 76 & 2.5 \\
\hline AR34.5 & $10 / 02 / 94$ & 611 & 55 & 1,200 & 120 & 141 & 13 & 0.3 & $<0.1$ & 132 & 4.6 & 47 & 2.0 \\
\hline AR31.0 & $10 / 02 / 94$ & 161 & 16 & 673 & 21 & 218 & 6.1 & 0.5 & $<0.1$ & 249 & 7.8 & 80 & 2.7 \\
\hline AR34.5 & $10 / 03 / 94$ & 590 & 53 & 1,160 & 116 & 136 & 12 & 0.3 & $<0.1$ & 127 & 4.5 & 45 & 2.0 \\
\hline AR31.0 & $10 / 03 / 94$ & 161 & 16 & 673 & 21 & 218 & 6.1 & 0.5 & $<0.1$ & 249 & 7.8 & 80 & 2.7 \\
\hline AR34.5 & $10 / 04 / 94$ & 568 & 51 & 1,120 & 112 & 132 & 12 & 0.3 & $<0.1$ & 123 & 4.3 & 44 & 1.9 \\
\hline AR31.0 & $10 / 04 / 94$ & 161 & 16 & 673 & 21 & 218 & 6.1 & 0.5 & $<0.1$ & 249 & 7.8 & 80 & 2.7 \\
\hline AR34.5 & $10 / 05 / 94$ & 568 & 51 & 1,120 & 112 & 132 & 12 & 0.3 & $<0.1$ & 123 & 4.3 & 44 & 1.9 \\
\hline AR31.0 & $10 / 05 / 94$ & 164 & 16 & 686 & 21 & 222 & 6.2 & 0.5 & $<0.1$ & 253 & 7.9 & 81 & 2.7 \\
\hline AR34.5 & $10 / 06 / 94$ & 568 & 51 & 1,120 & 112 & 132 & 12 & 0.3 & $<0.1$ & 123 & 4.3 & 44 & 1.9 \\
\hline AR31.0 & $10 / 06 / 94$ & 167 & 16 & 698 & 22 & 226 & 6.4 & 0.5 & $<0.1$ & 258 & 8.1 & 83 & 2.8 \\
\hline AR34.5 & $10 / 07 / 94$ & 632 & 57 & 1,240 & 124 & 146 & 13 & 0.3 & $<0.1$ & 136 & 4.8 & 49 & 2.1 \\
\hline AR31.0 & $10 / 07 / 94$ & 167 & 16 & 698 & 22 & 226 & 6.4 & 0.5 & $<0.1$ & 258 & 8.1 & 83 & 2.8 \\
\hline AR34.5 & $10 / 08 / 94$ & 716 & 65 & 1,400 & 141 & 166 & 15 & 0.4 & $<0.1$ & 155 & 5.4 & 55 & 2.4 \\
\hline AR31.0 & $10 / 08 / 94$ & 167 & 16 & 698 & 22 & 226 & 6.4 & 0.5 & $<0.1$ & 258 & 8.1 & 83 & 2.8 \\
\hline AR34.5 & $10 / 09 / 94$ & 758 & 68 & 1,490 & 149 & 175 & 16 & 0.4 & $<0.1$ & 164 & 5.7 & 58 & 2.5 \\
\hline AR31.0 & $10 / 09 / 94$ & 164 & 16 & 686 & 21 & 222 & 6.2 & 0.5 & $<0.1$ & 253 & 7.9 & 81 & 2.7 \\
\hline AR34.5 & $10 / 10 / 94$ & 842 & 76 & 1,650 & 166 & 195 & 18 & 0.4 & $<0.1$ & 182 & 6.4 & 65 & 2.8 \\
\hline AR31.0 & $10 / 10 / 94$ & 161 & 16 & 673 & 21 & 218 & 6.1 & 0.5 & $<0.1$ & 249 & 7.8 & 80 & 2.7 \\
\hline AR34.5 & $10 / 11 / 94$ & 800 & 72 & 1,570 & 157 & 185 & 17 & 0.4 & $<0.1$ & 173 & 6.1 & 62 & 2.7 \\
\hline AR31.0 & $10 / 11 / 94$ & 211 & 21 & 885 & 28 & 286 & 8.1 & 0.7 & $<0.1$ & 327 & 10 & 105 & 3.5 \\
\hline AR34.5 & $10 / 12 / 94$ & 800 & 72 & 1,570 & 157 & 185 & 17 & 0.4 & $<0.1$ & 173 & 6.1 & 62 & 2.7 \\
\hline AR31.0 & $10 / 12 / 94$ & 244 & 24 & 1,020 & 32 & 330 & 9.3 & 0.8 & $<0.1$ & 378 & 12 & 121 & 4.1 \\
\hline AR34.5 & $10 / 13 / 94$ & 779 & 70 & 1,530 & 153 & 180 & 16 & 0.4 & $<0.1$ & 168 & 5.9 & 60 & 2.6 \\
\hline AR31.0 & $10 / 13 / 94$ & 244 & 24 & 1,020 & 32 & 330 & 9.3 & 0.8 & $<0.1$ & 378 & 12 & 121 & 4.1 \\
\hline
\end{tabular}


Table 7. Estimated daily total-metal loads and standard errors for sites AR34.5 and AR31.0, April 1994 through March 1995-Continued

[Loads and standard errors are in pounds per day; <, less than; --, no data]

\begin{tabular}{|c|c|c|c|c|c|c|c|c|c|c|c|c|c|}
\hline \multirow[b]{2}{*}{ Site } & \multirow[b]{2}{*}{ Date } & \multicolumn{2}{|c|}{ Aluminum } & \multicolumn{2}{|c|}{ Iron } & \multicolumn{2}{|c|}{ Copper } & \multicolumn{2}{|c|}{ Cadmium } & \multicolumn{2}{|c|}{ Manganese } & \multicolumn{2}{|c|}{ ZInc } \\
\hline & & Load & $\begin{array}{l}\text { Standard } \\
\text { error }\end{array}$ & Load & $\begin{array}{c}\text { Standard } \\
\text { error }\end{array}$ & Load & $\begin{array}{c}\text { Standard } \\
\text { error }\end{array}$ & Load & $\begin{array}{l}\text { Standard } \\
\text { error }\end{array}$ & Load & $\begin{array}{l}\text { Standard } \\
\text { orror }\end{array}$ & Load & $\begin{array}{l}\text { Standard } \\
\text { error }\end{array}$ \\
\hline$\overline{\text { AR34.5 }}$ & $10 / 14 / 94$ & 779 & 70 & 1,530 & 153 & 180 & 16 & 0.4 & $<0.1$ & 168 & 5.9 & 60 & 2.6 \\
\hline AR31.0 & $10 / 14 / 94$ & 244 & 24 & 1,020 & 32 & 330 & 9.3 & 0.8 & $<0.1$ & 378 & 12 & 121 & 4.1 \\
\hline AR34.5 & $10 / 15 / 94$ & 737 & 66 & 1,450 & 145 & 170 & 15 & 0.4 & $<0.1$ & 159 & 5.6 & 57 & 2.5 \\
\hline AR31.0 & $10 / 15 / 94$ & 202 & 20 & 848 & 26 & 274 & 7.7 & 0.7 & $<0.1$ & 313 & 9.8 & 101 & 3.4 \\
\hline AR34.5 & $10 / 16 / 94$ & 758 & 68 & 1,490 & 149 & 175 & 16 & 0.4 & $<0.1$ & 164 & 5.7 & 58 & 2.5 \\
\hline AR31.0 & $10 / 16 / 94$ & 184 & 18 & 773 & 24 & 250 & 7.0 & 0.6 & $<0.1$ & 286 & 8.9 & 92 & 3.1 \\
\hline AR34.5 & $10 / 17 / 94$ & 821 & 74 & 1,610 & 162 & 190 & 17 & 0.4 & $<0.1$ & 178 & 6.2 & 63 & 2.7 \\
\hline AR31.0 & $10 / 17 / 94$ & 184 & 18 & 773 & 24 & 250 & 7.0 & 0.6 & $<0.1$ & 286 & 8.9 & 92 & 3.1 \\
\hline AR34.5 & $10 / 18 / 94$ & 758 & 68 & 1,490 & 149 & 175 & 16 & 0.4 & $<0.1$ & 164 & 5.7 & 58 & 2.5 \\
\hline AR31.0 & $10 / 18 / 94$ & 184 & 18 & 773 & 24 & 250 & 7.0 & 0.6 & $<0.1$ & 286 & 8.9 & 92 & 3.1 \\
\hline AR34.5 & $10 / 19 / 94$ & 695 & 63 & 1,360 & 137 & 161 & 15 & 0.4 & $<0.1$ & 150 & 5.3 & 53 & 2.3 \\
\hline AR31.0 & $10 / 19 / 94$ & 184 & 18 & 773 & 24 & 250 & 7.0 & 0.6 & $<0.1$ & 286 & 8.9 & 92 & 3.1 \\
\hline AR34.5 & $10 / 20 / 94$ & 695 & 63 & 1,360 & 137 & 161 & 15 & 0.4 & $<0.1$ & 150 & 5.3 & 53 & 2.3 \\
\hline AR31.0 & $10 / 20 / 94$ & 161 & 16 & 673 & 21 & 218 & 6.1 & 0.5 & $<0.1$ & 249 & 7.8 & 80 & 2.7 \\
\hline AR34.5 & $10 / 21 / 94$ & 674 & 61 & 1,320 & 132 & 156 & 14 & 0.4 & $<0.1$ & 146 & 5.1 & 52 & 2.2 \\
\hline AR31.0 & $10 / 21 / 94$ & 155 & 15 & 648 & 20 & 210 & 5.9 & 0.5 & $<0.1$ & 240 & 7.5 & 77 & 2.6 \\
\hline AR34.5 & $10 / 22 / 94$ & 674 & 61 & 1,320 & 132 & 156 & 14 & 0.4 & $<0.1$ & 146 & 5.1 & 52 & 2.2 \\
\hline AR31.0 & $10 / 22 / 94$ & 155 & 15 & 648 & 20 & 210 & 5.9 & 0.5 & $<0.1$ & 240 & 7.5 & 77 & 2.6 \\
\hline AR34.5 & $10 / 23 / 94$ & 674 & 61 & 1,320 & 132 & 156 & 14 & 0.4 & $<0.1$ & 146 & 5.1 & 52 & 2.2 \\
\hline AR31.0 & $10 / 23 / 94$ & 155 & 15 & 648 & 20 & 210 & 5.9 & 0.5 & $<0.1$ & 240 & 7.5 & 77 & 2.6 \\
\hline AR34.5 & $10 / 24 / 94$ & 370 & 37 & 755 & 94 & 36 & 6.2 & 0.2 & $<0.1$ & 88 & 7.8 & 23 & 1.8 \\
\hline AR31.0 & $10 / 24 / 94$ & 155 & 15 & 648 & 20 & 210 & 5.9 & 0.5 & $<0.1$ & 240 & 7.5 & 77 & 2.6 \\
\hline AR34.5 & $10 / 25 / 94$ & 356 & 36 & 728 & 91 & 34 & 6.0 & 0.1 & $<0.1$ & 85 & 7.6 & 22 & 1.8 \\
\hline AR31.0 & $10 / 25 / 94$ & 155 & 15 & 648 & 20 & 210 & 5.9 & 0.5 & $<0.1$ & 240 & 7.5 & 77 & 2.6 \\
\hline AR34.5 & $10 / 26 / 94$ & 396 & 40 & 809 & 101 & 38 & 6.7 & 0.2 & $<0.1$ & 95 & 8.4 & 25 & 1.9 \\
\hline AR31.0 & $10 / 26 / 94$ & 155 & 15 & 648 & 20 & 210 & 5.9 & 0.5 & $<0.1$ & 240 & 7.5 & 77 & 2.6 \\
\hline AR34.5 & $10 / 27 / 94$ & 290 & 29 & 593 & 74 & 28 & 4.9 & 0.1 & $<0.1$ & 69 & 6.2 & 18 & 1.4 \\
\hline AR31.0 & $10 / 27 / 94$ & 155 & 15 & 648 & 20 & 210 & 5.9 & 0.5 & $<0.1$ & 240 & 7.5 & 77 & 2.6 \\
\hline AR34.5 & $10 / 28 / 94$ & 370 & 37 & 755 & 94 & 36 & 6.2 & 0.2 & $<0.1$ & 88 & 7.8 & 23 & 1.8 \\
\hline AR31.0 & $10 / 28 / 94$ & 155 & 15 & 648 & 20 & 210 & 5.9 & 0.5 & $<0.1$ & 240 & 7.5 & 77 & 2.6 \\
\hline AR34.5 & $10 / 29 / 94$ & 396 & 40 & 809 & 101 & 38 & 6.7 & 0.2 & $<0.1$ & 95 & 8.4 & 25 & 1.9 \\
\hline AR31.0 & $10 / 29 / 94$ & 155 & 15 & 648 & 20 & 210 & 5.9 & 0.5 & $<0.1$ & 240 & 7.5 & 77 & 2.6 \\
\hline AR34.5 & $10 / 30 / 94$ & 277 & 28 & 566 & 71 & 27 & 4.7 & 0.1 & $<0.1$ & 66 & 5.9 & 17 & 1.4 \\
\hline AR31.0 & $10 / 30 / 94$ & 155 & 15 & 648 & 20 & 210 & 5.9 & 0.5 & $<0.1$ & 240 & 7.5 & 77 & 2.6 \\
\hline AR34.5 & $10 / 31 / 94$ & 488 & 49 & 997 & 125 & 47 & 8.2 & 0.2 & $<0.1$ & 117 & 10.4 & 30 & 2.4 \\
\hline AR31.0 & $10 / 31 / 94$ & 155 & 15 & 648 & 20 & 210 & 5.9 & 0.5 & $<0.1$ & 240 & 7.5 & 77 & 2.6 \\
\hline AR34.5 & $11 / 01 / 94$ & 383 & 38 & 782 & 98 & 37 & 6.4 & 0.2 & $<0.1$ & 92 & 8.1 & 24 & 1.9 \\
\hline AR31.0 & $11 / 01 / 94$ & 104 & 10 & 436 & 14 & 141 & 4.0 & 0.3 & $<0.1$ & 161 & 5.0 & 52 & 1.7 \\
\hline AR34.5 & $11 / 02 / 94$ & 356 & 36 & 728 & 91 & 34 & 6.0 & 0.1 & $<0.1$ & 85 & 7.6 & 22 & 1.8 \\
\hline AR31.0 & $11 / 02 / 94$ & 7.5 & -- & 11 & -- & 4.8 & -- & $<0.1$ & -- & 10 & - & 4.1 & -- \\
\hline AR34.5 & $11 / 03 / 94$ & 304 & 30 & 620 & 77.5 & 29 & 5.1 & 0.1 & $<0.1$ & 73 & 6.4 & 19 & 1.5 \\
\hline AR31.0 & $11 / 03 / 94$ & 7.7 & -- & 12 & -- & 4.9 & -- & $<0.1$ & -- & 11 & -- & 4.3 & - \\
\hline
\end{tabular}


Table 7. Estimated daily total-metal loads and standard errors for sites AR34.5 and AR31.0, April 1994 through March 1995-Continued

[Loads and standard errors are in pounds per day; <, less than; --, no data]

\begin{tabular}{|c|c|c|c|c|c|c|c|c|c|c|c|c|c|}
\hline \multirow[b]{2}{*}{ Site } & \multirow[b]{2}{*}{ Date } & \multicolumn{2}{|c|}{ Aluminum } & \multicolumn{2}{|c|}{ Iron } & \multicolumn{2}{|c|}{ Copper } & \multicolumn{2}{|c|}{ Cadmium } & \multicolumn{2}{|c|}{ Manganese } & \multicolumn{2}{|c|}{ Żnc } \\
\hline & & Load & $\begin{array}{l}\text { Standard } \\
\text { error }\end{array}$ & Load & $\begin{array}{c}\text { Standard } \\
\text { error }\end{array}$ & Load & $\begin{array}{l}\text { Standard } \\
\text { orror }\end{array}$ & Load & $\begin{array}{c}\text { Standard } \\
\text { error }\end{array}$ & Load & $\begin{array}{l}\text { Standard } \\
\text { error }\end{array}$ & Load & $\begin{array}{l}\text { Standard } \\
\text { error }\end{array}$ \\
\hline$\overline{\text { AR34.5 }}$ & $11 / 04 / 94$ & 317 & 32 & 647 & 80.8 & 31 & 5.3 & 0.1 & $<0.1$ & 76 & 6.7 & 20 & 1.6 \\
\hline AR31.0 & $11 / 04 / 94$ & 5.4 & -- & 8.3 & -- & 3.5 & -. & $<0.1$ & - & 7.5 & -- & 3.0 & -- \\
\hline AR34.5 & $11 / 05 / 94$ & 290 & 29 & 593 & 74.1 & 28 & 4.9 & 0.1 & $<0.1$ & 69 & 6.2 & 18 & 1.4 \\
\hline AR31.0 & $11 / 05 / 94$ & 3.2 & -- & 4.8 & -- & 2.0 & -- & $<0.1$ & -- & 4.3 & -- & 1.7 & -- \\
\hline AR34.5 & $11 / 06 / 94$ & 264 & 26 & 539 & 67.4 & 26 & 4.4 & 0.1 & $<0.1$ & 63 & 5.6 & 16 & 1.3 \\
\hline AR31.0 & $11 / 06 / 94$ & 2.9 & -- & 4.3 & -- & 1.8 & -- & $<0.1$ & - & 3.9 & -- & 1.6 & -- \\
\hline AR34.5 & $11 / 07 / 94$ & 277 & 28 & 566 & 70.7 & 27 & 4.7 & 0.1 & $<0.1$ & 66 & 5.9 & 17 & 1.4 \\
\hline AR31.0 & $11 / 07 / 94$ & 1.7 & -- & 2.6 & -- & 1.1 & -- & $<0.1$ & - & 2.3 & -- & 0.9 & - \\
\hline AR34.5 & $11 / 08 / 94$ & 290 & 29 & 593 & 74.1 & 28 & 4.9 & 0.1 & $<0.1$ & 69 & 6.2 & 18 & 1.4 \\
\hline AR31.0 & $11 / 08 / 94$ & 0.9 & -- & 1.3 & -- & 0.5 & -- & $<0.1$ & - & 1.2 & -- & 0.5 & - \\
\hline AR34.5 & $11 / 09 / 94$ & 304 & 30 & 620 & 77.5 & 29 & 5.1 & 0.1 & $<0.1$ & 73 & 6.4 & 19 & 1.5 \\
\hline AR31.0 & $11 / 09 / 94$ & 0.8 & -- & 1.3 & -- & 0.5 & -- & $<0.1$ & -- & 1.1 & -- & 0.5 & -- \\
\hline AR34.5 & $11 / 10 / 94$ & 317 & 32 & 647 & 80.8 & 31 & 5.3 & 0.1 & $<0.1$ & 76 & 6.7 & 20 & 1.6 \\
\hline AR31.0 & $11 / 10 / 94$ & 0.9 & -- & 1.3 & -- & 0.5 & -- & $<0.1$ & -- & 1.2 & -- & 0.5 & -- \\
\hline AR34.5 & $11 / 11 / 94$ & 343 & 34 & 701 & 87.6 & 33 & 5.8 & 0.1 & $<0.1$ & 82 & 7.3 & 21 & 1.7 \\
\hline AR31.0 & $11 / 11 / 94$ & 0.9 & - & 1.3 & - & 0.6 & - & $<0.1$ & - & 1.2 & - & 0.5 & -- \\
\hline AR34.5 & $11 / 12 / 94$ & 356 & 36 & 728 & 91.0 & 34 & 6.0 & 0.1 & $<0.1$ & 85 & 7.6 & 22 & 1.8 \\
\hline AR31.0 & $11 / 12 / 94$ & 0.9 & -- & 1.4 & -- & 0.6 & -- & $<0.1$ & - & 1.3 & - & 0.5 & -- \\
\hline AR34.5 & $11 / 13 / 94$ & 317 & 32 & 647 & 80.8 & 31 & 5.3 & 0.1 & $<0.1$ & 76 & 6.7 & 20 & 1.6 \\
\hline AR31.0 & $11 / 13 / 94$ & 0.9 & -- & 1.3 & -- & 0.6 & -- & $<0.1$ & - & 1.2 & -- & 0.5 & -- \\
\hline AR34.5 & $11 / 14 / 94$ & 304 & 30 & 620 & 78 & 29 & 5.1 & 0.1 & $<0.1$ & 73 & 6.4 & 19 & 1.5 \\
\hline AR31.0 & $11 / 14 / 94$ & 0.9 & -- & 1.3 & -- & 0.6 & -- & $<0.1$ & - & 1.2 & -- & 0.5 & -- \\
\hline AR34.5 & $11 / 15 / 94$ & 277 & 28 & 566 & 71 & 27 & 4.7 & 0.1 & $<0.1$ & 66 & 5.9 & 17 & 1.4 \\
\hline AR31.0 & $11 / 15 / 94$ & 0.9 & -- & 1.4 & -- & 0.6 & -- & $<0.1$ & - & 1.3 & -- & 0.5 & -- \\
\hline AR34.5 & $11 / 16 / 94$ & 251 & 25 & 512 & 64 & 24 & 4.2 & 0.1 & $<0.1$ & 60 & 5.3 & 16 & 1.2 \\
\hline AR31.0 & $11 / 16 / 94$ & 0.9 & -- & 1.4 & -- & 0.6 & -- & $<0.1$ & - & 1.3 & -- & 0.5 & -- \\
\hline AR34.5 & $11 / 17 / 94$ & 251 & 25 & 512 & 64 & 24 & 4.2 & 0.1 & $<0.1$ & 60 & 5.3 & 16 & 1.2 \\
\hline AR31.0 & $11 / 17 / 94$ & 0.9 & - & 1.4 & -- & 0.6 & -- & $<0.1$ & -- & 1.3 & -- & 0.5 & -- \\
\hline AR34.5 & $11 / 18 / 94$ & 238 & 24 & 485 & 61 & 23 & 4.0 & 0.1 & $<0.1$ & 57 & 5.0 & 15 & 1.2 \\
\hline AR31.0 & $11 / 18 / 94$ & 0.9 & -- & 1.4 & -- & 0.6 & -- & $<0.1$ & - & 1.3 & -- & 0.5 & -- \\
\hline AR34.5 & $11 / 19 / 94$ & 251 & 25 & 512 & 64 & 24 & 4.2 & 0.1 & $<0.1$ & 60 & 5.3 & 16 & 1.2 \\
\hline AR31.0 & $11 / 19 / 94$ & 0.9 & -- & 1.4 & -- & 0.6 & -- & $<0.1$ & -- & 1.3 & - & 0.5 & -- \\
\hline AR34.5 & $11 / 20 / 94$ & 238 & 24 & 485 & 61 & 23 & 4.0 & 0.1 & $<0.1$ & 57 & 5.0 & 15 & 1.2 \\
\hline AR31.0 & $11 / 20 / 94$ & 1.0 & - & 1.5 & -- & 0.6 & - & $<0.1$ & - & 1.3 & -- & 0.5 & -- \\
\hline AR34.5 & $11 / 21 / 94$ & 251 & 25 & 512 & 64 & 24 & 4.2 & 0.1 & $<0.1$ & 60 & 5.3 & 16 & 1.2 \\
\hline AR31.0 & $11 / 21 / 94$ & 1.0 & -- & 1.5 & -- & 0.6 & -- & $<0.1$ & - & 1.3 & -- & 0.5 & -- \\
\hline AR34.5 & $11 / 22 / 94$ & 277 & 28 & 566 & 71 & 27 & 4.7 & 0.1 & $<0.1$ & 66 & 5.9 & 17 & 1.4 \\
\hline AR31.0 & $11 / 22 / 94$ & 0.9 & -- & 1.4 & -- & 0.6 & -- & $<0.1$ & - & 1.3 & -- & 0.5 & -- \\
\hline AR34.5 & $11 / 23 / 94$ & 317 & 32 & 647 & 81 & 31 & 5.3 & 0.1 & $<0.1$ & 76 & 6.7 & 20 & 1.6 \\
\hline AR31.0 & $11 / 23 / 94$ & 1.0 & -- & 1.5 & -- & 0.6 & -- & $<0.1$ & -- & 1.4 & -- & 0.6 & -- \\
\hline AR34.5 & $11 / 24 / 94$ & 264 & 26 & 539 & 67 & 26 & 4.4 & 0.1 & $<0.1$ & 63 & 5.6 & 16 & 1.3 \\
\hline AR31.0 & $11 / 24 / 94$ & 1.0 & -- & 1.5 & -- & 0.6 & -- & $<0.1$ & -- & 1.4 & -- & 0.6 & -- \\
\hline
\end{tabular}


Table 7. Estimated daily total-metal loads and standard errors for sites AR34.5 and AR31.0, April 1994 through March 1995-Continued

[Loads and standard errors are in pounds per day; <, less than; --, no data]

\begin{tabular}{|c|c|c|c|c|c|c|c|c|c|c|c|c|c|}
\hline \multirow[b]{2}{*}{ Site } & \multirow[b]{2}{*}{ Date } & \multicolumn{2}{|c|}{ Aluminum } & \multicolumn{2}{|c|}{ iron } & \multicolumn{2}{|c|}{ Copper } & \multicolumn{2}{|c|}{ Cadmium } & \multicolumn{2}{|c|}{ Manganese } & \multicolumn{2}{|c|}{ Żinc } \\
\hline & & Load & $\begin{array}{l}\text { Standard } \\
\text { orror }\end{array}$ & Load & $\begin{array}{l}\text { Standard } \\
\text { error }\end{array}$ & Load & $\begin{array}{l}\text { Standard } \\
\text { error }\end{array}$ & Load & $\begin{array}{l}\text { Standard } \\
\text { orror }\end{array}$ & Load & $\begin{array}{c}\text { Standard } \\
\text { orror }\end{array}$ & Load & $\begin{array}{l}\text { Standard } \\
\text { error }\end{array}$ \\
\hline$\overline{\text { AR34.5 }}$ & $11 / 25 / 94$ & 238 & 24 & 485 & 61 & 23 & 4.0 & 0.1 & $<0.1$ & 57 & 5.0 & 15 & 1.2 \\
\hline AR31.0 & $11 / 25 / 94$ & 1.0 & -- & 1.5 & - & 0.6 & - & $<0.1$ & - & 1.4 & -- & 0.6 & -- \\
\hline AR34.5 & $11 / 26 / 94$ & 211 & 21 & 431 & 54 & 20 & 3.5 & 0.1 & $<0.1$ & 50 & 4.5 & 13 & 1.0 \\
\hline AR31.0 & $11 / 26 / 94$ & 1.0 & -- & 1.5 & -- & 0.6 & - & $<0.1$ & -- & 1.4 & -- & 0.6 & - \\
\hline AR34.5 & $11 / 27 / 94$ & 238 & 24 & 485 & 61 & 23 & 4.0 & 0.1 & $<0.1$ & 57 & 5.0 & 15 & 1.2 \\
\hline AR31.0 & $11 / 27 / 94$ & 1.0 & -- & 1.5 & -- & 0.6 & -- & $<0.1$ & -- & 1.4 & -- & 0.6 & - \\
\hline AR34.5 & $11 / 28 / 94$ & 251 & 25 & 512 & 64 & 24 & 4.2 & 0.1 & $<0.1$ & 60 & 5.3 & 16 & 1.2 \\
\hline AR31.0 & $11 / 28 / 94$ & 1.0 & -- & 1.5 & - & 0.6 & - & $<0.1$ & - & 1.4 & -- & 0.6 & -- \\
\hline AR34.5 & $11 / 29 / 94$ & 264 & 26 & 539 & 67 & 26 & 4.4 & 0.1 & $<0.1$ & 63 & 5.6 & 16 & 1.3 \\
\hline AR31.0 & $11 / 29 / 94$ & 1.0 & -- & 1.5 & -- & 0.6 & -- & $<0.1$ & -- & 1.4 & -- & 0.6 & - \\
\hline AR34.5 & $11 / 30 / 94$ & 277 & 28 & 566 & 71 & 27 & 4.7 & 0.1 & $<0.1$ & 66 & 5.9 & 17 & 1.4 \\
\hline AR31.0 & $11 / 30 / 94$ & 0.9 & -- & 1.3 & - & 0.6 & -- & $<0.1$ & -- & 1.2 & -- & 0.5 & -- \\
\hline AR34.5 & $12 / 01 / 94$ & 277 & 28 & 566 & 71 & 27 & 4.7 & 0.1 & $<0.1$ & 66 & 5.9 & 17 & 1.4 \\
\hline AR31.0 & $12 / 01 / 94$ & 0.8 & - & 1.3 & -- & 0.5 & -- & $<0.1$ & - & 1.1 & -- & 0.5 & - \\
\hline AR34.5 & $12 / 02 / 94$ & 264 & 26 & 539 & 67 & 26 & 4.4 & 0.1 & $<0.1$ & 63 & 5.6 & 16 & 1.3 \\
\hline AR31.0 & $12 / 02 / 94$ & 0.8 & -- & 1.3 & -- & 0.5 & -- & $<0.1$ & - & 1.1 & - & 0.5 & -- \\
\hline AR34.5 & $12 / 03 / 94$ & 251 & 25 & 512 & 64 & 24 & 4.2 & 0.1 & $<0.1$ & 60 & 5.3 & 16 & 1.2 \\
\hline AR31.0 & $12 / 03 / 94$ & 0.8 & -- & 1.3 & -- & 0.5 & -- & $<0.1$ & - & 1.1 & - & 0.5 & -- \\
\hline AR34.5 & $12 / 04 / 94$ & 238 & 24 & 485 & 61 & 23 & 4.0 & 0.1 & $<0.1$ & 57 & 5.0 & 15 & 1.2 \\
\hline AR31.0 & $12 / 04 / 94$ & 0.8 & -- & 1.3 & -- & 0.5 & -- & $<0.1$ & - & 1.1 & -- & 0.5 & -- \\
\hline AR34.5 & $12 / 05 / 94$ & 251 & 25 & 512 & 64 & 24 & 4.2 & 0.1 & $<0.1$ & 60 & 5.3 & 16 & 1.2 \\
\hline AR31.0 & $12 / 05 / 94$ & 0.8 & -- & 1.3 & -- & 0.5 & - & $<0.1$ & - & 1.1 & -- & 0.5 & - \\
\hline AR34.5 & $12 / 06 / 94$ & 238 & 24 & 485 & 61 & 23 & 4.0 & 0.1 & $<0.1$ & 57 & 5.0 & 15 & 1.2 \\
\hline AR31.0 & $12 / 06 / 94$ & 0.9 & - & 1.3 & -- & 0.5 & -- & $<0.1$ & - & 1.2 & -- & 0.5 & - \\
\hline AR34.5 & $12 / 07 / 94$ & 238 & 24 & 485 & 61 & 23 & 4.0 & 0.1 & $<0.1$ & 57 & 5.0 & 15 & 1.2 \\
\hline AR31.0 & $12 / 07 / 94$ & 0.9 & -- & 1.3 & -- & 0.6 & -- & $<0.1$ & -- & 1.2 & -- & 0.5 & - \\
\hline AR34.5 & $12 / 08 / 94$ & 238 & 24 & 485 & 61 & 23 & 4.0 & 0.1 & $<0.1$ & 57 & 5.0 & 15 & 1.2 \\
\hline AR31.0 & $12 / 08 / 94$ & 0.9 & -- & 1.3 & - & 0.6 & - & $<0.1$ & - & 1.2 & -- & 0.5 & -- \\
\hline AR34.5 & $12 / 09 / 94$ & 251 & 25 & 512 & 64 & 24 & 4.2 & 0.1 & $<0.1$ & 60 & 5.3 & 16 & 1.2 \\
\hline AR31.0 & $12 / 09 / 94$ & 0.9 & - & 1.3 & -- & 0.6 & -- & $<0.1$ & - & 1.2 & - & 0.5 & -- \\
\hline AR34.5 & $12 / 10 / 94$ & 264 & 26 & 539 & 67 & 26 & 4.4 & 0.1 & $<0.1$ & 63 & 5.6 & 16 & 1.3 \\
\hline AR31.0 & $12 / 10 / 94$ & 0.9 & -- & 1.3 & -- & 0.6 & -- & $<0.1$ & - & 1.2 & - & 0.5 & - \\
\hline AR34.5 & $12 / 11 / 94$ & 251 & 25 & 512 & 64 & 24 & 4.2 & 0.1 & $<0.1$ & 60 & 5.3 & 16 & 1.2 \\
\hline AR31.0 & $12 / 11 / 94$ & 0.9 & -- & 1.3 & - & 0.6 & -- & $<0.1$ & - & 1.2 & - & 0.5 & - \\
\hline AR34.5 & $12 / 12 / 94$ & 264 & 26 & 539 & 67 & 26 & 4.4 & 0.1 & $<0.1$ & 63 & 5.6 & 16 & 1.3 \\
\hline AR31.0 & $12 / 12 / 94$ & 0.9 & - & 1.3 & - & 0.6 & - & $<0.1$ & - & 1.2 & -- & 0.5 & - \\
\hline AR34.5 & $12 / 13 / 94$ & 238 & 24 & 485 & 61 & 23 & 4.0 & 0.1 & $<0.1$ & 57 & 5.0 & 15 & 1.2 \\
\hline AR31.0 & $12 / 13 / 94$ & 0.9 & -- & 1.3 & -- & 0.6 & -- & $<0.1$ & -- & 1.2 & -- & 0.5 & -- \\
\hline AR34.5 & $12 / 14 / 94$ & 224 & 22 & 458 & 57 & 22 & 3.8 & 0.1 & $<0.1$ & 54 & 4.8 & 14 & 1.1 \\
\hline AR31.0 & $12 / 14 / 94$ & 0.9 & -- & 1.3 & -- & 0.6 & - & $<0.1$ & -- & 1.2 & - & 0.5 & - \\
\hline AR34.5 & $12 / 15 / 94$ & 238 & 24 & 485 & 61 & 23 & 4.0 & 0.1 & $<0.1$ & 57 & 5.0 & 15 & 1.2 \\
\hline AR31.0 & $12 / 15 / 94$ & 0.9 & -- & 1.3 & -- & 0.6 & -- & $<0.1$ & - & 1.2 & -- & 0.5 & -- \\
\hline
\end{tabular}


Table 7. Estimated daily total-metal loads and standard errors for sites AR34.5 and AR31.0, April 1994 through March 1995-Continued

[Loads and standard errors are in pounds per day; <, less than; --, no data]

\begin{tabular}{|c|c|c|c|c|c|c|c|c|c|c|c|c|c|}
\hline \multirow[b]{2}{*}{ Site } & \multirow[b]{2}{*}{ Date } & \multicolumn{2}{|c|}{ Aluminum } & \multicolumn{2}{|c|}{ Iron } & \multicolumn{2}{|c|}{ Copper } & \multicolumn{2}{|c|}{ Cadmlum } & \multicolumn{2}{|c|}{ Manganese } & \multicolumn{2}{|c|}{ ZInc } \\
\hline & & Load & $\begin{array}{l}\text { Standard } \\
\text { error }\end{array}$ & Load & $\begin{array}{l}\text { Standard } \\
\text { error }\end{array}$ & Load & $\begin{array}{l}\text { Standard } \\
\text { error }\end{array}$ & Load & $\begin{array}{l}\text { Standard } \\
\text { error }\end{array}$ & Load & $\begin{array}{l}\text { Standard } \\
\text { error }\end{array}$ & Load & $\begin{array}{l}\text { Standard } \\
\text { error }\end{array}$ \\
\hline$\overline{\text { AR34.5 }}$ & $12 / 16 / 94$ & 211 & 21 & 431 & 54 & 20 & 3.5 & 0.1 & $<0.1$ & 50 & 4.5 & 13 & 1.0 \\
\hline AR31.0 & $12 / 16 / 94$ & 0.9 & -- & 1.3 & -- & 0.6 & - & $<0.1$ & -- & 1.2 & -- & 0.5 & -- \\
\hline AR34.5 & $12 / 17 / 94$ & 224 & 22 & 458 & 57 & 22 & 3.8 & 0.1 & $<0.1$ & 54 & 4.8 & 14 & 1.1 \\
\hline AR31.0 & $12 / 17 / 94$ & 0.9 & -- & 1.3 & -- & 0.6 & -- & $<0.1$ & - & 1.2 & -- & 0.5 & -- \\
\hline AR34.5 & $12 / 18 / 94$ & 224 & 22 & 458 & 57 & 22 & 3.8 & 0.1 & $<0.1$ & 54 & 4.8 & 14 & 1.1 \\
\hline AR31.0 & $12 / 18 / 94$ & 0.9 & -- & 1.3 & - & 0.6 & -- & $<0.1$ & - & 1.2 & -- & 0.5 & -- \\
\hline AR34.5 & $12 / 19 / 94$ & 211 & 21 & 431 & 54 & 20 & 3.5 & 0.1 & $<0.1$ & 50 & 4.5 & 13 & 1.0 \\
\hline AR31.0 & $12 / 19 / 94$ & 0.9 & -- & 1.3 & -- & 0.6 & -- & $<0.1$ & - & 1.2 & -- & 0.5 & -- \\
\hline AR34.5 & $12 / 20 / 94$ & 224 & 22 & 458 & 57 & 22 & 3.8 & 0.1 & $<0.1$ & 54 & 4.8 & 14 & 1.1 \\
\hline AR31.0 & $12 / 20 / 94$ & 0.9 & -- & 1.3 & -- & 0.6 & -- & $<0.1$ & - & 1.2 & -- & 0.5 & -- \\
\hline AR34.5 & $12 / 21 / 94$ & 211 & 21 & 431 & 54 & 20 & 3.5 & 0.1 & $<0.1$ & 50 & 4.5 & 13 & 1.0 \\
\hline AR31.0 & $12 / 21 / 94$ & 0.9 & -- & 1.3 & -- & 0.6 & - & $<0.1$ & - & 1.2 & -- & 0.5 & -- \\
\hline AR34.5 & $12 / 22 / 94$ & 211 & 21 & 431 & 54 & 20 & 3.5 & 0.1 & $<0.1$ & 50 & 4.5 & 13 & 1.0 \\
\hline AR31.0 & $12 / 22 / 94$ & 0.9 & -- & 1.3 & - & 0.6 & -- & $<0.1$ & -- & 1.2 & - & 0.5 & - \\
\hline AR34.5 & $12 / 23 / 94$ & 198 & 20 & 404 & 50 & 19 & 3.3 & 0.1 & $<0.1$ & 47 & 4.2 & 12 & 1.0 \\
\hline AR31.0 & $12 / 23 / 94$ & 0.9 & -- & 1.3 & -- & 0.6 & -- & $<0.1$ & -- & 1.2 & -- & 0.5 & -- \\
\hline AR34.5 & $12 / 24 / 94$ & 224 & 22 & 458 & 57 & 22 & 3.8 & 0.1 & $<0.1$ & 54 & 4.8 & 14 & 1.1 \\
\hline AR31.0 & $12 / 24 / 94$ & 0.9 & -- & 1.3 & -- & 0.6 & -- & $<0.1$ & - & 1.2 & -- & 0.5 & -- \\
\hline AR34.5 & $12 / 25 / 94$ & 211 & 21 & 431 & 54 & 20 & 3.5 & 0.1 & $<0.1$ & 50 & 4.5 & 13 & 1.0 \\
\hline AR31.0 & $12 / 25 / 94$ & 0.9 & - & 1.3 & -- & 0.6 & -- & $<0.1$ & - & 1.2 & - & 0.5 & -- \\
\hline AR34.5 & $12 / 26 / 94$ & 211 & 21 & 431 & 54 & 20 & 3.5 & 0.1 & $<0.1$ & 50 & 4.5 & 13 & 1.0 \\
\hline AR31.0 & $12 / 26 / 94$ & 0.9 & - & 1.3 & - & 0.6 & -- & $<0.1$ & -- & 1.2 & -- & 0.5 & -- \\
\hline AR34.5 & $12 / 27 / 94$ & 224 & 22 & 458 & 57 & 22 & 3.8 & 0.1 & $<0.1$ & 54 & 4.8 & 14 & 1.1 \\
\hline AR31.0 & $12 / 27 / 94$ & 0.9 & -- & 1.3 & -- & 0.6 & -- & $<0.1$ & - & 1.2 & -- & 0.5 & -- \\
\hline AR34.5 & $12 / 28 / 94$ & 211 & 21 & 431 & 54 & 20 & 3.5 & 0.1 & $<0.1$ & 50 & 4.5 & 13 & 1.0 \\
\hline AR31.0 & $12 / 28 / 94$ & 1.1 & - & 1.6 & -- & 0.7 & -- & $<0.1$ & - & 1.5 & -- & 0.6 & -- \\
\hline AR34.5 & $12 / 29 / 94$ & 224 & 22 & 458 & 57 & 22 & 3.8 & 0.1 & $<0.1$ & 54 & 4.8 & 14 & 1.1 \\
\hline AR31.0 & $12 / 29 / 94$ & 1.2 & - & 1.8 & -- & 0.7 & -- & $<0.1$ & - & 1.6 & -- & 0.7 & - \\
\hline AR34.5 & $12 / 30 / 94$ & 198 & 20 & 404 & 50 & 19 & 3.3 & 0.1 & $<0.1$ & 47 & 4.2 & 12 & 1.0 \\
\hline AR31.0 & $12 / 30 / 94$ & 1.2 & -- & 1.8 & -- & 0.7 & -- & $<0.1$ & -- & 1.6 & -- & 0.7 & -- \\
\hline AR34.5 & $12 / 31 / 94$ & 198 & 20 & 404 & 50 & 19 & 3.3 & 0.1 & $<0.1$ & 47 & 4.2 & 12 & 1.0 \\
\hline AR31.0 & $12 / 31 / 94$ & 1.2 & - & 1.8 & -- & 0.7 & -- & $<0.1$ & -- & 1.6 & -- & 0.7 & -- \\
\hline AR34.5 & $01 / 01 / 95$ & 172 & 17 & 350 & 44 & 17 & 2.9 & 0.1 & $<0.1$ & 41 & 3.6 & 11 & 0.8 \\
\hline AR31.0 & $01 / 01 / 95$ & 1.2 & -- & 1.8 & -- & 0.7 & -- & $<0.1$ & -- & 1.6 & -- & 0.7 & -- \\
\hline AR34.5 & $01 / 02 / 95$ & 172 & 17 & 350 & 44 & 17 & 2.9 & 0.1 & $<0.1$ & 41 & 3.6 & 11 & 0.8 \\
\hline AR31.0 & $01 / 02 / 95$ & 1.2 & -- & 1.8 & -- & 0.7 & -- & $<0.1$ & -- & 1.6 & -- & 0.7 & -- \\
\hline AR34.5 & $01 / 03 / 95$ & 172 & 17 & 350 & 44 & 17 & 2.9 & 0.1 & $<0.1$ & 41 & 3.6 & 11 & 0.8 \\
\hline AR31.0 & $01 / 03 / 95$ & 1.2 & -- & 1.8 & -- & 0.7 & -- & $<0.1$ & - & 1.6 & -- & 0.7 & - \\
\hline AR34.5 & $01 / 04 / 95$ & 185 & 18 & 377 & 47 & 18 & 3.1 & 0.1 & $<0.1$ & 44 & 3.9 & 12 & 0.9 \\
\hline AR31.0 & $01 / 04 / 95$ & 1.2 & -- & 1.8 & -- & 0.8 & -- & $<0.1$ & - & 1.7 & -- & 0.7 & - \\
\hline AR34.5 & $01 / 05 / 95$ & 185 & 18 & 377 & 47 & 18 & 3.1 & 0.1 & $<0.1$ & 44 & 3.9 & 12 & 0.9 \\
\hline AR31.0 & $01 / 05 / 95$ & 1.2 & -- & 1.9 & -- & 0.8 & -- & $<0.1$ & -- & 1.7 & -- & 0.7 & -- \\
\hline
\end{tabular}


Table 7. Estimated daily total-metal loads and standard errors for sites AR34.5 and AR31.0, April 1994 through March 1995-Continued

[Loads and standard errors are in pounds per day; $<$, less than;,-- no data]

\begin{tabular}{|c|c|c|c|c|c|c|c|c|c|c|c|c|c|}
\hline \multirow[b]{2}{*}{ Site } & \multirow[b]{2}{*}{ Date } & \multicolumn{2}{|c|}{ Aluminum } & \multicolumn{2}{|c|}{ Iron } & \multicolumn{2}{|c|}{ Copper } & \multicolumn{2}{|c|}{ Cadmium } & \multicolumn{2}{|c|}{ Manganese } & \multicolumn{2}{|c|}{ Zinc } \\
\hline & & Load & $\begin{array}{l}\text { Standard } \\
\text { error }\end{array}$ & Load & $\begin{array}{l}\text { Standard } \\
\text { error }\end{array}$ & Load & $\begin{array}{c}\text { Standard } \\
\text { error }\end{array}$ & Load & $\begin{array}{l}\text { Standard } \\
\text { error }\end{array}$ & Load & $\begin{array}{c}\text { Standard } \\
\text { error }\end{array}$ & Load & $\begin{array}{l}\text { Standard } \\
\text { orror }\end{array}$ \\
\hline$\overline{\mathrm{AR} 34.5}$ & $01 / 06 / 95$ & 185 & 18 & 377 & 47 & 18 & 3.1 & 0.1 & $<0.1$ & 44 & 3.9 & 12 & 0.9 \\
\hline AR31.0 & $01 / 06 / 95$ & 1.2 & -- & 1.9 & -- & 0.8 & -- & $<0.1$ & -- & 1.7 & -- & 0.7 & -- \\
\hline AR34.5 & $01 / 07 / 95$ & 185 & 18 & 377 & 47 & 18 & 3.1 & 0.1 & $<0.1$ & 44 & 3.9 & 12 & 0.9 \\
\hline AR31.0 & $01 / 07 / 95$ & 0.8 & 0.1 & 1.5 & 0.5 & 0.2 & $<0.1$ & $<0.1$ & $<0.1$ & 0.6 & 0.1 & 0.2 & $<0.1$ \\
\hline AR34.5 & $01 / 08 / 95$ & 185 & 18 & 377 & 47 & 18 & 3.1 & 0.1 & $<0.1$ & 44 & 3.9 & 12 & 0.9 \\
\hline AR31.0 & $01 / 08 / 95$ & 0.8 & 0.1 & 1.5 & 0.5 & 0.2 & $<0.1$ & $<0.1$ & $<0.1$ & 0.6 & 0.1 & 0.2 & $<0.1$ \\
\hline AR34.5 & $01 / 09 / 95$ & 198 & 20 & 404 & 50 & 19 & 3.3 & 0.1 & $<0.1$ & 47 & 4.2 & 12 & 1.0 \\
\hline AR31.0 & $01 / 09 / 95$ & 0.8 & 0.1 & 1.5 & 0.5 & 0.2 & $<0.1$ & $<0.1$ & $<0.1$ & 0.6 & 0.1 & 0.2 & $<0.1$ \\
\hline AR34.5 & $01 / 10 / 95$ & 198 & 20 & 404 & 50 & 19 & 3.3 & 0.1 & $<0.1$ & 47 & 4.2 & 12 & 1.0 \\
\hline AR31.0 & $01 / 10 / 95$ & 0.9 & 0.1 & 1.5 & 0.5 & 0.2 & $<0.1$ & $<0.1$ & $<0.1$ & 0.6 & 0.1 & 0.2 & $<0.1$ \\
\hline AR34.5 & $01 / 11 / 95$ & 198 & 20 & 404 & 50 & 19 & 3.3 & 0.1 & $<0.1$ & 47 & 4.2 & 12 & 1.0 \\
\hline AR31.0 & $01 / 11 / 95$ & 0.9 & 0.1 & 1.6 & 0.5 & 0.3 & $<0.1$ & $<0.1$ & $<0.1$ & 0.6 & 0.1 & 0.2 & 0.1 \\
\hline AR34.5 & $01 / 12 / 95$ & 211 & 21 & 431 & 54 & 20 & 3.5 & 0.1 & $<0.1$ & 50 & 4.5 & 13 & 1.0 \\
\hline AR31.0 & $01 / 12 / 95$ & 0.9 & 0.1 & 1.6 & 0.5 & 0.3 & $<0.1$ & $<0.1$ & $<0.1$ & 0.6 & 0.1 & 0.2 & 0.1 \\
\hline AR34.5 & $01 / 13 / 95$ & 211 & 21 & 431 & 54 & 20 & 3.5 & 0.1 & $<0.1$ & 50 & 4.5 & 13 & 1.0 \\
\hline AR31.0 & $01 / 13 / 95$ & 0.9 & 0.1 & 1.6 & 0.5 & 0.3 & $<0.1$ & $<0.1$ & $<0.1$ & 0.6 & 0.1 & 0.2 & 0.1 \\
\hline AR34.5 & $01 / 14 / 95$ & 211 & 21 & 431 & 54 & 20 & 3.5 & 0.1 & $<0.1$ & 50 & 4.5 & 13 & 1.0 \\
\hline AR31.0 & $01 / 14 / 95$ & 0.9 & 0.1 & 1.6 & 0.5 & 0.3 & $<0.1$ & $<0.1$ & $<0.1$ & 0.6 & 0.1 & 0.2 & 0.1 \\
\hline AR34.5 & $01 / 15 / 95$ & 211 & 21 & 431 & 54 & 20 & 3.5 & 0.1 & $<0.1$ & 50 & 4.5 & 13 & 1.0 \\
\hline AR31.0 & $01 / 15 / 95$ & 0.9 & 0.1 & 1.7 & 0.6 & 0.3 & $<0.1$ & $<0.1$ & $<0.1$ & 0.7 & 0.1 & 0.2 & 0.1 \\
\hline AR34.5 & $01 / 16 / 95$ & 211 & 21 & 431 & 54 & 20 & 3.5 & 0.1 & $<0.1$ & 50 & 4.5 & 13 & 1.0 \\
\hline AR31.0 & $01 / 16 / 95$ & 0.9 & 0.1 & 1.7 & 0.6 & 0.3 & $<0.1$ & $<0.1$ & $<0.1$ & 0.7 & 0.1 & 0.2 & 0.1 \\
\hline AR34.5 & $01 / 17 / 95$ & 224 & 22 & 458 & 57 & 22 & 3.8 & 0.1 & $<0.1$ & 54 & 4.8 & 14 & 1.1 \\
\hline AR31.0 & $01 / 17 / 95$ & 0.9 & 0.1 & 1.7 & 0.6 & 0.3 & $<0.1$ & $<0.1$ & $<0.1$ & 0.7 & 0.1 & 0.2 & 0.1 \\
\hline AR34.5 & $01 / 18 / 95$ & 224 & 22 & 458 & 57 & 22 & 3.8 & 0.1 & $<0.1$ & 54 & 4.8 & 14 & 1.1 \\
\hline AR31.0 & $01 / 18 / 95$ & 0.9 & 0.1 & 1.7 & 0.6 & 0.3 & $<0.1$ & $<0.1$ & $<0.1$ & 0.7 & 0.1 & 0.2 & 0.1 \\
\hline AR34.5 & $01 / 19 / 95$ & 224 & 22 & 458 & 57 & 22 & 3.8 & 0.1 & $<0.1$ & 54 & 4.8 & 14 & 1.1 \\
\hline AR31.0 & $01 / 19 / 95$ & 0.9 & 0.1 & 1.7 & 0.6 & 0.3 & $<0.1$ & $<0.1$ & $<0.1$ & 0.7 & 0.1 & 0.2 & 0.1 \\
\hline AR34.5 & $01 / 20 / 95$ & 224 & 22 & 458 & 57 & 22 & 3.8 & 0.1 & $<0.1$ & 54 & 4.8 & 14 & 1.1 \\
\hline AR31.0 & $01 / 20 / 95$ & 0.9 & 0.1 & 1.7 & 0.6 & 0.3 & $<0.1$ & $<0.1$ & $<0.1$ & 0.7 & 0.1 & 0.2 & 0.1 \\
\hline AR34.5 & $01 / 21 / 95$ & 224 & 22 & 458 & 57 & 22 & 3.8 & 0.1 & $<0.1$ & 54 & 4.8 & 14 & 1.1 \\
\hline AR31.0 & $01 / 21 / 95$ & 0.9 & 0.1 & 1.7 & 0.6 & 0.3 & $<0.1$ & $<0.1$ & $<0.1$ & 0.7 & 0.1 & 0.2 & 0.1 \\
\hline AR34.5 & $01 / 22 / 95$ & 238 & 24 & 485 & 61 & 23 & 4.0 & 0.1 & $<0.1$ & 57 & 5.0 & 15 & 1.2 \\
\hline AR31.0 & $01 / 22 / 95$ & 0.9 & 0.1 & 1.7 & 0.6 & 0.3 & $<0.1$ & $<0.1$ & $<0.1$ & 0.7 & 0.1 & 0.2 & 0.1 \\
\hline AR34.5 & $01 / 23 / 95$ & 238 & 24 & 485 & 61 & 23 & 4.0 & 0.1 & $<0.1$ & 57 & 5.0 & 15 & 1.2 \\
\hline AR31.0 & $01 / 23 / 95$ & 0.9 & 0.1 & 1.7 & 0.6 & 0.3 & $<0.1$ & $<0.1$ & $<0.1$ & 0.7 & 0.1 & 0.2 & 0.1 \\
\hline AR34.5 & $01 / 24 / 95$ & 238 & 24 & 485 & 61 & 23 & 4.0 & 0.1 & $<0.1$ & 57 & 5.0 & 15 & 1.2 \\
\hline AR31.0 & $01 / 24 / 95$ & 0.9 & 0.1 & 1.7 & 0.6 & 0.3 & $<0.1$ & $<0.1$ & $<0.1$ & 0.7 & 0.1 & 0.2 & 0.1 \\
\hline AR34.5 & $01 / 25 / 95$ & 238 & 24 & 485 & 61 & 23 & 4.0 & 0.1 & $<0.1$ & 57 & 5.0 & 15 & 1.2 \\
\hline AR31.0 & $01 / 25 / 95$ & 0.9 & 0.1 & 1.7 & 0.6 & 0.3 & $<0.1$ & $<0.1$ & $<0.1$ & 0.7 & 0.1 & 0.2 & 0.1 \\
\hline AR34.5 & $01 / 26 / 95$ & 251 & 25 & 512 & 64 & 24 & 4.2 & 0.1 & $<0.1$ & 60 & 5.3 & 16 & 1.2 \\
\hline AR31.0 & $01 / 26 / 95$ & 0.9 & 0.1 & 1.7 & 0.6 & 0.3 & $<0.1$ & $<0.1$ & $<0.1$ & 0.7 & 0.1 & 0.2 & 0.1 \\
\hline
\end{tabular}


Table 7. Estimated daily total-metal loads and standard errors for sites AR34.5 and AR31.0, April 1994 through March 1995-Continued

[Loads and standard errors are in pounds per day; <, less than; --, no data]

\begin{tabular}{|c|c|c|c|c|c|c|c|c|c|c|c|c|c|}
\hline \multirow[b]{2}{*}{ Site } & \multirow[b]{2}{*}{ Date } & \multicolumn{2}{|c|}{ Aluminum } & \multicolumn{2}{|c|}{ Iron } & \multicolumn{2}{|c|}{ Copper } & \multicolumn{2}{|c|}{ Cadmlum } & \multicolumn{2}{|c|}{ Manganese } & \multicolumn{2}{|c|}{ Zinc } \\
\hline & & Load & $\begin{array}{l}\text { Standard } \\
\text { error }\end{array}$ & Load & $\begin{array}{l}\text { Standard } \\
\text { error }\end{array}$ & Load & $\begin{array}{l}\text { Standard } \\
\text { error }\end{array}$ & Load & $\begin{array}{l}\text { Standard } \\
\text { error }\end{array}$ & Load & $\begin{array}{l}\text { Standard } \\
\text { error }\end{array}$ & Load & $\begin{array}{l}\text { Standard } \\
\text { error } \\
\end{array}$ \\
\hline$\overline{\text { AR34.5 }}$ & $01 / 27 / 95$ & 251 & 25 & 512 & 64 & 24 & 4.2 & 0.1 & $<0.1$ & 60 & 5.3 & 16 & 1.2 \\
\hline AR31.0 & $01 / 27 / 95$ & 0.9 & 0.1 & 1.7 & 0.6 & 0.3 & $<0.1$ & $<0.1$ & $<0.1$ & 0.7 & 0.1 & 0.2 & 0.1 \\
\hline AR34.5 & $01 / 28 / 95$ & 264 & 26 & 539 & 67 & 26 & 4.4 & 0.1 & $<0.1$ & 63 & 5.6 & 16 & 1.3 \\
\hline AR31.0 & $01 / 28 / 95$ & 0.9 & 0.1 & 1.7 & 0.6 & 0.3 & $<0.1$ & $<0.1$ & $<0.1$ & 0.7 & 0.1 & 0.2 & 0.1 \\
\hline AR34.5 & $01 / 29 / 95$ & 264 & 26 & 539 & 67 & 26 & 4.4 & 0.1 & $<0.1$ & 63 & 5.6 & 16 & 1.3 \\
\hline AR31.0 & $01 / 29 / 95$ & 0.9 & 0.1 & 1.7 & 0.6 & 0.3 & $<0.1$ & $<0.1$ & $<0.1$ & 0.7 & 0.1 & 0.2 & 0.1 \\
\hline AR34.5 & $01 / 30 / 95$ & 264 & 26 & 539 & 67 & 26 & 4.4 & 0.1 & $<0.1$ & 63 & 5.6 & 16 & 1.3 \\
\hline AR31.0 & $01 / 30 / 95$ & 0.9 & 0.1 & 1.7 & 0.6 & 0.3 & $<0.1$ & $<0.1$ & $<0.1$ & 0.7 & 0.1 & 0.2 & 0.1 \\
\hline AR34.5 & $01 / 31 / 95$ & 264 & 26 & 539 & 67 & 26 & 4.4 & 0.1 & $<0.1$ & 63 & 5.6 & 16 & 1.3 \\
\hline AR31.0 & $01 / 31 / 95$ & 0.9 & 0.1 & 1.7 & 0.6 & 0.3 & $<0.1$ & $<0.1$ & $<0.1$ & 0.7 & 0.1 & 0.2 & 0.1 \\
\hline AR34.5 & $02 / 01 / 95$ & 264 & 26 & 539 & 67 & 26 & 4.4 & 0.1 & $<0.1$ & 63 & 5.6 & 16 & 1.3 \\
\hline AR31.0 & $02 / 01 / 95$ & 0.9 & 0.1 & 1.7 & 0.6 & 0.3 & $<0.1$ & $<0.1$ & $<0.1$ & 0.7 & 0.1 & 0.2 & 0.1 \\
\hline AR34.5 & $02 / 02 / 95$ & 277 & 28 & 566 & 71 & 27 & 4.7 & 0.1 & $<0.1$ & 66 & 5.9 & 17 & 1.4 \\
\hline AR31.0 & $02 / 02 / 95$ & 0.9 & 0.1 & 1.7 & 0.6 & 0.3 & $<0.1$ & $<0.1$ & $<0.1$ & 0.7 & 0.1 & 0.2 & 0.1 \\
\hline AR34.5 & $02 / 03 / 95$ & 277 & 28 & 566 & 71 & 27 & 4.7 & 0.1 & $<0.1$ & 66 & 5.9 & 17 & 1.4 \\
\hline AR31.0 & $02 / 03 / 95$ & 0.9 & 0.1 & 1.7 & 0.6 & 0.3 & $<0.1$ & $<0.1$ & $<0.1$ & 0.7 & 0.1 & 0.2 & 0.1 \\
\hline AR34.5 & $02 / 04 / 95$ & 290 & 29 & 593 & 74 & 28 & 4.9 & 0.1 & $<0.1$ & 69 & 6.2 & 18 & 1.4 \\
\hline AR31.0 & $02 / 04 / 95$ & 0.9 & 0.1 & 1.7 & 0.6 & 0.3 & $<0.1$ & $<0.1$ & $<0.1$ & 0.7 & 0.1 & 0.2 & 0.1 \\
\hline AR34.5 & $02 / 05 / 95$ & 304 & 30 & 620 & 78 & 29 & 5.1 & 0.1 & $<0.1$ & 73 & 6.4 & 19 & 1.5 \\
\hline AR31.0 & $02 / 05 / 95$ & 0.9 & 0.1 & 1.7 & 0.6 & 0.3 & $<0.1$ & $<0.1$ & $<0.1$ & 0.7 & 0.1 & 0.2 & 0.1 \\
\hline AR34.5 & $02 / 06 / 95$ & 304 & 30 & 620 & 78 & 29 & 5.1 & 0.1 & $<0.1$ & 73 & 6.4 & 19 & 1.5 \\
\hline AR31.0 & $02 / 06 / 95$ & 1.0 & 0.1 & 1.7 & 0.6 & 0.3 & $<0.1$ & $<0.1$ & $<0.1$ & 0.7 & 0.1 & 0.2 & 0.1 \\
\hline AR34.5 & $02 / 07 / 95$ & 317 & 32 & 647 & 81 & 31 & 5.3 & 0.1 & $<0.1$ & 76 & 6.7 & 20 & 1.6 \\
\hline AR31.0 & $02 / 07 / 95$ & 1.0 & 0.1 . & 1.8 & 0.6 & 0.3 & $<0.1$ & $<0.1$ & $<0.1$ & 0.7 & 0.1 & 0.2 & 0.1 \\
\hline AR34.5 & $02 / 08 / 95$ & 317 & 32 & 647 & 81 & 31 & 5.3 & 0.1 & $<0.1$ & 76 & 6.7 & 20 & 1.6 \\
\hline AR31.0 & $02 / 08 / 95$ & 1.0 & 0.1 & 1.8 & 0.6 & 0.3 & $<0.1$ & $<0.1$ & $<0.1$ & 0.7 & 0.1 & 0.2 & 0.1 \\
\hline AR34.5 & $02 / 09 / 95$ & 330 & 33 & 674 & 84 & 32 & 5.5 & 0.1 & $<0.1$ & 79 & 7.0 & 21 & 1.6 \\
\hline AR31.0 & $02 / 09 / 95$ & 1.1 & 0.1 & 1.9 & 0.6 & 0.3 & $<0.1$ & $<0.1$ & $<0.1$ & 0.8 & 0.1 & 0.2 & 0.1 \\
\hline AR34.5 & $02 / 10 / 95$ & 330 & 33 & 674 & 84 & 32 & 5.5 & 0.1 & $<0.1$ & 79 & 7.0 & 21 & 1.6 \\
\hline AR31.0 & $02 / 10 / 95$ & 1.1 & 0.1 & 1.9 & 0.6 & 0.3 & $<0.1$ & $<0.1$ & $<0.1$ & 0.8 & 0.1 & 0.2 & 0.1 \\
\hline AR34.5 & $02 / 11 / 95$ & 330 & 33 & 674 & 84 & 32 & 5.5 & 0.1 & $<0.1$ & 79 & 7.0 & 21 & 1.6 \\
\hline AR31.0 & $02 / 11 / 95$ & 1.1 & 0.1 & 1.9 & 0.6 & 0.3 & $<0.1$ & $<0.1$ & $<0.1$ & 0.8 & 0.1 & 0.2 & 0.1 \\
\hline AR34.5 & $02 / 12 / 95$ & 330 & 33 & 674 & 84 & 32 & 5.5 & 0.1 & $<0.1$ & 79 & 7.0 & 21 & 1.6 \\
\hline AR31.0 & $02 / 12 / 95$ & 1.1 & 0.1 & 1.9 & 0.6 & 0.3 & $<0.1$ & $<0.1$ & $<0.1$ & 0.8 & 0.1 & 0.2 & 0.1 \\
\hline AR34.5 & $02 / 13 / 95$ & 343 & 34 & 701 & 88 & 33 & 5.8 & 0.1 & $<0.1$ & 82 & 7.3 & 21 & 1.7 \\
\hline AR31.0 & $02 / 13 / 95$ & 1.1 & 0.1 & 2.0 & 0.7 & 0.3 & $<0.1$ & $<0.1$ & $<0.1$ & 0.8 & 0.1 & 0.2 & 0.1 \\
\hline AR34.5 & $02 / 14 / 95$ & 343 & 34 & 701 & 88 & 33 & 5.8 & 0.1 & $<0.1$ & 82 & 7.3 & 21 & 1.7 \\
\hline AR31.0 & $02 / 14 / 95$ & 1.1 & 0.1 & 2.0 & 0.7 & 0.3 & $<0.1$ & $<0.1$ & $<0.1$ & 0.8 & 0.1 & 0.2 & 0.1 \\
\hline AR34.5 & $02 / 15 / 95$ & 356 & 36 & 728 & 91 & 34 & 6.0 & 0.1 & $<0.1$ & 85 & 7.6 & 22 & 1.8 \\
\hline AR31.0 & $02 / 15 / 95$ & 1.1 & 0.1 & 2.0 & 0.7 & 0.3 & $<0.1$ & $<0.1$ & $<0.1$ & 0.8 & 0.1 & 0.2 & 0.1 \\
\hline AR34.5 & $02 / 16 / 95$ & 356 & 36 & 728 & 91 & 34 & 6.0 & 0.1 & $<0.1$ & 85 & 7.6 & 22 & 1.8 \\
\hline AR31.0 & $02 / 16 / 95$ & 1.2 & 0.1 & 2.0 & 0.7 & 0.3 & $<0.1$ & $<0.1$ & $<0.1$ & 0.8 & 0.1 & 0.2 & 0.1 \\
\hline
\end{tabular}


Tabie 7. Estimated daily total-metal loads and standard errors for sites AR34.5 and AR31.0, April 1994 through March 1995-Continued

[Loads and standard errors are in pounds per day; <, less than; --, no data]

\begin{tabular}{|c|c|c|c|c|c|c|c|c|c|c|c|c|c|}
\hline \multirow[b]{2}{*}{ Site } & \multirow[b]{2}{*}{ Date } & \multicolumn{2}{|c|}{ Aluminum } & \multicolumn{2}{|c|}{ Iron } & \multicolumn{2}{|c|}{ Copper } & \multicolumn{2}{|c|}{ Cadmlum } & \multicolumn{2}{|c|}{ Manganese } & \multicolumn{2}{|c|}{$\bar{Z}$ Znc } \\
\hline & & Load & $\begin{array}{l}\text { Standard } \\
\text { error }\end{array}$ & Load & $\begin{array}{l}\text { Standard } \\
\text { error }\end{array}$ & Load & $\begin{array}{l}\text { Standard } \\
\text { error }\end{array}$ & Load & $\begin{array}{l}\text { Standard } \\
\text { error }\end{array}$ & Load & $\begin{array}{l}\text { Standard } \\
\text { error }\end{array}$ & Load & $\begin{array}{l}\text { Standard } \\
\text { error }\end{array}$ \\
\hline$\overline{\mathrm{AR} 34.5}$ & $02 / 17 / 95$ & 356 & 36 & 728 & 91 & 34 & 6.0 & $\overline{0.1}$ & $<0.1$ & 85 & 7.6 & 22 & 1.8 \\
\hline AR31.0 & $02 / 17 / 95$ & 1.2 & 0.1 & 2.1 & 0.7 & 0.3 & $<0.1$ & $<0.1$ & $<0.1$ & 0.8 & 0.1 & 0.2 & 0.1 \\
\hline AR34.5 & $02 / 18 / 95$ & 370 & 37 & 755 & 94 & 36 & 6.2 & 0.2 & $<0.1$ & 88 & 7.8 & 23 & 1.8 \\
\hline AR31.0 & $02 / 18 / 95$ & 1.2 & 0.1 & 2.1 & 0.7 & 0.3 & $<0.1$ & $<0.1$ & $<0.1$ & 0.8 & 0.1 & 0.2 & 0.1 \\
\hline AR34.5 & $02 / 19 / 95$ & 370 & 37 & 755 & 94 & 36 & 6.2 & 0.2 & $<0.1$ & 88 & 7.8 & 23 & 1.8 \\
\hline AR31.0 & $02 / 19 / 95$ & 1.2 & 0.1 & 2.1 & 0.7 & 0.3 & $<0.1$ & $<0.1$ & $<0.1$ & 0.8 & 0.1 & 0.2 & 0.1 \\
\hline AR34.5 & $02 / 20 / 95$ & 383 & 38 & 782 & 98 & 37 & 6.4 & 0.2 & $<0.1$ & 92 & 8.1 & 24 & 1.9 \\
\hline AR31.0 & $02 / 20 / 95$ & 1.2 & 0.1 & 2.1 & 0.7 & 0.3 & $<0.1$ & $<0.1$ & $<0.1$ & 0.8 & 0.1 & 0.2 & 0.1 \\
\hline AR34.5 & $02 / 21 / 95$ & 383 & 38 & 782 & 98 & 37 & 6.4 & 0.2 & $<0.1$ & 92 & 8.1 & 24 & 1.9 \\
\hline AR31.0 & $02 / 21 / 95$ & 1.2 & 0.1 & 2.1 & 0.7 & 0.3 & $<0.1$ & $<0.1$ & $<0.1$ & 0.8 & 0.1 & 0.2 & 0.1 \\
\hline AR34.5 & $02 / 22 / 95$ & 383 & 38 & 782 & 98 & 37 & 6.4 & 0.2 & $<0.1$ & 92 & 8.1 & 24 & 1.9 \\
\hline AR31.0 & $02 / 22 / 95$ & 1.2 & 0.1 & 2.1 & 0.7 & 0.3 & $<0.1$ & $<0.1$ & $<0.1$ & 0.9 & 0.1 & 0.2 & 0.1 \\
\hline AR34.5 & $02 / 23 / 95$ & 396 & 40 & 809 & 101 & 38 & 6.7 & 0.2 & $<0.1$ & 95 & 8.4 & 25 & 1.9 \\
\hline AR31.0 & $02 / 23 / 95$ & 1.2 & 0.1 & 2.1 & 0.7 & 0.3 & $<0.1$ & $<0.1$ & $<0.1$ & 0.9 & 0.1 & 0.2 & 0.1 \\
\hline AR34.5 & $02 / 24 / 95$ & 409 & 41 & 836 & 104 & 40 & 6.9 & 0.2 & $<0.1$ & 98 & 8.7 & 26 & 2.0 \\
\hline AR31.0 & $02 / 24 / 95$ & 1.2 & 0.1 & 2.2 & 0.7 & 0.4 & $<0.1$ & $<0.1$ & $<0.1$ & 0.9 & 0.1 & 0.2 & 0.1 \\
\hline AR34.5 & $02 / 25 / 95$ & 409 & 41 & 836 & 104 & 40 & 6.9 & 0.2 & $<0.1$ & 98 & 8.7 & 26 & 2.0 \\
\hline AR31.0 & $02 / 25 / 95$ & 1.2 & 0.1 & 2.2 & 0.7 & 0.4 & $<0.1$ & $<0.1$ & $<0.1$ & 0.9 & 0.1 & 0.2 & 0.1 \\
\hline AR34.5 & $02 / 26 / 95$ & 422 & 42 & 862 & 108 & 41 & 7.1 & 0.2 & $<0.1$ & 101 & 9.0 & 26 & 2.1 \\
\hline AR31.0 & $02 / 26 / 95$ & 1.3 & 0.1 & 2.3 & 0.8 & 0.4 & $<0.1$ & $<0.1$ & $<0.1$ & 0.9 & 0.1 & 0.2 & 0.1 \\
\hline AR34.5 & $02 / 27 / 95$ & 436 & 44 & 890 & 111 & 42 & 7.3 & 0.2 & $<0.1$ & 104 & 9.2 & 27 & 2.1 \\
\hline AR31.0 & $02 / 27 / 95$ & 1.3 & 0.1 & 2.3 & 0.8 & 0.4 & $<0.1$ & $<0.1$ & $<0.1$ & 0.9 & 0.1 & 0.2 & 0.1 \\
\hline AR34.5 & $02 / 28 / 95$ & 449 & 45 & 916 & 114 & 43 & 7.5 & 0.2 & $<0.1$ & 107 & 9.5 & 28 & 2.2 \\
\hline AR31.0 & $02 / 28 / 95$ & 1.3 & 0.1 & 2.3 & 0.8 & 0.4 & $<0.1$ & $<0.1$ & $<0.1$ & 0.9 & 0.1 & 0.2 & 0.1 \\
\hline AR34.5 & $03 / 01 / 95$ & 462 & 46 & 943 & 118 & 45 & 7.8 & 0.2 & $<0.1$ & 110 & 9.8 & 29 & 2.3 \\
\hline AR31.0 & $03 / 01 / 95$ & 1.3 & 0.1 & 2.3 & 0.8 & 0.4 & $<0.1$ & $<0.1$ & $<0.1$ & 0.9 & 0.1 & 0.2 & 0.1 \\
\hline AR34.5 & $03 / 02 / 95$ & 462 & 46 & 943 & 118 & 45 & 7.8 & 0.2 & $<0.1$ & 110 & 9.8 & 29 & 2.3 \\
\hline AR31.0 & $03 / 02 / 95$ & 1.3 & 0.1 & 2.3 & 0.8 & 0.4 & $<0.1$ & $<0.1$ & $<0.1$ & 0.9 & 0.1 & 0.2 & 0.1 \\
\hline AR34.5 & $03 / 03 / 95$ & 475 & 48 & 970 & 121 & 46 & 8.0 & 0.2 & $<0.1$ & 114 & 10.1 & 30 & 2.3 \\
\hline AR31.0 & $03 / 03 / 95$ & 1.3 & 0.1 & 2.3 & 0.8 & 0.4 & $<0.1$ & $<0.1$ & $<0.1$ & 0.9 & 0.1 & 0.2 & 0.1 \\
\hline AR34.5 & $03 / 04 / 95$ & 475 & 48 & 970 & 121 & 46 & 8.0 & 0.2 & $<0.1$ & 114 & 10.1 & 30 & 2.3 \\
\hline AR31.0 & $03 / 04 / 95$ & 1.3 & 0.1 & 2.3 & 0.8 & 0.4 & $<0.1$ & $<0.1$ & $<0.1$ & 0.9 & 0.1 & 0.2 & 0.1 \\
\hline AR34.5 & $03 / 05 / 95$ & 488 & 49 & 997 & 125 & 47 & 8.2 & 0.2 & $<0.1$ & 117 & 10.4 & 30 & 2.4 \\
\hline AR31.0 & $03 / 05 / 95$ & 1.3 & 0.1 & 2.3 & 0.8 & 0.4 & $<0.1$ & $<0.1$ & $<0.1$ & 0.9 & 0.1 & 0.2 & 0.1 \\
\hline AR34.5 & $03 / 06 / 95$ & 502 & 50 & 1,020 & 128 & 48 & 8.4 & 0.2 & $<0.1$ & 120 & 10.6 & 31 & 2.5 \\
\hline AR31.0 & $03 / 06 / 95$ & 1.3 & 0.1 & 2.3 & 0.8 & 0.4 & $<0.1$ & $<0.1$ & $<0.1$ & 0.9 & 0.1 & 0.2 & 0.1 \\
\hline AR34.5 & $03 / 07 / 95$ & 502 & 50 & 1,020 & 128 & 48 & 8.4 & 0.2 & $<0.1$ & 120 & 10.6 & 31 & 2.5 \\
\hline AR31.0 & $03 / 07 / 95$ & 1.3 & 0.1 & 2.4 & 0.8 & 0.4 & $<0.1$ & $<0.1$ & $<0.1$ & 1.0 & 0.1 & 0.2 & 0.1 \\
\hline AR34.5 & $03 / 08 / 95$ & 515 & 52 & 1,050 & 131 & 50 & 8.6 & 0.2 & $<0.1$ & 123 & 10.9 & 32 & 2.5 \\
\hline AR31.0 & $03 / 08 / 95$ & 1.3 & 0.1 & 2.4 & 0.8 & 0.4 & $<0.1$ & $<0.1$ & $<0.1$ & 1.0 & 0.1 & 0.2 & 0.1 \\
\hline AR34.5 & $03 / 09 / 95$ & 515 & 52 & 1,050 & 131 & 50 & 8.6 & 0.2 & $<0.1$ & 123 & 11 & 32 & 2.5 \\
\hline AR31.0 & $03 / 09 / 95$ & 1.4 & 0.1 & 2.4 & 0.8 & 0.4 & $<0.1$ & $<0.1$ & $<0.1$ & 1.0 & 0.1 & 0.3 & 0.1 \\
\hline
\end{tabular}


Table 7. Estimated daily total-metal loads and standard errors for sites AR34.5 and AR31.0, April 1994 through March 1995-Continued

[Loads and standard errors are in pounds per day; <, less than; --, no data]

\begin{tabular}{|c|c|c|c|c|c|c|c|c|c|c|c|c|c|}
\hline \multirow[b]{2}{*}{ Site } & \multirow[b]{2}{*}{ Date } & \multicolumn{2}{|c|}{ Aluminum } & \multicolumn{2}{|c|}{ Iron } & \multicolumn{2}{|c|}{ Copper } & \multicolumn{2}{|c|}{ Cadmium } & \multicolumn{2}{|c|}{ Manganese } & \multicolumn{2}{|c|}{ Żnc } \\
\hline & & Load & $\begin{array}{c}\text { Standard } \\
\text { error }\end{array}$ & Load & $\begin{array}{l}\text { Standard } \\
\text { error }\end{array}$ & Load & $\begin{array}{l}\text { Standard } \\
\text { error }\end{array}$ & Load & $\begin{array}{l}\text { Standard } \\
\text { error }\end{array}$ & Load & $\begin{array}{l}\text { Standard } \\
\text { error }\end{array}$ & Load & $\begin{array}{l}\text { Standard } \\
\text { error }\end{array}$ \\
\hline$\overline{\mathrm{AR} 34.5}$ & $03 / 10 / 95$ & 528 & 53 & 1,080 & 135 & 51 & 8.9 & 0.2 & $<0.1$ & 126 & 11 & 33 & 2.6 \\
\hline AR31.0 & $03 / 10 / 95$ & 1.4 & 0.1 & 2.4 & 0.8 & 0.4 & $<0.1$ & $<0.1$ & $<0.1$ & 1.0 & 0.1 & 0.3 & 0.1 \\
\hline AR34.5 & $03 / 11 / 95$ & 528 & 53 & 1,080 & 135 & 51 & 8.9 & 0.2 & $<0.1$ & 126 & 11 & 33 & 2.6 \\
\hline AR31.0 & $03 / 11 / 95$ & 1.4 & 0.1 & 2.4 & 0.8 & 0.4 & $<0.1$ & $<0.1$ & $<0.1$ & 1.0 & 0.1 & 0.3 & 0.1 \\
\hline AR34.5 & $03 / 12 / 95$ & 541 & 54 & 1,100 & 138 & 52 & 9.1 & 0.2 & $<0.1$ & 129 & 12 & 34 & 2.7 \\
\hline AR31.0 & $03 / 12 / 95$ & 1.4 & 0.1 & 2.5 & 0.8 & 0.4 & $<0.1$ & $<0.1$ & $<0.1$ & 1.0 & 0.1 & 0.3 & 0.1 \\
\hline AR34.5 & $03 / 13 / 95$ & 554 & 56 & 1,130 & 142 & 54 & 9.3 & 0.2 & $<0.1$ & 132 & 12 & 35 & 2.7 \\
\hline AR31.0 & $03 / 13 / 95$ & 1.4 & 0.1 & 2.5 & 0.8 & 0.4 & $<0.1$ & $<0.1$ & $<0.1$ & 1.0 & 0.1 & 0.3 & 0.1 \\
\hline AR34.5 & $03 / 14 / 95$ & 568 & 57 & 1,160 & 145 & 55 & 9.5 & 0.2 & $<0.1$ & 136 & 12 & 35 & 2.8 \\
\hline AR31.0 & $03 / 14 / 95$ & 1.4 & 0.1 & 2.5 & 0.8 & 0.4 & $<0.1$ & $<0.1$ & $<0.1$ & 1.0 & 0.1 & 0.3 & 0.1 \\
\hline AR34.5 & $03 / 15 / 95$ & 568 & 57 & 1,160 & 145 & 55 & 9.5 & 0.2 & $<0.1$ & 136 & 12 & 35 & 2.8 \\
\hline AR31.0 & $03 / 15 / 95$ & 1.4 & 0.1 & 2.5 & 0.8 & 0.4 & $<0.1$ & $<0.1$ & $<0.1$ & 1.0 & 0.1 & 0.3 & 0.1 \\
\hline AR34.5 & $03 / 16 / 95$ & 581 & 58 & 1,190 & 148 & 56 & 9.8 & 0.2 & $<0.1$ & 139 & 12 & 36 & 2.9 \\
\hline AR31.0 & $03 / 16 / 95$ & 1.4 & 0.1 & 2.5 & 0.8 & 0.4 & $<0.1$ & $<0.1$ & $<0.1$ & 1.0 & 0.1 & 0.3 & 0.1 \\
\hline AR34.5 & $03 / 17 / 95$ & 594 & 59 & 1,210 & 152 & 58 & $1<0.1$ & 0.2 & $<0.1$ & 142 & 13 & 37 & 2.9 \\
\hline AR31.0 & $03 / 17 / 95$ & 1.4 & 0.1 & 2.5 & 0.8 & 0.4 & $<0.1$ & $<0.1$ & $<0.1$ & 1.0 & 0.1 & 0.3 & 0.1 \\
\hline AR34.5 & $03 / 18 / 95$ & 594 & 59 & 1,210 & 152 & 58 & $1<0.1$ & 0.2 & $<0.1$ & 142 & 13 & 37 & 2.9 \\
\hline AR31.0 & $03 / 18 / 95$ & 1.5 & 0.1 & 2.6 & 0.9 & 0.4 & $<0.1$ & $<0.1$ & $<0.1$ & 1.1 & 0.1 & 0.3 & 0.1 \\
\hline AR34.5 & $03 / 19 / 95$ & 607 & 61 & 1,240 & 155 & 59 & 10 & 0.2 & $<0.1$ & 145 & 13 & 38 & 3.0 \\
\hline AR31.0 & $03 / 19 / 95$ & 1.6 & 0.1 & 2.8 & 1.0 & 0.5 & $<0.1$ & $<0.1$ & $<0.1$ & 1.2 & 0.1 & 0.3 & 0.1 \\
\hline AR34.5 & $03 / 20 / 95$ & 620 & 62 & 1,270 & 158 & 60 & 10 & 0.3 & $<0.1$ & 148 & 13 & 39 & 3.1 \\
\hline AR31.0 & $03 / 20 / 95$ & 1.6 & 0.1 & 2.8 & 1.0 & 0.5 & $<0.1$ & $<0.1$ & $<0.1$ & 1.2 & 0.1 & 0.3 & 0.1 \\
\hline AR34.5 & $03 / 21 / 95$ & 620 & 62 & 1,270 & 158 & 60 & 10 & 0.3 & $<0.1$ & 148 & 13 & 39 & 3.1 \\
\hline AR31.0 & $03 / 21 / 95$ & 1.6 & 0.1 & 2.9 & 1.0 & 0.5 & $<0.1$ & $<0.1$ & $<0.1$ & 1.2 & 0.1 & 0.3 & 0.1 \\
\hline AR34.5 & $03 / 22 / 95$ & 634 & 63 & 1,290 & 162 & 61 & 11 & 0.3 & $<0.1$ & 152 & 13 & 40 & 3.1 \\
\hline AR31.0 & $03 / 22 / 95$ & 1.6 & 0.1 & 2.8 & 1.0 & 0.5 & $<0.1$ & $<0.1$ & $<0.1$ & 1.2 & 0.1 & 0.3 & 0.1 \\
\hline AR34.5 & $03 / 23 / 95$ & 647 & 65 & 1,320 & 165 & 63 & 11 & 0.3 & $<0.1$ & 155 & 14 & 40 & 3.2 \\
\hline AR31.0 & $03 / 23 / 95$ & 1.6 & 0.1 & 2.8 & 1.0 & 0.5 & $<0.1$ & $<0.1$ & $<0.1$ & 1.2 & 0.1 & 0.3 & 0.1 \\
\hline AR34.5 & $03 / 24 / 95$ & 647 & 65 & 1,320 & 165 & 63 & 11 & 0.3 & $<0.1$ & 155 & 14 & 40 & 3.2 \\
\hline AR31.0 & $03 / 24 / 95$ & 1.6 & 0.1 & 2.8 & 0.9 & 0.5 & $<0.1$ & $<0.1$ & $<0.1$ & 1.1 & 0.1 & 0.3 & 0.1 \\
\hline AR34.5 & $03 / 25 / 95$ & 726 & 73 & 1,480 & 185 & 70 & 12 & 0.3 & $<0.1$ & 174 & 15 & 45 & 3.6 \\
\hline AR31.0 & $03 / 25 / 95$ & 1.5 & 0.1 & 2.6 & 0.9 & 0.4 & $<0.1$ & $<0.1$ & $<0.1$ & 1.1 & 0.1 & 0.3 & 0.1 \\
\hline AR34.5 & $03 / 26 / 95$ & 766 & 77 & 1,560 & 195 & 74 & 13 & 0.3 & $<0.1$ & 183 & 16 & 48 & 3.8 \\
\hline AR31.0 & $03 / 26 / 95$ & 1.4 & 0.1 & 2.5 & 0.8 & 0.4 & $<0.1$ & $<0.1$ & $<0.1$ & 1.0 & 0.1 & 0.3 & 0.1 \\
\hline AR34.5 & $03 / 27 / 95$ & 871 & 87 & 1,780 & 222 & 84 & 15 & 0.4 & $<0.1$ & 208 & 18 & 54 & 4.3 \\
\hline AR31.0 & $03 / 27 / 95$ & 1.4 & 0.1 & 2.5 & 0.8 & 0.4 & $<0.1$ & $<0.1$ & $<0.1$ & 1.0 & 0.1 & 0.3 & 0.1 \\
\hline AR34.5 & $03 / 28 / 95$ & 1,070 & 107 & 2,180 & 273 & 104 & 18 & 0.4 & $<0.1$ & 256 & 23 & 67 & 5.3 \\
\hline AR31.0 & $03 / 28 / 95$ & 1.4 & 0.1 & 2.5 & 0.8 & 0.4 & $<0.1$ & $<0.1$ & $<0.1$ & 1.0 & 0.1 & 0.3 & 0.1 \\
\hline AR34.5 & $03 / 29 / 95$ & 911 & 91 & 1,860 & 232 & 88 & 15 & 0.4 & $<0.1$ & 218 & 19 & 57 & 4.5 \\
\hline AR31.0 & $03 / 29 / 95$ & 1.4 & 0.1 & 2.4 & 0.8 & 0.4 & $<0.1$ & $<0.1$ & $<0.1$ & 1.0 & 0.1 & 0.3 & 0.1 \\
\hline AR34.5 & $03 / 30 / 95$ & 1,120 & 112 & 2,290 & 286 & 109 & 19 & 0.5 & $<0.1$ & 268 & 24 & 70 & 5.5 \\
\hline AR31.0 & $03 / 30 / 95$ & 1.4 & 0.1 & 2.4 & 0.8 & 0.4 & $<0.1$ & $<0.1$ & $<0.1$ & 1.0 & 0.1 & 0.3 & 0.1 \\
\hline AR34.5 & $03 / 31 / 95$ & 1,080 & 108 & 2,210 & 276 & 105 & 18 & 0.4 & $<0.1$ & 259 & 23 & 68 & 5.3 \\
\hline AR31.0 & $03 / 31 / 95$ & 1.4 & 0.1 & 2.4 & 0.8 & 0.4 & $<0.1$ & $<0.1$ & $<0.1$ & 1.0 & 0.1 & 0.2 & 0.1 \\
\hline
\end{tabular}

